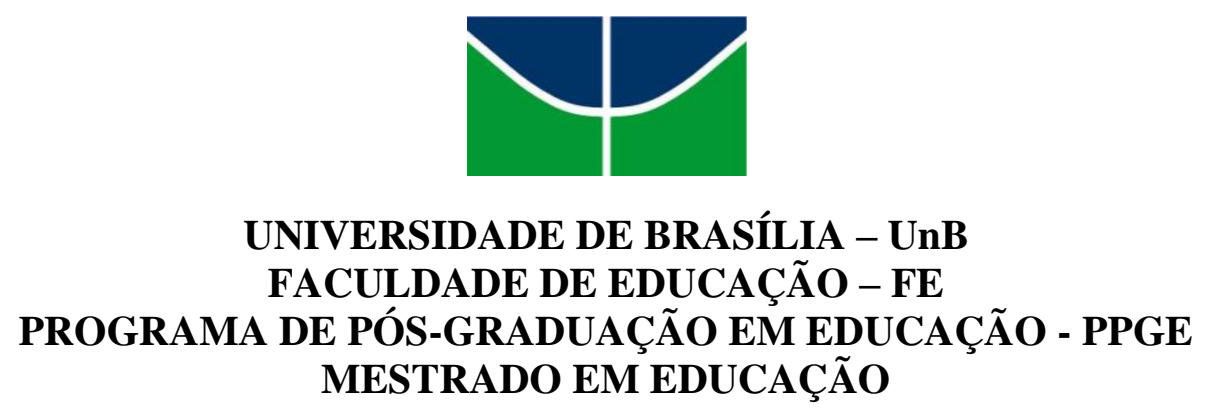

THALITA ANDRESSA BARBOSA PAES LANDIM

O Pedagogo formado na UnB e a sua atuação na Educação Inclusiva

Brasília - DF

2016 
THALITA ANDRESSA BARBOSA PAES LANDIM

\section{O Pedagogo formado na UnB e a sua atuação na Educação Inclusiva}

Dissertação de Mestrado apresentada ao Programa de Pós-Graduação da Faculdade de Educação da Universidade de Brasília, como um dos requisitos para a obtenção do título de Mestre em Educação, sob a orientação da Professora Doutora Ilma Passos Alencastro Veiga.

Brasília - DF

2016 


\title{
O Pedagogo formado na UnB e a sua atuação na Educação Inclusiva
}

\begin{abstract}
Dissertação de Mestrado apresentada ao Programa de Pós-Graduação da Faculdade de Educação da Universidade de Brasília, como um dos requisitos para a obtenção do título de Mestre em Educação, sob a orientação da Professora Doutora Ilma Passos Alencastro Veiga.
\end{abstract}

\section{Banca Examinadora}

Prof $^{\mathrm{a}}$. Dr$^{\mathrm{a}}$. Ilma Passos Alencastro Veiga (Orientadora - FE/UnB)

Prof $^{a}$. Dr ${ }^{\mathrm{a}}$. Cleide Maria Quevedo Quixadá Viana (Examinadora - FE/UnB)

Prof $^{\mathrm{a}}$. Dr ${ }^{\mathrm{a}}$. Pura Lúcia Oliver Martins (Examinadora Externa - PUC/PR)

Prof $^{\mathrm{a}}$. Dr ${ }^{\mathrm{a}}$. Liliane Campos Machado (Examinadora suplente - FE/UnB)

Brasília, 29 de abril de 2016. 
Aos meus pais, Elina e Dalmo, que sempre me apoiaram e incentivaram a lutar pelos meus sonhos e ideais. A minha irmã Lorena pela paciência e companheirismo. Amo vocês do fundo do coração! 


\section{Agradecimento}

Agradeço e louvo primeiramente a Deus, por ter permitido esta oportunidade de estudo em minha vida. A Nossa Senhora que sempre desatou os nós certos nos momentos que eu mais precisei.

Agradeço aos meus pais Elina e Dalmo que me ensinaram desde criança que o conhecimento advindo do estudo e do nosso esforço pessoal ninguém é capaz de tirar. Tudo pode passar e acabar, mas o nosso conhecimento ninguém nós tira. Também agradeço a minha irmã Lorena por todos os "puxões de orelha", palavras de confiança e companheirismo.

Agradeço ao meu avô Landim que foi o primeiro a acreditar em meu potencial acadêmico e desde cedo me viu como Mestre. Agradeço a minha vó Teresinha, vó Maria e vô Mireiro pelo apoio e incentivo sempre.

Agradeço a minha orientadora, a querida professora Ilma Passos Alencastro Veiga por todo carinho, empenho, paciência, correções e incentivo. Sou grata a Deus por tê-la colocado como a pessoa certa para me orientar e me ensinar que eu sempre sou capaz de mais.

Agradeço a Secretaria de Educação pelo incentivo ao estudo. Também agradeço aos diretores do CEF 02 da Estrutural que sempre compreenderam as minhas necessidades de mestranda e sempre me apoiaram na construção deste trabalho.

Agradeço aos meus amigos do curso de pedagogia da UnB que foram os primeiros a abrir as portas para o Mestrado e mostrar que a nossa turma foi diferente. Já temos em nosso saldo três Mestres (sou a próxima!), um mestrando e uma doutoranda. Turma de ouro!

Enfim, agradeço a todos que me apoiaram e incentivaram nesse meu momento de conquista pessoal e concretização de um sonho.

Muito Obrigada! 
"Quem forma se forma e re-forma ao formar e quem é formado forma-se e forma ao ser formado".

(Paulo Freire) 


\section{Resumo}

A presente dissertação buscou compreender como a formação inicial ofertada pela Universidade de Brasília influência o trabalho do professor em sala de aula com estudantes em inclusão. Deste modo ela tem como objetivo principal compreender como o Pedagogo egresso do curso de pedagogia da UnB desenvolve sua prática pedagógica em escolas inclusivas nos anos iniciais do ensino fundamental. E possui como objetivos específicos: analisar o Projeto Acadêmico do curso de Pedagogia da UnB para a formação inicial do Pedagogo; analisar os fundamentos teóricometodológicos dos planos de ensino das disciplinas: "O Educando com Necessidades Educacionais Especiais" e "Aprendizagem e Desenvolvimento do PNEE" que delimitam a formação do Pedagogo que atuará nos anos iniciais do ensino fundamental inclusivo; analisar as práticas pedagógicas inclusivas desenvolvidas pelo professor em sala de aula, e analisar as percepções das crianças da escola inclusiva com relação a prática pedagógica do professor dos anos iniciais do ensino fundamental. Foi utilizado como metodologia a pesquisa qualitativa e os seus instrumentos como: análise documental, questionário, entrevista semiestruturada, observação de campo e grupo focal. Sendo este último realizado com os estudantes das escolas observadas. As escolas selecionadas estavam localizadas nas regiões administrativas da Ceilândia e Asa Norte. Os professores atuavam em turmas do quinto ano do Ensino Fundamental e ambos tinham em suas salas de aula estudantes em inclusão. Por intermédio da comparação das análises da legislação vigente sobre a Educação Especial e Inclusiva, análise da literatura acadêmica e do observado em sala de aula foi possível visualizar que existe uma falha entre a formação inicial e o vivenciado em sala de aula em classes inclusivas, ocasionando assim uma ruptura entre a teoria e a prática. As reflexões e sinalizações desta pesquisa busca contribuir para uma mudança na formação inicial, onde a teoria e a prática caminhem juntas.

Palavras chave: Formação inicial; curso de Pedagogia UnB; Educação Inclusiva. 


\begin{abstract}
The present research aims to understand how the early formation offered by Brasília University (Universidade de Brasília - UnB) leading the teacher works in the classroom with special needs students. Thus, it aims to know how the new pedagogue professionals, graduated at UnB, develop your pedagogic practices in inclusive schools in the early years of the elementary school. In this context, the specifics subjects in this project are: the analysis of the Academic Project from the UnB Pedagogy course to the initial pedagogue formation; analyze the theoretical-methodological from the teaching projects in these subjects: "the student with special educational needs" ( $O$ Educando com Necessidades Educacionais Especiais) e "The PNEE knowledge and Development" (Aprendizagem e Desenvolvimento do PNEE) who delimiting the Pedagogue formation who will act in the early years of the inclusive elementary school; analyze the inclusive pedagogic practices developed by the teacher in the classroom, and analyze the perceptions of the students from the early years of the basic educational. It was used as methodology the qualitative survey and theirs instruments, like: documental analysis, questionnaires, half structured interviews, field observational and a focus group. Being the last one realized with the students from the observed schools. The selected schools were located in the administrative regions from Ceilândia and Asa Norte. The teachers worked in fifth grade class from the basic educational, and the both have in their classrooms special needs students. With the comparison between the analysis of the actual legislation about the Special and Inclusive Education, the academic literature analysis and the classroom observation was possible to visualized the existence of a failure between the beginning formation and what is experiencing in the inclusive special classes, promoting a rupture between theory and practice. The reflections and signs of this research seek to contribute for a change in the early formation, where the theory and practice can walk together.
\end{abstract}

Key-words: Early formation; UnB Pedagogy Course; Inclusive Education. 


\section{Lista de Figuras e Tabelas}

Figura 1 - Mapa Conceitual a respeito da Formação Inicial .............................. 15

Figura 2 - Mapa Conceitual Eixos da Educação Inclusiva ............................... 36

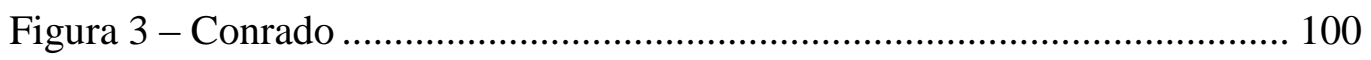

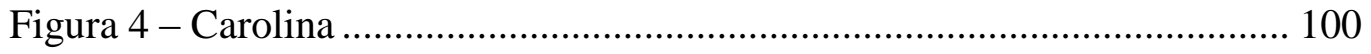

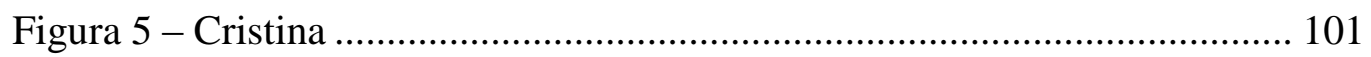

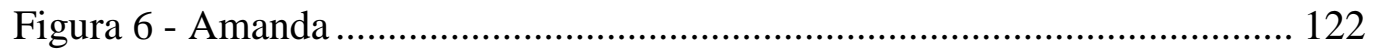

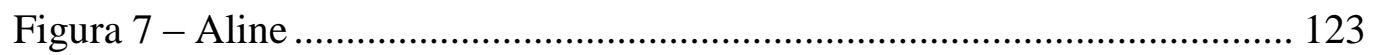

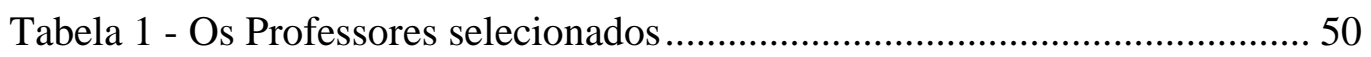

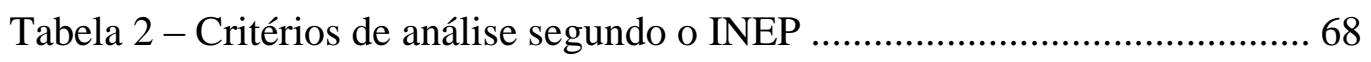

Tabela 3 - Agenda da Rotina................................................................... 115 


\section{Lista de Siglas e Abreviaturas}

A- Alfabetizado

AEE- Atendimento Educacional Especializado

ANA- Avaliação Nacional da Alfabetização

CDC- Convenção do direito da criança

CEE- Centro de Ensino Especial

CEPE- Conselho de Ensino, Pesquisa e Extensão

CF- Constituição Federal

DCN- Diretrizes Curriculares Nacionais

DF- Distrito Federal

DMU- Deficiências Múltiplas

EAPE- Escola de Aperfeiçoamento dos Profissionais da Educação

FE- Faculdade de Educação

GEPE- Grupo de estudo e/ou projeto de ensino/ pesquisa/ extensão

IDEB- Índice de Desenvolvimento da Educação Básica

IFB- Instituto Federal de Brasília

INEP- Instituto Nacional de Estudos e Pesquisas Educacionais Anísio Teixeira

LBI- Lei Brasileira de Inclusão

LDB- Lei de Diretrizes e Bases da Educação

MEC- Ministério da Educação

MTC- Métodos e técnicas

NDE- Núcleo Docente Estruturante

OAI- Orientação acadêmica integral

PAD

PCN- Parâmetros Curriculares Nacionais

PDCA- Profissão Docente, Currículo e Avaliação

PESPE- Projeto ou sub- projeto individual

PNE- Plano Nacional de Educação

PNEE- Portador de Necessidades Educacionais Especiais

PPP- Projeto Político Pedagógico

PS- Pré- silábico

RA- Região Administrativa

S- Silábico 
SAEB- Sistema de Avaliação da Educação Básica

SEDF- Secretaria de Educação do Distrito Federal

SPEPD- Sub- projeto individual de prática docente

TCC- Trabalho de conclusão de curso

TDAH- Transtorno do Déficit de Atenção e Hiperatividade

TEF- Teorias e Fundamentos

TFC- Trabalho de final de curso

TGD- Transtorno Global do Desenvolvimento

TIC- Tecnologias da informação e comunicação

UAB- Universidade Aberta do Brasil

UFJF- Universidade Federal de Juiz de Fora

UFRN- Universidade Federal do Rio Grande do Norte

UNB- Universidade de Brasília 


\section{SUMÁRIO}

Considerações Inicias 15

CAPÍTULO I - FUNDAMENTOS E PRINCÍPIOS DA EDUCAÇÃO

INCLUSIVA

1 Legislações sobre a Educação Inclusiva 20

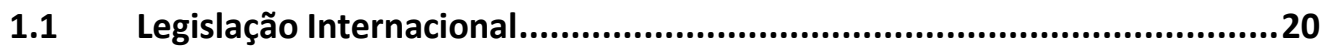

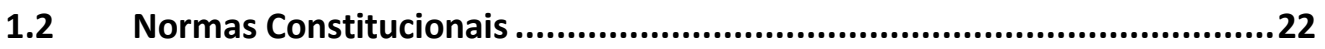

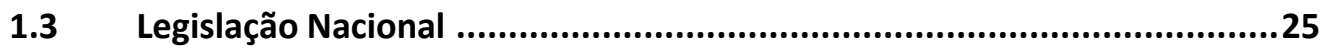

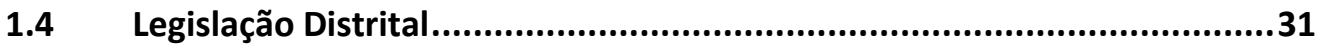

1.5 Educação Inclusiva: na perspectiva da literatura acadêmica ......................33

1.5.1 Formação - Bidocência .....................................................................................37

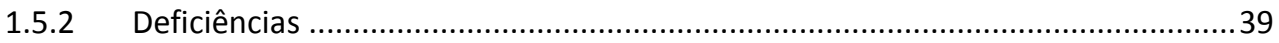

1.5.3 Transtorno Global do Desenvolvimento - TGD ...............................................41

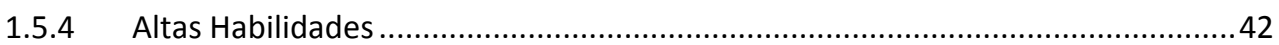

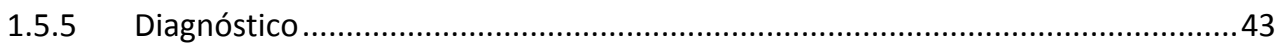

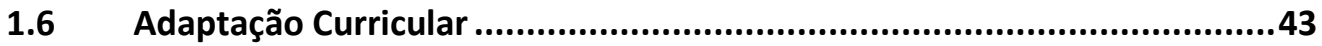

\section{CAPÍTULO II - TRAMAS METODOLÓGICAS: O CAMINHO}

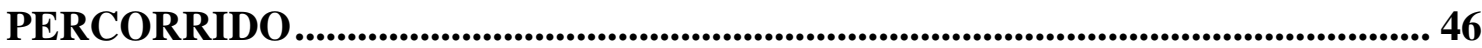

2 Fundamentos da pesquisa qualitativa ..................................................... 46

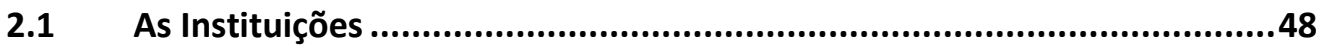

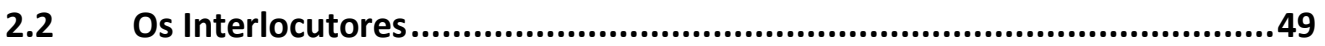

2.3 Os procedimentos de pesquisa/instrumentos......................................51

2.3.1 Análise Documental ..................................................................................51

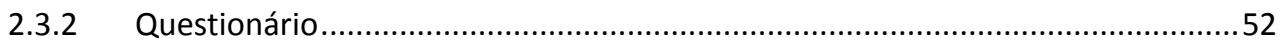

2.3.3 Observação Participante …………………………………………………......52

2.3.4 Projeto Político Pedagógico.................................................................................

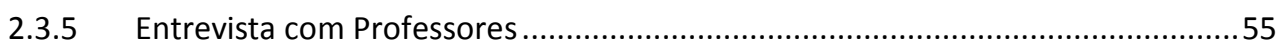

2.3.6 Grupo Focal com Crianças .........................................................................56

CAPÍTULO III - ANÁLISE DO PROJETO ACADÊMICO DO CURSO

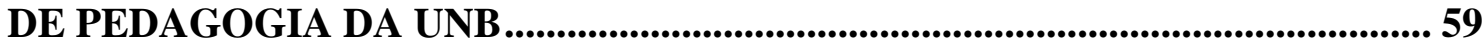


3 Curso de Pedagogia da Universidade de Brasília - UnB 59

3.1 Projeto Acadêmico do Curso de Pedagogia da UnB 59

3.1.1 Currículo do Curso de Pedagogia 63

3.2 Análise do Projeto Acadêmico do curso de Pedagogia da UnB de acordo com o Instrumento de Avaliação de Cursos de Graduação- presencial e a distância de agosto de 2015.

3.3 Análise das Ementas das Disciplinas sobre Educação Especial ..................77

3.3.1 O Educando com Necessidades Educacionais Especiais......................................77

3.3.2 Aprendizagem e Desenvolvimento do PNEE ................................................. 78

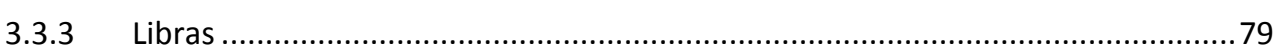

CAPÍTULO IV - ADENTRANDO AS ESCOLAS: ANÁLISE E

INTERPRETAÇÃO DA REALIDADE OBSERVADA ........................................ 80

$4 \quad$ A escola de Ceilândia.......................................................................................8 80

4.1 O Projeto Político Pedagógico da Escola ................................................80

4.2 Professor Carlos: formação e posicionamentos ....................................87

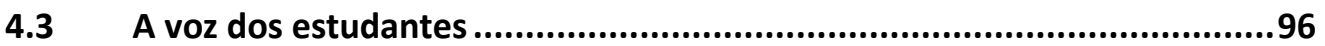

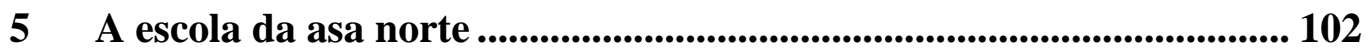

5.1 O Projeto Político Pedagógico da Escola ...........................................102

5.2 Professor Antônio: formação e posicionamentos.................................. 105

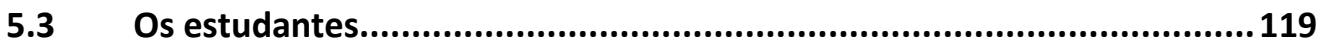

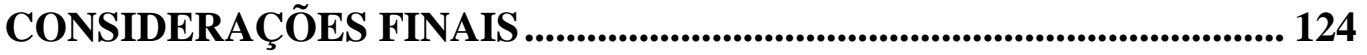

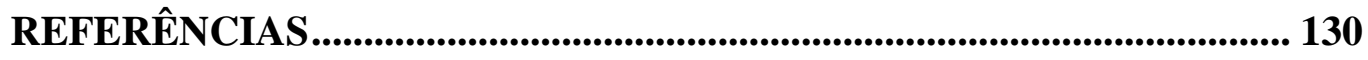

Apêndice I - Questionário ........................................................................... 137

Apêndice II - Termo de Consentimento Crianças............................................ 139

Apêndice III - Perguntas para a entrevista Semi - Estruturada.................. 140

Apêndice IV - Questões para o grupo focal com crianças .............................. 141

Anexo I - Fluxo Currícular do Curso de Pedagogia ........................................ 142

Anexo II - Relações de Espaços Curriculares Optativas no curso ............. 144 
Anexo III - Formação, Gestão e Orientação Acadêmica ................................ 146

Anexo IV - Ementa das Disciplinas ................................................................ 147

Anexo V- Turma da Mônica em Inclusão Social ............................................. 150 


\section{Considerações Inicias}

A presente dissertação tem como tema central a formação inicial do Pedagogo no curso de Pedagogia da Universidade de Brasília - UnB e a sua atuação nas séries iniciais do Ensino Fundamental em relação à Educação Inclusiva. A pesquisa terá como eixos estruturantes a legislação acerca da pessoa com deficiência; o Projeto Político Pedagógico PPP do curso de Pedagogia da Universidade de Brasília; o PPP das escolas observadas e a análise da prática do professor em sala de aula e do grupo focal realizado pelos estudantes.

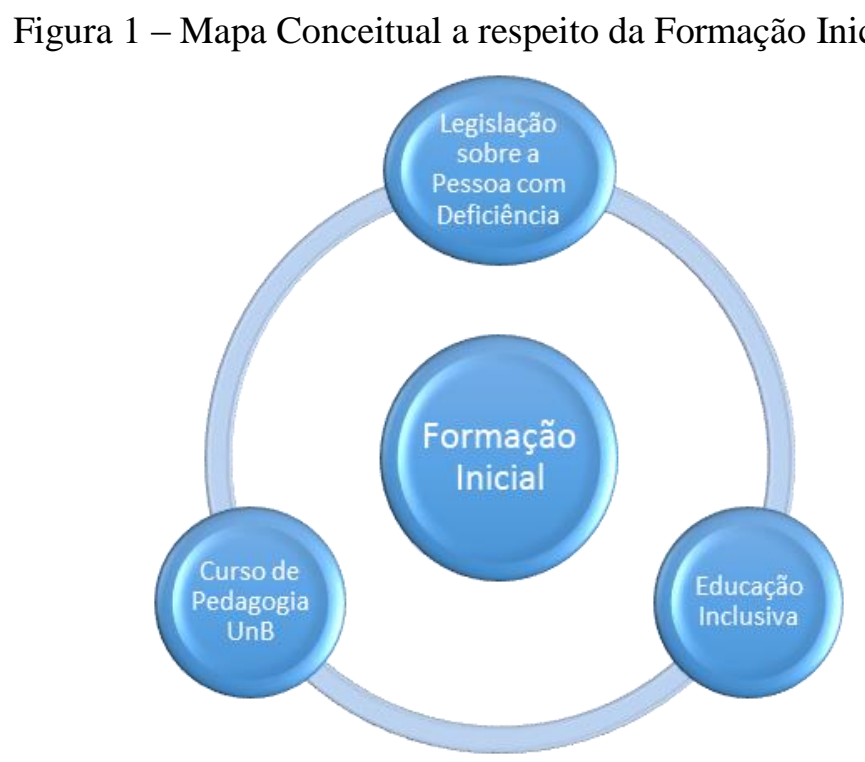

Fonte: Elaborado pela autora

O termo "pessoa com deficiência" será utilizado nesta dissertação, de acordo com a Convenção dos Direitos da Pessoa com Deficiência de 2006, ratificada no Brasil pelo Decreto $^{\circ}$ 186, de 2008, sob o caráter de Emenda Constitucional.

A partir da Declaração de Salamanca em 1994 começou a ser discutida no Brasil a inclusão de estudantes com deficiência nas salas de aula regulares. Desse modo, o Brasil para, atender essa necessidade, incluiu em suas legislações educacionais artigos que garantem o direito de acesso e permanência ao aluno com deficiência às/nas escolas; a sua inclusão em sala de aula regular; e o atendimento educacional especializado, entre outros direitos.

Algumas legislações que contemplaram essas necessidades educacionais foram a Constituição Federal - CF, de 1988; a Lei de Diretrizes e Bases da Educação - LDB; as Diretrizes Curriculares Nacionais - DCN para a Educação Básica na perspectiva da Educação Inclusiva; o Plano Nacional de Educação - PNE; e a Lei Brasileira de Inclusão - LBI. Esta 
última lei nasceu no ano de 2015 e foi promulgada como ganho e grande avanço de direitos para as pessoas com deficiência, pois essa legislação contempla grandes áreas que eram esquecidas como o direito à moradia, à saúde, ao trabalho, à educação, à previdência social, e à acessibilidade, entre outros. No Distrito Federal - DF, apenas em 2014, foi criado o documento Currículo em Movimento que garante que toda a escola pública do DF é inclusiva.

A Educação Inclusiva está sendo amplamente debatida na esfera universitária, na Educação Básica, no Ministério da Educação - MEC e nas Secretarias de Educação pelo Brasil, pois a sociedade clama por esse direito e os documentos oficiais acenam para a necessidade de uma educação de qualidade para todos sem distinção de raça, gênero, idade ou qualquer outro fator de discriminação. Tais debates destacam a necessidade de uma formação inicial que contemple com propriedade a área de Educação Especial e a importância da educação continuada.

A problemática de pesquisa apresentada neste trabalho surgiu do trabalho como servidora pública no cargo de Técnica de Assuntos Educacionais - Monitora ${ }^{1}$, na Secretaria de Educação do Distrito Federal - SEDF. O ingresso no cargo ocorreu em julho de 2012, sendo o primeiro local de trabalho o Centro de Ensino Especial do Guará. Em 2013, surgiu a necessidade de ficar em duas escolas: a Escola Classe 03 e o Centro de Ensino Fundamental 04, ambos do Guará. No ano de 2014, fui lotada no Centro de Ensino Fundamental 02 da Estrutural $^{2}$, onde permaneço até o presente momento. Trabalhei com diversos tipos de deficiência: intelectual, física e transtorno global do desenvolvimento.

Nesses locais de trabalho, observei e percebi que muitos professores que assumiam classes especiais e turmas inclusivas não estavam preparados para tais atividades. Muitos nunca tiveram contato com crianças com deficiência na sua formação inicial e não sabiam como se portar diante da situação de lidar com esses alunos. Para melhorar a qualidade do meu trabalho de Monitora, realizei um curso de aperfeiçoamento, a distância, em “Atividade Física para Pessoas com Necessidades Educacionais Especiais” realizado pela Universidade Federal de Juiz de Fora - UFJF, além de cursos ofertados pela Escola de Aperfeiçoamento dos profissionais da educação - Eape. A necessidade de realização do curso surgiu devido aos desafios enfrentados no dia a dia do trabalho com alunos com deficiência e à fragilidade ao trabalhar com os estudantes em classes de inclusão. De acordo com Veiga (2008, p.98), “a prática é o ponto de partida e dela emergem as questões, as necessidades e as

1 Técnica de Assuntos Educacionais - Monitor é um cargo de nível médio da SEDF criado para atender às necessidades físicas dos alunos com deficiência. Este cargo não exerce função pedagógica.

2 O CEF 02 da Estrutural pertence a regional de ensino do Guará. 
possibilidades". Dessa forma, após a realização do curso, com as discussões presentes nos fóruns e por meio do material fornecido pela UFJF, o trabalho com as crianças com deficiência ficou mais prazeroso, pois algumas dúvidas que possuía foram esclarecidas e o aprofundamento possibilitou compreender mais acerca de certos tipos de deficiências e dos procedimentos adequados a realizar com cada aluno.

Sempre estudei em colégio inclusivo e, do primeiro ao terceiro ano do Ensino Médio, tive em minha turma um colega com Hidrocefalia. Certa vez a direção da escola me perguntou se gostaria de ajudar esse aluno, principalmente com as atividades realizadas no caderno, pois ele tinha muita dificuldade em copiar e acompanhar o ritmo de escrita dos professores. Falei que ajudaria sim, sem nenhum problema. Esse estudante era bem participativo em sala. Os professores e os alunos interagiam com ele. Lembro que esse rapaz era apaixonado por Fórmula um, então, sempre que os outros estudantes da classe queriam conversar com ele, falavam desse assunto. Nos intervalos, ele nunca estava sozinho, sempre tinha um grupo que ficava com ele.

Formei-me em Pedagogia pela Universidade de Brasília, cursei as disciplinas: "Educando com Necessidades Educacionais Especiais" e "Aprendizagem e Desenvolvimento do Portador de Necessidades Educacionais Especiais - PNEE", mesmo assim, não me sentia preparada para trabalhar com a inclusão. Com o decorrer do tempo, surgiu a inquietação de que a formação inicial estava sendo falha, pois Pedagogos saídos da UnB, iguais a mim, tinham dificuldade de trabalhar com situações nas quais a inclusão estava presente. Neste ponto, foi necessário voltar à Academia para poder compreender esse fenômeno que estava acontecendo nas escolas públicas do DF. Segundo Veiga (2002, p. 84), “a formação tem como fundamento básico o trabalho como princípio educativo e a pesquisa como meio de produção de conhecimentos e intervenção na prática social e especificamente na prática pedagógica". A partir disso, a necessidade de pesquisar o tema em foco foi imprescindível para a intervenção na prática escolar vivenciada.

Diante do exposto, o problema de pesquisa deste trabalho consiste na seguinte indagação: Como o pedagogo egresso do curso de Pedagogia da Universidade de Brasília UnB desenvolve a sua prática pedagógica como professor da escola inclusiva de anos iniciais do ensino fundamental?

Outras questões específicas também são apresentadas, que são:

1. Qual a proposta do Projeto Acadêmico do curso de Pedagogia da UnB para a formação inicial do Pedagogo? 
2. Quais os fundamentos teórico-metodológicos dos planos de ensino das disciplinas " $\mathrm{O}$ Educando com Necessidades Educacionais Especiais" e "Aprendizagem e Desenvolvimento do PNEE" que delimitam a formação do Pedagogo que atuará nos anos iniciais do ensino fundamental inclusivo?

3. Como são desenvolvidas as práticas pedagógicas inclusivas pelo professor em sala de aula?

4. Como é percebida pelas crianças de escolas inclusivas a prática pedagógica do professor dos anos iniciais do ensino fundamental?

Diante desses questionamentos e das minhas inquietações, foram definidos os seguintes objetivos deste trabalho:

Objetivo Geral: Compreender como o Pedagogo egresso do curso de pedagogia da UnB desenvolve sua prática pedagógica em escolas inclusivas nos anos iniciais do ensino fundamental.

\section{Objetivos Específicos:}

1. Analisar a proposta do Projeto Acadêmico do curso de Pedagogia da UnB para a formação inicial do Pedagogo.

2. Analisar os fundamentos teórico-metodológicos dos planos de ensino das disciplinas: “ $\mathrm{O}$ Educando com Necessidades Educacionais Especiais" e “Aprendizagem e Desenvolvimento do PNEE", as quais delimitam a formação do Pedagogo que atuará nos anos iniciais do ensino fundamental inclusivo.

3. Analisar as práticas pedagógicas inclusivas desenvolvidas pelo professor em sala de aula.

4. Analisar as percepções das crianças da escola inclusiva em relação à prática pedagógica do professor dos anos iniciais do ensino fundamental.

Para alcançar os objetivos propostos neste trabalho, utilizei a pesquisa qualitativa como base de análise, assim como os seus instrumentos: análise documental, questionário, entrevista, observação e grupo focal. 


\section{CAPÍTULO I - FUNDAMENTOS E PRINCÍPIOS DA EDUCAÇÃO INCLUSIVA}

A Educação Inclusiva é parte integrante da modalidade de Educação Especial que foi inserida nos diversos níveis de educação escolar até Educação Superior.

A inclusão teve maior destaque nas discussões a respeito de Educação após a Declaração de Salamanca, em 1994. A partir de então, tornou-se evidente a necessidade de se implementar leis que garantem acesso, permanência e qualidade de todo e qualquer estudante que tenha interesse em estudar. Diante disso, o Brasil assinou o documento na Convenção dos direitos da Pessoa com Deficiência, no qual se compromete a adotar medidas que incluem todos os estudantes na Educação Básica. Tais medidas corroboram para a afirmação de que "a construção de uma sociedade inclusiva é um processo de fundamental importância para o desenvolvimento e a manutenção de um Estado democrático" (BRASIL, 2001 a, p. 20).

De acordo com as Diretrizes Nacionais para a Educação Especial na Educação Básica (2001 a, p. 28),

a política de inclusão de alunos que apresentam necessidades educacionais especiais na rede regular de ensino não consiste apenas na permanência física desses alunos junto aos demais educandos, mas representa a ousadia de rever concepções e paradigmas, bem como desenvolver o potencial dessas pessoas, respeitando suas diferenças e atendendo suas necessidades.

Esta colocação demonstra a necessidade de a escola se adequar ao aluno e não o inverso, o que caracteriza a necessidade de uma remodelação da estrutura escolar que temos hoje nas escolas de Educação Básica.

Conforme as Diretrizes Nacionais para a Educação Especial (2001a), a escola, ao construir espaços inclusivos, demonstra respeito e valorização aos alunos com deficiência e, desta forma, cumpre o que está prescrito na Constituição Federal de 1988, a qual garante que todas as pessoas têm direito à educação. Essa atitude inclusiva também caracteriza a função social da escola, que deve estar expressa no Projeto Político Pedagógico para que todos tenham consciência e que é dever de todos participar da inclusão.

Para as Diretrizes para a Educação Especial (2001a, p. 29), "não é o aluno que se amolda ou se adapta à escola, mas é ela que, consciente de sua função, coloca-se à disposição do aluno, tornando-se um espaço inclusivo". Dessa forma, é esperado que os alunos com deficiência consigam atingir os objetivos da educação em geral. 


\section{LEGISLAÇÕES SOBRE A EDUCAÇÃO INCLUSIVA}

\subsection{Legislação Internacional}

\section{Declaração dos direitos das pessoas deficientes - 1975}

Esta Declaração foi construída pelos Estados Membros das Nações Unidas com os objetivos de elevar os padrões de vida das pessoas com deficiência e garantir a elas emprego, e condições de progresso econômico e social. Anterior a ela, existiu a Declaração dos Direitos das Pessoas Mentalmente Retardadas, sendo assim, a inovação que essa nova legislação apresenta é o uso do termo "pessoa deficiente", o qual se refere a toda e qualquer pessoa incapaz de assegurar por si própria as necessidades de vida (ONU, 1975). Esse foi um primeiro passo para o início das discussões a respeito da Educação Inclusiva. Neste primeiro momento, percebe-se que era vista a deficiência e não o ser humano além dela.

São garantidos direitos referentes à dignidade humana, mesmo os fundamentais que as pessoas sem deficiência têm, como os direitos civis e políticos. A Declaração dos direitos das pessoas deficientes também prevê que devem ser adotadas medidas que busquem a capacitação das pessoas com deficiência para que elas se tornem "tão autoconfiantes quanto possível" (ONU, 1975, p. 2). Todas essas medidas visam à participação plena de todas as pessoas com deficiência na vida da sociedade, de forma que busquem cada vez mais a sua independência, levando sempre em consideração a intensidade de suas limitações.

\section{Declaração de Salamanca - 1994}

A Educação Inclusiva teve como marco a Declaração de Salamanca, em 1994. Esse documento proporcionou a educadores, profissionais da saúde, governantes e toda a população outra perspectiva a respeito da permanência e da qualidade do ensino ministrado a todos os estudantes. Por meio dessa declaração, foi proporcionada a mudança do paradigma da integração para o da inclusão.

De acordo com a Declaração de Salamanca, "as pessoas com necessidades educacionais especiais devem ter acesso às escolas comuns que deverão integrá-las numa pedagogia centralizada na criança, capaz de atender a essas necessidades" (BRASIL, 2001, p. 14). Desde essa nova concepção, os princípios de inclusão começaram a ser recepcionados no ambiente escolar. Assim, integração, nesta última citação, deve ser entendida como inclusão, pois, de acordo com a nota de rodapé apresentada no texto Diretrizes para a Educação Especial na Educação Básica (BRASIL, 2001a), a nomenclatura foi utilizada pela tradução 
literal do texto original de Salamanca; assim, o termo inclusão é o mais adequado para a realidade brasileira.

A Declaração de Salamanca enfatiza que existe a necessidade de que a escolarização dos estudantes com deficiência seja realizada em uma classe regular, onde devem ser proporcionadas a eles todas as condições de permanência e qualidade de ensino. $\mathrm{O}$ texto enfatiza que "a escolarização de crianças em escolas especiais - ou em classes especiais na escola regular - deveria ser uma exceção" (BRASIL, 2001, p. 16). No Brasil, apesar de já existirem algumas políticas que enfatizam a necessidade de matricular todos os estudantes em classes regulares, em alguns Estados e no Distrito Federal, ainda é recorrente encontrarmos classes especiais nas escolas regulares e nos Centros de Ensino Especial para alunos com limitações severas.

A inclusão de alunos "em classes comuns, exige que a escola regular se organize de forma a oferecer possibilidades objetivas de aprendizagem a todos os alunos, especialmente aqueles portadores de deficiências" (BRASIL, 2001, p. 18). Desse modo, deve ser responsabilidade da escola oferecer condições de acesso e aprendizagem a toda e qualquer criança que se dirija à unidade escolar em busca de ensino.

A Declaração de Salamanca destaca a necessidade de programas de desenvolvimento profissional para professores. Essas formações devem ocorrer tanto em serviço quanto nos ambientes acadêmicos. Assim, por meio do texto apresentado, é percebida a importância de uma formação permanente do professor, sempre visando às necessidades vivenciadas em sala de aula com seus alunos.

Convenção Interamericana para a Eliminação de todas as formas de discriminação contra as Pessoas Portadoras de Deficiência - 1999

Esta Convenção ficou mais conhecida como Convenção da Guatemala, país onde o documento foi assinado. Ela trata especificamente das formas de eliminar e prevenir qualquer forma de discriminação, diferenciação, preconceito e exclusão da pessoa com deficiência da sociedade.

Para conseguir alcançar os objetivos propostos nessa Convenção, os países que o assinaram (Argentina, Bolívia, Brasil, Chile, Colômbia, Costa Rica, Dominica, Equador, El Salvador, Guatemala, Haiti, Jamaica, México, Nicarágua, Panamá, Paraguai, Peru, República Dominicana, Uruguai e Venezuela) deveriam se comprometer em adotar algumas medidas, tais como: as de caráter legislativo, social, educacional e trabalhista; as eliminações de 
barreiras nos meios de transporte, nos prédios ou em qualquer outra instalação; e a eliminação dos obstáculos arquitetônicos.

No Brasil, em 2015, foi criada a Lei Brasileira de Inclusão - LBI, que atende o pedido de caráter legislativo dessa Convenção inclui as especificações sociais, educacionais e trabalhistas. No trabalho, as pessoas com deficiência devem ter colocação competitiva no mercado, em igualdade de oportunidade, tendo oferecimento de recursos de tecnologia assistiva e adaptação razoável. Na educação, nenhuma matrícula pode ser recusada por motivo de deficiência.

\section{Declaração Internacional de Montreal sobre Inclusão - 2001}

A Declaração de Montreal foi aprovada em 2001, após a Declaração Universal dos Direitos Humanos, que previa que todos os seres nascem livres e em igualdade de dignidade e direitos. Diante disso, foi observada a importância de se desenvolver um desenho inclusivo em todos os ambientes, produtos e serviços. Como resultado seria observada maior eficiência na economia no capital cultural e social. A responsabilidade pela promoção e pelo progresso dos desenhos inclusivos é de responsabilidade de todos os setores da sociedade. Além disso, devem ser "incorporados nos currículos de todos os programas de educação e treinamento" (2001, p. 2) a inclusão.

\subsection{Normas Constitucionais}

\section{Constituição Federal de 1988}

A Constituição Federal de 1988, em seu texto legal, pouco retrata os aspectos relativos à educação e traz apenas um inciso acerca da pessoa com deficiência: "art.208 IIIatendimento educacional especializado aos portadores de deficiência, preferencialmente na rede regular de ensino" (Brasil, 2013, p. 20). Esse aspecto retrata que o legislador, ao estabelecera matéria, não estava preparado para as mudanças que ocorreriam no âmbito educativo que se seguiram à promulgação da Constituição.

O atendimento educacional especializado é uma vitória para a pessoa com deficiência, mas, ao mesmo tempo, é uma incógnita, pois a legislação não deixa claro de que forma esse atendimento deve ser realizado; quais os profissionais que são capacitados para realizar esse atendimento; se podem e como devem ser feitas as adequações necessárias nos ambientes em que o aluno estuda. Após a CF, outras leis foram promulgadas, como a Lei de 
Diretrizes e Bases da Educação, a Lei Brasileira de Inclusão e as Diretrizes Curriculares Nacionais, as quais são responsáveis pela regulamentação do atendimento educacional especializado.

\section{Decreto Legislativo $n^{\circ} 186$, de 2008 - Convenção sobre os Direitos das pessoas} com Deficiência

O Decreto Legislativo $\mathrm{n}^{\circ} 186$, de 2008 , foi aprovado após a Convenção sobre os Direitos das Pessoas com Deficiência assinado em Nova Iorque, em março de 2007. Este é o único Decreto Legislativo que faz parte dos Direitos Internacionais e tem caráter de Emenda Constitucional. $\mathrm{O} \S 3^{\circ}$, artigo $5^{\circ}$ da Constituição Federal, incluído pela Emenda Constitucional $\mathrm{n}^{\mathrm{o}} 45$, de 2004, determina que "os tratados e convenções internacionais sobre os direitos humanos que forem aprovados, em cada Casa do Congresso Nacional, em dois turnos, por três quintos dos votos dos respectivos membros, serão equivalentes às emendas constitucionais" (BRASIL 2013, p. 22). Sendo assim, esse Decreto tem a mesma força que a Constituição Federal.

Com apenas dois parágrafos, o Decreto apresenta um extenso anexo de direitos referentes à pessoa com deficiência. Logo no preâmbulo, é apresentado ao leitor um conceito do que é deficiência:

Pessoas com deficiências são aquelas que têm impedimentos de longo prazo de natureza física, mental, intelectual ou sensorial, os quais, em interação com diversas barreiras, podem obstruir sua participação plena e efetiva na sociedade em igualdades de condições com as demais pessoas. (BRASIL, 2013, p. 26).

Esse conceito de deficiência será adotado nesta pesquisa como referência para a necessidade de eliminação de barreiras para a inclusão da pessoa com deficiência. Em todo o preâmbulo, é ressaltada a necessidade de igualdade de oportunidades, destacando também que a discriminação viola a dignidade do ser humano e reconhece que mulheres e meninas deficientes estão mais vulneráveis a riscos de violência, maus-tratos, abusos, descaso e negligência (Brasil, 2013).

Outro ponto que é apresentado no preâmbulo e merece atenção é o de

v) reconhecendo a importância da acessibilidade aos meios físicos, social, econômico e cultural, à saúde, à educação e à informação e comunicação, para possibilitar às pessoas com deficiência o pleno gozo de todos os direitos humanos e liberdades fundamentais (BRASIL, 2013, p. 23). 
Dessa forma, é ressaltada a necessidade de adequação de toda a sociedade para a inclusão total das pessoas com deficiência a esse meio. Esse ponto merece destaque, pois toda a sociedade deve estar preparada para recebê-las, não fazendo que elas se adequem ao lugar, mas com que o lugar se adeque à sua necessidade. Merece ênfase a situação na qual devem ser realizadas "adaptações razoáveis". O texto legal descreve que essas adaptações são:

\begin{abstract}
'Adaptação razoável' significa as modificações e os ajustes necessários e adequados que não acarretem ônus desproporcional ou indevido, quando requeridos em cada caso, a fim de assegurar que as pessoas com deficiência possam gozar ou exercer, em igualdade de oportunidade com as demais pessoas, todos os direitos humanos e liberdades fundamentais (BRASIL, 2013, p. 27).
\end{abstract}

Desse modo, as adaptações razoáveis visam facilitar os reparos arquitetônicos, mas não fica claro no Decreto $\mathrm{n}^{\circ} 186$ se o Governo Federal auxiliará de alguma maneira a custear essas reformas para o acesso da pessoa com deficiência a todos os espaços.

O Decreto Legislativo acerca do Direito das Pessoas com Deficiência nº 186/2008 reserva o artigo $8^{\circ}$ para falar a respeito da Conscientização. Esse artigo é de fundamental importância, pois demonstra, de maneira clara, que a pessoa com deficiência deve ser tratada com dignidade dentro e fora do seio familiar. Apresenta ao leitor que é necessário se “combater os estereótipos, preconceitos e práticas nocivas em relação a pessoas com deficiência, inclusive aquelas relacionados a sexo e idade, em todas as áreas da vida" (BRASIL, 2013, p. 30). Isso comprova que a pessoa com deficiência é um cidadão igual a qualquer outro e merece ser respeitado, assim como qualquer ser humano.

No que diz respeito à educação, o artigo $8^{\circ}$ ressalta que devem ser contínuas as campanhas de conscientização que favoreçam a solidariedade e o respeito para com a pessoa com deficiência, assim como é apresentado ao leitor um dos principais princípios da Educação Inclusiva:

b) fomentar em todos os níveis do sistema educacional, incluindo neles todas as crianças desde a tenra idade, uma atitude de respeito para com os direitos das pessoas com deficiência; [...] d) promover programas de formação sobre sensibilização a respeito das pessoas com deficiência e sobre os direitos das pessoas com deficiência (BRASIL, 2013, p. 31).

O artigo 24 é totalmente reservado à Educação. Nele é retratado que a pessoa com deficiência tem direito à educação sem discriminação baseado na igualdade de oportunidades, em todos os níveis e ao longo de toda a vida. É garantido o "pleno desenvolvimento do 
potencial humano e do senso de dignidade e autoestima", além do "máximo desenvolvimento possível da personalidade e dos talentos, assim como "a participação efetiva das pessoas com deficiência em uma sociedade livre" (BRASIL, 2013, p. 39).

Este Decreto afirma que os Estados Parte devem assegurar que as pessoas com deficiência "não sejam excluídas do sistema educacional geral sob alegação de deficiência" (BRASIL, 2013, p. 40), bem como devem oferecer um "ensino primário inclusivo, de qualidade e gratuito" (idem). Diante do exposto, é possível perceber que o legislador teve preocupação em deixar clara, no texto legal, a necessidade de uma Educação Inclusiva, na qual todos com e sem deficiência possam conviver harmoniosamente, sem nenhum tipo de preconceito ou discriminação, além de deixar expressas no texto formas de minimizar as barreiras físicas e espaciais, assim como as de comunicação e curriculares que impedem a livre circulação da pessoa com deficiência no espaço escolar.

Art.24. 4) A fim de contribuir para o exercício desse direito, os Estados Parte tomarão medidas apropriadas para empregar professores, inclusive professores com deficiência, habilitados para o ensino da língua de sinais e/ou braile, e para capacitar profissionais e equipes atuantes em todos os níveis de ensino. Essa capacitação incorporará a conscientização da deficiência e a utilização de modos, meios e formatos apropriados de comunicação aumentativa, e técnicas e materiais pedagógicos, como apoios para pessoas com deficiência. (BRASIL, 2013, p. 40-41).

Percebe-se no artigo 24 a preocupação do legislador, ao demostrar a necessidade de capacitar os profissionais que trabalharão com a pessoa com deficiência. Aperfeiçoando e capacitando quem educa e desenvolve esse sujeito, o trabalho pode tornar-se mais qualificado e eficaz.

\subsection{Legislação Nacional}

\section{Lei de Diretrizes e Bases da Educação Nacional}

A Educação Especial teve maior destaque na Lei de Diretrizes e Bases da Educação Nacional - LDB, Lei nº 9394/96, na qual essa modalidade de ensino ganhou um capítulo específico. Esse foi um grande avanço para a educação, porque confirma o que está elencado no artigo 208, inciso III, da Constituição Federal - CF, o qual declara que a educação é direito de todos e deve ser executada preferencialmente na rede regular de ensino.

Em seu parágrafo $1^{\circ}$, a lei descreve que "haverá, quando necessário, serviços de apoio especializado, na escola regular, para atender as peculiaridades da clientela de educação 
especial" (BRASIL, 2013, p. 124). Mais uma vez não fica claro qual é esse tipo de apoio especializado, como ele ocorrerá, nem em que circunstâncias ele se faz presente na escola.

A LDB garante ao estudante com deficiência um currículo adequado à suas necessidades, com métodos, técnicas e recursos educativos, assim como uma terminal idade específica para os que não puderem concluir todas as etapas do ensino fundamental e do médio. Exigem-se professores com especialização para o trabalho com esses alunos, sendo que esses docentes devem possuir "especialização adequada em nível médio ou superior, para atendimento especializado, bem como professores do ensino regular capacitados para a integração desses educandos nas classes comuns" (BRASIL, 2013, p. 124). Essa exigência de capacitação é fundamental para o aperfeiçoamento dos métodos e das técnicas adotados para lidar com as pessoas com deficiências.

A inclusão de alunos com deficiência nas classes regulares tem sido cada vez mais frequente. Assim, visando à qualidade do ensino e às necessidades dos educandos, foram criadas algumas legislações como as Diretrizes Curriculares Nacionais para a Educação Especial e a Lei Brasileira de Inclusão para amparar esse público.

Após leitura da Lei de Diretrizes e Bases da Educação, nenhuma citação acerca da Educação Inclusiva aparece. Esperava-se que, no capítulo onde se tratava de Educação Especial, fosse abordado um tópico. Assim como vem expresso na Convenção Internacional, esperava-se que a referência viesse em destaque em uma das principais Leis acerca da educação brasileira.

Lei Brasileira de Inclusão da Pessoa com Deficiência- Lei $n^{\circ}$ 13.146, de 6 de julho de 2015

A Lei Brasileira de Inclusão da pessoa com deficiência - LBI (Lei no 13.146, de 6 de julho de 2015) foi instituída com o objetivo de assegurar os direitos fundamentais, a igualdade de condições e o exercício das liberdades fundamentais de todas as pessoas com deficiência visando à inclusão social e à cidadania. Esta lei traz, em seus capítulos e artigos, tópicos essenciais para a garantia do exercício da cidadania pelas pessoas com deficiência.

O capítulo IV desta lei é reservado à Educação. O artigo 27 apresenta que

a educação constitui direito da pessoa com deficiência, assegurado sistema educacional inclusivo em todos os níveis e aprendizado ao longo de toda a vida, de forma a alcançar o máximo desenvolvimento possível de seus talentos e habilidades físicas, sensoriais, intelectuais e sociais, segundo suas características, interesses e necessidades de aprendizagem (BRASIL, 2015, p. 12). 
Desse modo, fica claro que o sistema educacional inclusivo deve estar presente em todos os níveis de ensino e aprendizado, permeando desde a Educação Infantil até os níveis mais avançados de estudo. Esse artigo é inovador, pois, na Constituição Federal de 1988 e na LDB 9394/94, apenas a Educação Especial deveria ocorrer em todas as esferas educativas.

O parágrafo único da Lei Brasileira de Inclusão explicita que "é dever do Estado, da família, da comunidade escolar e da sociedade assegurar educação de qualidade à pessoa com deficiência" (BRASIL, 2015, p. 8). Assim, todos os sujeitos apresentados na lei são incumbidos por assegurar uma educação de qualidade à pessoa com deficiência, sendo responsáveis por qualquer forma de violência, negligência ou discriminação que possa ocorrer nesse processo.

Outro aspecto inovador desta Lei está em seu artigo $28^{\circ}$, inciso III, onde o legislador deixa claro que no Projeto Pedagógico da escola deve estar claro, explícito e institucionalizado o atendimento educacional especializado, pois, assim, será possível garantir o pleno acesso do estudante ao currículo em condições de igualdade, com o objetivo de desenvolver a sua autonomia. Isso ainda não acontece nas escolas do Distrito Federal, mas, com a vigência da Lei, a partir de janeiro de 2016, todas as escolas devem realizar adaptações em seus Projetos Políticos Pedagógicos - PPPs para que essa exigência seja incorporada e possa, a partir de então, fazer parte, de fato, da vida cotidiana da escola.

A Lei Brasileira de Inclusão, em seu artigo $28^{\circ}$, inciso X, evidencia a necessidade da adoção de práticas pedagógicas inclusivas e que ela deve ser desenvolvida na formação inicial e continuada de professores (BRASIL, 2015). Esse aspecto é relevante para os cursos de graduação em Pedagogia e demais licenciaturas, pois, nesses espaços, é que precisam ocorrer as primeiras adoções de práticas pedagógicas inclusivas. Assim, os estudantes podem entrar em contato com elas e torná-las um hábito desde o primeiro momento na Universidade.

As mudanças na formação de professores advindas da LBI estão em seu artigo $28^{\circ}$, inciso XIV, onde são apresentados ao leitor os aspectos primordiais para a formação de professores em nível superior e de educação profissional. Nesse sentido, a inclusão dos conteúdos curriculares de temas acerca da pessoa com deficiência nos devidos campos do conhecimento se torna fundamental para a formação para a Educação Inclusiva.

\section{Plano Nacional de Educação: de 2001- 2010 e de 2014- 2024}

O Plano Nacional de Educação - PNE, Lei n 10.172, de janeiro de 2001, trouxe para o ideário da educação especial alguns conceitos que ainda não haviam sido debatidos 
pelas leis que discutem a educação, os quais se referem à Educação Inclusiva. Nesse primeiro momento, ainda existe uma perspectiva confusa do conceito de integração e inclusão. Diante disso, a primeira perspectiva é:

As tendências recentes dos sistemas de ensino são as seguintes: integração/inclusão do aluno com necessidades especiais no sistema regular de ensino e, se isto não for possível em função das necessidades do educando, realizar o atendimento em classes e escolas especializadas (BRASIL, 2013, p. 154).

O legislador não demonstra em seu texto nenhuma evidência de diferenciação entre integração e inclusão. Isso será tratado oportunamente.

A proposta e o grande avanço do Plano Nacional de Educação para a Década da Educação são a construção de uma escola Inclusiva que "garanta o atendimento à diversidade humana" (BRASIL, 2013, p. 154). O texto do PNE (2001 - 2010) apresenta ao leitor que a integração da pessoa com deficiência é uma diretriz constitucional que já está expressa no artigo 208 da Constituição Federal, mas, mesmo estando presente e explícita, ainda não apresentou e "produziu as mudanças necessárias na realidade escolar" (BRASIL, 2013, p. $155)$.

Assim, a proposta do legislador é que

o ambiente escolar como um todo deve ser sensibilizado para uma perfeita integração. Propõe-se uma escola integradora, inclusiva, aberta à diversidade dos alunos, no que a participação da comunidade é fator essencial. Quanto às escolas especiais, a política de inclusão as reorienta para prestarem apoio aos programas de integração.

Percebemos que a presença dos pais e da comunidade é fator essencial para que a inclusão possa ocorrer de fato nas escolas de todo o país. Tais apoios também podem ser conseguidos em parceria com a área de saúde e de assistência social, pois, dessa forma, o atendimento poderá ser ampliado.

Outro ponto de destaque trazido pela lei se refere à formação continuada dos professores que estão em exercício em salas de aula de inclusão. Esse ponto deve ser ressaltado, pois, para um trabalho de qualidade na educação especial, é necessária uma formação permanente, porque a todo o momento novas técnicas e tecnologias são aprimoradas para melhorar a qualidade do trabalho do professor.

No ano de 2014, foi elaborado o novo Plano Nacional de Educação 2014- 2024 com metas para diversas áreas. A Lei $\mathrm{n}^{\circ} 13.005 / 2014$ foi sancionada sem vetos e contempla $\mathrm{o}$ 
art.214 da Constituição Federal, que prevê a implantação do PNE, sendo que esse novo Plano terá uma duração decenal (BRASIL, 2014).

São estabelecidas algumas metas a serem cumpridas ao longo dos próximos dez anos e há uma específica para a Educação Especial. O legislador traz a meta número quatro com a seguinte redação:

Universalizar, para a população de quatro a dezessete anos com deficiência, transtornos globais do desenvolvimento e altas habilidades ou superdotação, o acesso à educação básica e o atendimento educacional especializado, preferencialmente na rede regular de ensino, com a garantia de sistema educacional inclusivo, de salas de recursos multifuncionais, classes, escolas ou serviços especializados, públicos ou conveniados (BRASIL, 2014, p. 55).

Também são apresentadas algumas estratégias de como implementar essa meta. A primeira delas diz respeito ao repasse do Fundo de Manutenção e Desenvolvimento da Educação Básica e de Valorização dos Profissionais da Educação (Fundeb) para os estudantes que realizam atendimento educacional especializado (BRASIL, 2014). Diferente das leis anteriores, as escolas receberiam um repasse diferenciado para poder atender com qualidade aos estudantes que fazem esse acompanhamento.

A segunda estratégia diz respeito à ampliação, no prazo de vigência do PNE, da universalização do atendimento escolar das crianças de zero a três anos. Outra estratégia que será responsável pela inclusão de todos os estudantes é a implementação de salas de recursos multifuncionais "para "fomentar a formação continuada de professores e professoras para o atendimento especializado nas escolas urbanas, do campo, indígenas e de comunidades quilombolas" (BRASIL, 2014, p. 55). Se forem implementadas com qualidade nessas comunidades as salas de recursos, isso será uma vitória para a Educação Inclusiva, pois povos que foram excluídos historicamente terão acesso a todo suporte necessário para que todos sejam incluídos. A formação continuada para os professores que atuam nessas comunidades é um ganho, porque terão capacidade para atuar com todos os estudantes de forma consciente.

Outra estratégia de destaque é "4.8. Garantir a oferta de educação inclusiva, vedada a exclusão do ensino regular sob alegação de deficiência e promovida a articulação pedagógica entre o ensino regular e o atendimento educacional especializado" (BRASIL, 2014, p. 56). Nesse artigo, o legislador reafirma a necessidade de a educação ocorrer na escola regular, sendo complementada com o auxílio do atendimento especializado e de ações pedagógicas para os alunos com deficiência que necessitarem de um currículo diferenciado. 
fomentar pesquisas voltadas para o desenvolvimento de metodologias, materiais didáticos, equipamentos e recursos de tecnologia assistiva, com vistas à promoção do ensino e da aprendizagem, bem como das condições de acessibilidade dos(as) estudantes com deficiência, transtornos globais do desenvolvimento e altas habilidades ou superdotação (BRASIL, 2014, p. 57).

O desenvolvimento de metodologias, materiais e equipamentos de tecnologia assistiva é importante para o desenvolvimento do trabalho do professor que atuará na educação inclusiva, pois proporcionará melhores condições de trabalho, assim como promoverá uma maior independência dos estudantes com deficiência. A tecnologia assistiva consiste em recursos e serviços que contribuem para auxiliar nas habilidades diárias das pessoas com deficiência, permitindo, assim, autonomia, independência, qualidade de vida e inclusão. Como recursos, tem-se desde uma simples bengala a brinquedos adaptados, computadores, softwares, equipamentos de comunicação alternativa, entre outros. Como serviço, são apresentadas fisioterapias, fonoaudiologia, psicologia, enfermagem, engenharia, arquitetura etc.

Um ganho importante para a Educação Inclusiva será a incorporação, nos cursos de licenciatura e nos cursos de formação de profissionais da educação, de "referenciais teóricos, das teorias de aprendizagem e dos processos de ensino- aprendizagem relacionados ao atendimento educacional de alunos com deficiência, transtornos globais do desenvolvimento e altas habilidades ou superdotação" (BRASIL, 2014, p. 58). Essa estratégia representará para a formação de professores e profissionais da educação um avanço na formação e na qualidade do ensino, pois todos sairão capacitados para atuar com estudantes deficientes dos cursos de licenciatura ou de pós-graduação.

\section{Estatuto da Criança e do Adolescente}

A Lei no 8.069, de 13 de julho de 1990, conhecida como Estatuto da Criança e do Adolescente, assim como a Constituição Federal, também é omissa em relação à pessoa com deficiência. Essa legislação se restringe a relatar que deve haver um atendimento educacional especializado e preferencialmente na rede regular de ensino aos portadores de deficiência. Ela não apresenta qualquer tipo de detalhamento acerca desse atendimento especializado (BRASIL, 2013).

Um significativo fator que a legislação apresenta em seu artigo $5^{\circ}$ é que "nenhuma criança ou adolescente será objeto de qualquer forma de negligência, discriminação, violência, crueldade e opressão, punido na forma da lei qualquer atentado, por ação ou omissão, aos seus direitos fundamentais" (BRASIL, 2001, p. 11). A partir desse artigo, 
observa-se a importância de tratar toda e qualquer criança de maneira igual. Caso isso não ocorra e a sociedade fique omissa a qualquer caso em que a criança tenha violado os seus direitos, todos os que participaram e estavam cientes dessa situação poderão ser punidos de acordo com a lei.

\subsection{Legislação Distrital}

\section{Secretaria de Educação do Distrito Federal - SEDF}

A modalidade Educação Especial foi concebida pela Secretaria de Educação do Distrito Federal na década de 1970. Nesse período, foram definidas ações que buscavam aperfeiçoar o atendimento dos estudantes com deficiência. De acordo com GDF (2014, p. 9), nesse período, "esse atendimento era concebido em uma proposta vinculada a princípios de individualização, segregação, normalização e integração de pessoas com deficiência" ainda não contemplando uma proposta de Educação Inclusiva.

Os alunos que apresentavam alguma deficiência nessa época eram encaminhados para instituições especializadas, também chamadas de "Centro de Ensino Especial" (GDF, 2014, p. 9), onde existiam classes especiais que tinham um número reduzido de alunos, com o objetivo de que o estudante fosse preparado para uma classe de integração. O Currículo em Movimento da Educação Básica (GDF, 2014) realiza uma análise desse período relatando que "permanecia-se com um regime de atendimento pautado pela segregação de alunos ao espaço pedagógico e social do coletivo da escola. A ineficiência desses processos gerou evasão, repetência ou ainda o retorno do estudante às instituições especializadas". Essa proposta fícou vigente nas escolas até a década de 1990.

Em meados de 1990, “o processo de integração começou a ser revisto com a perspectiva de inclusão" (GDF, 2014, p. 9). Nesse novo modelo adotado, "a instituição educacional deveria acolher o estudante e proporcionar-lhe a possibilidade de acesso à aprendizagem e a seu desenvolvimento global, buscando respeitar suas especificidades" (idem, grifos meus). Essa nova ótica traz claramente em seu texto traços marcantes da Educação Inclusiva, na qual o estudante deve ter o seu desenvolvimento completo e sempre respeitadas as suas necessidades particulares, mas ainda não foi nesse momento que a SEDF conseguiu avançar no processo inclusivo, pois ainda permanecia em uma ótica de integração e no "paradigma da normalização" (GDF, 2014, p. 10). Esse modelo faz referência a uma sociedade que tem como parâmetro um sujeito "normal", ou seja, sem deficiências ou 
qualquer outra característica que o diferencie dos demais. Os estudantes com deficiência estariam no desvio da curva da normalidade.

Apenas a partir dos anos 2000, a SEDF começou a organizar políticas e ações "fundamentadas no princípio de inclusão de todos os estudantes com necessidades educacionais especiais em classes comuns" (GDF, 2014, p. 10). A mudança para a educação inclusiva exigiu mudanças organizacionais e pedagógicas. Tais transformações podem ter sido de caráter físico ou curricular, visando tornar a escola pública mais inclusiva.

A inclusão ocorreu na SEDF "fundamentada na concepção de direitos humanos, que conjuga igualdade e diferença como valores indissociáveis” (GDF, 2014, p. 10). A partir da Lei $n^{\circ}$ 9394/96, foi possível, então, garantir “currículo, métodos, recursos e organização específica" (idem) para os estudantes com deficiência em classes de inclusão. Sendo assim, somente em 2003, a escola pública do DF adotou que

Fundamentado no paradigma da inclusão educacional, o Distrito Federal, por
meio da Lei no $3.218 / 2003$, estabeleceu que todas as escolas da rede pública
de ensino são inclusivas, assegurando, portanto, que as políticas públicas em
educação, bem como os desdobramentos empíricos advindos das mesmas
possam alcançar a população que requer atendimento especializado. Nesta
direção, o currículo, a avaliação, os métodos e as técnicas de ensino devem
ser aplicados também à educação especial, com o objetivo precípuo de
garantir o direito à educação. Assegurar esse direito implica ampliar a
discussão acerca de limites e possibilidades da escolarização desses
estudantes em escolas comuns, entendendo que neste momento histórico
ainda se configura a necessidade de escolas especializadas. (SEDF, 2014, p.
19-20).

Nessa nova perspectiva de inclusão, a Secretaria de Educação adotou como objetivo da Educação Inclusiva o de "ensinar a todos seus estudantes, sem distinção e com qualidade, favorecendo condições de acessibilidade, permanência e movendo seu processo de ensino-aprendizagem, bem como seu desenvolvimento global” (GDF, 2014, p. 11). Este documento ainda retrata que a sala de aula do ensino regular é o espaço real de inclusão, pois é nesse local que todos vão conviver contribuindo, assim, para um ambiente inclusivo e de crescimento.

É descrito no artigo 208, inciso III da Constituição Federal e no capítulo V, parágrafo primeiro da Lei de Diretrizes e Bases da Educação, que haverá atendimento educacional especializado para os estudantes com deficiência. Nessas duas leis, não é exemplificado o que seria esse atendimento especializado, mas o Currículo em Movimento da Educação Básica, no volume Educação Especial, GDF (2014), afirma que esse atendimento 
não deve ser realizado apenas pela sala de recursos, mas deve contemplar a estratégia pedagógica, assim como a organização didática e a curricular. Sendo assim, o currículo da Educação Inclusiva “deve ser dinâmico e flexível” (GDF, 2014, p. 11), capaz de proporcionar situações de aprendizagem.

A rede pública, em parceria com o Ministério da Educação - MEC, divulgou alguns projetos com o objetivo de garantir a inclusão escolar de todos os estudantes com deficiência, tais como: implementação de salas de recursos multifuncionais; programa de acessibilidade arquitetônica; parcerias para a formação continuada de professores para o atendimento especializado; ação interministerial na qual seriam monitoradas as pessoas com deficiência com idade de zero a 18 anos; núcleos de superdotação e altas habilidades e centros de apoio pedagógico a estudantes surdos; e acessibilidade ao programa do livros didático e paradidático (GDF, 2014). Poucas foram as ações que de fato entraram em vigor entre os anos de 2014 e 2015. Grande parte das escolas hoje possui salas de recursos multifuncionais para o atendimento especializado e uma parte dos cursos de formação são executados pela Escola de Aperfeiçoamento dos Profissionais da Educação - EAPE. Ainda falta incentivo do governo em executar obras para acessibilidade dos estudantes nas escolas e outras ações também não foram implementadas.

Um ponto relevante a se destacar é a necessidade de toda escola estar preparada para a inclusão do aluno com deficiência nesse ambiente. Alves (2012, p. 53) traz aspecto de que “o importante não é só capacitar o professor, mas capacitar toda equipe de funcionários desta escola, já que o indivíduo não estará apenas dentro de sala de aula”. Neste aspecto, a SEDF possui um grande aliado ao seu lado que é a inserção, em seu quadro profissional, de Técnicos de Assuntos Educacionais - Monitores. Esse cargo foi criado em 2009 e, desde a primeira convocação de servidores, as escolas estão amparadas por esses profissionais, que, teoricamente, estão capacitados para o exercício da profissão com os alunos com deficiência. O principal papel desse servidor é acompanhar o estudante em suas atividades diárias, mas nunca exercendo funções pedagógicas. Todos os profissionais da escola devem estar preparados para receber os alunos com deficiência.

\subsection{Educação Inclusiva: na perspectiva da literatura acadêmica}

Os primeiros traços de Educação Inclusiva apareceram a partir da década de 1990 com as Conferências Internacionais que tinham por objetivo defender uma educação igualitária para todos e a inserção do estudante com deficiência em escolas e classes regulares 
de ensino. Assim como já apresentado na parte de legislação, ratifica-se que a Declaração de Salamanca foi a principal Convenção Internacional que permitiu maior visibilidade para as necessidades de ensino das pessoas com deficiência.

O debate a respeito da Educação Inclusiva foi iniciado com o conceito de inclusão. Segundo Alves (2012, p. 19), "para que possamos incluir, devemos respeitar e querer desenvolver o indivíduo em todos os aspectos dentro do processo de aprendizagem". Esse primeiro conceito remete ao fato de que a inclusão busca desenvolver o indivíduo como um todo. Dessa forma, realizando uma pequena ligação com Vygotsky, o ser humano historicamente constituído deve estar situado histórica e culturalmente em uma sociedade e em uma cultura, para que possa desenvolver as suas competências e habilidades de forma completa. Para Alves (Idem), "qualquer indivíduo pode ser incluído, pois nós podemos e devemos envolvê-lo, implicá-lo, juntando-o a qualquer outro ser para somar o seu crescimento a ambos". Sendo assim, a inclusão é uma troca entre indivíduos na qual todos aprendem coletivamente por meio das trocas entre os pares. De acordo com Ainscow (2009), internacionalmente, a inclusão é vista não apenas como forma de servir aos estudantes com deficiência, mas como uma forma de acolher toda a diversidade de estudantes.

A inclusão tem a sua base primordial na escola e, sem parcerias com a família e a sociedade em geral, não pode ser concretizada. Alves (2012, p. 58) nos mostra que "tem que haver um trabalho com a sociedade, a comunidade e o educador para se fazer a inclusão social antes de tudo". Desse modo, a inclusão social procura enxergar o indivíduo na sua totalidade e busca compreender as suas necessidades na vida diária. Para Ainscow (2009, p. 13), "a falta de mudança organizacional [é] uma das maiores barreiras para a implementação das políticas de educação inclusiva". Essa ausência de transformação contraria o previsto no Decreto Legislativo $\mathrm{n}^{\circ} 186$ de 2008, o qual estimula que sejam realizadas adaptações razoáveis para atender a necessidade de todas as pessoas com e sem deficiência, para que, assim, exista o mínimo de barreiras possíveis que geram a exclusão da pessoa no ambiente escolar.

Dentro dessa nova concepção a respeito da educação de pessoas com deficiência, inicia-se uma alteração de paradigmas vivida pela Educação Especial, quando se sai do paradigma da integração e adentra-se ao paradigma da inclusão. Para Mantoan, a integração é o oposto da inclusão, porque, na inclusão, "todos os alunos, sem exceções, devem frequentar as salas de aula do ensino regular" (MANTOAN 2004, p. 40). Dessa forma, o paradigma da integração está relacionado à justaposição do ensino especial ao regular, entende-se, então, que a integração insere o aluno com deficiência no espaço escolar sem nenhuma preparação 
do ambiente para atendê-lo, enquanto na inclusão devem ser realizados ajustes físicos, espaciais e pedagógicos para que ele tenha qualidade e possa permanecer na escola.

Tal mudança paradigmática visa ao acesso de todas as pessoas com deficiência à educação regular, retira-as dos Centros de Ensino Especiais - CEE e concede a elas oportunidade de estarem incluídas em classes comuns. Isso também permite que todos os estudantes sejam percebidos como únicos em suas escolas e salas de aula e professores desenvolvam práticas pedagógicas singulares para cada estudante, com o objetivo de conseguir eliminar qualquer barreira que possa atrapalhar o seu processo de aprendizagem. A mudança de paradigma é importante para a Educação, pois propicia que todos os estudantes sejam vistos primeiramente como seres humanos, dotados de inteligência e capacidades, antes de serem percebidas as suas limitações. Tal transformação retira da pessoa a deficiência e a remete ao contexto social.

Concordando com Ainscow (2009), internacionalmente, a inclusão é definida de várias maneiras e não existe apenas uma perspectiva concebida. Desse modo, ela pode ser observada de seis formas principais: Inclusão referente à deficiência e à necessidade de educação especial; inclusão como resposta a exclusões disciplinares; inclusão que diz respeito a todos os grupos vulneráveis à exclusão; inclusão como forma de promover escola para todos; inclusão como educação para todos; e inclusão como uma abordagem de princípios à educação. Nessa ótica, a inclusão compreendida no Brasil diz respeito à inclusão referente à deficiência e às necessidades de educação especial. Existem alguns trabalhos para a eliminação da exclusão dos grupos vulneráveis, mas isso ainda não é compreendido como uma das formas de inclusão.

A definição que compreende que a inclusão se refere à deficiência e às necessidades de educação especial tem sido questionada, pois essa visão está focalizada na deficiência; e esquecem-se que, por trás da deficiência, existe um ser humano dotado de capacidades (AINSCOW, 2009). Existe um grande problema ao desvincular a inclusão das deficiências, pois "há o perigo do desvio da atenção da contínua segregação vivida por estudantes com deficiências" (Idem, p. 15). Diante do exposto, é necessário que exista um equilíbrio, para que nenhum dos pontos observados seja executado com exagero dentro das escolas, e sim para que os discentes, com e sem deficiência, se sintam parte do ambiente escolar, com direito à educação e tenham estímulo à aprendizagem.

Concordando com Miranda (2012, p. 127), “a inclusão se sustenta em três eixos (...), a escola, a prática pedagógica e a formação docente". 
Figura 2 - Mapa Conceitual Eixos da Educação Inclusiva

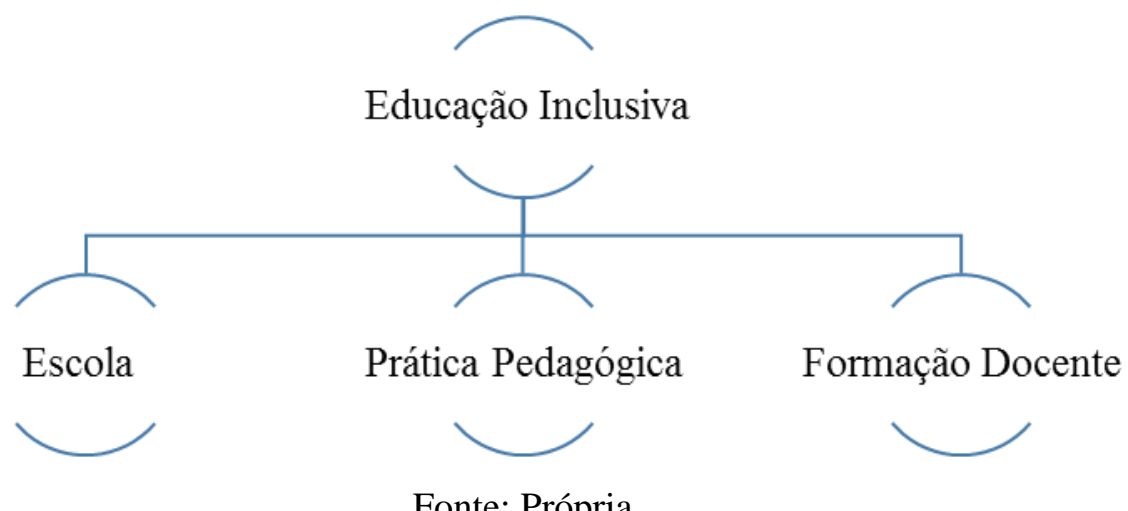

Fonte: Própria

Ainda segundo Miranda (idem), a escola é uma parte que constitui o todo social, ela é a responsável por apresentar aos estudantes os desdobramentos ocorridos na sociedade. Dessa forma, a escola também seria a incumbida da formação cultural.

Concebendo que a inclusão começa na escola, Mantoan (2004, p. 40) sugere que "as escolas inclusivas [proponham] um modo de organização do sistema educacional que considera as necessidades de todos os alunos e é estruturado em função dessas necessidades". Desse modo, é entendido que a escola deve ser adaptada para atender a esse aluno. Precisa, então, receber rampas de acesso, pisos táteis, banheiros adaptados, além de outras adaptações necessárias. A autora ainda levanta uma crítica que precisa ser analisada: “A inclusão é uma provocação, cuja intenção é melhorar a qualidade do ensino, atingindo todos os alunos que fracassam em suas salas de aula" (MANTOAN, 2004, p. 197). Diante da percepção dessa autora, compreende-se que a inclusão não está vinculada apenas a alunos com deficiência, mas a todo e qualquer estudante que, por algum motivo, esteja em atraso escolar ou com defasagem de aprendizagem.

A formação como base para uma Educação Inclusiva de qualidade é necessária para um perfeito desenvolvimento da educação. De acordo com a Lei de Diretrizes e Bases da Educação - LDB, Lei n9394/96, os professores devem ter uma formação inicial em cursos superiores de licenciatura.

Conforme pesquisa realizada por Pimentel (2012, p. 139), "os professores da escola básica se consideram despreparados para o trabalho com estudantes com deficiência". Esse sentimento de incapacidade pode ser reflexo de uma formação inicial deficitária, na qual não foram desenvolvidas as competências e as habilidades necessárias para uma educação inclusiva. 
A formação inicial não contempla todas as necessidades dos professores de classes inclusivas, sendo assim, eles devem procurar uma formação continuada em nível de Pós-graduação stricto senso e/ou lato senso, ou uma formação em serviço que envolva pesquisa a respeito da própria prática. Concordando com Pimentel (2012, p. 148), “embora haja ampliação de abordagem no currículo da Pedagogia, ainda assim reconhece-se que estes saberes não são suficientes para a construção de práticas inclusivas na escola”. Isso ocorre porque, diante da diversidade encontrada em sala de aula, apenas com uma formação contínua e que vise sempre a pesquisa esse professor estará preparando-se de forma adequada a atender as necessidades de seus estudantes.

Pimentel (2012) afirma que deve estar prescrito no Projeto Político Pedagógico PPP das escolas condições que assegurem momentos de formação em serviço, os quais contribuem para a valorização dos profissionais da educação. A autora ainda afirma que essa "forma de estudo em serviço (...) deve ter caráter de direito e dever do docente, deve ser remunerado, ininterrupto e abranger temáticas específicas e pertinentes às questões emergidas no contexto da prática pedagógica desenvolvida em sala de aula" (2012, p. 150). No Distrito Federal, existem alguns cursos ofertados pela EAPE para a formação do professor em serviço, mas apenas essa formação de 40h e 60h não são suficientes.

Quando a inclusão não ocorre de modo a promover o pleno desenvolvimento do aluno, Pimentel (2012, p. 140) chama esse ato de

pseudoinclusão, ou seja, apenas uma figuração do estudante com deficiência na escola regular, sem que o mesmo esteja devidamente incluído no processo de aprender. Estar matriculado e frequentando a classe regular não significa estar envolvido no processo de aprendizagem daquele grupo.

A autora ainda destaca que a pseudoinclusão é uma forma de expulsão mascarada e sua prática promove uma violência simbólica, a qual pode gerar sentimentos de incapacidade e não pertencimento.

\subsubsection{Formação-Bidocência}

A Bidocência está ganhando um espaço cada vez mais significativo nas discussões a respeito de Educação Inclusiva, pois é uma forma de permitir que o respeito e o acesso aos conhecimentos sejam alcançados por todos sem distinções. A presença de dois 
professores em sala de aula tem como objetivo uma parceria que visa à real inclusão do estudante com deficiência em uma sala de aula regular.

De acordo com Camargo e Sarzi (2012), é importante que os conhecimentos trocados entre os professores não se restrinjam ao aluno que tenha uma deficiência, mas que se estenda aos demais estudantes da turma. Vale ressaltar que o segundo professor também é responsável por toda a turma, juntamente com o professor regente. Eles devem trabalhar em parceria, buscando sempre estratégias e alternativas de ensino para que todos consigam alcançar os objetivos almejados.

O Segundo Professor ou Bidocente deve estar em turmas que possua educandos que necessitem desse suporte. Sendo assim, segundo Beyer (2005), umas das hipóteses que contempla essa necessidade é quando existem diversos ritmos de aprendizagem em uma turma e elas se distanciam muito umas das outras, assim, um único docente não é capaz de atender a todos os estudantes com eficiência.

Em seu artigo $2^{\circ}$, inciso I, A Lei Ordinária ${ }^{\circ}$ CM 0004/2015, do Município de Armazém, no Estado de Santa Catarina, define como funções do segundo professor que atua em séries iniciais:

co-reger a classe juntamente com o professor da turma; contribuir, em razão do seu conhecimento específico, com a proposição de procedimentos diferenciados para qualificar a prática pedagógica; acompanhar o processo de aprendizagem dos educandos de forma igualitária (ARMAZÉM, 2015, p. 2).

Essas funções deixam evidentes que o Bidocente é tão responsável pela turma quanto o professor da classe. O que o diferencia claramente do professor regente é a sua especialidade em planejar estratégias diferenciadas de aprendizagem que englobem toda a turma, com o objetivo de incluir todos nas atividades propostas.

Milttler (2003) entende que a presença de dois professores em sala de aula pode ser uma experiência nova para a maioria dos professores e esse aspecto pode ser negativo em alguns pontos, pois alguns docentes se sentem "desconcertados" com a presença do outro e tendem a imaginar uma perda de sua autonomia em sala. Uma solução para evitar isso seria a de troca constante entre os professores, assim, enquanto um atende ao aluno com deficiência individualmente o outro estaria com a classe, tendo sempre uma troca de papéis entre esses docentes. 
Alguns relatos foram encontrados acerca dessas experiências de se possuir dois professores em sala de aula, um atendendo a classe no todo e outro oferecendo atenção ao aluno com deficiência.

No texto de Fontana, Furgeri e Passos (2013), é relatado um caso de bidocência vivenciado por uma professora no Estado de São Paulo, onde a docente de educação especial foi solicitada para acompanhar uma aluna com baixa visão. O trabalho da docente era de escriba para a aluna.

As autoras Fontana, Furgeri e Passos (2013, p. 152) relatam que "com Flávia, Lorena vivia ritos de professora: preparava material ampliado, planejava atividades, tirava cópias e preparava textos. Ficava em sala de aula com a professora. Para Flávia, a presença diária de Lorena era indispensável”. O que fica visível ao longo da explicação é de que a professora Lorena não tinha auxílio da professora da classe, apenas ao final de algum tempo a professora relata que teve auxílio na preparação de materiais para a aluna.

Um dia, no meio do período de aulas, fui, preocupada, até a sala da Flávia porque não havia deixado, no dia anterior, tarefas para ela. Qual não foi minha surpresa e alegria quando vi a professora trazendo-me as atividades que havia feito para a aluna, perguntando-me se o tamanho das letras estava bom e elogiando a menina. (FONTANA, FURGERI E PASSOS, 2013, p. 152).

Essa discussão é importante, porque isso acontece em diversas salas de aula. Os alunos com deficiência recebem auxílio de outro professor ou monitor e, mesmo assim, não acompanham a classe, pois os professores não preparam materiais para o aluno referente ao conteúdo trabalhado com a turma e deixam o estudante como exclusividade do outro professor.

\subsubsection{Deficiências}

Conceituar uma deficiência é, de certo modo, um trabalho complexo, pois, ao fazer uma análise de suas características, não é possível simplesmente excluir o sujeito do seu contexto social, das suas especificações, definindo-o apenas em uma classificação limitada. De acordo com a Política Nacional de Educação Especial na Perspectiva da Educação Inclusiva (2007, p. 9), "as pessoas se modificam continuamente, transformando o contexto no qual se inserem”. Sendo assim, não existe um conceito estagnado e que não sofra alterações ao longo dos anos para um sujeito com alguma deficiência. 
Para uma simples conceituação a respeito das pessoas com deficiência, de acordo com a Política Nacional de Educação Especial (2007), é entendido que são aquelas que "têm impedimento de longo prazo, de natureza física, mental ou sensorial que, em interação com diversas barreiras, podem ter restringida sua participação plena e efetiva na escola e na sociedade" (MEC, 2007, p. 9). Vale destacar que, com as adaptações razoáveis, existe uma grande possibilidade de essas barreiras físicas serem eliminadas e as pessoas com deficiências serem beneficiadas e até mesmo diminuir a sua limitação naquele espaço.

A deficiência intelectual é, de acordo com as Orientações Pedagógicas para a Educação Especial (apud AAMR), uma “incapacidade caracterizada por importantes limitações, tanto no funcionamento intelectual como no comportamento adaptativo, expressa nas habilidades adaptativas conceituais, sociais e práticas. Essa incapacidade tem início antes dos 18 anos de idade" (GDF, 2010, p. 22). Sendo assim, é um estado de funcionamento cerebral particular, iniciado na infância, com diversas características e que pode responder a estímulos e apoios oferecidos individualmente à pessoa.

As deficiências sensoriais são divididas em três: deficiência auditiva ou surdez, deficiência visual e surdocegueira. A Deficiência auditiva/surdez, de acordo com o Decreto $\mathrm{n}^{\circ}$ 5.296/2004 é uma "perda bilateral, parcial ou total de quarenta e um decibéis (dB) ou mais, aferida por audiograma nas frequências de 500HZ, 1000HZ, 2000HZ e 3000HZ" (BRASIL, 2004, p. 23). Os estudantes que apresentem essas deficiências podem ser atendidos tanto em classes regulares, quanto em escolar especiais específicas para surdos. A definição de para qual escola o aluno será encaminhado deverá partir da família do estudante que pode optar por um ensino oralista (classe regular) ou na educação bilíngue em Libras nas escolas especializadas.

A Deficiência Visual pode ser dividida em dois seguimentos: a cegueira e a baixa visão. De acordo com o Decreto $n^{\circ} 5.296 / 2004$,

cegueira, na qual a acuidade visual é igual ou menor que 0,05 no melhor olho, com a melhor correção óptica; a baixa visão, que significa acuidade visual entre 0,3 e 0,05 no melhor olho, com a melhor correção óptica; os casos nos quais a somatória da medida do campo visual em ambos os olhos for igual ou menor que $60 \mathrm{o}$; ou a ocorrência simultânea de quaisquer das condições anteriores (BRASIL, 2004, p. 23).

De forma simplificada, a cegueira é a ausência total de visão, chegando até mesmo a perda total de projeção de luz. A baixa visão é um prejuízo da função visual mesmo após tratamento e/ou refração óptica (GDF, 2010). 
A surdocegueira não é apenas um somatório de deficiências (visual e auditiva). A pessoa com essa deficiência pode apresentar dificuldades nos sentidos que a permitam perceber os fatos que a cercam e na antecipação do que acontece ao seu redor. É necessário que se levem em consideração no diagnóstico da surdocegueira os graus de perda auditiva e visual, assim como se são apresentadas ou não dificuldades motoras e neurológicas no indivíduo.

As Deficiências Múltiplas - DMU são caracterizadas pelo "conjunto de duas ou mais deficiências associadas, podendo ser de ordem física, sensorial e/ou intelectual" (GDF, 2010, p. 27). Esse tipo de deficiência não pode ser caracterizado apenas como um somatório de doenças, mas, sim, pela observação quanto ao grau de implicação dessas deficiências no desenvolvimento da pessoa.

As Deficiências Físicas são, segundo o livro Saberes e Práticas de Inclusão do Ministério da Educação (2006, p. 11),

\footnotetext{
comprometimento do aparelho locomotor que compreende o sistema osteoarticular, o sistema muscular e o sistema nervoso. As doenças ou lesões que afetam quaisquer desses sistemas, isoladamente ou em conjunto, podem produzir quadros de limitações físicas de grau e gravidade variáveis, segundo(s) segmento(s) corpora(is) afetado(s) e o tipo de lesão ocorrida.
}

As deficiências físicas são caracterizadas pelo comprometimento na mobilidade, na coordenação motora de maneira geral e, até mesmo, na fala. Geralmente elas são advindas de lesões neurológicas, neuromusculares, ortopédicas, reumáticas ou má formações de natureza congênita (GDF, 2010).

\subsubsection{Transtorno Global do Desenvolvimento - TGD}

De acordo com a Política Nacional de Educação Especial na Perspectiva da Educação Inclusiva (2007, p. 9), os estudantes com transtornos globais do desenvolvimento TGD "são aqueles que apresentam alterações qualitativas das interações sociais recíprocas e na comunicação, um repertório de interesses e atividades restrito, estereotipado e repetitivo". Neste grupo, incluem-se os autistas, as síndromes do espectro autista e a psicose infantil.

O Transtorno Autista é caracterizado por um desenvolvimento anormal alterado antes dos três anos de idade e pode apresentar alterações nas interações sociais, na área de comunicação; e um comportamento focalizado e repetitivo. Existe grande dificuldade para 
realizar um diagnóstico correto desse transtorno, com isso, as observações para tal diagnóstico devem ser executadas visando a todos os aspectos que podem vir a acometer um autista. Tais comportamentos podem ser: dificuldade de contato visual direto, expressão facial, posturas corporais e gestos para regular a interação (GDF, 2010). Há também casos de comprometimento qualitativo na comunicação, em que pode-se ter ou não uma linguagem falada. São recorrentes situações de dificuldade de iniciar e/ou manter uma conversa com o sujeito.

O Autismo Atípico ocorre após os três anos de idade, quando a criança não apresentará todas as características do autismo. Sendo assim, é possível que haja interações sociais recíprocas, uma comunicação, comportamentos limitados, estereotipados ou repetitivos, o que caracteriza um quadro de autismo infantil. Este tipo de autismo acomete a criança que apresenta um grau de retardo mental profundo ou um transtorno específico grave de desenvolvimento de linguagem.

O Transtorno de Rett é caracterizado por um desenvolvimento inicial aparentemente normal, mas em que há perda da linguagem, da marcha e do uso das mãos entre os sete e 24 meses. Esse transtorno também está associado a um atraso no desenvolvimento craniano.

O Transtorno Desintegrativo da Infância é marcado por um período de desenvolvimento complemente normal da criança, quando ocorre uma perda das habilidades já adquiridas, em poucos meses. Também são características a perda pelo interesse no ambiente e começam a aparecer condutas estereotipadas e repetitivas. Este transtorno também pode ser chamado de "demência infantil, psicose desintegrativa, psicose simbólica ou síndrome de Heller" (GDF, 2010, p. 30).

O Transtorno de Asperger ou Síndrome de Asperger é caracterizado por uma limitação nas interações sociais. Geralmente as pessoas portadoras dessa Síndrome têm um repertório de atividades e interesses restritos. O que as difere de um autismo é que não existe retardo ou deficiência de linguagem ou no desenvolvimento cognitivo. Algumas vezes, podem ocorrer episódios psicóticos no início da idade adulta.

\subsubsection{Altas Habilidades}

Segundo a Política Nacional de Educação Especial na Perspectiva da Educação Inclusiva (2007, p. 9), os alunos com altas habilidades/superdotação 
demonstram potencial elevado em qualquer uma das seguintes áreas, isoladas ou combinadas: intelectual, acadêmica, liderança, psicomotricidade e artes, além de apresentar grande criatividade, envolvimento na aprendizagem e realização de tarefas em áreas de seu interesse.

A SEDF adota como referencial teórico para definir a superdotação/altas habilidades o Modelo dos Três Anéis de Renzuli (GDF, 2010). Os três fatores desse modelo são habilidades acima da média, envolvimento com a tarefa e criatividade.

Vale destacar que o importante não é o fato de os indivíduos ser ou não superdotados, mas de eles desenvolverem um comportamento de superdotação, no qual são capazes de ampliar esse conjunto de habilidades e aplicá-las em qualquer área de desenvolvimento humano (GDF, 2010).

\subsubsection{Diagnóstico}

De acordo com SEDF (2014), a avaliação diagnóstica pela equipe de atendimento educacional especial é imprescindível para o ingresso do estudante na Educação Especial. Esse processo contribui para a escolarização do discente, pois será possível respeitar as suas especificidades, porém “essa avaliação não tem sido suficiente para orientar a organização pedagógica de caráter qualitativo, no atendimento a esse público" (SEDF, 2014, p. 21). Sob essa ótica, apenas a avaliação diagnóstica não tem sido satisfatória para nortear a organização pedagógica para esses estudantes, conforme o documento, “a avaliação diagnóstica em si não é capaz de sustentar um ideário de inclusão e coesão social, onde todas as pessoas aprendam" (Idem). Esse dado demonstra que a escola pública, apesar de declarar em seus documentos que possui uma educação inclusiva em todas as instituições, ainda não conseguiu de fato conceber a inclusão de modo a proporcionar uma educação de qualidade para todos os seus estudantes, por não conseguir atender com eficiência todas as suas necessidades, principalmente no que diz respeito a uma avaliação diagnóstica eficaz.

\subsection{Adaptação Curricular}

As adaptações curriculares estão previstas nos Parâmetros Curriculares Nacionais - PCNs, com o objetivo de tornar o currículo apropriado aos estudantes com deficiência, transtorno global do desenvolvimento e altas habilidades. Essas adaptações têm por objetivo apresentar uma resposta às demandas da sociedade que são prejudicadas pela homogeneização do currículo e das ações pedagógicas. Desse modo, ao serem realizadas as modificações, é 
necessário que se considere o cotidiano das escolas e as necessidades e capacidades de cada estudante, buscando sempre a sua escolarização.

De acordo com SEDF (2014, p. 20), “tomando como base o Currículo, as adequações curriculares devem ser organizadas em um documento no qual esteja previsto o conteúdo a ser desenvolvido, bem como o processo de avaliação para a aprendizagem do discente". O processo de adequação curricular deve ser realizado com a participação do professor regente, da equipe pedagógica, da equipe de atendimento educacional especializado e da direção da escola; todos devem estar cientes das alterações realizadas para a aprendizagem do estudante. Vale destacar que a adaptação curricular só deve ser realizada após uma "avaliação diagnóstica" (SEDF, 2014) e processual para a realização de um efetivo planejamento coletivo.

De acordo com MEC (2006, p. 61), existem algumas características nas adaptações curriculares que facilitam o atendimento da pessoa com deficiência; são elas:

Flexibilidade, isto é, a não obrigatoriedade de que todos os alunos atinjam o mesmo grau de abstração ou de conhecimento, num tempo determinado; Acomodação, ou seja, a consideração de que, ao planejar atividades para uma turma, deve-se levar em conta a presença de alunos com necessidades educacionais especiais e contemplá-los na programação; Trabalho simultâneo, cooperativo e participativo, entendido como a participação dos alunos com necessidades educacionais especiais nas atividades desenvolvidas pelos demais colegas, embora não o façam com a mesma intensidade, em necessariamente de igual modo ou ação e grau de abstração.

Essas características favorecem uma efetiva inclusão da pessoa com deficiência, pois ela poderá participar como qualquer outro estudante das atividades diárias da turma, mas com exercícios e atividades próprias às suas capacidades de desenvolvimento e habilidade. Ressalta-se que as atividades devem ser preparadas para toda a turma, levando em consideração a presença do aluno com deficiência em sala. As modificações podem ser realizadas nas atividades físicas e nos materiais preparados para a sala de aula, além de um maior preparo por parte do professor em trabalhar com esses estudantes as adequações curriculares propostas a ele.

Concordando com as orientações do MEC (2006), é importante que as respostas à adequação curricular estejam previstas e respaldadas no PPP das escolas. Não se deve construir um novo currículo, mas, sim, adequá-lo progressivamente.

De acordo com as Orientações Pedagógicas: Educação Especial (2010), é indispensável que, para a efetiva execução das adaptações curriculares, é necessária uma 
postura de disponibilidade dos agentes educacionais em atuarem de maneira "diversificada e eficaz frente às dificuldades de aprendizagem dos estudantes" (GDF, 2010, p. 40). Serão necessárias pequenas adaptações diárias e às vezes grandes e profundas reorganizações do currículo, utilizando-se até mesmo recursos especiais, para que a adaptação se efetive de fato.

Ainda segundo as Orientações Pedagógicas: Educação Especial (2010), existem algumas modificações que serão consideradas como "muito significativas", pois transformarão expressivamente o planejamento geral aplicado à turma, o que pode requerer, com certa frequência, serviços especializados e individualizados. Tais serviços podem ser um atendimento especializado na sala de recursos, com a equipe de apoio especializado; um acompanhamento pelo Monitor em sala de aula ou um professor Bidocente; serviços de apoio em parceria com as áreas de saúde, assistência social, trabalho e lazer.

O documento Saberes e Práticas da Inclusão do MEC (2006) prevê que podem ser consideradas algumas intensidades de apoio a ser oferecido aos estudantes com deficiência; são elas:

Iminentes: episódicos, nem sempre necessário, transitório e de pouca duração (exemplo: apoio em momentos de crise, em situações específicas de aprendizagem). Limitado: por tempo determinado e com fim definido (exemplo: reforço pedagógico para algum conteúdo durante um semestre, desenvolvimento de um programa de psicomotricidade etc.). Extensivo: regular, em ambientes definidos, sem tempo limitado (exemplo: atendimento na sala de recursos ou de apoio psicopedagógico, atendimento itinerante). Pervasivo: constante, com alta intensidade e longa duração (ou ao longo de toda a vida), envolvendo equipes e muitos ambientes de atendimento. (MEC, 2006, p. 79).

Essa intensidade de atendimento visa proporcionar ao estudante um melhor atendimento em cada uma das áreas em que ele necessita de apoio específico. Assim, as adequações curriculares devem ser feitas levando sempre em consideração as reais necessidades dos estudantes com deficiência. 


\section{CAPÍTULO II - TRAMAS METODOLÓGICAS: O CAMINHO PERCORRIDO}

O presente capítulo tem como objetivo apresentar as perspectivas teóricometodológicas que orientaram esta investigação. A metodologia adotada em uma observação define os rumos que ela assume na interpretação dos dados e nas escolhas dos instrumentos de coleta de dados. De acordo com Gil (1995, p. 42), o objetivo principal de uma pesquisa é “descobrir respostas para problemas mediante o emprego de procedimentos científicos". Diante dessa perspectiva, este trabalho guiar-se-á pela abordagem da pesquisa qualitativa.

Apresento como base metodológica a análise qualitativa e a busca em compreender os aspectos da Educação Inclusiva necessários à prática docente do Pedagogo formado no curso de Pedagogia da Universidade de Brasília. Nesta exploração, foram utilizadas a legislação relativa à Educação Especial e Inclusiva, assim como, o Projeto Acadêmico do Curso de Pedagogia da UnB, com enfoque nas disciplinas obrigatórias existentes no curso sobre Educação Especial; o PPP das escolas observadas; e análise qualitativa dos dados obtidos por meio da observação de campo, da entrevista semiestruturada e do grupo focal com as crianças.

\section{FUNDAMENTOS DA PESQUISA QUALITATIVA}

A pesquisa qualitativa em Ciências Sociais na Educação, no Brasil, é recente, "mas vem crescendo e apresentando contribuições significativas" (WELLER e PFAFF, 2013, p. 13). Para Strauss e Corbin (2008, p. 23), “o termo 'pesquisa qualitativa' [quer] dizer qualquer tipo de pesquisa que produza resultados não alcançados através de procedimentos estatísticos ou de outros meios de quantificação”. Desta forma, a ela pode ser utilizada para compreender a sociedade, estilos de vida, comportamentos e até mesmo a educação.

Realizando uma breve retrospectiva histórica da pesquisa qualitativa nos processos educacionais, Weller e Pfaff (2013) esclarecem que ela teve início no início do século XIX nas escolas europeias e, apenas na segunda metade do século XX, ela apresentou uma maioria significativa em outros países. Segundo Gatti e André (2013, p. 29), "as origens dos métodos qualitativos de pesquisa remontam aos séculos XVIII e XIX, quando vários sociólogos, historiadores e cientistas sociais, insatisfeitos com o método de pesquisa das ciências sociais, físicas e naturais (...) buscaram novas formas de investigação". As primeiras pesquisas que utilizaram a abordagem qualitativa mostram que os pesquisadores sentiam necessidade de utilizar um método de observação. Anteriormente o único tipo aceito 
cientificamente era a pesquisa quantitativa, mas, a partir dessa necessidade, foram abertas lacunas para que a pesquisa qualitativa entrasse como cientificamente aceita.

De acordo com Gatti e André (2013, p. 33), por meio do crescimento da educação e da busca por respostas a questionamentos observados no ambiente educacional, a pesquisa qualitativa veio na busca por métodos alternativos, ao invés de modelos experimentais anteriormente utilizados. Conforme esses autores,

todo esse conjunto de possibilidades para estudos de problemas em Educação ampliou o universo epistemológico da discussão dos fatos educacionais e permitiu, pelas novas posturas assumidas, um engajamento mais forte dos pesquisadores e pesquisados, criando um compromisso maior com as necessidades e possibilidades de melhorias socioeducacionais por meio de intervenções diretas nas realidades pesquisadas ou pelo envolvimento nos debates na formulação das políticas educativas" (GATTI; ANDRÉ, 2013, p. 34).

De acordo com Weller e Pfaff (2013, p. 15), "nas Ciências da Educação, o impacto e a difusão de métodos qualitativos em uma escala maior ocorreu somente entre as décadas de 1950 e 1970 na Inglaterra, França e nos Estados Unidos (...)”. Ainda segundo as autoras, diferentes métodos foram desenvolvidos em análise de dados e outros foram remodelados ou adotadas novas bases teóricas mais amplas e profundas.

Segundo Strauss e Corbin (2008, p. 24), quando se pensa em análise qualitativa, não se refere a uma quantificação, mas, sim, a um "processo não matemático de interpretação, feito com o objetivo de descobrir conceitos e relações nos dados brutos e de organizar esses conceitos e relações em um esquema explanatório teórico".Ainda de acordo com os autores, "métodos qualitativos podem ser utilizados para obter detalhes intrincados sobre fenômenos como sentimentos, processos de pensamento e emoções que são difíceis de extrair ou de descobrir por meio de métodos de pesquisa mais convencionais" (Idem). Esses são aspectos bem relevantes em uma pesquisa quantitativa, pois os dados brutos não apresentam ao pesquisador a possibilidade de compreender o contexto social em que aqueles dados foram produzidos nem de conseguir que se saiba qual o sentimento do pesquisado ao quantificar o que ele sabe. Com a pesquisa qualitativa, é possível compreender os fatores externos e internos da produção dos dados.

Strauss e Corbin (2008, p. 25) entendem que a "análise é uma interação entre os pesquisadores e os dados", dessa forma, a análise qualitativa deve relacionar estritamente o sujeito ou a situação ao pesquisador que realizará a análise. 
De acordo com Krüger, Gatti e André apud Weller e Pfaff (2013, p. 15), “as principais abordagens qualitativas utilizadas atualmente nas pesquisas educacionais podem ser classificadas em três tipos: etnografia, história oral e análise biográfica; análises interacionistas; e análise de discurso". O método mais antigo utilizado na área de Educação é a Etnografia.

Para garantir rigor e qualidade nas pesquisas, "as abordagens qualitativas trazem um grau de exigência grande para o trato com a realidade e sua reconstrução justamente por postularem o envolvimento do pesquisador" (BRITO apud GATTI; ANDRÉ 2013, p. 36). Diante do exposto, os pesquisadores devem ficar atentos aos instrumentos que utilizarão para a coleta de dados e o modo de interpretar as informações obtidas, visando sempre à maior clareza e fidedignidade da pesquisa.

\subsection{As Instituições}

As instituições analisadas nesta pesquisa situam-se nas Regiões Administrativas RA de Ceilândia e Asa Norte. A escola de Ceilândia atende a alunos da Educação Infantil até o $5^{\circ}$ ano do Ensino Fundamental, e a escola da Asa Norte acolhe estudantes do $1^{\circ}$ ano $5^{\circ}$ ano do Ensino Fundamental.

As escolas foram selecionadas por possuírem, em seu quadro de servidores, professores que atendiam aos requisitos da pesquisa de estarem trabalhando no $5^{\circ}$ ano e atuando em uma turma inclusiva. A seleção também é por elas Apresentarem características econômicas, populacionais, sociais e estruturais diferentes.

A Região Administrativa de Ceilândia é também conhecida como RA IX. Sua construção ocorreu a partir de uma Comissão para Erradicação de Favelas em 1971, quando os moradores dessa cidade ganharam lotes para a construção de suas residências. Hoje Ceilândia possui um campus da Universidade de Brasília - UnB que oferece os cursos de Terapia Ocupacional, Farmácia, Enfermagem, Fisioterapia, Fonoaudiologia e Saúde Coletiva. Também possui um campus do Instituto Federal de Brasília - IFB e outras instituições de cursos superiores. Nos últimos anos, a cidade tem alcançado grande progresso, mas ainda possui algumas favelas como a do Sol Nascente e a do Pôr do Sol, esta última está sendo considerada uma das maiores favelas da América Latina. É uma cidade que atende, em seus serviços básicos de saúde e educação, a muitas pessoas vindas do Entorno de Brasília, principalmente de Águas Lindas, cidade do Estado de Goiás mais próxima dessa localidade. 
A escola pesquisada na regional de Ceilândia localiza-se em um ponto estratégico da cidade. Apesar de estar situada em Ceilândia Sul, o colégio fica bem próximo ao Centro de Ceilândia, ao Hospital Regional e ao Fórum da cidade. É uma escola de Ensino Fundamental, anos iniciais, que também atende turmas de Educação Infantil. A escola tem uma classe especial de estudantes surdos, cuja aprendizagem ocorre por meio da Língua Brasileira de Sinais - Libras; também há turmas inclusivas; e recebe estudantes de toda a RA IX.

A Região Administrativa de Brasília nasceu do sonho de Dom Bosco, sendo concretizada por Juscelino Kubitschek em 1960. De acordo com GDF (2014), Brasília é formada por: Asa Sul e Asa Norte; Setor Militar Urbano; Setor de Garagens e Oficinas; Setor de Indústrias Gráficas; Área de Camping, Eixo Monumental, Esplanada dos Ministérios, Setor de Embaixadas Sul e Norte, Vila Planalto, Granja do Torto, Vila Telebrasília, Setor de áreas Isoladas Norte. Também conhecida como RA I foi criada para ser a sede do governo brasileiro. Hoje é conhecida por seu elevado padrão de vida e uma das maiores escolaridades do Brasil.

A escola selecionada para a realização da pesquisa em Brasília fica localizada na Asa Norte e atende a alunos do Ensino Fundamental, séries inicias, especificamente do $1^{\circ}$ ao $5^{\circ}$ ano. Ela situa-se próxima à Universidade de Brasília e é conhecida como uma escolamodelo no atendimento de alunos com autismo e Transtorno Global do Desenvolvimento. Nela há classes especiais de TGD e classes inclusivas. Os estudantes, durante um dia na semana, têm aulas na escola parque, onde desenvolvem atividades em artes e educação física. Apesar de estar localizada na Região Administrativa de Brasília, ela atende a estudantes de diversas regiões administrativas com vulnerabilidade social.

\subsection{Os Interlocutores}

As observações para esta pesquisa foram realizadas em duas turmas do $5^{\circ}$ ano do Ensino Fundamental de duas Escolas Públicas do DF que atendem a crianças em classes inclusivas. A escolha por uma turma de $5^{\circ}$ ano consiste no fato de as crianças estarem no último ano do Ensino Fundamental, séries iniciais, por dominarem a leitura e a escrita e por já possuírem um pouco mais de maturidade que os estudantes dos anos anteriores e podem, assim, compreender melhor os fatos que ocorrem ao seu redor no interior da escola e da sala de aula. 
O perfil identitário dos docentes escolhidos para a realização da pesquisa foram professores efetivos da rede pública de ensino do Distrito Federal, não podendo ser profissionais de contrato temporário; oriundos da Universidade de Brasília; terem cursado graduação em Pedagogia; e que já estão trabalhando em sala de aula na rede pública de ensino há, no mínimo, dois anos ou dois anos após a conclusão do seu curso na UnB.

\section{Os Professores}

Tabela 1 - Os Professores selecionados

\begin{tabular}{|c|c|c|}
\hline & Ceilândia & Asa Norte \\
\hline Nome Fictício & Carlos & Antônio \\
\hline Idade & 40 anos & 34 anos \\
\hline Sexo & Masculino & Masculino \\
\hline Graduação & UnB/Pedagogia & UnB/Pedagogia \\
\hline Ano de Conclusão & 2003 & 2010 \\
\hline Especialização & Sim: Psicopedagogia & Não \\
\hline $\begin{array}{l}\text { Ano de ingresso na } \\
\text { SEDF }\end{array}$ & 1997 & 2005 \\
\hline Ano em que atua & $5^{\circ}$ ano & $5^{\circ}$ ano \\
\hline $\begin{array}{l}\text { Deficiências dos alunos } \\
\text { em sala }\end{array}$ & $\begin{array}{l}\text { TGD (Asperger) e altas } \\
\text { habilidade }\end{array}$ & TGD (Clássico) \\
\hline $\begin{array}{l}\text { Disciplinas cursadas na } \\
\text { UnB sobre a Educação } \\
\text { Especial }\end{array}$ & $\begin{array}{l}\text { Fundamentos da Educação } \\
\text { Especial }\end{array}$ & $\begin{array}{l}\text { O Educando com } \\
\text { Necessidades Educacionais } \\
\text { Especiais; PNEE- } \\
\text { Aprendizagem e } \\
\text { Desenvolvimento do } \\
\text { PNEE. }\end{array}$ \\
\hline
\end{tabular}

Ambos os professores ingressaram na Secretaria de Educação do DF apenas tendo o Magistério e, no decorrer do exercício da docência e com a mudança da legislação, buscaram a Universidade de Brasília para ingressarem no curso de graduação em Pedagogia. Os dois docentes observados são do sexo masculino e exercem a docência há mais de dez anos.

Os educadores estavam em uma classe de integração inversa, onde cada turma tinha 14 alunos sem deficiência e um com deficiência, transtorno global do desenvolvimento e altas habilidades. Cada uma das turmas totaliza, assim, 15 estudantes. 


\section{Os Estudantes}

As crianças que participaram desta pesquisa eram alunos das classes de $5^{\circ}$ ano onde os professores selecionados de Ceilândia e da Asa Norte lecionavam. Um grupo bastante heterogêneo com meninos e meninas na faixa etária de 9 a 13 anos. Cada uma das turmas possuía 15 estudantes.

A escola da Região Administrativa de Ceilândia tinha em uma classe um aluno com Síndrome de Asperger, uma estudante com altas habilidades e um aluno sem diagnóstico que apresentava características do espectro autista. Na Asa Norte, a turma tinha um aluno com Autismo Clássico.

\subsection{Os procedimentos de pesquisa/instrumentos}

\subsubsection{Análise Documental}

O uso de documentos na pesquisa qualitativa é utilizado para "contextualizar o fenômeno, explicar suas vinculações mais profundas e completar as informações coletadas através de outras fontes" (ANDRÉ, 2008, p. 28). A literatura "pode fornecer questões, conceitos iniciais e ideias para a amostragem teórica" (STRAUSS; CORBIN, 2008, p. 62). Isso traz, em um primeiro plano, conceituações teóricas de determinados termos.

Strauss e Corbin (2008, p. 58) levantam o questionamento de que os "materiais podem ser usados para aumentar, e não para restringir, o desenvolvimento da teoria”. Nesse caso, os materiais a que os autores se referem é a literatura na área a ser pesquisada. Diante dessa colocação, é imprescindível que o pesquisador tenha claro os documentos que são necessários para a análise e o entendimento efetivo do seu problema de pesquisa, pois, de certo modo, muitos deles podem tirar o foco do problema da pesquisa, trazendo apenas uma revisão da literatura como tema principal.

Os documentos analisados nesta pesquisa são de caráter escrito, a qual consistiu em uma extensa busca acerca da legislação internacional, nacional e distrital a respeito das pessoas com deficiência; da análise do Projeto Acadêmico do Curso de Pedagogia da Universidade de Brasília; dos planos de curso das disciplinas "O Educando com Necessidades Especiais", "Aprendizagem e Desenvolvimento do PNEE" e "Libras"; e do Projeto Político Pedagógico das escolas observadas. 


\subsubsection{Questionário}

O questionário é um instrumento de pesquisa utilizado principalmente como uma triagem prévia de dados dos participantes, sobretudo para identificar os que se encaixam no perfil da pesquisa a ser executada. Gil (1995, p. 124) define questionário como:

Técnica de investigação composta por um número mais ou menos elevado de questões apresentadas por escrito às pessoas, tendo por objetivo o conhecimento de opiniões, crenças, sentimentos, interesses, expectativas, situações vivenciadas etc.

O autor complementa que a principal diferença entre o questionário e a entrevista é que nesta as questões são realizadas oralmente. O questionário facilita a organização e a separação de dados. Atualmente, muitos dos questionários aplicados são realizados virtualmente. Por meio de algumas plataformas (Google docs, Encuestaetc.), é possível que a pessoa responda ao questionário e, imediatamente, sejam criados e enviados para o pesquisador tabelas e gráficos referentes aos dados obtidos na pesquisa.

Neste trabalho, o questionário (Apêndice I) foi utilizado com o objetivo de traçar um perfil inicial dos professores das escolas a serem analisadas. Por meio dos dados obtidos, foi possível identificar quais professores possuíam um perfil correspondente à necessidade da pesquisa de ser um professor formado em Pedagogia pela Universidade de Brasília e estar atuando em uma turma de $5^{\circ}$ ano inclusiva.

Os dois professores pesquisados solicitaram que o envio do questionário fosse realizado por e-mail, pois se sentiam mais à vontade para responder as questões em suas residências e para que não houvesse dificuldade na leitura das respostas.

\subsubsection{Observação Participante}

Segundo Gil (1995, p. 104), “a observação nada mais é do que o uso dos sentidos com vistas a adquirir os conhecimentos necessários para o cotidiano". Para autor, a principal vantagem da observação é a de que os fatos podem ser percebidos diretamente, sem qualquer interferência ou subjetividade que intervenham no processo de investigação social.

Existem três tipos de observação para Gil (1995): a observação simples, a observação participante e a observação sistemática. Nesta pesquisa, foi utilizada a observação participante, também conhecida como observação ativa. Nesse tipo, o pesquisador tem uma "participação real (...) na vida da comunidade, do grupo ou de uma situação determinada" (GIL 1995, p. 107-8). 
Pfaff (2013) alerta para a necessidade do pesquisador em estabelecer limites na sua participação no campo. A autora esclarece que o investigador deve realizar esta separação de acordo com o seu problema de pesquisa, o tempo em que fará a observação e o contexto social.

De acordo com André (2008, p. 28), “a observação é chamada de participante porque parte do princípio de que o pesquisador tem sempre um grau de interação com a situação estudada, afetando-a e sendo por ela afetado”. Essa citação retrata a necessidade de que, na investigação do tipo etnográfica, se busque a pesquisa participante para que o pesquisador possa interagir de maneira efetiva naquela realidade que ele propôs estudar.

Segundo Gil (1995), a observação participante pode assumir duas formas distintas: a natural e a artificial. A natural ocorre quando o observador pertence ao grupo ou espaço que será observado; já a artificial acontece quando é necessário que o observador se integre a um grupo para a realização de sua investigação.

A utilização de um roteiro de observação pré-estabelecido é essencial para nortear a coleta de dados. Cavalleiro (2013) sugere que as observações com características etnográficas no cotidiano escolar devem observar aspectos fundamentais: as expressões verbais e não verbais de professores e alunos; e a prática pedagógica do professor. A autora defende que, considerando esses três elementos, a observação será mais rica em detalhes e elementos de análise.

A pesquisa com traços etnográficos em sala de aula utiliza-se da observação concomitante com o uso de anotações e diários de campo, pois eles "oferecem subsídios para a análise em profundidade dos dados coletados" (PFAFF, 2013, p. 258). Cavalleiro (2013, p. 275) relata que

O registro contínuo será fundamental para se ter uma noção geral do que acontece no ambiente escolar: situações, diálogos, ambientes etc., tanto no que diz respeito ao espaço físico quanto à dinâmica da instituição e também as situações de interação entre os sujeitos.

Gil (1995) levanta uma crítica, a observação de que a pesquisa com traços etnográficos pode representar um incômodo para o pesquisado, pois a presença do observador pode provocar alterações no comportamento do observado. Esse aspecto deve ser levado em consideração, porque, com a presença do observador, a tendência dos observados é realizar tudo da forma mais perfeita e coerente possível. Isso faz que a observação perca, de certo modo, o caráter de neutralidade e de não possuir interferências externas. 
A observação participante utilizou um tópico guia de assuntos a serem analisados em sala de aula. São quesitos referentes à prática do professor em sala de aula e de que forma os alunos assimilam essa prática em seu dia a dia. Foi de fundamental importância que a inserção no contexto de sala de aula ocorresse de forma que os alunos ficassem à vontade, assim como o professor e a direção da escola. Foram utilizados diários de campo, com o objetivo de facilitar a análise de dados ao final desta pesquisa e para que nenhum dado fosse perdido ao longo das investigações.

\subsubsection{Projeto Político Pedagógico}

O Projeto Político Pedagógico das escolas é o instrumento, construído coletivamente, cujo intuito é apresentar objetivos e metas que devem ser alcançados durante a sua vigência. Para Veiga (2008, p. 13), o PPP deve ser "entendido como a própria organização do trabalho pedagógico da escola”. Dessa forma, demonstra intencionalidade do que se pretende realizar. O PPP deve ser construído coletivamente por professores, servidores, comunidade e alunos da instituição.

De acordo com Ferreira e Ferreira (2013), o PPP deve ser um instrumento que favoreça a inclusão do aluno com deficiência na escola e em sala de aula. Os autores percebem que isso não acontece e ele se torna apenas uma peça burocrática imposta pela lei.

Em 2014, a Secretaria de Educação do Distrito Federal entregou a todas as escolas públicas do DF um documento intitulado "Orientação Pedagógica - Projeto Político Pedagógico e Coordenação Pedagógica nas escolas”. Esse documento apresenta uma possível fórmula de construção do PPP pelas escolas. Nele é enfatizada a necessidade de ele ser construído democraticamente e após muita discussão por todo o corpo docente, pelos profissionais da educação e pela comunidade escolar.

Para a presente pesquisa, foram analisados os PPPs das escolas de Ceilândia e da Asa Norte. Os PPPs foram solicitados à direção de cada uma das instituições observadas e enviados ao e-mail da pesquisadora. Ambos os projetos referem-se ao ano de 2014 porque o PPP de 2015 ainda não estava completo. Ao comparar os dois PPPs ficaram evidentes significativas diferenças na estrutura e na elaboração de cada um. Como base para a análise dos Projetos, foi tomado como guia orientador, o documento "Orientação Pedagógica" (2014) da Secretaria de Educação do Distrito Federal. 


\subsubsection{Entrevista com Professores}

A entrevista na pesquisa qualitativa é utilizada para produzir "dados textuais que representam diretamente a perspectiva dos sujeitos da pesquisa" e a "necessidade de informações sobre as pessoas, contextos sociais, rituais ou cenas, que não são utilizados como único material para análise em profundidade" (PFAFF, 2013, p. 259). De acordo com André (2008, p. 28), “as entrevistas têm a finalidade de aprofundar as questões e esclarecer os problemas observados". Desse modo, a entrevista é utilizada pelo pesquisador para compreender os fenômenos que acontecem no contexto pesquisado e observado, buscando detalhes que não foram percebidos ou ficaram ofuscados na observação e são de relevância para a compreensão daquele determinado contexto social.

Pfaff (2013) não deixa determinado em seu texto quem deve ser o sujeito entrevistado, mas sugere que deve ser alguém que esteja relacionada ao seu problema de pesquisa e ao campo que está sendo investigado. A autora ainda aponta que o pesquisador deve entender que o seu entrevistado é um "especialista em seu campo social, enquanto o pesquisador deve comportar-se como um recém-chegado ou aluno e retrair-se com suas interpretações e entendimentos" (PFAFF 2013, p. 259). Essa declaração da autora refere-se à necessidade de o pesquisador entender que o entrevistado, naquele momento, é um especialista e que deve respeitar os seus conhecimentos não fazendo interpretações que não sejam expressas pelo sujeito pesquisado.

Outro ponto de destaque é a postura do pesquisador na entrevista. Alguns autores afirmam que ele não deve chegar ao entrevistado sem nenhum conhecimento prévio do assunto, e sim ter um domínio do conteúdo para poder realizar perguntas pertinentes ao entrevistado.

Segundo Pfaff (2013, p. 259), “existem diferentes formas relacionadas ao grau de estruturação da situação da entrevista pelo pesquisador". O tipo de entrevista utilizada nesta pesquisa é a semiestruturada, algumas perguntas centrais nortearam a discussão, mas podendo surgir questionamentos no decorrer na conversa.

A entrevista foi realizada ao final das observações participantes, com o objetivo de compreender se o professor que está atuando em sala de aula percebe as suas práticas pedagógicas para a inclusão, se ele compreende que elas fazem parte da sua rotina diária ou se ele ainda não consegue perceber essa interação. A entrevista consistiu apenas como uma constatação do que já foi observado na pesquisa participante. Foi realizada entrevista com os 
professores das duas escolas analisadas, Ceilândia e Asa Norte, utilizando-se um gravador para posteriormente reprodução do áudio.

\subsubsection{Grupo Focal com Crianças}

O grupo focal é um instrumento da pesquisa qualitativa. De acordo com Weller (2013), esse tipo de entrevista começou a ser utilizado após a Segunda Guerra Mundial como pesquisa de marketing e propaganda. Segundo Gatti (2012), apenas na década de 1980 essa técnica foi redescoberta e seu uso cresceu na investigação científica. Gatti (idem, p. 29) discorda de que o grupo focal é um tipo de entrevista, pois ela o considera "como proposta de troca efetiva entre os participantes". Sendo assim, esse conceito de que o grupo focal é uma troca foi empregada nesta pesquisa.

De acordo com Gatti (2012, p. 22), o "grupo focal não pode ser grande, mas também não pode ser excessivamente pequeno, ficando sua dimensão preferencialmente entre seis e 12 pessoas". Existe uma pequena divergência entre Gatti (2012) e Weller (2013, p. 54$55)$, porque Weller afirma que os grupos focais devem ter entre "seis a oito pessoas". Essa diferença relativa ao número de pessoas não altera a qualidade do grupo a ser pesquisado. Nesta pesquisa, foi adota a quantidade sugerida por Gatti.

A composição de um grupo focal não deve ser realizada de forma aleatória, porque algumas características que homogeneízam o grupo devem ser levadas em consideração na hora da escolha dos participantes. Gatti (2012) afirma que essa escolha deve considerar o tema e os objetivos a serem alcançados com a pesquisa. De acordo com a autora, as características comuns podem ser relativas à idade, ao gênero, às condições sociais, ao lugar de residência e à escolaridade, entre outros fatores. Outro ponto que deve ser observado na escolha do grupo é se as pessoas não se conhecem há muito tempo ou conhecem o moderador.

É recomendado que o convite para participação no grupo focal seja realizado de modo a conscientizar acerca da importância do estudo. Gatti (2012, p. 23) também "recomenda [não] dar aos participantes informações detalhadas sobre o objeto de pesquisa", apenas deve-se indicar detalhes vagos, para que o pesquisador não vá para o grupo com ideias preparadas e pré-formadas.

O grupo focal foi realizado com crianças menores de 18 anos e, nesse caso, foi necessário que existisse a autorização dos pais. O termo de livre consentimento esclarecido (Apêndice II) foi de fundamental para que as crianças pudessem participar da pesquisa. 
O grupo focal tinha o intuito obter, por meio do depoimento das crianças, dados acerca do seu entendimento de inclusão e práticas inclusivas. O grupo focal na escola de Ceilândia foi realizado com 13 crianças, uma a mais do que o recomendado por Gatti (2012), que recomenda grupos de até 12 pessoas. A incorporação dessa criança ocorreu porque o grupo seria realizado na mesma turma onde a observação foi concretizada. A turma observada tinha 15 estudantes, dos quais apenas uma criança não devolveu a autorização assinada e, no dia do grupo focal, uma faltou, ficando treze discentes.

Os fatores que homogeneizavam o grupo eram o fato de os estudantes estarem todos no $5^{\circ}$ ano do ensino fundamental; serem da mesma escola e sala de aula; e terem entre nove e 10 anos de idade.

O termo de consentimento livre esclarecido para menores de 16 anos foi entregue para os estudantes dois dias antes da realização do grupo focal. Tanto no dia quanto nos dias subsequentes, os alunos perguntaram a respeito do que se tratava a pesquisa. Assim como Gatti (2012) instrui, o tema foi exposto de forma breve, sem que ocorressem maiores explicações acerca do assunto, sendo apenas dito que seria uma pesquisa referente à inclusão.

O grupo focal foi realizado na mesma sala em que as crianças estudavam. No dia, as cadeiras foram dispostas em círculo, para que todos pudessem se ver, favorecendo assim a comunicação. Conforme Gatti (2012), a melhor forma de registro é por meio de um gravador de voz, devendo ser utilizados dois e é necessário que se tenha um terceiro de reserva, caso exista algum problema técnico com os outros. Desse modo, foi colocado um gravador ao centro do círculo e outros dois nas duas extremidades.

No início do grupo focal, foram realizadas uma breve autoapresentação da pesquisadora; uma explicação do tema da pesquisa; e como seria a forma de registro do trabalho. Novamente foi garantido ao grupo o sigilo dos registros e de seus nomes. Foi informado ao grupo de crianças que seria de fundamental importância o seu depoimento, assim como as suas opiniões e que não existia o certo ou o errado naquele momento.

O tema a respeito da inclusão foi introduzido para as crianças por meio da leitura de um gibi da Turma da Mônica relativo à Inclusão Social. O gibi está no anexo V deste trabalho. Em seguida, foi aberto para as crianças um momento de partilha.

O grupo focal também contou com a participação do professor da sala, o qual, em alguns momentos, fez intervenções e perguntas aos estudantes, tomando, assim, para ele, em parte, o papel de moderador da discussão também.

As perguntas que foram realizadas para as crianças foram: O que mais chamou a atenção de vocês na história que lemos juntos? O que vocês entendem por inclusão? Vocês 
percebem que aqui na escola existe a inclusão? Em algum momento, vocês já viram ou presenciaram momento de exclusão? Conte-me um pouco sobre isso. Vocês percebem que o professor de vocês tem atitudes inclusivas? Nas séries anteriores, os professores tinham atitudes de inclusão?

O grupo focal da Asa Norte foi realizado com dez estudantes. Todos eles entregaram o termo de livre consentimento esclarecido e os pais concordavam com a participação das crianças na pesquisa.

Assim como no grupo de Ceilândia, foi apresentado aos alunos o gibi da Turma da Mônica acerca de inclusão social e realizados os mesmos questionamentos do grupo anterior. Diferente do grupo de Ceilândia, as crianças da Asa Norte não conseguiram expor com clareza o proposto nas questões apresentadas a elas.

No dia do grupo focal, os estudantes da Asa Norte estavam muito agitados e não respeitavam o momento de fala de cada um dos colegas. Essa agitação é reflexo dos dias anteriores de observação, quando as crianças já estavam com esse comportamento e o professor não conseguia ter domínio da turma. $\mathrm{O}$ termo de consentimento livre esclarecido foi enviado para o aluno com autismo, mas os pais não autorizaram a sua participação. 


\section{CAPÍTULO III - ANÁLISE DO PROJETO ACADÊMICO DO CURSO DE PEDAGOGIA DA UNB}

\section{CURSO DE PEDAGOGIA DA UNIVERSIDADE DE BRASÍLIA - UNB}

A Faculdade de Educação - FE teve seu primeiro projeto no ano de 1962, mas ele não pode ser implementado por virtude do golpe militar de 1964. Apenas em 1970, começou a oferecer o curso de Pedagogia, após a criação de um regimento próprio. A Faculdade abrigou o primeiro prédio da reitoria e os primeiros cursos tiveram disciplinas ministradas nos prédios da FE1, FE3, FE5.

Em 1994, foi inaugurada a primeira turma noturna de Pedagogia, que teve a sua aprovação nas instâncias superiores no ano de 1997 (UNB, 2012). A educação a distância na FE teve início em 1979, com a parceria da faculdade com a Open University com o objetivo da criação da Universidade Aberta do Brasil - UAB. Dessa forma, em 1996, a UnB começou a ofertar o Curso de Especialização em Educação Continuada e a Distância com o apoio da Cátedra Unesco de Educação a Distância e do Ministério da Educação - MEC (Idem).

Após alguns anos, a FE tornou-se o espaço acadêmico não apenas para o curso de Pedagogia, mas também abrigou as demais Licenciaturas que buscam a Faculdade de Educação para realização de disciplinas, como: Didática, Organização da Educação Brasileira, Psicologia da Educação e Políticas de Educação. Por intermédio do Projeto Político Pedagógico, é possível promover "condições formais de aproximação entre as diferentes licenciaturas e consequentemente o desenvolvimento da pesquisa sobre os objetos de ensino" (PARECER CNE n 9/2001, p. 15). Sendo assim, o papel que a Faculdade de Educação deveria ter era o de promover e aproximar as licenciaturas, mas o que se observa é uma separação evidente entre os demais cursos de licenciatura e a Pedagogia, pois disciplinas fundamentais são ofertadas de forma separada para cada um dos cursos.

Hoje a Faculdade de Educação da UnB está organizada em três departamentos: Planejamento e Administração - PAD; Teorias e Fundamentos - TEF; e Métodos e Técnicas - MTC. De acordo com a Minuta do PPP da UnB (2012), o curso de graduação presencial de Pedagogia recebe 602 estudantes no diurno e 339 no noturno.

\subsection{Projeto Acadêmico do Curso de Pedagogia da UnB}

O Projeto Acadêmico do curso de Pedagogia da Faculdade de Educação anterior ao elaborado em 2002, este em análise, entrou em vigor no segundo semestre de 1988. Nesse 
período, o curso tinha como principal objetivo a "introdução da formação no magistério para o ensino fundamental" (UNB 2002, p. 4). Com a resolução no 219/96 do Conselho de Ensino, Pesquisa e Extensão - CEPE, ficou determinado que os créditos em disciplinas obrigatórias não poderiam ultrapassar $70 \%$ do total de créditos do curso. Diante disso, os docentes da Faculdade de Educação decidiram por uma "reformulação profunda" no curso (idem). Conforme Veiga (2008, p. 77), é necessário repensar o currículo de um curso visando ao cotidiano acadêmico,

primeiro, porque sendo descrito, problematizado e compreendido, é possível repensá-lo e propor um projeto pedagógico que possibilite sua reconfiguração. Segundo, porque o cotidiano acadêmico, sendo desvelado e compreendido, propicia a tomada de decisões coletivas e democráticas voltadas para a melhoria da qualidade de ensino.

Desse modo, a decisão de repensar o Projeto Acadêmico do curso de Pedagogia em 1996 pode destacar e problematizar áreas do conhecimento que estavam dispersas, assim como pode repensá-lo de forma coletiva e todos pudessem se sentir parte do processo, apresentando as suas colocações, seus questionamentos e suas necessidades. O processo de tomada de decisões coletivas e de forma democrática auxilia na concretização do Plano, pois todos se sentem responsáveis pela sua efetiva execução.

Além da reivindicação do CEPE, os docentes decidiram pela reformulação do Projeto Acadêmico para atender as exigências da Lei de Diretrizes e Bases - LDB (Lei no 9394/96), dos Parâmetros Curriculares para o Ensino Básico, das Diretrizes Curriculares Nacionais - DCN e das metas fixadas no Plano Nacional de Educação - PNE. O processo de "reformulação curricular teve início em abril de 1997" (UnB 2002, p. 4) tomou como base os textos legais: a LDB 9193/96; o Plano Nacional de Ensino - PNE (Lei 10.172/2001); os Pareceres CNE/CP No 009/2001, 21/2001, 27/2001e 28/2001; e as Resoluções CNE/CP N ${ }^{\circ}$ 1/2002 e 2/2002. Desse modo, como o Projeto Acadêmico do curso de Pedagogia está em vigência até o momento da pesquisa (2015), não foram observadas as alterações apresentadas pelo Conselho Nacional de Educação nos anos de 2005 e 2006, quando foram instituídas novas Diretrizes Curriculares para o curso de graduação em Pedagogia, Licenciatura; deixando, assim, o curso em defasagem em diversos aspectos relevantes, tais como a área de atuação do Pedagogo e o currículo, entre outros.

As questões básicas respondidas naquele momento foram: 
Que objetivos do Curso de Pedagogia persegue hoje? As atuais habilitações devem permanecer como base de organização da formação? O que significa a base docente na formação do pedagogo? Que demandas e inovações devem ser contempladas ao repensar o Curso de Pedagogia na atual conjuntura? (UNB 2002, p. 4)

Essas questões, ao serem analisadas e observadas hoje, podem até mesmo ser desconsideradas, porque, desde o Parecer CNE/CP n ${ }^{\circ}$ 5/2005, não existem mais habilitações no curso de Pedagogia, o que é confirmado no Parecer CNE/CP n 3/2006. Outra questão que é analisada pelo Parecer CNE/CP nº 3/2006 é o que é a docência. Quando reconstruído em 2002, o Projeto Acadêmico do curso da Pedagogia não tinha claro o papel da docência na formação inicial do estudante. Sendo assim, o Parecer de 2006 compreende que a docência é uma ação educativa e um processo pedagógico metódico e intencional, construído por intermédio das relações sociais, as quais influenciam conceitos, princípios e objetivos da ação pedagógica.

De acordo com Veiga (2008, p. 85), a partir da LDB n ${ }^{\circ}$ 9394/96, "as universidades, em particular, vêm desenvolvendo grande esforço para encontrar alternativas de solução a fim de melhorar a formação inicial e continuada de professores de educação básica”. A autora ainda enfatiza a necessidade de que algo precisa ser realizado para o aperfeiçoamento do processo de formação, então cabe a "cada instituição buscar os seus próprios caminhos" (idem). A mudança no Projeto Acadêmico do curso de Pedagogia em 2002 foi a alternativa encontrada pelos docentes da instituição para a adequação necessária às novas exigências da Lei de Diretrizes e Bases da Educação e do CEPE naquele momento, no entanto hoje o Projeto construído em 2002 ainda apresenta muitas lacunas e deficits que prejudicam de forma crucial a formação inicial do Pedagogo.

Uma das visões adotadas na construção do Projeto Acadêmico do Curso de Pedagogia é a visão crítica que entende que o curso de Pedagogia da UnB deve considerar "a formação docente do Pedagogo como essencial mesmo que este não tenha como destino Profissional a atuação como professor" (UnB 2002, p. 5, grifos meus). É objetivo do curso de graduação em Pedagogia formar também o "pesquisador educacional" e o "profissional para participar de projetos em ambiente não escolar" (idem). De acordo com o artigo $4^{\circ}$ das Diretrizes Curriculares Nacionais para o curso de Pedagogia (CNE/CP No 3/2006), o curso de Licenciatura em Pedagogia deverá ser destinado à formação de professores para atuarem na Educação Infantil, nos anos iniciais do Ensino Fundamental; nos cursos de Ensino Médio que ainda apresentem a modalidade Normal; na Educação Profissional; e onde sejam previstos conhecimentos pedagógicos. Sendo assim, a visão adotada pelo Projeto Acadêmico deve ser 
desconstruída, pois a formação do Pedagogo deve ser direcionada, em primeira instância, para atuação na área escolar, não podendo ser secundarizada.

Logo na Justificativa para a mudança do Projeto do Curso, existe uma crítica à rapidez como se tornam obsoletos os conhecimentos, como são obstruídos e como os saberes são despendidos pelo tempo. "Pela primeira vez no curso do desenvolvimento da humanidade, a maioria das competências adquiridas por uma pessoa a iniciar a sua vida profissional se tornará obsoleta bem antes de chegar ao final de sua carreira" (UnB 2002, p. 6). Isso é o que ocorre com algumas disciplinas do curso, pois as tecnologias estão evoluindo com tanta rapidez que o desenvolvimento de informações, no final de um curso de graduação, faz que o conhecimento adquirido não seja mais suficiente para manusear determinado equipamento eletrônico ou até mesmo um conceito estudado seja obsoleto. Apesar de apresentar em seu texto a rapidez como os conhecimentos tornam-se atrasados, o próprio Projeto Acadêmico do curso de Pedagogia está em vigor há 13 anos e muitas leis que o amparam já se tornaram obsoletas há algum tempo. Sendo assim, por que a demora em construir um novo projeto, se as Diretrizes Curriculares Nacionais para o curso de Pedagogia entraram em vigor no ano de 2005? De acordo com informações obtidas na secretaria do curso de graduação em Pedagogia, somente no segundo semestre de 2016, um novo Projeto Acadêmico será apresentado aos estudantes e, por enquanto, apenas alguns debates estão sendo realizados para a sua construção.

Deve-se destacar que esse Projeto define que os aprendizados deveriam ser "personalizados" e "cooperativos em rede", pois o "docente é chamado a tornar-se um mobilizador da inteligência coletiva de seus grupos de alunos" (UnB 2002, p. 7). Observa-se hoje que essa medida não conseguiu ser implementada duramente a vigência do Projeto Acadêmico de Curso; o aprendizado é fragmentado; e não existe uma troca entre as disciplinas cursadas pelo estudante. Nesse Projeto Acadêmico, o professor também foi orientado a acompanhar e gerenciar os aprendizados dos estudantes, realizando, para isso, uma mediação em suas aprendizagens. Essa estratégia foi pouco aprofundada na vigência do Projeto de curso. O que ocorre é a orientação dos professores na fase de elaboração do trabalho de conclusão de curso - TCC, apenas.

A base teórica- metodológica adotada para a concretização das mudanças no Projeto Acadêmico do Curso de Pedagogia está baseada na Pedagogia da Complexidade, que é "capaz de dar abrigo à multiplicidade de referências existentes" (UnB 2002, p. 8). Ela está embasada no pensamento do autor Edgar Morin e tem dimensão essencialmente interativa e dialógica. Conforme Veiga (2008, p. 92), na construção do Projeto Político Pedagógico, é 
necessário "delimitar um referencial teórico-metodológico na condução dos projetos pedagógicos dos cursos" responsáveis pela condução dos trabalhos, pois, através desse referencial, será possível identificar os possíveis rumos que o currículo da instituição poderá adotar. O Projeto Acadêmico torna-se ambíguo ao criar um tópico sobre a sua opção teóricometodológico, pois, no início do texto, o escritor informa que está partindo de uma visão crítica (UNB, 2002, p. 5), em seguida traz como base a pedagogia da complexidade (UNB, 2002, p. 8). Afinal, qual visão é adotada no curso de Pedagogia da Universidade de Brasília? Existe uma miscelânea de ideias apresentadas por ambas as visões. Em alguns pontos existe convergência entre essas teorias, mas, em determinados momentos, elas se distanciam.

O curso de Pedagogia da Universidade de Brasília tem a missão

(...) de formar educadores capazes de intervir na realidade, através de uma atuação profissional crítica, contextualizada, criativa, ética, coerente e eficaz, buscando a plena realização individual e coletiva. Esta atuação deve, complementarmente, estar comprometida com um projeto de sociedade autônoma, solidária e democrática (UNB 2002, p. 9).

A missão do curso de Pedagogia está em parte em consonância com o almejado pela Diretriz Curricular Nacional para o curso de Pedagogia CNE/CP n³/2006, a qual entende que a consolidação desses conhecimentos será propiciada pelo exercício profissional, os quais também devem estar em conexão com o princípio da interdisciplinaridade e da sensibilidade afetiva e estética. Da mesma forma, deve ser missão do curso de Pedagogia o entendimento do estudante de que a escola é uma organização complexa e a sua função primordial é uma educação para a cidadania.

\subsubsection{Currículo do Curso de Pedagogia}

O currículo do curso de Pedagogia foi construído como "algo aberto e em movimento" (UNB, 2002, p. 10) que possibilita a inserção do estudante em diversos percursos e privilegia os resultados alcançados. Essa possibilidade de que o estudante siga variados caminhos proporciona uma diversificação de trajetórias para ele percorrer durante o seu curso. Essa "proposta curricular permite inicialmente a transição de uma fase de vida para outra, enriquecendo e dando sentido à escolha para a carreira de pedagogo" (UNB, 2002, p. 11). Podemos definir o currículo do curso como uma "teia com contornos bem definidos" (idem) que determinam a formação inicial desse estudante. Após a inserção do discente do curso de 
Pedagogia no mundo do trabalho, neste momento, ele é levado a "fazer uma opção quanto ao seu futuro profissional" e possivelmente traçar caminhos a serem seguidos durante o seu percurso acadêmico.

O Projeto Acadêmico do curso de Pedagogia apresenta que o curso tem um fluxo curricular e a justificativa para o uso deste é a necessidade de enfatizar o conceito de "fluidez, de flexibilidade, de roteiro orientador" (UNB, 2002, p. 11), o que tira o caráter de aprisionamento da palavra grade. No fluxo são apresentados ao estudante diversos conteúdos de estudo que também podem ser denominados de áreas. Dentro desse estudo, deve-se buscar um equilíbrio entre a obrigatoriedade e a liberdade, sendo assim, "alguns estudos se impõem, excluindo outros" (Idem).

O Projeto Acadêmico do curso de Pedagogia ressalta que, por meio do fluxo, buscou-se assegurar um conteúdo mínimo de componentes obrigatórios que remetem às Ciências Pedagógicas, às Ciências da Educação e aos estudos de ordem organizacional e administrativa. O quadro de fluxo curricular do curso de Pedagogia encontra-se no Anexo I deste trabalho.

As disciplinas obrigatórias do curso são: Antropologia e Educação; Perspectiva do Desenvolvimento Humano; Projeto 1; Organização da Educação Brasileira; História da Educação; Pesquisa em Educação 1; O Educando com Necessidades Educacionais Especiais; Projeto 2; Psicologia da Educação; Ensino e Aprendizagem da Língua Materna; Ensino de Ciência e Tecnologia 1; Aprendizagem e Desenvolvimento do Portador de Necessidades Educacionais Especiais; Projeto 3 - fase 1; Educação Matemática 1; Sociologia da Educação; Orientação Educacional; Didática Fundamental; Projeto 3 - fase 2; História da Educação Brasileira; Administração das Organizações Educativas; Processo de Alfabetização; Políticas Públicas de Educação; Educação e Geografia; Orientação Vocacional/Profissional; Projeto 4 fase 1; Filosofia da Educação; Ensino de História; Identidade e Cidadania; Projeto 4 - fase 2; Avaliação das Organizações Educativas; e Projeto 5 - Trabalho de Final de Curso.

Essas disciplinas formam a base curricular do curso de Pedagogia da Universidade de Brasília. Esse fluxo apresentado é diferente do proposto pelas Diretrizes Curriculares Nacionais - DCN para o curso de Pedagogia de 2006. Nessa DCN (2006), é proposto que o currículo seja constituído de três núcleos: núcleo de estudos básicos; núcleo de aprofundamento e diversificação de estudos; e núcleo de estudos integradores. O núcleo de estudos básicos será responsável por articular a aplicação, os princípios, as concepções e os critérios das diversas áreas do conhecimento com o campo da Pedagogia; assim como da gestão democrática em espaços escolares e não escolares; dos processos de desenvolvimento 
da criança, do adolescente e do adulto em todas as suas áreas; observação, análise, planejamento, implementação e avaliação de processos educativos; conhecimento acerca de situações de aprendizagem; diagnóstico a respeito das necessidades do indivíduo nos planos pedagógicos de ensino aprendizagem; análises de experiências na Educação Infantil e na formação de professores; estudo da Didática; decodificação e utilização de diferentes códigos nos conteúdos pertinentes aos primeiros anos de escolarização; estudo de problemáticas contemporâneas; atenção às questões éticas, estéticas e ludicidade no contexto profissional; e aplicação de textos legais relativos à educação nacional (CNE/CP nº 3/2006).

O núcleo de aprofundamento e diversificação de estudos é voltado para a área de atuação profissional proposto pelos projetos pedagógicos de cada instituição. Sendo assim, nessa área, serão investigados processos educativos e gestoriais em diferentes situações institucionais: "escolares, comunitárias, assistenciais, empresariais e outras" (CNE/CP 3/2006, p. 4); avaliação, criação e uso de textos em processos de aprendizagem que observem a diversidade social e cultural brasileira; e estudos das teorias educacionais, com o objetivo de elaborar propostas educacionais consistentes e inovadoras.

No núcleo de estudos integradores, o objetivo principal é o enriquecimento curricular. Sendo assim, a sua finalidade é a participação em seminários e estudos curriculares, em projetos de iniciação científica, extensão e monitoria, sempre orientada pelo corpo docente; atividades práticas com o intuito de experimentar vivências variadas no campo educacional; e atividades de comunicação e expressão cultural.

Desse modo, as disciplinas do curso de Pedagogia da Universidade de Brasília atendem apenas em parte os requisitos propostos pelas Diretrizes Curriculares Nacionais para o curso, porque porta em seu fluxo curricular disciplinas obrigatórias, que estariam dentro do núcleo básico, mas o núcleo de aprofundamento e diversificação de estudos fica prejudicado, pois, mesmo que a Universidade apresente em seu fluxo que existem as disciplinas optativas, o estudante não é orientado na hora de escolhê-las. Muitos não conseguem começar um estágio nos primeiros semestres de graduação, porque o fluxo curricular e a maneira como as disciplinas são dispostas nos mais variados horários não permitem que o discente possa reservar tempo para a sua prática acadêmica. Sendo assim, não possuindo uma orientação prévia, nem um interesse anterior, o estudante fica sujeito a optar por qualquer disciplina, mesmo que não tenha ligação com a sua área de interesse. O que poderia ser realizado é a oferta de matérias optativas, e o estudante escolheria um fluxo pré-fixado de disciplinas que o levariam a uma formação voltada para a atuação na Educação Infantil e nos anos iniciais do Ensino Fundamental. 
É importante destacar que as Diretrizes Curriculares para o curso de Pedagogia preveem uma carga horária mínima de 3200 horas de efetivo trabalho acadêmico que podem ser distribuídas em: $2800 \mathrm{~h}$ de atividades formativas; $300 \mathrm{~h}$ de estágio supervisionado prioritariamente em Educação Infantil e anos iniciais do Ensino Fundamental; e 100 horas de atividades teórico-práticas como iniciação científica, extensão e monitoria (CNE/CP 3/2006). O curso de Pedagogia da UnB oferece aos seus estudantes 2100 horas de disciplinas obrigatórias e 1110 horas de disciplinas optativas. Apesar de oferecer um considerável número de horas de disciplinas obrigatórias o curso peca em proporcionar mais de 1000 horas de carga horária em disciplinas optativas, as quais os estudantes ficam buscando, de disciplina em disciplina, créditos para poder se formarem, muitas vezes procuram disciplinas de "crédito fácil”, desvinculadas da área da educação e que, em inúmeros casos, não agregam valor à formação inicial do futuro professor de anos iniciais.

Por meio do Projeto 4 - fases 1 e 2, o estudante de Pedagogia da Universidade de Brasília é direcionado ao Estágio Supervisionado. Cada uma das etapas do projeto possui uma carga horária de 120 horas, totalizando 240 horas de estágio. Essa quantidade de horas é inferior à recomendada pelas DCNs para o curso de Pedagogia, para o qual são previstas “300 horas dedicadas ao Estágio Supervisionado prioritariamente em Educação Infantil e nos anos iniciais do Ensino Fundamental, contemplando também outras áreas específicas, se for o caso, conforme o projeto pedagógico da instituição" (CNE/CP 3/2006, p. 4). A redução da carga horária no estágio prejudica a prática pedagógica do graduando em Pedagogia e limita a sua experiência e a vivência em sala de aula, pois é apenas por meio de situações do dia a dia em sala de aula que o estudante será capaz de formular e consolidar conhecimentos aprendidos teoricamente e colocá-los em prática.

Por meio do Projeto Acadêmico de Curso, é criada, no fluxo curricular do curso de Pedagogia da UnB, a inserção de Projetos que perpassam todo o percurso acadêmico do estudante. Os Projetos têm por objetivo formar um fio condutor que levará o aluno desde o início da sua graduação até o seu trabalho de final de curso. Será por intermédio dos Projetos que o estudante terá "atividades orientadas, de observação, de regência, de investigação, de extensão, de busca bibliográfica, e tendo como referência a vida concreta das organizações, onde os fatos e as situações educativas acontecem" (UnB, 2002, p. 12). Os Projetos foram construídos visando a uma "autêntica formação prático-teórica" (Idem). Eles se classificam da seguinte forma:

Projeto 1- Orientação Acadêmica Integral (OAI)

Projeto 2- Grupo de Estudos e/ou Projeto de Ensino/Pesquisa/Extensão (GEPE) 
Projeto 3: fase 1 - Projeto ou Subprojetos Individualizados (PESPE)

Projeto 3: fase 2 - Idem

Projeto 3: fase 3 - Idem (Optativo)

Projeto 4: fase 1 - Subprojeto Individualizado de Prática Docente (SPEPD)

Projeto 4: fase 2 - Idem

Projeto 5: fase 1 - Trabalho Final de Curso (TFC)

Projeto 5: fase 2 - Em processo de criação

Os Projetos perpassam a vida acadêmica do estudante ao longo dos oito semestres na Universidade. O Projeto 1 tem por objetivos acolher o estudante; inseri-lo no contexto da Faculdade de Educação; e mostrar a profissão de Pedagogo e as suas possibilidades de trabalho. Os Projetos 2 e 3 são destinados ao estudante para ele escolher a área temática de interesse e aprofundar-se nela. O Projeto 4 é reservado ao Estágio Supervisionado e o Projeto 5 ao Trabalho de Final de Curso. Observa-se é que a prática existe apenas no Projeto 4 - fases 1 e 2. Desse modo, fica evidente que o estágio apenas nestes momentos não consegue suprir a necessidade de prática do estudante de graduação em Pedagogia. Das fases do Projeto, em apenas duas o estudante vai a campo observar as situações das organizações educativas.

Concordando com Veiga (2008, p. 97), deve-se

colocar a prática profissional como um dos focos centrais da formação do professor, tanto para a formação inicial como para a formação continuada uma prática mais efetiva, proporcionada ao longo do processo de formação e não apenas no final dele, quando a maioria dos conteúdos já foram estudados.

A prática ao longo do percurso acadêmico oferecer benefícios ao estudante, pois ele pode entrar em contato com diversas situações pedagógicas, analisá-las à luz da teoria e colocar em prática os conhecimentos adquiridos em sala de aula, consolidando assim o aprendido e até mesmo repensando práticas e comportamentos.

\subsection{Análise do Projeto Acadêmico do curso de Pedagogia da UnB de acordo com o Instrumento de Avaliação de Cursos de Graduação- presencial e a distância de agosto de 2015}

Para esta análise, será utilizado o Instrumento de Avaliação de Cursos de Graduação - presencial e a distância, elaborado pelo Ministério da Educação juntamente com o Instituto Nacional de Estudos e Pesquisas Educacionais Anísio Teixeira - INEP, de agosto 
de 2015. Esta análise tem o objetivo de analisar o Projeto Acadêmico do curso de Pedagogia da UnB de 2002 vigente até $2016^{3}$. A cada indicador analisado, foi apresentada uma nota de 1 a 5; sendo considerados 1, para "não existe"; até 5, para "excelente". Em seguida, existe a justificativa para o conceito atribuído a cada indicador.

Tabela 2 - Critérios de análise segundo o INEP

\begin{tabular}{|l|l|}
\hline Conceito & \multicolumn{1}{|c|}{ Descrição } \\
\hline 1 & $\begin{array}{l}\text { Quando os indicadores de dimensão avaliada configuram um conceito NÃO } \\
\text { EXISTENTE }\end{array}$ \\
\hline 2 & $\begin{array}{l}\text { Quando os indicadores de dimensão avaliada configuram um conceito } \\
\text { INSUFICIENTE }\end{array}$ \\
\hline 3 & $\begin{array}{l}\text { Quando os indicadores de dimensão avaliada configuram um conceito } \\
\text { SUFICIENTE }\end{array}$ \\
\hline 4 & $\begin{array}{l}\text { Quando os indicadores de dimensão avaliada configuram um conceito MUITO } \\
\text { BOM/MUITO BEM }\end{array}$ \\
\hline 5 & $\begin{array}{l}\text { Quando OS indicadores de dimensão avaliada configuram um conceito } \\
\text { EXCELENTE }\end{array}$ \\
\hline
\end{tabular}

\section{Indicadores:}

Dimensãol: Organização didático- pedagógica

\section{1 - Contexto educacional}

Conceito 1 - Quando o PPC não contempla as demandas efetivas de natureza econômica, social, cultural, política e ambiental.

Justificativa: Não é apresentado no Projeto Acadêmico do curso de Pedagogia nada que contemple o contexto educacional em que o curso da Universidade de Brasília está inserido. Não há nada da história do curso, da economia local, da cultura, da política ou do ambiente.

\section{2- Políticas institucionais no âmbito do curso}

Conceito 1 - Quando as políticas institucionais de ensino, de extensão e de pesquisa (esta última, quando for o caso) constantes no PDI estão previstas/implementadas no âmbito do curso.

Justificativa: Em nenhum momento no Projeto Acadêmico de curso é contemplado um tópico referente à previsão e à implementação de políticas institucionais de ensino, extensão e pesquisa.

${ }^{3}$ Deve-se ressaltar que já existe um Projeto Acadêmico de Curso a ser implementado no segundo semestre de 2017 e alguns núcleos já estão trabalhando para a concretização do mesmo. 


\section{3- Objetivos do curso}

Conceito 3 - Quando os objetivos do curso apresentam suficiente coerência, em uma análise sistêmica e global, com os aspectos: perfil profissional do egresso, estrutura curricular e contexto educacional.

Justificativa: O Projeto Acadêmico da Pedagogia da Universidade de Brasília apresenta como objetivos do curso:

- Formar profissionais capazes de articular o fazer e o pensar pedagógicos para intervir nos mais diversos contextos socioculturais e organizacionais que requeiram sua competência;

- Formar profissionais conscientes de sua historicidade e comprometidos com os anseios de outros sujeitos, individuais e coletivos, socialmente referenciados para formular, acompanhar e orientar seus projetos educativos;

- $\quad$ Preparar educadores capazes de planejar e realizar ações e investigações que os levem a compreender a evolução dos processos cognitivos, emocionais e sociais considerando as diferenças individuais e grupais, e

- Formar profissionais comprometidos com seu processo de autoeducação e de formação continuada.

Alguns dos objetivos estão diluídos ao longo do Projeto do curso quando são tratadas as disciplinas, no perfil do egresso do curso de Pedagogia e nas opções teóricometodológicas. O que não fica claro para o leitor do projeto é o último objetivo do curso de "formar profissionais comprometidos com o seu processo de autoeducação e de formação continuada". Existe um tópico no Projeto acerca da formação continuada, mas fica claro que ela só acontecerá, se existir "capacidade de a Universidade de Brasília e a Faculdade de Educação conseguir ter um quadro docente com a diversificação necessária, bem como da capacidade de trabalho interdisciplinar de seus docentes" (UNB, 2002, p. 14). Sendo assim, a UnB só apresentará cursos em nível de pós-graduação lato sensu, se possuir em seu quadro de profissionais um número qualificado de pessoas que possam atuar interdisciplinarmente nos cursos a serem ofertados. Não é evidenciada, em nenhum momento, a autoeducação para os estudantes ou o comprometimento de o professor incentivar essa autoformação. A Faculdade de Educação oferece o programa de Pós-Graduação sirito em nível de mestrado e doutorado.

\section{4- Perfil profissional do egresso}

Conceito 2 - Quando o perfil profissional expresso, de maneira insuficiente, as competências do egresso. 
Justificativa: O Projeto do curso de Pedagogia se apresenta de maneira insuficiente acerca do perfil do egresso do curso; eles e limita a relatar que entende que, em muitas vezes, o destino do profissional não é a sala de aula. Então pretende-se formar o pesquisador educacional e o profissional qualificado para participar de projetos de formação em ambientes não escolares, e essa formação seria em base teórica, científica e técnica.

1.5- Estrutura curricular (Considerar como critério de análise a pesquisa e a extensão, caso sejam contempladas no PPC).

Conceito 4 - Quando a estrutura curricular prevista/implementada contempla, muito bem, em uma análise sistêmica e global, os aspectos: flexibilidade, interdisciplinaridade, acessibilidade pedagógica e atitudinal, compatibilidade da carga horária total (em horas), articulação da teoria com a prática e, nos casos de cursos a distância, mecanismos de familiarização com essa modalidade.

Justificativa: O Projeto Acadêmico do curso de Pedagogia apresenta um fluxo curricular, ao invés de grade horária, porque esta conota aprisionamento. Esse fluxo tem o objetivo de apresentar fluidez, flexibilidade no curso. O currículo é delimitado por três polos: 1) das práxis, responsável pela vivência da prática educativa e alimentada pelos Projetos; 2) da formação pedagógica, que permite o exercício da função docente no início da escolarização; e 3) da Ciência da Educação, que oferece ao estudante os marcos teóricos e conceituais. Por meio dos Projetos 1, 2, 3, 4, e 5, é "autêntica [a] formação prático-teórica" (UNB, 2002, p. 12).

É apresentado, na missão e princípios do curso, que é possível ver a Educação como um processo continuado e interdisciplinar, no qual são preservadas as qualidades acadêmicas e indissociadas da extensão, da pesquisa e do ensino.

No curso de Pedagogia da UnB, são oferecidas 2100 horas de disciplinas obrigatórias e 1110 horas de disciplinas optativas, totalizando, assim, 3210 horas de disciplinas. É oferecido ao estudante 240 horas de Projeto 4, fases 1 e 2 , o qual se refere ao Estágio Supervisionado. Desse modo, de acordo com as Diretrizes Curriculares Nacionais para o curso de Pedagogia (CNE/CP No 3/2006) é ofertada uma quantidade maior de disciplinas para o curso de Pedagogia, sendo recomendadas 2800 horas de atividades formativas e um número menor de Estágio Supervisionado, para o qual o recomendado seriam 300 horas. 


\section{6- Conteúdos curriculares}

Conceito 2 - Quando os conteúdos curriculares previstos/implementados possibilitam, de maneira insuficiente, o desenvolvimento do perfil profissional do egresso, considerando, em uma análise sistêmica e global, os aspectos: atualização, acessibilidade, adequação das cargas horárias (em horas), adequação da bibliografia, abordagem de conteúdos pertinentes às políticas de educação ambiental, de educação em direitos humanos e de educação das relações étnico-raciais e para o ensino de história e cultura afro-brasileira, africana e indígena.

Justificativa: O currículo do curso de Pedagogia da Universidade de Brasília apresenta um considerável rol de matérias em seu fluxo, mas elas ainda não conseguem atender com eficácia e eficiência aos estudantes do curso, porque $50 \%$ dele é formado por disciplinas optativas. Apesar de apresentar uma variedade elevada dessas disciplinas, o estudante não focaliza seu curso em nenhuma área, pois o caminho se torna muito aberto e flexível, o que impede de o aluno não cursar disciplinas que deveriam ser obrigatórias, como: educação infantil e educação de adultos, entre outras.

Não existe uma especificação dentro do currículo acerca de quais matérias serão incluídos os conteúdos de educação ambiental, de educação em direitos humanos, educação das relações étnico-raciais e para o ensino de história e cultura afro-brasileira, africana e indígena. Também não é apresentado, em nenhum momento do currículo, quais as bibliografias ou as adequações bibliográficas serão realizadas para a implementação desses conteúdos.

\section{7- Metodologia}

Conceito 2 - Quando as atividades pedagógicas apresentam insuficiente coerência com a metodologia prevista/implantada, inclusive em relação aos aspectos referentes à acessibilidade pedagógica e atitudinal.

Justificativa: O Projeto Acadêmico do curso de Pedagogia destaca que adota a metodologia da Pedagogia da Complexidade. Essa concepção teórica tem suporte teórico no autor Edgar Morin, o qual entende que se deve perceber o homem como um ser humano total. Essa concepção prevê uma reforma do pensamento, inclusive o científico. Entende que deve haver uma dimensão interativa e dialógica, sempre centrada no ser humano, e fazer dele a razão e o sentindo da atividade educativa. 
Essa metodologia em parte é adequada ao Projeto Acadêmico, pois apenas é visível essa dimensão do ser humano nos Projetos 1, 2, 3, 4 e 5. Essa reforma do pensamento não é percebida com clareza na apresentação das disciplinas do curso nem em seus objetivos.

\section{8- Estágio curricular supervisionado}

Conceito 2- Quando o estágio curricular supervisionado previsto/implantado está regulamentado/institucionalizado de maneira insuficiente, considerando, em uma análise sistêmica e global, os aspectos: carga horária, previsão/existência de convênios, formas de apresentação, orientação, supervisão e coordenação.

Justificativa: Ao que se refere ao estágio supervisionado, não existe uma clareza no Projeto Acadêmico do curso de Pedagogia. É apenas expresso que, por meio dos Projetos 1, 2, 3, 4 e 5, ocorre uma articulação entre a teoria e a prática. Apenas no anexo do Projeto Acadêmico é apresentado que o estágio supervisionado está reservado ao Projeto 4, fases 1 e 2, totalizando, assim, dois semestres de prática, com a previsão de $120 \mathrm{~h}$ para cada uma dessas fases.

Ao final, o estudante terá realizado apenas 240 horas de estágio supervisionado, um número de horas inferior à prevista nas Diretrizes Curriculares Nacionais para o curso de Pedagogia (CNE/CP N 3/2006) que prevê uma carga horária de 300 horas de prática.

Em nenhum momento, é expresso no Projeto Acadêmico como serão realizadas a forma de apresentação do estágio e as orientações para a sua execução, nem como ocorrerá a sua supervisão e a coordenação. Também não é informado se existem convênios com instituições de ensino que acolham os estágios supervisionados.

1.9- Estágio curricular supervisionado - relação com a rede de escolas da Educação Básica

Conceito 1 - Quando o estágio curricular supervisionado previsto/implementado não está regulamentado/institucionalizado.

Justificativa: Não existe nada no Projeto Acadêmico referente à previsão de convênios à forma de apresentação, orientação, supervisão, avaliação e coordenação dos estágios supervisionados.

1.10- Estágio curricular supervisionado - relação entre licenciados, docentes, supervisores da rede de escolas da Educação Básica 
Conceito 1- Quando o estágio curricular supervisionado previsto/implementado não está regulamentado/institucionalizado.

Justificativa: Não existe nada previsto no Projeto Acadêmico do curso de Pedagogia da UnB ao respeito do estágio supervisionado. Não há informações de como será a supervisão do estágio e o acompanhamento/participação do licenciado nas atividades de planejamento, desenvolvimento e avaliação realizada pelos docentes da Educação Básica. Também não esclarece como será a participação dos docentes da Educação Básica no processo de orientação/formação dos licenciados.

\subsection{1- Estágio curricular supervisionado - relação teoria e prática}

Conceito 1- Quando o estágio curricular supervisionado previsto/implementado não está regulamentado/institucionalizado.

Justificativa: Não existe no Projeto Acadêmico do curso suportes para o estágio supervisionado.

\subsection{2- Atividades complementares}

Conceito 1 - Quando as atividades complementares previstas/implementadas não estão regulamentadas/institucionalizadas.

Justificativa: Não existe nenhuma regulamentação no Projeto Acadêmico do curso de Pedagogia da UnB para as atividades complementares.

\subsection{3- Trabalho de Conclusão de Curso (TCC)}

Conceito 1 - Quando o Trabalho de Conclusão de Curso previsto/implementado não está regulamentado/institucionalizado.

Justificativa: Apenas existe no Projeto Acadêmico do curso que o TCC deve possuir uma carga horária de 120 horas. Não Há nenhuma outra orientação relativa à execução, à elaboração e à avaliação do Trabalho Final de Curso.

\subsection{4- Apoio ao discente}

Conceito 1 - Quando não existe programa de apoio ao discente previsto ou implementado.

Justificativa: Não foi localizado no Projeto Acadêmico nenhuma informação a respeito de atividades de apoio ao estudante. 
1.15- Ações decorrentes dos processos de avaliação do curso

Não foi possível obter os dados referentes a avaliações realizadas do curso por intermédio da secretaria da graduação da Pedagogia.

\subsection{6- Atividades de Tutoria}

Não se aplicam a cursos presenciais.

1.17- Tecnologias de Informação e Comunicação - TICs- no processo de ensinoaprendizagem

Conceito 3 - Quando as Tecnologias de Informação e Comunicação (TICs) previstas/implementadas no processo de ensino-aprendizagem permitem, de maneira suficiente, a execução do projeto pedagógico do curso e a garantia da acessibilidade e do domínio das TICs.

Justificativa: No Projeto Acadêmico do curso de Pedagogia, está previsto que as Tecnologias de Informação e Comunicação devem permear todo o curso e isto deve ser realizado em todos os espaços curriculares. Também devem ser oferecidas as oficinas de comunicação e tecnologia, assim como a vivência das tecnologias interativas on-line.

1.18 e 1.19 - Material didático institucional e Mecanismos de interação entre docentes, tutores e estudantes.

Esses itens não se aplicam aos cursos presenciais.

1.20- Procedimentos de avaliação dos processos de ensino-aprendizagem

Conceito 5- Quando os procedimentos de avaliação previstos/implementados utilizados nos processos de ensino- aprendizagem atendem, de maneira excelente, a concepção do curso definida em seu Projeto Pedagógico de Curso - PPC.

Justificativa: Levando em consideração que o Projeto Acadêmico do curso de Pedagogia adota como referencial teórico-metodológico a Pedagogia da Complexidade, o seu Projeto atende com eficácia e eficiência os conceitos de entender o ser humano como um todo. A utilização de diversos instrumentos para avaliar a aprendizagem demonstra essa visão.

É utilizada a autoavaliação tanto do discente quanto do docente. Também são utilizadas as avaliações tradicionais que verificam a inteligência linguística e a lógicomatemática. O Projeto apresenta que devem ser levadas em consideração as múltiplas 
inteligências e também devem ser elaborados instrumentos justos para a avaliação dessas aprendizagens.

1.21- Número de vagas

Conceito 1 - Quando o número de vagas previstas/implementadas não corresponde à dimensão do corpo docente e às condições de infraestrutura da IES.

Justificativa: Não existia um conceito adequado para esta questão, pois não o Projeto Acadêmico do curso de Pedagogia não previa o quantitativo de vagas ofertadas por semestre, nem a quantidade de docentes que a instituição FE possui. Há ausência de quadro docente.

1.22- Integração com as redes públicas de ensino

Conceito 1- Quando não existem ações ou convênios que promovam a integração com as escolas da educação básica das redes públicas de ensino.

Justificativa: Não está expresso no Projeto Acadêmico de curso uma parceria ou convênio com nenhuma instituição, nem mesmo com a rede pública de ensino.

1.23, 1.24, 1.25, 1.26 - Não se aplicam à área de Educação, apenas para cursos na área de saúde.

1.27- Atividades práticas de ensino para Licenciaturas

Conceito 1 - Quando não estão previstas/implementadas atividades práticas de ensino conforme as Diretrizes Curriculares Nacionais.

Justificativa: O Projeto Acadêmico do curso de Pedagogia da UnB não prevê em seu documento práticas de ensino, contrariando, assim, a nova legislação que sugere mais atividades práticas.

\section{Dimensão 2: Corpo Docente e Tutorial}

2.1- Atuação do Núcleo Docente Estruturante - NDE

Conceito 1- Quando o NDE não está previsto/implementado.

Justificativa: Entende-se, de acordo com o Instrumento de Avaliação dos cursos de Graduação (INEP, 2005), que o Núcleo Docente Estruturante é um conjunto de professores, composto por pelo menos cinco professores de elevada formação e titulação que 
respondem mais diretamente pela concepção, implementação e consolidação do Projeto Pedagógico do Curso.

Não existe expresso no Projeto Acadêmico da Pedagogia este conjunto de professores responsáveis por essa implementação.

\section{2- Atuação do(a) coordenador(a)}

Conceito 5- Quando a atuação do(a) coordenador(a) é excelente, considerando, em uma análise sistêmica e global, os aspectos: gestão do curso, relação com os docentes e os discentes e representatividade nos colegiados superiores.

Justificativa: É previsto pelo Projeto Acadêmico do curso de Pedagogia que os Coordenadores de curso são responsáveis pela supervisão das ofertas de disciplinas; pela análise dos programas de estudo propostos pelos diferentes docentes; pela representação nos colegiados da Faculdade de Educação, bem como na Câmara de Graduação e CEPE, entre outros.

Também é previsto que o coordenador seja responsável pela organização de um fórum permanente de orientação, além de acompanhar cada estudante de forma individualizada, com arquivos pessoais, nos quais deve registrar o desenvolvimento acadêmico e formativo de cada estudante.

2.3, 2.4, 2.5, 2.6, 2.7, 2.8, 2.9, 2.10, 2.11, 2.12 - Não é informado quem é o professor responsável pela coordenação do curso, nem a sua experiência no magistério superior ou dados relativos ao regime de trabalho no Projeto Acadêmico. Também não aparecem dados, como: carga horária, titulação do corpo docente, regime de trabalho, experiência profissional, experiência na educação básica e superior, e dados acerca da relação entre o número de docentes e as vagas.

\subsection{3- Funcionamento do colegiado de curso ou equivalente}

Conceito 2- Quando o funcionamento do colegiado previsto/implementado está regulamentado/institucionalizado, de maneira insuficiente, considerando, em uma análise sistêmica e global, os aspectos: representatividade dos segmentos, periodicidade das reuniões, registros e encaminhamento das decisões.

Justificativa: É apresentado no Projeto Acadêmico do curso de Pedagogia que o coordenador de curso é responsável por representar a Faculdade de Educação nos colegiados e nas Câmaras de Graduação, assim como no CEPE. Não é evidenciado em nenhum momento a 
periodicidade dessas reuniões, assim como são realizados os registros e encaminhamento das decisões.

2.14, 2.15, 2.16, 2.17, 2.18, 2.19, 2.20 - Não se aplicam ao curso de graduação em Pedagogia presencial, apenas em cursos de educação à distância. Não foi objetivo da análise do curso na perspectiva do Instrumento de Avaliação de cursos de graduação do INEP emitir um conceito, mas apresentar os conceitos positivos e as fragilidades.

\section{Dimensão 3 - Infraestrutura}

A análise referente à dimensão 3, infraestrutura, não pôde ser realizada, pois o Projeto Político Pedagógico do curso de Pedagogia da UnB não contempla essas informações e alguns dos itens não se aplicam ao curso.

\subsection{Análise das Ementas das Disciplinas sobre Educação Especial}

De acordo com o Projeto de Curso de Dezembro de 2002, o curso de Pedagogia da Universidade de Brasília apresenta três disciplinas como obrigatórias na área de Educação Especial: "O Educando com Necessidades Educacionais Especiais", "Aprendizagem e Desenvolvimento do PNEE" e "Libras". Essas disciplinas estão vinculadas ao departamento de Teorias e Fundamentos - TEF, da Faculdade de Educação. Foram analisadas as Ementas das disciplinas a respeito da Educação Especial que foram disponibilizadas pela secretaria do curso de graduação em Pedagogia.

O Projeto Acadêmico do curso de Pedagogia, em nenhum de seus capítulos, especifica as competências de cada área de concentração. Assim, essa omissão impede que o estudante saiba os domínios que deve desenvolver em cada área de estudo, o que deixa vagas as competências que o estudante optante por Educação Especial deva possuir ao final do curso.

\subsubsection{O Educando com Necessidades Educacionais Especiais}

A disciplina "O Educando com Necessidades Educacionais Especiais" é uma matéria obrigatória do curso de graduação em Pedagogia da Universidade de Brasília.Ela está inserida no fluxograma no segundo período do curso, tendo um total de quatro créditos e uma 
carga horária semestral de 60h. Não apresenta disciplinas como pré-requisito e seu código é 197947 (UnB, 2002).

De acordo com a sua ementa, essa disciplina tem por objetivos analisar o contexto histórico, social, político, cultural e educacional em que o ensino especial está inserido; compreender o conceito de diversidade e as categorias de necessidades educacionais especiais para o devido atendimento aos alunos com deficiência; compreender as dificuldades de aprendizagem e outras minorias da realidade da escola inclusiva. Também deve analisar as especificidades educacionais e as potencialidades desses alunos, além do papel e da preparação do professor (UNB, 2015).

A bibliografia apresentada para a disciplina condiz com os seus objetivos de análise, entendimento e preparação do professor que atuará com a Educação Especial e Inclusiva. A bibliografia básica engloba os mais importantes documentos referentes ao tema, tais como, os Parâmetros Curriculares Nacionais: Adaptações Curriculares; as Diretrizes Nacionais para a Educação Especial na Educação Básica: a Declaração da Guatemala; a Declaração de Salamanca; e a Declaração Mundial de Educação para todos, entre outros. Não foram observados na bibliografia autores que trabalham a formação de professores para a Educação Especial e Inclusiva.

$\mathrm{Na}$ ementa também é apresentado ao estudante um programa que divide a disciplina em três unidades: Unidade 1- Educação Especial; Unidade 2 - Educação Inclusiva; e Unidade 3 - Necessidades Educacionais Especiais e Prática Pedagógica. Esse tripé oportuniza ao estudante para que tenha uma noção básica a respeito das necessidades que um estudante com deficiência tem e, de maneira inicial, como pode ser a sua atuação com ele em sala de aula. Com a carga horária de 60 horas, não é possível que tais conceitos sejam debatidos com profundidade nem aprendidos de maneira satisfatória.

\subsubsection{Aprendizagem e Desenvolvimento do PNEE}

A disciplina obrigatória "Aprendizagem e Desenvolvimento do Portador de Necessidades Educacionais Especiais", de acordo com o fluxo curricular de Pedagogia, deve ser ministrada no terceiro período de curso e apresenta como pré-requisito a disciplina " $\mathrm{O}$ Educando com Necessidades Educacionais Especiais". Tem o total de quatro créditos, uma carga horária de 60h semestrais e seu código é 193283. 
A disciplina tem por objetivo o estudo do desenvolvimento e da aprendizagem das pessoas com necessidades educacionais especiais, visando a propostas educacionais. Ela tem por característica conhecer as diferentes perspectivas históricas da aprendizagem e do desenvolvimento das pessoas com deficiência, com o objetivo de uma análise crítica do contexto socioeducacional. Segundo a ementa, a disciplina pretende "compreender o processo de desenvolvimento das pessoas com necessidades educacionais especiais, como forma específica do desenvolvimento humano; compreensão dos principais fatores que interferem na aprendizagem das pessoas com necessidades educacionais especiais” (UnB, 2015).

A disciplina apresenta uma bibliografia básica bem sucinta e traz como autor de referência Vygotsk. O seu programa a divide em três módulos: Módulo 1 - Perspectivas teóricas do desenvolvimento das pessoas com necessidades educacionais especiais; Módulo 2 - A unidade do desenvolvimento infantil: compreensão do desenvolvimento das pessoas com necessidades educacionais especiais; e Módulo 3 - Os processos de aprendizagem dos alunos com necessidades educacionais especiais. Essa disciplina é voltada basicamente para o processo de aprendizagem do estudante com deficiência. Não é destacado em nenhum momento da ementa da disciplina como ocorre essa aprendizagem em sala de aula e como docentes e pais devem se portar diante de dificuldades de aprendizagem e de aprendizagem em tempos diferentes, entre outros aspectos.

\subsubsection{Libras}

De acordo com a secretaria do curso de graduação em Pedagogia da UnB, a disciplina "Libras", encontrada no fluxo curricular, Anexo I, tem o nome de "Escolarização de Surdos e Libras". Ela tem como pré-requisito as disciplinas: "O Educando com Necessidades Educacionais Especiais" e "Aprendizagem e Desenvolvimento do PNEE”, cujo código é 100749.

Não consta a ementa da disciplina na secretaria do curso, sua bibliografia básica ou um programa para a realização de uma análise detalhada. Essa situação demonstra que a Faculdade de Educação não está preocupada com o que seus estudantes saibam, o que deverá ser estudado. Isso é reflexo de um Projeto Acadêmico de curso construído em 2002 que não apresenta as alterações solicitadas pelas Diretrizes Curriculares Nacionais para o curso de Pedagogia, demonstrando, assim, que está desatualizado quanto às questões referentes ao ensino de Libras. 


\section{CAPÍTULO IV - ADENTRANDO AS ESCOLAS: ANÁLISE E INTERPRETAÇÃO DA REALIDADE OBSERVADA}

\section{A ESCOLA DE CEILÂNDIA}

Nesta parte do trabalho, são analisados os dados obtidos por meio das observações, do questionário, da entrevista, do grupo focal e do Projeto Político Pedagógico PPP da escola de Ceilândia. As informações obtidas foram trianguladas e analisadas tendo como base a legislação referente ao assunto e a literatura específica.

O PPP foi analisado à luz das Orientações Pedagógicas: Projeto Político Pedagógico e coordenação pedagógica (2014) e livro instrucional da Secretaria da Educação do DF para a construção desses Projetos pelas escolas. Para a análise das observações, o questionário, a entrevista e o grupo focal foram levados em consideração a realidade em que a escola está inserida e o público ao qual atende.

\subsection{O Projeto Político Pedagógico da Escola}

O Projeto Político Pedagógico da escola de Ceilândia apresenta quase todos os elementos fundamentais elencados pela Orientação Pedagógica (2014). De acordo com essas orientações, o trabalho precisa de uma estrutura básica que deve conter: capa, sumário, apresentação do projeto e de seu processo de construção; historicidade da escola; diagnóstico da realidade escolar; função social; princípios orientadores das práticas pedagógicas; objetivos; concepções teóricas que fundamentam as práticas pedagógicas; organização do trabalho pedagógico da escola; concepções; práticas e estratégias de avaliação do processo de ensino e aprendizagem; organização curricular da escola; plano de ação para implementação do Projeto Político Pedagógico; acompanhamento e avaliação do PPP; projetos específicos individuais ou interdisciplinares da escola; e referências bibliográficas. O PPP da escola deixou de expor em sua estrutura uma apresentação do projeto, seu processo de construção e a organização do trabalho pedagógico.

A escola iniciou sua trajetória em 1980 com o atendimento de alunos do Ensino Fundamental e como apoio à formação inicial de professores das extintas Escolas de Aplicação e Normal (PPP ESCOLA CEILÂNDIA, 2014). Em 2004, foi iniciado o atendimento na Educação Infantil e no Ensino Fundamental até o $5^{\circ}$ ano. A escola situa-se no Setor Sul de Ceilândia, entre as quadras residenciais, próxima à Administração Regional de Ceilândia, à praça do trabalhador e ao Hospital Regional da cidade. Em 2014 a escola tinha 
676 alunos. Ela tem sala de recursos e classe de ensino especial, mas não fica claro o quantitativo de salas de classe especial na tabela apresentada pelo PPP.

Na capa é identificado que o Projeto foi construído em abril de 2014 pela equipe diretiva e pela equipe de coordenadores. Deixa implícito que alguns professores da Educação Infantil, do Ensino Fundamental, das Classes Especiais, Orientadores Educacionais, Equipe de Atendimento Especializado, Servidores, Pais/Responsáveis e a Comunidade escolar também participaram dessa elaboração. Não está expresso o quantitativo de integrantes de cada segmento que participou dessa construção nem como e em quais circunstâncias esse projeto foi elaborado. É importante que venha expresso no PPP como ocorreu essa construção, como foram elaboradas as reuniões, como foi o papel da comunidade nesse planejamento, porque, desse modo, demonstra de forma clara ao leitor que essa foi verdadeiramente uma construção coletiva e não uma imposição da equipe diretiva da escola.

O Projeto Político Pedagógico deve ser construído com o esforço coletivo, visando à construção de uma escola democrática. Esse princípio da gestão democrática está expresso no artigo 206, inciso VI, da Constituição Federal, e na Lei de Diretrizes e Bases, no artigo $3^{\circ}$, inciso VIII. Não são observadas na construção do PPP as Orientações Pedagógicas (2014) em que se coloca que, neste momento, devem ser descritos como ocorreu a elaboração do Projeto, os sujeitos que participaram da sua construção e uma breve descrição dos capítulos do PPP. Com a não identificação dos sujeitos que participaram da elaboração do Projeto, abre-se uma margem para questionamentos: até que ponto este PPP foi construído coletivamente? Verdadeiramente ocorreu uma participação dos pais/responsáveis, da comunidade escolar, dos servidores e dos professores nesta construção?

A missão da escola é exposta no PPP, mas esse ponto não está elencado na estrutura do Projeto Político Pedagógico recomendado pelas Orientações Pedagógicas (2014). Como missão, a escola deve "possibilitar a aprendizagem de todos e todas" (PPP Escola Ceilândia, 2014, p. 7), desenvolver serviços qualificados e preparar o aluno para desenvolver seu papel como cidadão. A missão da escola pode ser confundida, em alguns tópicos, com os princípios do Estado elencados no artigo 206 da Constituição Federal de 1988.

O Projeto Político Pedagógico da escola de Ceilândia apresentava em sua estrutura, no ano de 2014, 676 estudantes, distribuídos em dois turnos (matutino e vespertino). Contava com 34 alunos em situação de inclusão, além de possuir uma classe especial para alunos com deficiência auditiva, tendo 17 estudantes. É apresentado o quantitativo de professores e servidores da escola, discriminados por categorias, como: auxiliares de cozinha, secretária escolar, auxiliares de limpeza etc. Há uma questão intrigante, pois a escola possui 
Técnicos de Assuntos Educacionais - Monitores que não são apresentados no Projeto Pedagógico da escola. Em conversa com a direção, ela indicou ter em seu quadro dois Monitores.

O diagnóstico da realidade está limitado a uma tabela de gráficos e o entendimento deles é limitado a quem compreende as siglas utilizadas pela alfabetização, pois, da forma apresentada pela escola, não é utilizada uma legenda para as pessoas que não compreendem essa linguagem. As tabelas evidenciam a situação inicial do $1^{\circ}$ ao $3^{\circ}$ ano e existem alguns códigos como: PS1, PS2, S, A, A1, A2, A3 e A4. Esses códigos são referentes a PS1: Pré-silábico 1; PS2: Pré-silábico 2; S: Silábico; A: Alfabetizado; A1: Alfabetizado 1; A2: Alfabetizado 2; A3: Alfabetizado 3; e A4: Alfabetizado 4. O PPP da escola limita a compreensão desses dados apenas às pessoas que elaboraram o Projeto por não apresentarem a legenda na construção da tabela.

No diagnóstico da realidade, também é exposto o Índice de Desenvolvimento da Educação Básica - Ideb da escola, que apresentava, em 2009, a nota 5.3 e, em 2011; 5.7. A escola apresentou um desempenho menor que a meta projetada de 2011 que seria de 5.9. Mesmo assim, o índice alcançado pela escola é superior à meta exposta pela média dos estudantes do Brasil, que foi de 5.0. Também foram divulgados os resultados do Sistema de Avaliação da Educação Básica - Saeb de 2013 por meio da Avaliação Nacional de Alfabetização - ANA (SAEB 2013/ANA). Essa avaliação mostra que a escola tem $54,4 \%$ das crianças no nível inferior em relação ao assunto de textos de caráter científico e, em matemática, 31,25\% consegue reconhecer frequências iguais em gráficos de coluna. No projeto não existe nenhuma nota explicando ao leitor o que são essas siglas e provas, o que seria imprescindível, pois o conhecimento a respeito dessas provas restringe-se às instituições de ensino e aos órgãos governamentais que as aplica. Nas Orientações Pedagógicas (2014), é solicitada que sejam apresentadas as características social, econômica e cultural da comunidade. É observado que nenhuma dessas características foi levantada nesse diagnóstico, ficando limitada a apenas apresentar dados de testes padronizados elaborados pelo Ministério da Educação. Não existe nenhuma explicação ou comentário de como ocorreu a sua execução, a elaboração dessas provas e a construção desses dados.

O Projeto Político Pedagógico compreende que a função social da escola é a de "garantir a aprendizagem de conhecimentos, habilidades e valores necessários à socialização do indivíduo" (PPP ESCOLA CEILÂNDIA, 2014, p. 15), também deve formar cidadãos críticos, reflexivos e autônomos que estejam preparados para atuar na vida em sociedade. A construção da função social deve partir do coletivo de sujeitos que participaram da elaboração 
do PPP da escola. Sendo assim, cada colégio é responsável por construir a sua função social, que deverá ser amplamente divulgada à comunidade escolar, segundo as Orientações Pedagógicas (2014). De acordo com Veiga (2004, p. 24), “é necessário decidir coletivamente o que se quer reforçar dentro da escola e como detalhar as finalidades para atingir a almejada cidadania”. Essa construção coletiva da função social da escola e de suas finalidades deve buscar garantir que todos os sujeitos sejam ouvidos, para que haja uma concordância nas metas a serem alcançadas pela escola.

A escola apresenta, em seu Projeto Político Pedagógico, os princípios elencados na LDB 9394/96, tais como:

\begin{abstract}
Art. $3^{\circ} \mathrm{O}$ ensino será ministrado com base nos seguintes princípios: I igualdade de condições para o acesso e permanência na escola; II - liberdade de aprender, ensinar, pesquisar e divulgar a cultura, o pensamento, a arte e o saber; III - pluralismo de ideias e de concepções pedagógicas; IV - respeito à liberdade e apreço à tolerância; V - coexistência de instituições públicas e privadas de ensino; VI - gratuidade do ensino público em estabelecimentos oficiais; VII - valorização do profissional da educação escolar; VIII - gestão democrática do ensino público, na forma desta lei e da legislação dos sistemas de ensino; IX - garantia de padrão de qualidade; $\mathrm{X}$ - valorização da experiência extraescolar; XI - vinculação entre a educação escolar, o trabalho e as práticas sociais. XII - consideração com a diversidade étnicoracial. (LDB, 2015, p. 9-10).
\end{abstract}

A escola escolheu apenas alguns dos princípios da LDB como base do seu Projeto Pedagógico, com a justificativa de que eram os que mais se enquadravam em suas ações pedagógicas e com a sua função social. Foram eles:

a) igualdade de condições para o acesso e permanência na escola; b) liberdade de aprender, ensinar, pesquisar e divulgar a cultura, o pensamento, a arte e o saber; c) respeito à liberdade e apreço à dignidade humana; d) valorização do profissional da educação escolar; e) gestão democrática do ensino público, na forma desta lei e da legislação dos sistemas de ensino; f) princípios legais vinculam-se ao princípio: "TODOS E TODAS PODEM APRENDER” (PPP CEILÂNDIA, 2014, p. 17).

O último princípio não consta na legislação educacional nacional, nem na do Distrito Federal. Foi possível concluir que este seria um princípio criado pela escola para enfatizar que todos os seres humanos são capazes de aprender. Essa afirmação traz a suposição de que a escola está preocupada em que todos os alunos, mesmo os que tenham algum tipo de deficiência, transtorno global do desenvolvimento ou altas habilidades, possam desenvolver, em plenitude, todas as suas capacidades. 
Dentro dos princípios da escola, é apresentada uma pesquisa realizada pelo diretor. Este tópico não seria para a apresentação de uma pesquisa acerca do clima organizacional, pois não contribui para enfatizar os princípios que orientam a prática pedagógica do grupo de professores e servidores da comunidade.

O PPP apresenta como objetivo geral a orientação de seus estudantes a uma cidadania plena com o objetivo de intervir em seu contexto social. Como objetivos específicos, tem-se: a implementação de projetos de letramento, conhecimentos matemáticos, sala de leitura; a implantação da biblioteca e reforma do parquinho; a consolidação de projetos de educação ambiental e diversidade cultural, a otimização da informática educativa, e a disponibilização da inclusão dos estudantes com deficiência "por meio do atendimento nas salas regulares, nas salas de recursos e na participação em todos os espaços/tempos/ações da escola" (PPP ESCOLA CEILÂNDIA, 2014, p. 21). Elencar esses objetivos como metas as serem alcançadas pelo PPP é o primeiro passo para que elas comecem a ser executadas. Por meio das observações foi possível ver que estava sendo realizada uma reforma na quadra de esportes, onde era colocada uma grama sintética. Também foi possível visualizar que a sala de informática estava em um bom estado e com todos os computadores funcionando para os estudantes poderem utilizar.

Em relação aos alunos com deficiência e à sua inclusão, primeiramente, eles são chamados de ANEE pela instituição, que seria a sigla de Alunos com Necessidade Educacionais Especiais. Essa sigla, apesar de ainda ser utilizada pela Secretaria de Educação, demonstra que a escola ainda não está adequada à nova nomenclatura de pessoa com deficiência. É importante esse objetivo para os alunos com deficiência, pois busca promover uma efetiva participação deles na vida escolar. Os objetivos apresentados pelo PPP estão de acordo com as Orientações Pedagógicas (2014), porque eles devem possibilitar que a escola alcance os resultados determinados para um período e a concretização de sua função social. Desse modo, concordando com Veiga (2008, p. 23), "as finalidades da escola referem-se aos efeitos intencionalmente pretendidos e almejados". Desejar a participação dos estudantes com deficiência em todos as esferas da escola demonstra a intencionalidade da escola em alcançar essa meta.

De acordo com o PPP, a escola de Ceilândia está organizada em ciclos do $1^{\circ}$ ao $3^{\circ}$ ano e em séries do $4^{\circ}$ e $5^{\circ}$ ano. É informado que existe um planejamento da rotina diária, com atividades permanentes e por meio de uma sequência didática. A relação com os pais e a comunidade ocorre por meio da agenda escolar, das reuniões de pais e das festividades. A organização do trabalho da escola é apresentada de maneira superficial ao leitor, ela não 
detalha os tipos de atividades que são desenvolvidas nas atividades permanentes nem qual seria essa sequência didática.

O tópico acerca de concepções teóricas, práticas e avaliação trata somente da avaliação escolar. É falado muito a respeito da avaliação como instrumento de repreensão e de ameaça aos alunos. Também é ressaltado que ainda hoje a avaliação representa um grande desafio para professores, orientadores e pais. A escola teve como tema de estudo a avaliação formativa, por meio da construção de um perfil de professor reflexivo e da utilização de instrumentos como "o diário de bordo, observação diária em sala de aula, teste da psicogênese, portfólio, atividades individuais e em grupo, relatório descritivo do aluno, prova, autoavaliação e reflexão sobre prática pedagógica" (PPP ESCOLA CEILÂNDIA, p. 25). A avaliação formativa é entendida por Villas Boas (2008, p. 39) como a que "engloba todas as atividades desenvolvidas pelos professores e seus alunos, com o intuito de fornecer informações a serem usadas como feedback para reorganizar o trabalho pedagógico". É entendido que apenas o estudo não é suficiente para a modificação da avaliação. O estudo deve vir acompanhado de perto da prática, da análise e da avaliação dessa aplicação, principalmente com a ajuda de coordenadores e diretores escolares. É solicitado nas Orientações Pedagógicas (2014) que exista uma breve descrição da utilização dos instrumentos avaliativos, o que não foi observado neste Projeto Pedagógico.

Para Veiga (2008, p. 31), o processo de avaliação do Projeto Político Pedagógico "envolve três momentos: a descrição da realidade e a problematização da realidade escolar; a compreensão crítica da realidade descrita e problematizada; e a proposição de alternativas de ação, momento de criação coletiva”. Em nenhum momento é apresentada no PPP da escola de Ceilândia uma verdadeira problematização da situação da escola nem são mostradas possíveis alternativas para a solução desses problemas. Também é gerada uma dúvida acerca da construção coletiva deste projeto, o que abre espaço para o entendimento de que pode ter sido uma construção unilateral, não visando ao coletivo. Essa falta de informação abre espaço para que não haja um processo de avaliação deste Projeto.

Em relação à organização curricular da escola, ela está construída de acordo com o documento circular da SEDF. Ela informa que Língua Portuguesa, Matemática, Artes, História e Geografia serão integradas pelos eixos ludicidade, alfabetização e letramento e, nos eixos transversais, educação para a diversidade, cidadania, educação em e para os Direitos Humanos, e educação para a sustentabilidade. De acordo com as Orientações Pedagógicas (2014), neste espaço deveria vir expresso como ocorrerá a interdisciplinaridade, como seriam trabalhados os projetos, a relação teoria e prática e como ocorreriam o trabalho com os eixos 
transversais. De forma sucinta, não foi apresentado pelo PPP nenhum desses aspectos, deixando uma grande abertura para diversas possibilidades de trabalho ou até mesmo nenhuma.

No plano de ação da escola, não são desenvolvidas as atividades propostas pela Orientação Pedagógica (2014). É apresentado apenas um cronograma das atividades a serem realizadas durante o ano. Não são detalhadas, conforme as orientações, em: gestão pedagógica, gestão de resultados educacionais, gestão participativa, gestão de pessoas, gestão financeira e gestão administrativa. A não separação em atividades e um cronograma tão resumido, prejudica significativamente a forma de trabalho e a credibilidade do PPP.

De acordo com o PPP, a sua avaliação será realizada bimestralmente e em datas estipuladas pela Secretaria de Educação quando todos serão convocados para a discussão do trabalho que está sendo realizado com o Projeto.

De maneira geral, o PPP da Escola de Ceilândia apresenta muitas fragilidades que prejudicam a sua execução por todos os membros da escola. Iniciando pela não apresentação dos membros que elaboraram o Projeto, fica a dúvida se ele realmente foi produzido pelo coletivo ou se ficou restrito aos membros diretivos da escola. Essa construção coletiva é importante, pois demonstra que houve uma ação intencional e teve um sentido explícito em sua elaboração, afirmando, assim, um compromisso coletivo (VEIGA, 2008). Outro ponto que abre espaço para essas dúvidas é a não apresentação de como este Projeto foi construído, partindo do princípio de que deveriam existir reuniões para os debates. Ainda segundo Veiga (idem, p. 23),

a construção do projeto político pedagógico é um instrumento de luta, é uma forma de contrapor-se à fragmentação do trabalho pedagógico e sua rotinização, à dependência e aos efeitos negativos do poder autoritário e centralizador dos órgãos da administração central.

Desse modo, ao não garantir que seja realizada uma construção coletiva de seu PPP, a escola de Ceilândia perde sua autonomia contra os poderes autoritários e pode mascarar situações problemáticas que poderiam ser resolvidas por intermédio do coletivo.

São expostos de forma bem precária a realidade da escola e o diagnóstico dos estudantes que a frequentam. Não é possível saber se são de classe média alta, média, baixa; de onde são oriundos e qual o grau de escolarização de seus pais, entre tantos outros aspectos que ficam vagos. Concordando com Veiga (2008, p. 26) é necessário, 
ao analisar a estrutura organizacional, ao avaliar os pressupostos teóricos, ao situar os obstáculos e vislumbrar as possibilidades, os educadores vão desvelando a realidade escolar, estabelecendo relações, definindo finalidades comuns e configurando novas formas de organizar as estruturas administrativas e pedagógicas para a melhoria do trabalho de toda a escola na direção que se pretende.

A ausência da concepção teórica que fundamenta o PPP da escola e os rumos que devem ser seguidos prejudicam de forma significativa o entendimento de quais pressupostos estão sendo seguidos para a tomada de decisões e até mesmo o trabalho em sala de aula com os estudantes. Assim, deixando vagas essas concepções, pode ocorrer uma fragmentação do trabalho pedagógico. A falta da apresentação do currículo e de sua estruturação na interdisciplinaridade e nos eixos transversais abre precedentes para que não sejam executadas, contrariando, assim, os objetivos elencados no próprio Projeto Político Pedagógico. De acordo com Veiga (2008, p. 23), existem pelo menos sete elementos básicos que são apontados como fundamentais na construção de um Projeto Político Pedagógico: “a) as finalidades da escola; b) a estrutura organizacional; c) o currículo; d) o tempo escolar; e) o processo de decisão; f) as relações de trabalho; g) a avaliação". A ausência de um ou mais desses elementos prejudica de forma significativa a autonomia da construção deste PPP e de sua legitimidade diante da comunidade escolar.

Também não são apresentadas estratégias para a inclusão de estudantes com deficiência. A falta de especificação para a inclusão dificulta o trabalho de professores e servidores que atuam com esses estudantes, principalmente, quando ele não é construído pelo coletivo da escola, servidores, pais e comunidade. Assim, o senso de responsabilidade pelo todo torna-se mais fraco e abre lacunas para que a inclusão não seja de fato implementada.

\subsection{Professor Carlos: formação e posicionamentos}

O professor Carlos primeiramente realizou o Curso Normal. Com essa formação, ingressou como professor concursado de anos iniciais na Secretaria de Educação do Distrito Federal em 1997. Com a mudança da legislação relativa à formação de professores, foi necessário que realizasse o curso de Pedagogia para continuar atuando nos anos iniciais do Ensino Fundamental.

Ele graduou-se em Pedagogia pela Universidade de Brasília. O curso feito pelo professor é oriundo de uma parceria da UnB com a Secretaria de Educação do DF. Os ingressos a esse curso foram de professores da rede que possuíam o Magistério, mas ainda não tinham curso superior. Essa parceria surgiu para atender a necessidade de formação de 
professores em nível superior, indispensável pela nova Lei de Diretrizes e Bases. De acordo com a Lei, todos que atuassem nos anos iniciais deveriam possuir curso superior ao final da década da educação 1997 a 2007.Conforme o Art. 87. § 4º "Até o fim da Década da Educação somente serão admitidos professores habilitados em nível superior ou formados por treinamento em serviço" (BRASIL, 2016, p. 37). O professor Carlos concluiu sua graduação no curso de Pedagogia da UnB em 2003.

Em seu curso, havia apenas uma disciplina acerca de Educação Especial, a chamada "Fundamentos da Educação Especial". Única em sua matriz curricular que abordava o tema da Educação Especial e Inclusiva e estava planejada para o terceiro semestre do curso. O professor relatou que foi uma matéria muito rica, pois conseguiu aliar a teoria à prática, por meio das idas a campo, no Centro de Ensino Especial de Brazlândia.

Começou a aplicar o que aprendia na disciplina Fundamentos da Educação Especial na sala de aula onde atuava e, ao final, apresentava aos professores do curso da UnB relatórios a respeito do observado e aplicado. De acordo com Ferreira e Ferreira (2013, p. 37), é na formação inicial que o futuro docente deve ter contato com "um eixo capacitador para a educação na perspectiva da diversidade". Essa relação com a diversidade deve ser vivenciada em todos os momentos do curso, porque contribui para futuras práticas de não exclusão do diferente e uma maior equidade entre todos.

O curso de Pedagogia para professores em Início de Escolarização tinha por objetivo principal a "capacitação em exercício, a articulação da teoria e prática se dará no próprio espaço de trabalho do cursista" (UNB, 2000, p. 3). O docente Carlos enfatiza que " $O$ curso que fiz foi diferenciado, porque tínhamos a teoria aliada à prática, pois eu aplicava em sala de aula o que aprendia nos livros" (Professor Carlos, 2015). Por intermédio dessa ligação da teoria com a prática e por estar em sala de aula ele, conseguia visualizar as situações apresentadas nas disciplinas e colocá-las em prática.

Depois o professor Carlos realizou um curso de especialização em Psicopedagogia e relata que teve um novo contato com a Educação Especial. Ele é enfático em falar que a Secretaria de Educação do DF oferece cursos de aperfeiçoamento em todos os semestres pela EAPE.

Existe formação sim. Por mais que falem que não há, ela existe. Alguns professores vão para esses cursos pelo diploma, para pular barreira e escolher uma turma melhor, não conseguindo perceber a relação entre a teoria apresentada nos cursos e a prática de sala de aula (Professor Carlos, 2015). 
Essa realidade apresentada pelo professor mostra-se verdadeira, porque uma grande parcela dos professores só procura esses cursos para obtenção do diploma para progressão funcional e para a escolha de turmas. Eles esquecem que o objetivo principal do curso é aprender novas teorias para a realização de mudanças em suas práticas diárias de sala de aula.

\section{A Inclusão}

O professor Carlos entende que a Inclusão é o ato de incluir aqueles que historicamente foram excluídos. Ele compreende que a inclusão vai além de pessoas com deficiência, ela é para todos aqueles que, por algum motivo, estão excluídos da sociedade. Esse docente acredita que muitos professores têm medo do trabalho com a inclusão e ele, por ser sensível às temáticas étnico-raciais, tem facilidade em trabalhar com a diversidade. " $E u$ sou muito sensível às temáticas de diversidade, de direito ao próximo, das questões étnicoraciais. Por isso, eu tento fugir das turmas em inclusão, não por não gostar, mas pela minha sensibilidade, mas sempre acabo ficando com essas turmas" (Professor Carlos, 2015). Góes (2013, p. 80) acredita que "naturalmente, há educadores sensíveis e responsivos à demanda para incentivar a compreensão da pluralidade cultural, o que sinaliza a possibilidade de a escola ficar mais alerta aos problemas coletivos". Essa sensibilidade natural do professor Carlos exemplifica, de forma clara, essa colocação da autora, destacando que esse maior interesse gera diversas possibilidades de ação na escola acerca dos temas relativos à diversidade e à inclusão.

Carlos percebe que existe um grande desgaste no trabalho com as questões inclusivas: "Quando estou com turmas que são inclusivas me desgasto muito por querer fazer a diferença, por querer transformar" (Professor Carlos, 2015). Por querer fazer a diferença, isso exige bastante esforço do professor na sensibilização de todos que cercam essas pessoas, inclusive a escola como um todo; por querer fazer um trabalho diferente e por sempre elevar a autoestima de todos que estão vinculados ao processo inclusivo por serem sempre subjugados pela sociedade. Crochík (2012, p. 43) acredita que "é a cultura, na dependência das necessidades e dos conflitos sociais, que se possibilita a formação para a segregação ou para a inclusão". Então, esse posicionamento do autor corrobora para o entendimento da preocupação do professor Carlos, em eliminar qualquer forma de preconceito em sua sala de aula e sempre procurar elevar a autoestima, principalmente dos estudantes segregados, pois essa atitude influencia diretamente na formação de atitudes inclusivas desses estudantes. 
O professor já trabalhou com estudantes com deficiência intelectual, deficiência física e, no ano de 2015, com estudantes autistas e com altas habilidades. "Eu já trabalhei em outras escolas com inclusão. Já tive dois alunos com deficiência intelectual, ano passado trabalhei com duas irmãs gêmeas que tinham deficiência física e esse ano estou com o Autismo e Altas Habilidades" (Professor Carlos, 2015). A diversidade de alunos com quem o professor Carlos trabalhou ao longo de seu percurso como professor corrobora para a ideia de que ele está sempre em contato com situações de inclusão. Esse contato favorece significativamente para o seu interesse e a busca por formação continuada visando à educação inclusiva e à diversidade.

\section{Desafios}

Segundo o professor Carlos, o preconceito é um dos maiores desafios a serem enfrentados. "A maior dificuldade que percebo é a questão do preconceito. Infelizmente há crianças preconceituosas" (Professor Carlos, 2015). Por intermédio desse relato, o docente afirma a existência de discriminação entre as próprias crianças e que ele tem um trabalho diário de enfrentamento contra essa atitude, principalmente na hora do intervalo com os estudantes de outras turmas. "Eu gosto de ficar vigiando. Minha pesquisa são as crianças. Eu fico observando como tratam as crianças umas às outras e infelizmente percebo que o preconceito está presente" (Professor Carlos, 2016). Essa atitude de observação demonstra a importância que o professor Carlos dá ao entendimento das relações que ocorrem no exterior da sala de aula as quais influenciam de maneira direta as relações internas desse espaço. Para Góes (2013, p. 75), “os alunos precisam tornar-se sensíveis (mais que tolerantes) às diferenças entre comunidades, etnias, bem como às diferenças dos que apresentam necessidades educacionais especiais", eles também precisam aprender a respeitar e assimilar atitudes solidárias. Apenas por meio dessas mudanças de atitudes poderá ocorrer uma mudança de pensamento e comportamento.

Outro desafio está relacionado à adaptação da escola aos estudantes com deficiência: adequações físicas e atitudinais. As físicas dizem respeito à construção de rampas de acesso, banheiros adaptados e piso tátil em toda a escola. O professor Carlos expõe que existiu a construção de rampas na escola, mas elas foram destruídas pelos próprios estudantes que não compreenderam a existência de alunos que precisavam daquele suporte para se locomoverem pela escola.

As adequações atitudinais são mais difíceis de ser executadas, pois exige uma mudança de postura de cada pessoa que faz parte da escola. O professor relatou que muitos 
questionamentos já foram realizados por ele à direção da escola acerca da questão do respeito às diferenças, porém a instituição não conseguiu compreender que a inclusão não é apenas dentro da sala de aula. As atitudes devem ser tomadas por todos na escola, desde os professores e a direção a alunos, servidores e pais. O professor expõe que

A escola também tem que estar adequada à inclusão, não apenas o professor da turma. Lembro que uma vez questionei aqui na escola em que trabalhamos com turmas inclusivas, mas não trabalhamos a questão do respeito. Falaram que eu estava sendo muito irônico. Então, se os professores e os servidores não estão preparados, infelizmente a escola não funciona apenas com uma turma de inclusão (Professor Carlos, 2015).

Para Góes (2013), a escola não deve tomar a presença do aluno com deficiência como acessória, "sem afetar o projeto da escola, o que se reflete na realização de pequenos ajustes ao aprendiz e na distribuição dessa responsabilidade quase que exclusivamente ao professor" (idem, p. 65). Essa atitude descrita reflete que a escola de Ceilândia ainda não percebeu a importância de conter ações em seu Projeto Político Pedagógico que estimulem uma mudança de postura por parte da direção e de todos os outros atores envolvidos nos processos educativos. Essa transferência de responsabilidade para o professor é evidente e prejudica o trabalho do docente em sala de aula, pois mostra aos estudantes duas realidades distintas, uma dentro da sala de aula e outra nos ambientes sociais da escola.

O professor Carlos relata, em diversos momentos, a sua dificuldade de diálogo com a direção da escola e o pessoal da sala de recursos.

Eu sou uma pessoa muito isolada e crítica com relação à educação. Eu percebo que há uma quebra entre coordenação, direção e sala de aula. Eu gostaria que a coordenação da escola estivesse mais presente em sala, mais próxima dos professores, mas infelizmente em todas as escolas que trabalhei sempre houve essa quebra (Professor Carlos, 2015).

O professor muitas vezes realiza um trabalho isolado, por não ter apoio e incentivo da coordenação da escola e dos responsáveis pelas salas de recursos. Ele recebeu ajuda na construção da adequação curricular, mas apenas isto, pois nunca teve apoio em sala de aula para o desenvolvimento de atividades diferenciadas ou práticas inclusivas. Concordando com Fleuri (2009), “a formação, a preparação e a conscientização dos profissionais são fundamentais para ajudar o professor e a professora a enfrentarem o próprio medo, a própria insegurança e a desestabilização que a presença do novo instaura". Essa falta de preparo da direção e da coordenação é evidente na escola de Ceilândia, pois, a partir do 
momento que eles não estão sensibilizados com as questões que a inclusão requer, isso demonstra a total falta de preparo e formação desses profissionais no auxílio do professor que trabalha com turmas inclusivas.

De acordo com Ferreira e Ferreira (2013, p. 38), a adequação curricular, assim como todas as outras atividades a serem desenvolvidas com os estudantes com deficiência, deve buscar "o máximo desenvolvimento de cada aluno, dentro da meta geral colocada". Essa busca não exclui a necessidade dos estudantes em aprenderem os conteúdos referentes a cada ano escolar, mas enfatiza a necessidade de mostrar a eles atitudes básicas de cidadania, respeito ao próximo, localização espacial, entre outros aspectos.

A sala de recursos de altas habilidades e superdotação foi construída na escola, por haver uma grande quantidade de espaços ociosos na escola. "Essa escola aqui é diferenciada porque havia e ainda tem alguns espaços ociosos" (Professor Carlos, 2015). Concordando com Fleith (2009), é por meio das condições ambientais apresentadas a criança com altas habilidade e/ou superdotação que o seu desenvolvimento pode progredir ou ser inibido. De acordo com a Nota Técnica ${ }^{\circ} 15$, de 2015,

a universalização do atendimento escolar aos estudantes com deficiência, transtornos globais do desenvolvimento e altas habilidades/superdotação, na faixa etária de 4 a 17 anos, na rede regular de ensino, atende o compromisso assumido pelo Brasil, ao ratificar a Convenção sobre os Direitos das Pessoas com Deficiência (BRASIL, 2015, p. 45).

Sendo assim, a construção da sala de recursos específica para altas habilidades na escola de Ceilândia colabora para a consolidação do compromisso do Brasil em tornar a educação cada vez mais inclusiva.

A presença da sala de altas habilidades na escola influencia, de maneira significativa, o desenvolvimento dos estudantes que a frequentam, pois eles encontram nesse ambiente um lugar propício para desenvolver habilidades que não puderam ser trabalhadas em sala de aula. A estudante com altas habilidades é atendida nesta sala uma vez por semana no turno contrário de aula. Vale ressaltar que a troca entre esses professores é bem pouca, tendo ocorrido quando a aluna faria uma prova.

Existe uma sala específica para a aluna. Ela vem à escola uma vez por semana em turno contrário para trabalhar as habilidades. O único momento em que houve uma troca com o professor da sala de recursos foi quando a estudante realizou a Olimpíada Brasileira de Astronomia - OBA, apenas neste momento houve uma troca (Professor Carlos, 2015). 
Para Góes (2013), essa falta de diálogo entre os professores faz que as ações fiquem parcial ou totalmente desvinculadas. Isso prejudica a aprendizagem do estudante acompanhado por esse espaço que deveria estar integrado à sua aprendizagem de sala de aula. De acordo com a Nota Técnica nº46, de 2013 (BRASIL, 2015, p. 91), para os estudantes com altas habilidades ou superdotação deve ser desenvolvido um "conjunto de atividades, visando atender as especificidades educacionais de tais estudantes, por meio do enriquecimento curricular, de modo a promover a maximização do desenvolvimento de suas potencialidades e habilidades". A desarticulação entre a sala de recursos e a sala de aula regular contraria o indicado na Nota Técnica nº55 de 2013 (BRASIL, 2015), onde é explicado que o atendimento deve ser realizado juntamente com o professor do ensino regular. Essas atividades deveriam ser realizadas em parcerias com a sala de aula que o estudante frequenta, pois desse modo haveria uma articulação entre esses espaços e, assim, o estudante não veria conteúdos e atividades de forma fragmentada.

A sala de recursos para o aluno com síndrome de Asperger foi dispensada, porque o aluno consegue desenvolver todas as habilidades necessárias para a turma em que está matriculado sem esse auxílio e ele tem dificuldade em acordar cedo para frequentar as aulas em turno contrário por tomar medicação que causa sonolência.

O Conrado estava sendo atendido pela sala de recursos, mas achamos melhor não dar continuidade, porque o aluno tem dificuldade em acordar cedo, pois toma remédio que causa sonolência. Então conversamos na sala de recursos e como ele está acompanhando a turma e aprende com facilidade os conteúdos, para ele esse atendimento foi dispensado (Professor Carlos, 2015).

O aluno sem diagnóstico é atendido pela Pedagoga para desenvolver com profundidade habilidades de desenho, "com o Caio existe, sim, e a Pedagoga sempre vem comentar como está o desenvolvimento dele" (Professor Carlos, 2015).

Foi sábia a identificação do professor Carlos em não prosseguir com a sala de recursos com o aluno com Asperger. Isso demonstra que ele tem consciência do aprendizado de seus alunos em sala de aula. Kassar (2013) mostra que muitas vezes estudantes são encaminhados aos serviços especializados sem necessidade específica e esses espaço tentam resolver todas as dificuldades dos alunos. Concordando com as autoras, em muitos casos, o problema não é de aprendizagem, mas, sim, de "ensinagem" e as escolas tendem a camuflar essa falha encaminhando os alunos a salas de recursos e serviços especializados. Esse não seria o caso do aluno sem diagnóstico do professor, pois o aluno frequenta a sala de recursos 
para desenvolver habilidades que não seriam possíveis suas ampliações em uma sala de aula convencional.

O apoio da família e a sua presença são imprescindíveis para o desenvolvimento de toda e qualquer criança no ambiente escolar. Essa presença é bem mais importante quando diz respeito a crianças com deficiência, pois o apoio da família é fundamental e reflete no trabalho do professor em sala de aula. O docente Carlos relata que possui um apoio significativo das famílias de todos os alunos de sua turma. Quando perguntado especificamente a respeito do aluno autista e da estudante com altas habilidades, o professor respondeu que as famílias são bem presentes, estão sempre preocupadas com o desenvolvimento de seus filhos em sala de aula e procuram sempre alternativas para o melhor desenvolvimento deles.

O docente Carlos informa que possui apenas dificuldade com a família do aluno cuja família não aceita o diagnóstico de autismo. Ele expõe que a mãe do aluno não vai mais à escola após ter sido convocada para uma reunião com a equipe de apoio especializado, quando foi descrita a situação do aluno e solicitado um encaminhamento ao médico para comprovação do diagnóstico avaliado pela equipe escolar.

A mãe da Célia está sempre conversando comigo e a mãe do Conrado também, mas a do Caio tem resistência à escola, após uma avaliação realizada pelo aluno para diagnóstico do transtorno global do desenvolvimento. Ultimamente sempre tem vindo o pai dele saber do seu desempenho, mas sempre rapidamente e sem perguntar muitos detalhes (Professor Carlos, 2015).

O aluno com síndrome de Asperger não necessita do apoio de um monitor, porque o estudante é totalmente independente em suas atividades de sala de aula e em sua higiene pessoal. O professor Carlos relata que já trabalhou com alguns monitores e que eles sempre ajudavam bastante na locomoção dos estudantes e em suas atividades diárias.

O estudante Conrado, que tem síndrome de Asperger, apresenta um desenvolvimento semelhante ao dos demais estudantes da classe. É um aluno bem participativo e sempre que questionado responde as perguntas feitas pelo professor Carlos. Algumas vezes erra igual os demais alunos, mas também acerta as questões. Pelo relatado na entrevista e o observado em sala de aula, o aluno consegue ter um desempenho satisfatório em sala de aula e aprende da mesma forma que os demais estudantes.

A aluna Célia tem uma aprendizagem excepcional. É a estudante mais nova da turma, com apenas nove anos. Em sala de aula, o professor Carlos, além de explicar a matéria 
usual, também a estimula a aprender com um pouco mais de profundidade os conteúdos do seu quinto ano. Um dos exemplos que o docente Carlos apresenta de aprendizagem da aula é o tipo de texto que ela produz. Enquanto os demais estudantes produzem textos narrativos, a estudante elabora textos dissertativos. Conforme explica Carlos, a aprendizagem deste tipo de texto partiu da iniciativa da aula e ele complementa falando que ela produz excelentes textos e bem extensos para a idade dela.

\section{Práticas Inclusivas}

As práticas inclusivas na sala de aula do professor Carlos ocorrem de modo a deixar todos os alunos envolvidos nas atividades. O professor apresenta domínio total da turma, o que gera um clima de respeito em sala de aula. Essa é a primeira e mais importante prática a se fazer para que todos os estudantes caminhem juntos. Na execução de cada atividade em sala, lanche e atividades esportivas na quadra, os alunos só começam uma nova ação quando todos terminam as tarefas. Os que encerram antes são instruídos a pegarem livros nas caixas dispostas em cima de armários e realizarem leituras. Todos os estudantes respeitam essa atividade.

Outras práticas bastante utilizadas pelo docente são o trabalho da autoestima dos estudantes, a construção de valores e o respeito pela diversidade: "eu trabalhei com duas crianças que eram subjugadas pela escola e sempre realizava com elas o trabalho de levantar a autoestima. Eu gosto muito de fazer isso, pois eu percebo que há mudança" (Professor Carlos, 2015). Para Fleuri (2009), é papel do professor realizar um trabalho no qual o estudante identifique as suas diferenças de aprendizagem, pois não basta apenas inserir o estudante em classe sem que o professor saiba como trabalhar com ele, porque primeiramente o docente deve acreditar no potencial do aluno e no seu aprendizado. Esse trabalho de autoestima é fundamental para o desenvolvimento dos discentes em situação de inclusão, porque, em muitos momentos, eles se sentem subjugados pela escola e por seus colegas e esse trabalho do professor potencializa a sua autoestima, ajudando-o em seu aprendizado e sua capacidade de realização pessoal.

Em seu dia a dia, o professor Carlos também faz uso do "Pensamento do dia". Sempre no começo da aula, ele escreve no quadro alguma frase de cunho moral e que favoreça a autoestima e, a partir dela, ele aproveita para discutir com os estudantes o assunto, levanta questionamentos a respeito de preconceito, racismo, discriminação, intolerância e a necessidade de inclusão em todos os espaços. Essa prática colabora para a construção de atitudes positivas nos estudantes, alertando-os para possíveis situações de preconceito, 
exclusão, para construírem um pensamento crítico acerca do mundo que as cerca e do país em que vivem.

Em uma turma analisada, foi observado que os estudantes se respeitam mutuamente. Não foi presenciada, nos dias de observação, nenhuma situação de preconceito, discriminação ou indiferença porque os estudantes tratam todos como iguais. Nas brincadeiras de quadra e no recreio, a maioria gosta das brincadeiras coletivas, inclusive o aluno com síndrome de Asperger participa delas. Apenas o aluno que a família não aceita o diagnóstico de autismo tem dificuldade nas brincadeiras com a turma, ficando isolado, geralmente em um canto da quadra, brincando sozinho. Algumas crianças, quando percebem esse isolamento do aluno, procuram se unir a ele para realizarem alguma atividade juntos. O professor tenta que ele participe um pouco das práticas coletivas e apresenta as atividades de forma diversificada, mas, como o isolamento é uma das características dos transtornos globais do desenvolvimento, o docente não obtém sucesso na execução dos exercícios com o aluno, que prefere ficar longe do restante da turma realizando a própria brincadeira.

\subsection{A voz dos estudantes}

Os estudantes que participaram do grupo focal na escola de Ceilândia são da turma do professor Carlos e estão na faixa etária de nove e dez anos de idade. A classe possui um total de 15 estudantes, sendo que um apresentava síndrome de Asperger e um tem altas habilidades. Neste grupo ainda existia uma criança com traços de autismo, porém ainda sem diagnóstico, pois a família não aceitava o posicionamento da escola e do professor e se recusava levar a criança ao consultório de um médico especialista.

A realização do grupo focal contou com a participação de 13 crianças, porque duas crianças não estavam presentes no dia em que foi desenvolvido. Todas estavam devidamente autorizadas pelos seus pais e/ou responsáveis e estavam bastante empolgadas por estarem contribuindo para a construção da pesquisa.

Após iniciado o bate-papo com os estudantes a respeito da Inclusão, muitos mostraram que não compreendiam o significado da palavra e questionaram o que seria: “ $O$ que todo mundo aqui está se perguntando é o que é inclusão?" (Carolina, 2015). Foi apresentada a eles uma história da Turma da Mônica (Anexo V) que deixou claro o que era a Inclusão. Questionados novamente acerca do que entendiam do assunto, explanaram que todos possuíam os mesmos direitos e que a inclusão ajudava na construção da sociedade: “ $E u$ entendi que inclusão é uma coisa que ensina pessoas com deficiência a ajudar na sociedade" 
(Caio, 2015); "Eu entendi que inclusão é quando as pessoas com deficiência têm o mesmo direito que nós temos" (Cecília, 2015);

Eu entendi que a inclusão é quando as pessoas com deficiência têm o mesmo direito de todos. Tem gente que fala que não, que eles não servem para nada, tem até mesmo quem não goste deles e acabam judiando, mas eles têm os mesmos direitos que nós, eles são iguais (Cristina, 2015).

A fala dos estudantes demonstra que eles compreenderam o real significado da palavra inclusão, que são os direitos iguais, a igualdade de oportunidade em todos os ambientes e, principalmente, o respeito às diferenças.

Ficou evidente que os estudantes tinham muito mais conhecimentos de situações de exclusão do que de inclusão, pois foram contabilizados oito casos de exclusão ao longo de todo o grupo focal. Algumas das situações são de segregação por raça “Algumas vezes eu vejo que uns meninos morenos vão brincar e chega umas crianças brancas falando que são melhores do que eles" (Conrado, 2015). Essa explanação do estudante Conrado deixa evidente que ele tem receio de utilizar a nomenclatura negro, que seria a mais adequada, para retratar racialmente as pessoas. Isso evidencia que, mesmo a criança retratando que há essa discriminação, ela ainda continua a ter dificuldade em utilizar a palavra negro, apesar de o professor relatar que trabalha constantemente a questão racial em sala de aula.

Os estudantes também relataram a falta de acessibilidade em locais públicos: "Teve um dia que eu estava na rodoviária e lá não tinha elevador para as pessoas com deficiência. Deste modo, elas tinham que descer pelas escadas e, para isso, precisavam da ajuda de outras pessoas e nem sempre tinham pessoas dispostas a ajudar" (Carlota, 2015); "Um dia meu tio ajudou uma pessoa de cadeira de rodas. Ele e meu padrinho subiram com a pessoa pelas escadas" (Cristina, 2015). Essas falas dos alunos evidenciam a necessidade de acessibilidade às pessoas que têm deficiência; eles relataram que, pela falta de um elevador, essas pessoas estavam necessitando da ajuda de outras para realizar as suas atividades diárias. Essa inexistência de acessibilidade mostra a falta de preparo dos estabelecimentos em providências formas para que seus usuários sejam incluídos.

A aluna com altas habilidades relata um caso de eliminação em concurso público por motivo de deficiência.

A minha mãe disse que foi fazer uma prova para poder entrar para o trabalho. Ela tem deficiência na perna. Ela contou que, a cada dez pessoas que são chamadas sem deficiência, uma com deficiência deve ser chamada. Ela tirou o primeiro lugar e não a chamaram. Com isso, ela passou mais 
dois anos estudando e conseguiu tirar novamente o primeiro lugar e desta vez a chamaram (Célia, 2015).

A riqueza de detalhes apresentados pela estudante de nove anos é surpreendente, pois ela demonstra consciência dos fatos que estão sendo relatados. Quando ela retrata que devem ser chamadas, para cada dez pessoas sem deficiência uma com, ela demonstra conhecimento de proporções, habilidade esta que vai além do quinto ano. A estudante Célia foi adiantada uma série pelo seu desempenho em relação aos demais alunos em diversas habilidades. Essa aceleração não prejudicou o seu desempenho em sala de aula, e sim permitiu que ela desenvolvesse outras aptidões além das aprendidas no quinto ano pelos seus colegas, como a realizar dissertações, ao invés de apenas textos narrativos. De acordo com Fleith (2009), a aceleração não prejudica os alunos com altas habilidades, desde que executadas com cuidado e após uma avaliação criteriosa da criança, assim como o nível de receptividade do professor e da turma que acolherá a criança. No caso de Célia, a aceleração foi positiva, pois proporcionou a ela progredir na sua aprendizagem.

Também foram relatadas situações de exclusão pelos próprios estudantes em relação às crianças com deficiência em brincadeiras como queimada e futebol: "Na queimada, tem umas pessoas que não gostam e não escolhiam o Conrado porque achavam que ele era ruim, mas na verdade ele é muito bom na queimada" (Cristiana, 2015). Foram relatadas também chacotas e brincadeiras de mau gosto com os estudantes com deficiência: "Tem gente que trata o Caio diferente, só porque ele brinca que é um animal. Tem pessoas que ficam falando mal e não gostam de chegar perto dele" (Célia, 2015).

Ao longo do diálogo, dois estudantes relataram que tinham deficiência. $\mathrm{O}$ primeiro foi enfático em falar que tinha Síndrome de Asperger e que ele não se sentia diferente das outras crianças por apresentar essa síndrome: "Eu também tenho uma deficiência. Tenho doença de Asperger" (Conrado, 2015). O estudante Caio, aluno que a família não aceita o diagnóstico de transtorno global do desenvolvimento, relata que apresenta algumas deficiências. A criança não sabe expressar com clareza o que tem, mas sente que tem dificuldade na aprendizagem, dificuldade na audição, mas que é muito bom em fazer desenhos.

Assim como o Conrado falou que tem deficiência, eu também tenho algumas. Tenho um pouco de dificuldade para aprender e algum probleminha na audição. Quando minha mãe está longe e me chama, eu não escuto bem. Depois que eu fui ao médico, ele passou um remédio para eu tomar todos os dias e eu melhorei um pouquinho (Caio, 2015). 
O relato dessas duas crianças é bastante relevante, pois de mostra que elas sabem que possuem algumas limitações orgânicas, mas que isso não as impede de realizar nenhuma atividade proposta. Convém destacar a fala do aluno Caio, que tem a conotação de que ele compreende as suas limitações, mas, ligando com o depoimento do professor Carlos, percebese a dificuldade do estudante por não ter o apoio de sua família em buscar um diagnóstico apropriado. A família apenas aceita o diagnóstico de Transtorno do Deficit de Atenção e Hiperatividade - TDAH, ela não concorda que a criança também tem o transtorno global do desenvolvimento. Isso dificulta que sejam realizadas atividades adequadas para a necessidade do estudante, assim como o atendimento nos apoios especializados.

Quando questionado a respeito de práticas inclusivas, os estudantes possuem dificuldade de entender o que seria, mas conseguem identificar o trabalho do professor acerca de consciência racial como uma das práticas inclusivas e o pensamento do dia quando o professor apresenta frases com conteúdo de cunho moral, de respeito à diversidade e de inclusão.

Ao final do grupo focal, foi solicitado que as crianças fizessem alguns desenhos a respeito do que entenderam da inclusão e os seus aspectos mais relevantes. Foram selecionados alguns desenhos que expressam com clareza o entendimento das crianças em relação ao assunto. 


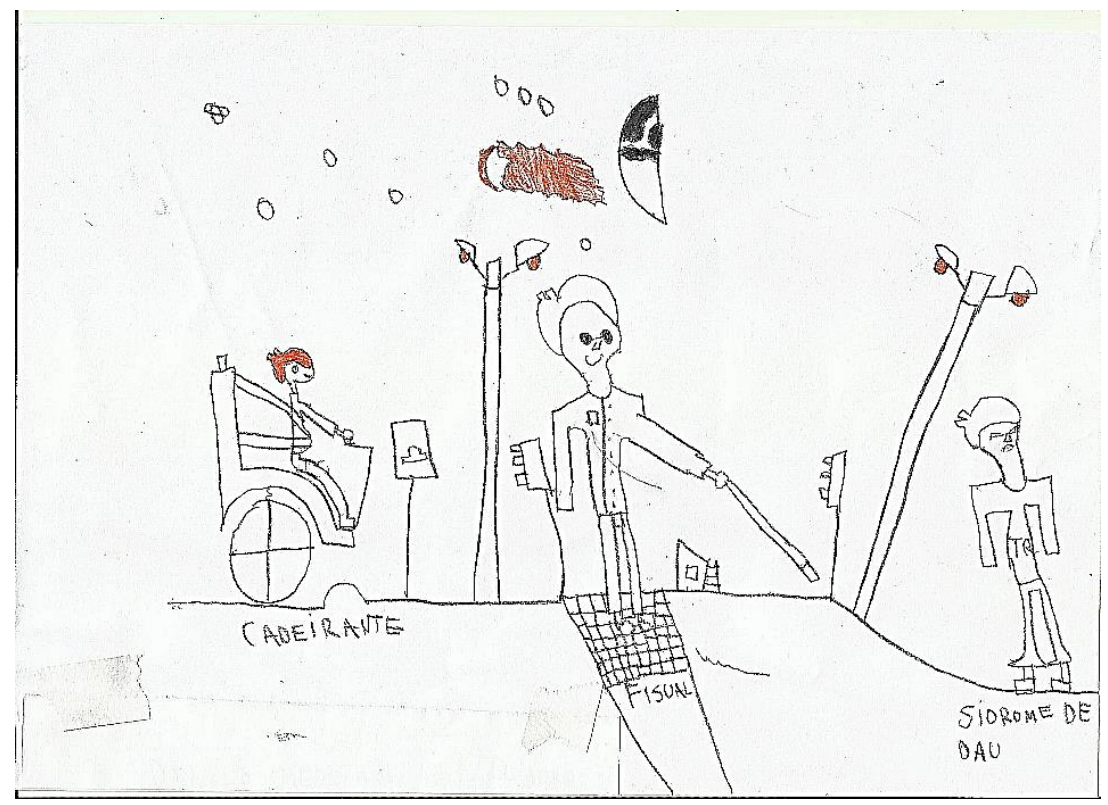

Figura 3 - Conrado

O estudante Conrado desenhou três pessoas com deficiência, sendo uma com deficiência física (pessoa com cadeira de rodas), uma com deficiência visual (usando óculos escuro, bengala e piso tátil) e outra com síndrome de down (com os traços físicos de uma pessoa com Down, por exemplo, os olhos puxados). Foi perguntado à criança a respeito da Lua no desenho e o aluno falou que a Lua tem deficiência visual, por isso está com os "olhos" com óculos. Isso de mostra que a criança entende que não apenas os seres humanos apresentam diferenças, mas até mesmo os outros seres são distintos uns dos outros.

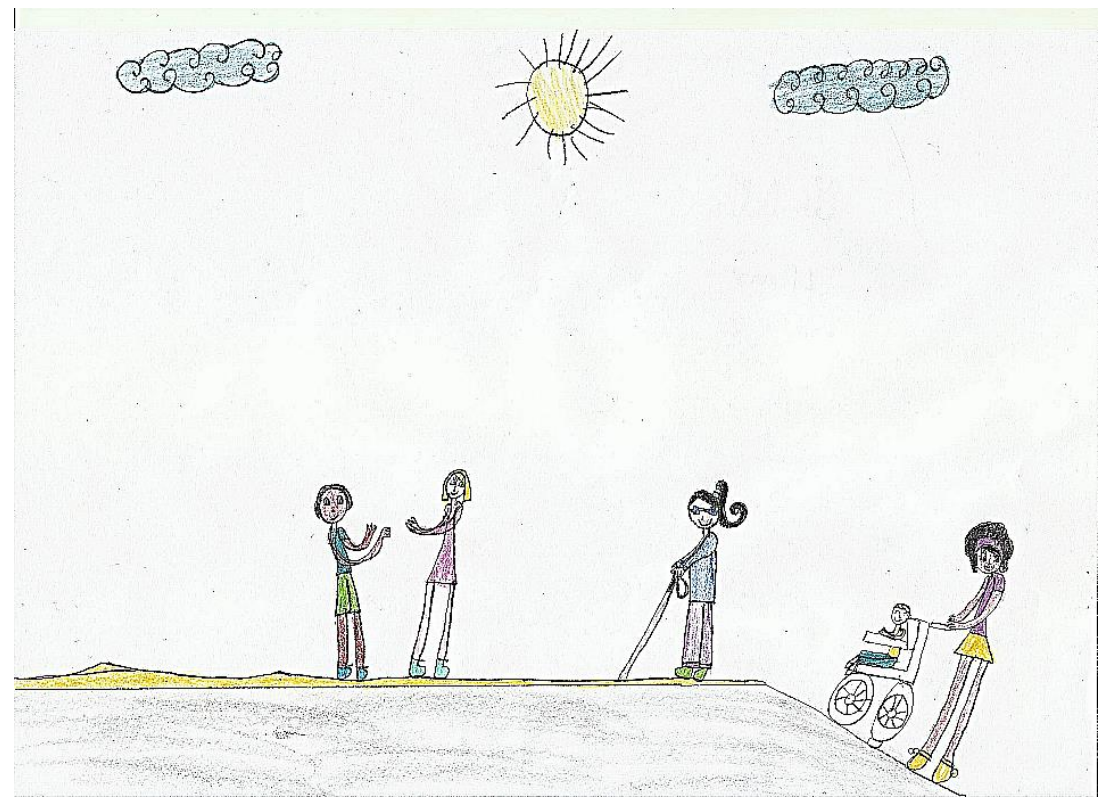

Figura 4 - Carolina 
No desenho da Carolina, também são apresentadas três situações de pessoas com deficiência. Na primeira figurada esquerda, a criança relatou que são pessoas que estão tendo um diálogo em Libras; a segunda é uma pessoa com deficiência visual e a terceira uma pessoa ajudando uma pessoa com deficiência física a subir uma rampa. Essas situações são corriqueiras no dia a dia das crianças, por isso aparecem com frequência. Quando a criança ilustra as pessoas tendo um diálogo em Libras, sinaliza que é possível que, naqueles espaços, esteja ocorrendo a inclusão, onde é possível que uma criança seja ouvinte e a outra surda.

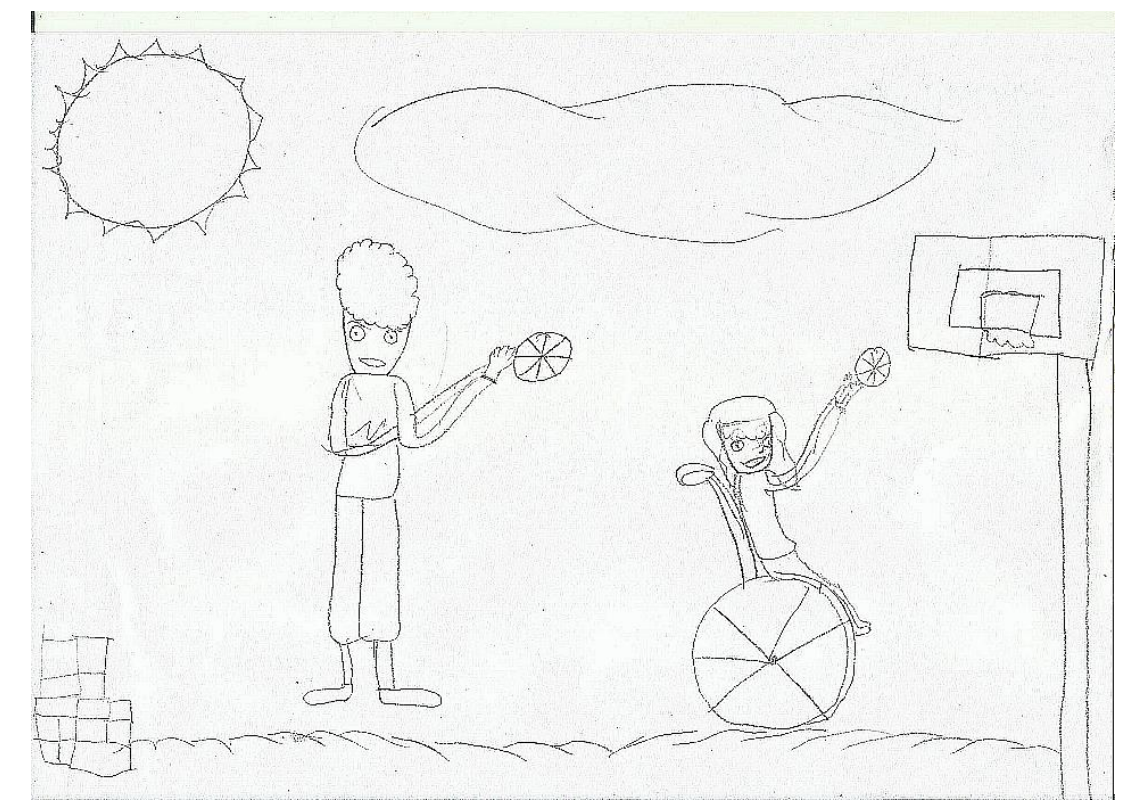

Figura 5 - Cristina

No desenho, Cristina ilustra uma situação de inclusão, onde são apresentadas duas pessoas: uma com deficiência física, cadeirante, e outra sem deficiência. Nessa ilustração, as crianças estão jogando basquete, ambas no mesmo espaço, o que demonstra estarem vivenciando uma situação de inclusão. A inclusão no jogo é o momento mais adequado para estimular regras e criar um bom espaço de convivência sem discriminações e preconceitos entre as pessoas. É possível identificar também que as duas pessoas apresentam características físicas bem diferentes: uma aparenta ser afro-descendente, por ter sido desenhada com cabelos bastante cacheados e a outra é uma criança de cabelos lisos. É importante destacar que ambos os jogadores possuem o braço do mesmo tamanho, mostrando que as duas são capazes de realizar aquela atividade física. 


\section{A ESCOLA DA ASA NORTE}

As análises realizadas na escola da Asa Norte são referentes ao Projeto Político Pedagógico, as observações realizadas em sala de aula, o questionário e a entrevista com o professor; e o grupo focal com os estudantes. Para uma boa interpretação dos dados, é importante levar em consideração a forma os dados foram obtidos e a realidade social na qual a escola está inserida.

\subsection{O Projeto Político Pedagógico da Escola}

O Projeto Político Pedagógico da escola da Asa Norte foi enviado para o e-mail da pesquisadora e informado que ainda era o PPP de 2014, pois o de 2015 ainda não estava vigente e totalmente finalizado. De início, foi percebido que o Projeto enviado não continha capa, o que contraria o solicitado pelas Orientações Pedagógicas da SEDF (2014).

De acordo com o documento apresentado, a construção do Projeto Político Pedagógico ocorreu por meio de reuniões coletivas pedagógicas, com os pais e os demais segmentos da escola. Foram utilizados como instrumentos de pesquisa questionário, estudos e atividades com as crianças (PPP ESCOLA DA ASA NORTE, 2014). Não foram apresentadas algumas das ilustrações realizadas pelas crianças, bem como não foram expostos os sujeitos que participaram dessa elaboração, o que dificulta a comprovação de uma construção coletiva do PPP.

As características da escola estão conforme as Orientações Pedagógicas (2014). Nesse item foram listados o corpo de servidores da escola, assim como o quantitativo de 212 alunos. Uma situação que merece destaque é não aparecer na lista de servidores da escola o cargo de Técnico de Assuntos Educacionais- Monitor, pois, quando realizada a observação de campo, foi informado que a escola tinha em seu quadro três Monitores, sendo que dois estavam em outras funções, como Direção e Secretaria, e o outro estava de licença médica.

Ao traçar o perfil dos alunos, a escola deixou evidente que, apesar de constar em seus arquivos que a maioria dos estudantes mora na Asa Norte, isso demonstra não ser um dado verdadeiro, porque muitos pais apresentam o endereço de seus trabalhos para conseguirem vaga em escola no Plano Piloto com a crença de que aquela localidade possui uma melhor qualidade de ensino. Sendo assim, "vale destacar que 41\% desses alunos residem em cidades satélites distantes da Instituição de Ensino (média de 30 quilômetros), como: Gama, Riacho Fundo, Recanto das Emas, Luziânia, Santa Maria e Samambaia” (PPP Asa 
Norte, 2014, p. 8). Esse dado é relevante, porque, com o desgaste do trajeto, as crianças ficam prejudicadas em seu rendimento escolar.

A escola faz questão de deixar claro em seu PPP que possui muitos alunos com deficiência e que promove tanto a sua inclusão em uma sala de aula regular quanto os que permanecem em classes especiais, o que faz a escola conseguir ter um bom rendimento para tentar realizar a inclusão no ano seguinte. No ano de 2014, a escola tinha 11 classes regulares inclusivas e sete classes especiais. Segundo dados constantes do projeto pedagógico em 2013, a escola tinha 12 alunos matriculados em classes especiais e, para o ano de 2014, foi possível realizar a inclusão de dois desses alunos em classes regulares inclusivas. Ainda é apresentado que dos 13 alunos em classes inclusivas no ano de 2013, 92.3\% tiveram aprovação para o ano seguinte (PPP Asa Norte, 2014). O PPP ainda destaca que os alunos que foram para classes inclusivas no ano de 2014, foram para cinco turmas de integração inversa (com número reduzido de alunos).

O Projeto apresenta como missão da escola o oferecimento de um ensino de excelência e de educação integral a todos os alunos, assim como a formação de cidadão crítico e participativo na sociedade.

Como princípio norteador de seu trabalho, a escola apresenta o princípio da Educação Integral, na qual o aluno deve ser visto na sua totalidade, como um ser único e singular, traz também conceitos de interdisciplinaridade e transversalidade para compreender o estudante como um todo.

O PPP da escola está pautado em concepções legais advindas da Constituição de 1988, assim como da LDB 9394/96. É pertinente ressaltar que a escola enfatiza a sua preocupação com a educação inclusiva, ao afirmar que "a nossa escola tem a tradição de ser inclusiva, assim sendo, toda a legislação pertinente à educação especial, seja ela internacional: Declaração de Salamanca, ou nacional: Decreto Viver sem limite, os quais são norteadores da nossa prática” (PPP Asa Norte, 2014, p. 15). Trazer a inclusão expressa no PPP demonstra que a escola está preocupada com a inclusão de seus alunos, pois, quando todos que construíram o Projeto Político Pedagógico se solidarizam com a causa, o trabalho efetivo para que isso seja cumprido é concretizado.

O Projeto Político Pedagógico da escola da Asa Norte informa, em seu documento que segue para a avaliação, as orientações das Diretrizes de Avaliação Educacional - Triênio 2014/2016 da Secretaria de Estado de Educação do Distrito Federal. Sendo assim, esse documento apresenta expressamente que 
$\mathrm{Na}$ Educação Especial, a avaliação para as aprendizagens deve ser considerada, observando as especificidades de cada estudante (público-alvo) dessa modalidade de atendimento, conforme estabelecido pela Lei de Diretrizes e Bases da Educação Nacional 9.394/1996, no artigo 58, a saber: estudantes com deficiência, transtornos globais do desenvolvimento (TGD) e altas habilidades/superdotação (AH/SD). (SEDF, 2014, P. 19)

Trazendo essa Diretriz de Avaliação Educacional para dentro do PPP, a escola garante que todos os estudantes que apresentam alguma deficiência, transtorno global do desenvolvimento e altas habilidades serão avaliados segundo as suas especificidades.

Vale ressaltar que, no projeto pedagógico apresentado, não consta nenhum tópico que especifica com clareza os objetivos da escola para a Educação Inclusiva. Destaca-se que, a partir de janeiro de 2016, pela Lei Brasileira de Inclusão (BRASIL, 2015), todas as escolas terão que especificar pelo menos um tópico em seu PPP acerca da institucionalização do atendimento educacional especializado e demais serviços, visando ao pleno acesso do estudante ao currículo em caráter de igualdade e promovendo a conquista de sua autonomia.

Assim como solicitado nas Orientações Pedagógicas (2014), a escola apresenta a sua organização curricular, o horário de entrada e saída de cada turno, bem como as oficinas que são ministradas na educação integral e os seus objetivos. É ressaltado que os pais e a comunidade escolar participam de reuniões bimestrais e de eventos festivos realizados na escola. São apresentados os horários de atendimento na Escola Parque, no Serviço de Apoio Especializado, na Sala de Recursos, na Sala de Apoio Pedagógico, na Atendimento Psicopedagógico, na Biblioteca e na Sala de Informática.

Como estratégias de avaliação, a escola utiliza a avaliação diagnóstica e a avaliação formativa, utilizando instrumentos como: trabalhos, provas, sondagens, observação, autoavaliação e psicogênese, entre outras formas de exame. Também são utilizados para a avaliação instrumentos externos, como a Provinha Brasil, a Avaliação Nacional de Alfabetização - ANA e o Sistema de Avaliação da Educação Básica - SAEB.

Em sua organização curricular, a escola apresenta uma proposta para implementar o Currículo Integrado, assim como sugerido nas Orientações Pedagógicas (2014). Há um estudo dos eixos transversais e os temas são divididos por determinadas ideias. Esta parte do PPP é bem delimitada, onde são apresentadas propostas para cada um dos anos iniciais e para a Educação Especial conteúdo a conteúdo e uma estratégia de como trabalhar os temas.

Os planos de ação para o desenvolvimento do PPP são bem delimitados e possuem estratégias, objetivos e metas que esperam ser alcançadas com essa implementação. 
A escola da Asa Norte apresenta um Projeto Político Pedagógico bem elaborado, que atende os requisitos das Orientações Pedagógicas (2014). Ela tem objetivos e estratégias para alcançar metas de ensino e aprendizagem.

\subsection{Professor Antônio: formação e posicionamentos}

O professor Antônio ingressou na Secretaria de Educação do Distrito Federal em 2005, por meio de concurso público que na época aceitava o Magistério como formação para a atuação no Ensino Fundamental, anos iniciais. No mesmo ano, ingressou no curso de Pedagogia da Universidade de Brasília tendo sua formação concluída em 2010. Ele não tem nenhuma especialização sirito ou lato sensu, mas informou que está cursando uma segunda graduação em Educação Física. Expõe que ainda não realizou nenhuma especialização por estar desmotivado com os professores da UnB, pois acredita que eles estão desatualizados e não acompanham a dinâmica apresentada nas salas de aula.

Eu poderia estar com uma pós-graduação, mestrado ou doutorado, mas eu escolhi fazer uma segunda graduação, pois sempre quis fazer o curso de Educação Física. O que me afasta do meio acadêmico é ver que uma pessoa é doutora, mas não consigo visualizar a sua contribuição para a educação. Às vezes a pessoa nunca alfabetizou nenhuma criança, mas está lá em sala de aula falando sobre alfabetização (Professor Antônio, 2015).

O discurso do professor Antônio demonstra uma total falta de interesse em realizar atualizações que seriam importantes para o seu desempenho e a sua prática em sala de aula dos anos iniciais do Ensino Fundamental. Concordando com Pimentel (2012, p. 153), “o processo de formação continuada nas escolas deve ser pautado nas discussões sobre a prática subsidiada na teoria e deve ser obrigatória para todos os docentes, não apenas para aqueles que estão ministrando aulas para estudantes com deficiência”. Realizar uma segunda graduação é excelente para o currículo do professor, mas, aliado a isso, ele poderia realizar a cada semestre cursos ofertados pela Escola de Aperfeiçoamento dos Profissionais da Educação - EAPE os quais agregariam conhecimento e até mesmo influenciariam sua postura em sala de aula com os estudantes. Concordando com Ferreira e Ferreira (2013), existe uma ausência de políticas públicas para a formação continuada de professores. Essa carência permite que o docente não busque novas formas de capacitação, o que permite que seus conhecimentos acerca do assunto fiquem obsoletos. 
Em sua graduação em Pedagogia, o professor Antonio cursou as disciplinas " $\mathrm{O}$ Educando com Necessidades Educacionais Especiais" e "Aprendizagem e desenvolvimento do PNEE”. Relatou que as disciplinas ajudaram bastante em sua atuação profissional, pois permitiram que ele desenvolvesse uma visão positiva da criança, embora ele acredite que não teve um ganho real, pois não teve como aliadas as experiências práticas.

As disciplinas ajudam bastante, sim. Você adquire conhecimento sobre a Declaração de Salamanca, o que auxilia na construção de uma visão positiva da criança, dentre outras coisas. Para isso acontecer, deve haver um interesse do aluno e ter como aliada uma vivência prática, para existir um verdadeiro ganho real (Professor Antônio, 2015).

O docente Antônio acredita que devam existir mudanças nas disciplinas ofertadas pela Faculdade de Educação. Segundo o docente, é necessário que exista mais prática e seu acompanhamento, tanto pelos professores da UnB quanto pelos profissionais da Secretaria de Educação do DF: “Tem que haver mais prática e o acompanhamento dela. Tanto por profissionais da UnB, que são responsáveis pela formação, quanto pela Secretaria de Educação" (Professor Antônio, 2015). É necessário que haja mais prática na Universidade de Brasília, pois, como apresentado na leitura de seu Projeto Acadêmico, percebe-se que há um deficit de horas de estágio supervisionado, a ser executado, para que o curso atenda as exigências legais do MEC. De acordo com Góes (2013), a formação de professores para a inclusão em algumas universidades do Brasil também não consegue aprofundar temas relativos à deficiência nem atividades práticas satisfatórias. Dessa forma, fica evidente que deve existir uma relação mais próxima entre teoria e prática em todas as disciplinas ofertadas pelo curso de Pedagogia.

\footnotetext{
A formação das alunas não tinha propiciado o estudo de tópicos a respeito dessa área, exceto por menções genéricas e raros textos incluídos em poucas disciplinas; além disso, apenas algumas entrevistadas tiveram, em seus estágios, oportunidades de contato com alunos especiais, que propiciaram uma aprendizagem muito restrita (GÓES, 2013, p. 73).
}

Outros momentos de prática e de contato com estudantes com deficiência também são solicitados, por meio da observação apresentada por Góes (2013). O deficit na formação para a educação especial e inclusiva é sentida também em outras Universidades além da Universidade de Brasília. Em um estudo apresentado por Martins (2012), vários graduandos dos cursos de licenciatura da Universidade Federal do Rio Grande do Norte - UFRN acreditam que os cursos devem ter: 
Inclusão de mais de uma disciplina voltada para a Educação Inclusiva, em caráter obrigatório, em todas as licenciaturas. Ampliação da carga horária das disciplinas que vêm sendo desenvolvidas. Desenvolvimento de atividades que proporcionem um maior contato com as pessoas com deficiência, altas habilidades/superdotação e transtornos globais do desenvolvimento, tais como visitas a escolas e associações atuantes na área, entrevistas, palestras com profissionais convidados, aulas práticas. Discussões sobre dificuldades comuns encontradas na sala de aula por docentes e como enfrentá-las, de maneira a realizar uma maior correlação entre teoria e prática educativa. Interação de conteúdos relativos às pessoas com necessidades educacionais especiais em outras disciplinas oferecidas nas licenciaturas. Ampliação de atividades extracurriculares na área, no âmbito da UFNR, tais como seminários, cursos, oficinas, entre outros (MARTINS, 2012, p. 31-32).

As solicitações, feitas pelos próprios estudantes dos cursos de licenciatura e pelos professores que já terminaram a sua formação inicial e estão em sala de aula, por mais momentos de prática e de discussões sobre dificuldades encontradas em classe com estudantes com deficiência estão evidentes e eles solicitam que sejam tomadas providências por parte do Ministério da Educação e das Universidades. Esses órgãos devem observar esse pedido dos estudantes que vão para a sala de aula e percebem que estão despreparados para lidar com a diversidade de estudantes que encontram. Medidas em caráter de urgência devem ser tomadas visando ao cumprimento do acordo que o Brasil firmou na Convenção sobre os Direitos das Pessoas com Deficiência (2007) em tornar toda a Educação Inclusiva.

O docente Antônio também acredita que os professores que ministram as disciplinas na Faculdade de Educação devam possuir uma vivência prática do que ensinam, porque ele acredita que, se um curso de medicina possui momento de prática junto com os professores, a educação também necessita desse espaço e de professores que comprovadamente já tenham atuado com aquelas situações expostas em sala de aula. Para ele, caso não ocorra desta forma, sempre haverá muita teoria e pouca prática: "Os professores que ministram essas disciplinas devem ter uma vivência prática comprovada. Como que você ensina um autista se você nunca trabalhou com um autista?" (Professor Antônio, 2015). A prática tanto enfocada pelo professor é incentivada por Imbernón (2006) que acredita que, por meio de uma formação baseada em problemas, em situações vivenciadas no dia a dia nas instituições escolares, começa a existir um maior incentivo à pesquisa. Então, é necessária uma mudança no perfil de professores que atuam na UnB, enfocando mais momentos práticos aliados à teoria.

A Universidade de Brasília possui em seu corpo docente excelentes profissionais que às vezes, por excesso de trabalho (ministrar aulas, publicar artigos e burocracias internas), 
ministram aulas descontextualizadas do dia a dia das escolas públicas. Mesmo com tudo isso, por que a prática não é incentivada na Universidade? Concordando com Imbernón (2006), a formação de professores não pode ser unicamente por meio da transmissão de conhecimento, ela deve ser pautada em experiências compartilhadas no interior das escolas. Essas experiências só poderão ser vivenciadas, se o aluno for instruído a ir à sala de aula realizar observações de campo e viver na prática situações corriqueiras de uma turma, trazendo, dessa forma, situações-problemas para serem discutidas com seus pares.

O docente Antônio começou a atuar na Educação Especial em 2010 em uma turma que tinha uma criança autista clássica. Depois trabalhou com crianças com deficiência intelectual e novamente com o autismo.

A primeira vez que tive um aluno autista foi em 2010, em uma turma do quarto ano. Era um autista clássico e com muita dificuldade de se relacionar com as outras crianças. Em um primeiro momento, não existia sala de recursos na escola, apenas depois chegou um profissional para trabalhar com o aluno. Também tive uma criança diagnosticada com Deficiência Intelectual, mas eu não acredito que ela tenha. Infelizmente eu não sou médico. A criança chegou ao quarto ano sem saber ler e escrever, apenas por isso ela foi diagnóstica com DI. Eu acredito que foi falta de estímulo, foi um problema da escola e não do aluno. Como que uma criança com DI aprende toda a matemática que não aprendeu até o quarto ano em apenas um ano, tirando só notas oito, nove e dez? Embora eu tenha colocado em seu relatório que o seu problema não era de raciocínio, mas, sim, de alfabetização, que a comunidade da qual a criança veio tem uma realidade terrivel, mesmo assim a rotularam para o resto da vida (Professor Antônio, 2015).

Essa exposição do professor é importante porque retrata a realidade de muitas crianças. De acordo com Orrú (2012, p. 187), "os critérios de diagnóstico acusam e classificam incapacidades, problemas, deficits, anormalidades de maneira que se possam categorizar as pessoas segundo resultados homogêneos". Muitas vezes os estudantes são diagnosticados de forma errada por diversos motivos, tais como: erro médico ou até mesmo uma forma da escola eliminar um problema que não consegue resolver. Esse segundo caso implica fortemente a escola, pois alguns profissionais chegam a realizar tais diagnósticos "errados" para justificar o porquê de a criança não conseguir aprender, ao invés de identificarem que existe de fato um problema de ensino e não de aprendizagem ocorrendo. Esse problema de ensino, na maioria das vezes, é camuflado pela escola, por meio de um encaminhamento para a sala de recursos, para os serviços de apoio especializado e para atendimento médico, por não conseguirem obter do professor de sala uma nova postura no trabalho com o estudante. 


\section{Inclusão}

Como conceito de inclusão, o professor faz uma diferenciação entre inclusão e integração, sendo assim, o docente entende que, para que a inclusão ocorra, deve existir um senso de pertencimento de entendimento de que todos devem viver como iguais, diferentemente do que ocorre com a integração na qual as pessoas estão juntas, mas não estão necessariamente incluídas, não existe nesse caso um senso de pertencimento ao local.

Atualmente o termo inclusão parece se referir ao fato de Alunos Especiais frequentarem Classes Regulares no âmbito da Secretaria de Educação em escolas públicas elou particulares. Chamo a atenção para o fato de que 'estar junto' ou 'frequentar o mesmo' local (sala de aula) não implica necessariamente estar incluído. Um exemplo simples: Você pode ir a uma festa, ou um show, com algumas milhares de pessoas ao seu redor e ainda assim estar sozinho. Como? Se não há empatia, identidade, se não existem laços afetivos. Inclusão vem, antes de tudo, de laços afetivos, de relações verdadeiramente humanas! É preciso que exista um senso de identidade, de pertencimento! Isso é a verdadeira inclusão! Seres humanos educam-se mutuamente no exercício de conviver (viver juntos), coexistir. Nesse contexto, as deficiências ou necessidades educacionais especiais, passam a ser vistas com naturalidade. Como apenas mais uma das diferenças que precisam ser entendidas e respeitadas para o bem-estar de todos, para a convivência harmoniosa e pacífica (Professor Antônio, 2015).

$\mathrm{O}$ docente Antonio compreende que existe uma diferença significativa entre integração e inclusão. Conforme ele expôs, a inclusão está relacionada ao senso de pertencimento da pessoa ao lugar e de seu acolhimento. Ainscow (2007) compreende que a integração ocorre quando o aluno com deficiência ingressa na escola e esta precisa promover medidas adicionais para atender essa demanda; ao contrário da inclusão, que pretende reestruturar as escolas de modo a atender a necessidade de todas as crianças. Ao compreender que todas as crianças necessitam de uma reestruturação escolar, a inclusão começa a ocorrer. Vale destacar que o professor sabe diferenciar claramente os conceitos, porém não consegue aplicar a inclusão em sala de aula, pois age de forma excludente para com o aluno com autismo.

Algumas de suas atitudes também corroboram para essa conclusão, pelo fato de deixar o aluno isolado do restante da turma, em uma carteira ao fundo da classe, por não permitir que os outros estudantes sejam seus pares durante a aula e que o aluno apenas possa ter o contato com eles na hora do intervalo ou na execução de algum jogo. Concordando com Ferreira (2009, p. 43), "recusar matricula, matricular e isolar na sala de aula, impedir o contato com os colegas configuram-se atos discriminatórios e violações graves do direito de 
qualquer estudante à educação e à convivência em condições de igualdade". Como observado, a violação do direito à educação e a convivência com seus pares foram totalmente infringidos na sala de aula da Asa Norte, pois o aluno ficou desamparado legalmente dos seus direitos básicos que são assegurados pela Constituição Federal.

O que pode ser compreendido dessa situação é que o docente aplica, de forma eficaz, a integração em sala de aula, onde o aluno não se sente parte da turma, ficando na maior parte do tempo isolado e sem interação com o restante da classe.

\section{Desafios}

Os principais desafios a serem enfrentados estão no interior das próprias escolas, pois as escolas públicas estão longe de estarem preparadas para receber os estudantes com deficiência e, até mesmo, os sem. Sendo assim, é necessário que o Estado ofereça condições para que as escolas possam funcionar realmente como centro de referências.

A sala de recursos deve ser um aliado do professor, pois ela é um dos principais instrumentos que auxiliam o aluno no desenvolvimento de habilidades que o professor de sala de aula não consegue desenvolver. De acordo com a Política Nacional de Educação Especial na perspectiva da Educação Inclusiva (2007), a sala de recursos é parte integrante do Atendimento Educacional Especializado - AEE. Esse atendimento tem por função

identificar, elaborar e organizar recursos pedagógicos e de acessibilidade que eliminem as barreiras para a plena participação dos alunos, considerando suas necessidades específicas. As atividades desenvolvidas no atendimento educacional especializado diferenciam-se daquelas realizadas na sala de aula comum, não sendo substitutivas à escolarização. Esse atendimento complementa e/ou suplementa a formação dos alunos com vistas à autonomia e à independência na escola e fora dela (BRASIL, 2007, p. 10).

Na escola da Asa Norte, não existe mais um profissional na sala de recursos, pois ele assumiu uma função na direção da escola. Diante disso, é necessária uma breve reflexão acerca do que é prioridade dentro de uma escola: o atendimento de alunos com deficiência por um profissional especializado ou um cargo na direção? É entendido que a função principal da escola é o ensino, sendo assim, os alunos não podem ser prejudicados devido à ausência desses profissionais. Portanto é obrigação da Secretaria de Educação do DF remanejar um professor para substituir esse que assumiu função ou não permitir que profissionais que são essenciais sejam retirados de suas funções principais para assumir outras secundárias que podem ser executadas por outros profissionais. Essa atitude da escola em ficar sem um profissional no Atendimento Especializado prejudica os estudantes que estão inclusos em 
salas de aulas regulares, pois eles não terão suporte nem auxílio na eliminação de barreiras que ajudam na inclusão.

O Monitor para estudantes com deficiência é um aliado na tarefa do professor, porque o seu trabalho é contemplado como umas das formas de promover a inclusão. No âmbito nacional, esse servidor é conhecido como profissional de apoio. Conforme a Nota Técnica nº19 de 2010 (BRASIL, 2015), ele tem a função de promover a acessibilidade e o atendimento às necessidades específicas dos estudantes com deficiência, tais como, cuidados com a alimentação, higiene e locomoção dos alunos que não realizam essas atividades com independência. A Nota ainda deixa evidente que "não é atribuição do profissional de apoio desenvolver atividades educacionais diferenciadas, ao aluno da escola pública alvo da educação especial, e nem se responsabilizar pelo ensino deste aluno" (BRASIL, 2015, p. 145). Desse modo, no âmbito do Distrito Federal, foram criadas as leis $n^{\circ} 5106$, de 2013, e a portaria n³8 para discutirem as atribuições dos Monitores na SEDF.

De acordo com a Lei no 5106 de 2013, é função do monitor o "suporte operacional às atividades de cuidado, higiene e estímulo de crianças no âmbito de competência da Secretaria de Estado de Educação" (SEDF, 2013, p. 2). Por meio desse suporte, o professor poderá realizar um trabalho mais eficaz para o estudante e para toda a turma. Conforme a portaria $\mathrm{n}^{\circ} 38$ de 2013, os Monitores deverão atuar prioritariamente com os estudantes com deficiência e Transtorno Global do Desenvolvimento, e o seu envio para Classes Especiais deve ocorrer, se houver um estudante com Deficiências Múltiplas - DMU em sala de aula. Concordando com Sanchez (2009), é relevante compreender que a questão dos "auxiliares" não deve ser compreendida como uma delegação e separação de funções, mas um processo de colaboração e de responsabilidade compartilhada.

Para o caso do aluno autista do professor Antônio, o Alisson, o Monitor foi requisitado via ordem judicial. Essa requisição ao juiz foi necessária, porque, apesar de o estudante se enquadrar nos casos de envio de monitor, dispostos na portaria $\mathrm{n}^{\mathrm{o}} 38$ de $2013 \mathrm{e}$ na Estratégia de Matrícula 2015 e 2016, a Secretaria de Educação não enviou monitor para auxiliar o estudante. A necessidade da família em precisar entrar com ação no Ministério Público para que um atendimento de direito do estudante ocorresse demonstra que a SEDF não está preocupada em cumprir os dispositivos legais e reafirma, com esse fato, que também não está preocupada com a forma como a inclusão está sendo executada nas escolas. $\mathrm{O}$ docente lamenta que seja enviado um único Monitor para atender toda a escola: 
Quando a Secretaria de Educação envia um Monitor, eles enviam um para a escola inteira. $O$ que não adianta, porque cada criança com deficiência necessita de um Monitor que atenda exclusivamente às suas necessidades. No caso do meu aluno, o Monitor veio por ordem judicial e, ainda assim, quando ele se ausenta, entra de atestado médico, esse atestado anula a decisão judicial?(Professor Antônio, 2015).

O caso que está sendo explorado pelo professor Antônio faz referência ao fato de ele estar sem um Monitor em sala de aula por quase 30 dias, após ele entrar de licença médica. O docente contesta a falta de planejamento existente na Secretaria de Educação que não enviou nenhum outro servidor para cumprir essa ausência. Na SEDF, não existe nenhuma lei ou portaria que regulamente a substituição de Técnicos de Assuntos Educacionais Monitores em sua ausência, o que gera lacunas nas escolas. O que deveria ser feito é a contratação de profissionais temporários, assim como ocorre no caso dos professores, para suprir essa ausência durante o período de afastamento do servidor. Outro ponto nessa situação que merece destaque é o fato de o Monitor estar sendo tratado como exclusivo dos estudantes. Nessa questão, Crochík (2012, p. 44) acredita que "esse profissional passa a ser conhecido como sendo próprio a esses alunos o que configura uma segregação dentro da própria sala de aula, o que, a nosso ver, fortalece o preconceito, não o combate". Como retratado por Crochík, a partir do momento que o Monitor é visto como exclusivo do aluno, essa atitude gera segregação para com os outros estudantes e não uma inclusão do aluno com deficiência.

O professor Antônio relata que as famílias de estudantes autistas usualmente são bem presentes na escola, apoiam o trabalho dele e realmente se interessam e se preocupam com as necessidades da criança na escola: "Geralmente, famílias de crianças autistas são bem presentes, apoiam e se interessam pelo desenvolvimento do aluno. Até mesmo por uma questão de necessidade, porque não é fácil lidar com essas crianças". É fundamental que exista um bom relacionamento entre o docente e a família, porque, sem essa interação ,não é possível realizar um trabalho adequado. De acordo com Ferreira e Ferreira (2013), os estudantes com deficiência dependem de suas famílias para conseguirem que na escola se criem as condições necessárias para que elas possam estar presentes nas salas de aula. Essa afirmação comprova-se verdadeira, porque, nas escolas em que os pais e a família estão presentes, os estudantes conseguem ter uma educação de melhor qualidade e uma aprendizagem voltada para a sua necessidade. Por outro lado, nem sempre isso acontece, pois não depende só da presença da família, mas do interesse de todos os envolvidos nesse processo, principalmente da escola e do professor da sala de aula. 


\section{Práticas Inclusivas}

Para o trabalho com a inclusão, é necessário "criar um clima de tranquilidade $e$ cooperação em sala de aula, assim como ter domínio da turma e as crianças estarem tranquilas" (Professor Antônio, 2015). O professor Antônio acredita que esse processo permite que todos sejam parte do processo. Também é preciso que a criança saiba o propósito dela estar em sala de aula e que exista um nível de interação entre todos.

Diferente do apresentado na entrevista pelo professor, foi observado, em sala de aula, que os alunos da turma do professor Antônio são bastante agitados e, muitas vezes interrompem o professor na hora de sua explicação ou momento de ensino com o aluno autista. Em alguns momentos, o aluno fica prejudicado em sua aprendizagem pela agitação da turma que o distrai e tira seu foco. $\mathrm{O}$ docente, quando questionado acerca dessa postura da turma, falou que o problema é que ele possui uma turma bem diversificada, tendo em sua sala o aluno autista e outros dois com transtorno do deficit de atenção e hiperatividade - TDAH, o que tornam a turma agitada.

Eu trabalho com uma turma do quinto ano, mas existem crianças que ainda não sabem ler nem escrever. Eu as alfabetizo. Eu atendo ao DPAC (Distúrbio do processamento auditivo central), ao DI (deficiente intelectual), ao TDAH (transtorno do deficit de atenção e hiperatividade) $e$ ao autista. Qual a mágica para trabalhar com essa diversidade? (Professor Antônio, 2015).

Na Secretaria de Educação, essa diversidade de alunos é permitida em sala de aula, por meio da Estratégia de Matrícula, o que corrobora para a inclusão, porque, por meio da heterogeneidade de alunos, o professor pode criar estratégias para trabalhar os conteúdos com os estudantes, privilegiando os seus conhecimentos e estimulando a descoberta, sempre respeitando o desenvolvimento de casa estudante.

Outro fator que o professor Antônio apresenta para essa falta de domínio é a ausência de um monitor em sala de aula para acompanhar o aluno com autismo. Ele informa que o discente tem direito a esse profissional, porém este estava de atestado médico e permaneceria assim pelos próximos 30 dias. O trabalho do monitor com o aluno Alisson em sala de aula é solicitado quando ele está em momentos de agitação ou autoagressão. Nessas ocasiões, o servidor retira o estudante da sala de aula e o acompanha até a quadra ou o pátio. Essa retirada de sala visa à manutenção da integridade dos demais discentes da turma e da própria criança. 
Não foi possível observar o trabalho do monitor com o aluno autista, porque, nos dias de observação, ele estava de licença médica e regressaria à escola apenas após 30 dias. $\mathrm{O}$ professor Antônio queixa-se diversas vezes da ausência do profissional e justifica que, muitas vezes, o seu trabalho não pôde ser executado com eficiência por conta dessa carência. O número elevado de reclamações pelo professor deixou subentendido que ele somente consegue trabalhar com a turma quando o estudante Alisson está acompanhado do Monitor, pois este serve como uma forma de entretenimento para o aluno.

É observado que o professor tenta utilizar jogos para promover uma interação entre todos os estudantes da turma, mas essa prática não consegue chamar a atenção do aluno com autismo que tem grande dificuldade em permanecer no jogo, chegando até mesmo a chorar e se autoagredir para não participar da atividade. Por fim, o professor utiliza o recurso do tablet para promover um pequeno momento de aprendizagem. O que deve ser levado em consideração na utilização dos jogos ou até mesmo do tablet é o uso contínuo desses materiais. Concordando com Ferreira e Ferreira (2013) com a utilização desses materiais continuamente, as práticas nunca irão mudar e poderão tornar-se uma prática pedagógica generalizante, na qual serão reforçados os mesmos processos homogeneizantes. O uso contínuo de jogos pode trazer bem-estar para o estudante, por sair do ambiente de sala de aula, mas também pode representar uma prática repetitiva, quando executada diversas vezes em um curto período.

O uso do jogo, quando utilizado de forma que integre todas as crianças, até mesmo as com deficiência ou transtorno global do desenvolvimento, promove uma ação pedagógica capaz de ensinar e provocar a aprendizagem nas crianças. $\mathrm{O}$ uso do tablete apenas pelo aluno com autismo gera uma exclusão social dos demais estudantes que não possuem esses recursos tecnológicos. Apesar de o instrumento ser disponibilizado pela família do estudante, não convém que os outros presenciem essa prática diferenciada em sala de aula e não possuam o mesmo recurso ou um similar para também executarem as suas atividades. Essa situação gera uma situação de exclusão tecnológica dos outros integrantes da turma.

O professor Antônio apresenta diariamente ao aluno com autismo a agenda do dia ou agenda da rotina. Nela o professor mostra ao aluno as atividades que serão executadas com as respectivas fotos do aluno executando-as. Essa agenda das atividades é bastante utilizada com os estudantes autistas de todos os níveis. Ela apresenta mais ou menos o seguinte formato, uma foto do estudante executando a atividades e o nome de cada atividade. 


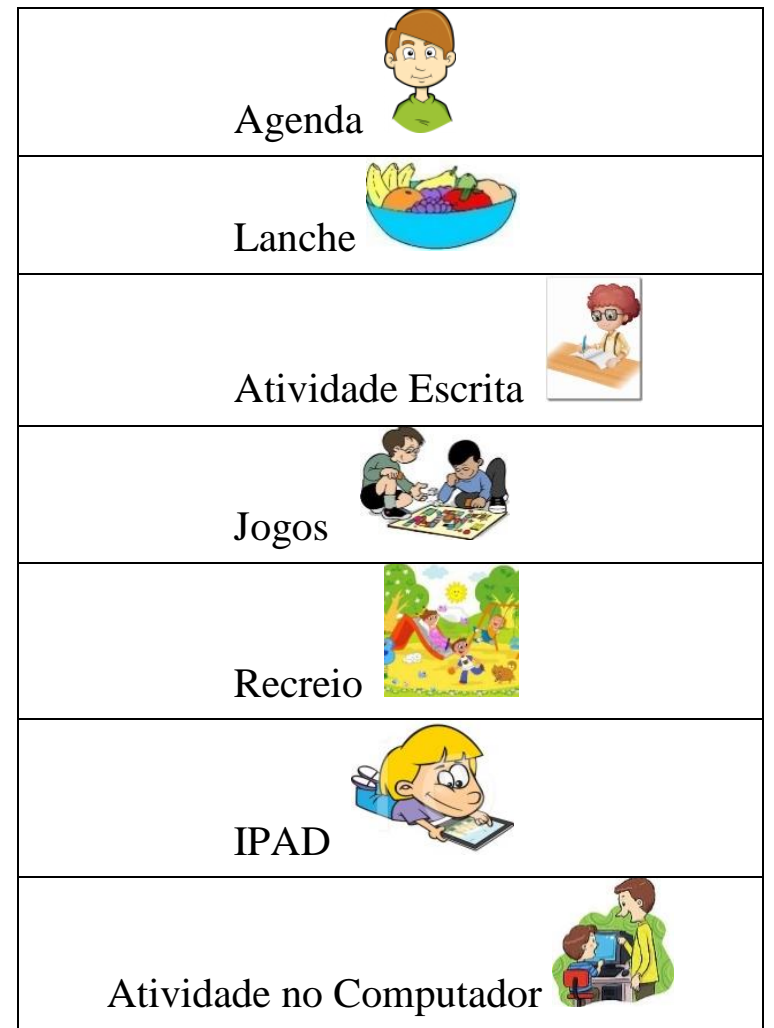

Tabela 3 - Agenda da Rotina

Essa é uma prática inclusiva que favorece a aprendizagem do aluno autista em sala de aula, não o deixando ansioso sem saber o que será realizado naquele dia e para que ele não se frustre.

O professor Antônio compreende que, no caso das crianças autistas, é necessário que aprendam primeiramente a terem um relacionamento com o mundo, sendo indispensável que ocorra uma adequação dos conteúdos aprendidos em sala de aula à necessidade da criança. Isso faz que ele saiba aplicar aquilo que está aprendendo, porque fará mais sentido para ele e facilitará a aprendizagem.

Ele precisa aprender a relacionar-se com o mundo ao seu redor, porque ele não precisa saber que a Amazônia está no Norte, mas sim coisas imediatas. Então, eu penso que é a educação que deve se adequar à necessidade da criança. Ela precisa aprender português, mas também precisa saber identificar qual é o banheiro masculino e qual o feminino, qual o ônibus que irá pegar, ter noção de direção para poder se localizar etc. Coisas que tenham um sentido mais prático (Professor Antônio, 2015).

O conhecimento de coisas cotidianas também faz parte da aprendizagem de crianças com deficiência, pois muitas vezes, por apresentarem um desenvolvimento cognitivo 
atrasado, não conseguem desenvolver essas noções no interior de suas residências, tornando, assim, uma parte do aprendizado destinado a escola. De acordo com Góes (2013, p. 82),

a formação para a cidadania e o respeito à pluralidade cultural são destaques da proposta da escola democrática e inclusiva, o aluno especial precisa formar-se como cidadão participante e ativo também no plano de um dos coletivos aos quais pertence, de indivíduos historicamente negligenciados no acesso a benefícios da cultura.

Essa colocação justifica o pensamento do professor Antônio em compreender que é fundamental formar o estudante com deficiência para a cidadania e o respeito para com a diversidade, ao invés de ele apenas ficar cercado de conhecimento de português, matemática e ciências, entre outras disciplinas. Essa construção cidadã pode permitir que o estudante se sinta parte do local onde vive.

Para a inclusão do aluno autista em uma sala regular, foram realizadas algumas adaptações curriculares que vão desde o horário de chegada aos conteúdos curriculares. Concordando com Pimentel (2012, p. 143),

para que o professor promova a adaptação curricular de modo a assegurar o atendimento à diversidade existente em sua sala de aula, ele precisa refletir sobre o currículo proposto, questionar os conteúdos existentes e objetivos previamente definidos, tendo como parâmetro a realidade de sua turma. [...] adaptar o currículo não significa propor um currículo diferenciado, mas adequar aquele conteúdo, aquele tempo previsto para aprendizagem à realidade de seu grupo de estudantes.

Desse modo, a adaptação curricular vai além de apenas uma adaptação de conteúdo e promove também uma adequação de espaços e tempos. O horário de permanência do estudante Alisson na escola é reduzido a pedido da família e em consonância com a escola, pois o estudante não consegue manter-se por muito tempo dentro de automóveis. Sendo assim, seu horário de chegada à escola é às 8h30 e sua saída, às 11:30.

Os conteúdos trabalhados com o estudante são referentes ao primeiro e ao segundo anos do Ensino Fundamental. Em sua pasta de atividades, foi possível identificar atividades acerca das vogais e do alfabeto. Isso demonstra que o estudante está realizando exercícios que não condizem com sua matrícula no quinto ano. A realização dessas atividades é prevista na adequação curricular do aluno e faz parte da inclusão. Em alguns momentos, o professor Antônio comentou que a presença do aluno autista acontece para que ocorra uma socialização e não convém retê-lo em outras séries por não conseguir acompanhar o conteúdo previsto. 
O aluno Alisson tem resistência em realizar atividades em folha por apresentar dificuldade motora que atrapalha sua escrita. Nesse momento, deveriam ser utilizados recursos de tecnologia assistiva ${ }^{4}$, para que o aluno não tenha dificuldade em sua realização e, assim, se senta estimulado em realizar as atividades. O professor da sala de aula, o professor da sala de recursos ou outro profissional da escola não buscaram auxílio para produzir esse material que facilitaria a escrita do aluno. O papel de elaborar um procedimento diferenciado seria da sala de recursos, de acordo com a Política Nacional de Educação Especial na Perspectiva da Educação Inclusiva (2007, p. 10), com a execução de "programas de enriquecimento curricular, o ensino de linguagens e códigos específicos de comunicação e sinalização e tecnologia assistiva", assim como o "planejamento e produção de materiais pedagógicos acessíveis, considerando as necessidades específicas do estudante" (BRASIL, 2015, p. 99), de acordo com a Nota Técnica n55, de 2013. Toda a confecção e a aplicação dos procedimentos diferenciados deveriam ser executados pelos profissionais do Atendimento Educacional Especializado, porém, conforme relatado, não existe um profissional no AEE da escola da Asa Norte.

$\mathrm{Na}$ execução da atividade, em muitos momentos, o professor Antônio pegou a mão do aluno para auxiliá-lo na produção da atividade. Em outra ocasião, após insistência e não conseguir que o estudante realizasse a tarefa, o professor estipulou para o aluno, como forma corretiva, não trabalhar com o tablet naquele dia. Esse tipo de punição desestimula o estudante e afeta seu desempenho. O que poderia ser realizado para que o aluno conseguisse realizar a tarefa era acalmá-lo, apresentar a atividade de outra forma, como por meio de um jogo, depois tentar novamente realizá-la em folha. A punição ou a correção, quando não explicada ao aluno do porquê de estar ocorrendo, não gera resultados satisfatórios.

Concordando com Lunardi (2006, p. 7), “todos os elementos que compõem o currículo nas Séries Iniciais evidenciaram, [...] uma prática curricular que privilegia o ensino com conteúdos sem significado para os alunos, através de práticas centradas na exercitação e fixação". A matéria descontextualizada e apresentada em folha ao estudante com autismo o desestimula a realizar os exercícios e desenvolver a sua aprendizagem acerca daquele tema. A desvinculação dos conteúdos às atividades diárias de qualquer estudante não corrobora para que ele desenvolva uma aprendizagem significativa e possa posteriormente aplicar o aprendido em outros espaços.

\footnotetext{
${ }^{4}$ Recursos e Serviços utilizados para facilitar a aprendizagem das pessoas com deficiência. Exemplo: lupa, prancha de comunicação e softwares, entre outros.
} 
Foi possível observar que a relação entre os estudantes no interior de sala de aula é respeitosa, apesar de algumas vezes ocorrerem pequenas desavenças, como em quase toda sala de aula. Os estudantes, na maior parte do tempo, respeitam as regras do professor Antônio enquanto ele está dentro de sala de aula, mas, assim que ele precisa se ausentar, os alunos tendem a levantar de seus lugares, conversarem (muitas vezes em voz alta, chegando a deixar o aluno com autismo agitado) e brincarem de lançar bolinha de papel.

Na hora do intervalo, é observado que o aluno com autismo sempre vai para um mesmo banco no pátio. O docente Antônio relata que o estudante gosta daquele lugar. Em nenhum momento da observação do intervalo, foi identificada uma interação dos outros estudantes com o aluno Alisson. Esse distanciamento também é percebido em sala de aula. Os estudantes limitam-se aos cumprimentos diários de "olá, bom dia e tudo bem". De acordo com Sousa e Silva (2005, p. 15), existem "muitas dificuldades relacionadas à aceitação pelos colegas, ao entrosamento e ao relacionamento no grupo, ao preconceito, à rejeição e à discriminação". Essa falta de relação entre os estudantes gera um distanciamento entre eles e cria uma barreira, gerando, assim, uma exclusão velada do estudante com autismo. Por meio da sua dificuldade orgânica de interação e ausência de intervenção do professor Antônio em incentivar esse contato ocorre uma pseudoinclusão na sala de aula. Esse fator demonstra claramente que a escola e o professor estão despreparados para receber alunos com deficiência, principalmente os com autismo, que requerem uma proposta diferenciada de trabalho.

De acordo com Pimentel (2012, p. 140), existe nas salas de aula uma "figuração do estudante com deficiência na escola regular, sem que o mesmo esteja devidamente incluído no processo de aprender. Estar matriculado e frequentando a classe regular não significa estar envolvido no processo de aprendizagem daquele grupo". Essa colocação de Pimentel é pertinente e deve ser analisada com cuidado, porque, com a política de inclusão, todas as escolas devem incluir em suas salas de aulas regulares estudantes com deficiência. A questãomestre desse problema decorre, não somente de questões estruturais, mas da formação dos professores que trabalharão com esses estudantes. Muitos estão em sala de aula, recebem o aluno com deficiência, mas tratam o estudante apenas como um acessório em classe. Assim como qualquer outro estudante, o aluno com deficiência requer atenção às suas necessidades de aprendizagem. Concordando com Pimentel (2012, p. 141), é necessária "uma formação docente que envolva, para além do respeito, a compreensão da diversidade”. Se além da formação inicial e continuada, o docente não possuir uma postura de respeito e compreensão, não será possível realizar um trabalho inclusivo e perpetuar-se-á a exclusão velada. 
Outro momento em que é visível a presença da pseudoinclusão é no posicionamento dos estudantes em sala de aula. Todos os alunos ficam sentados em duplas, mas é relatado que o estudante Alisson sempre se senta com o seu monitor e nas carteiras ao fundo da sala. O local em que o aluno se senta em sala de aula demonstra que o professor está distante dele, pois prefere que ele tenha contato direto apenas com o Técnico de Assuntos Educacionais - Monitor. Esse distanciamento também comprova que o professor não quer que os outros estudantes façam dupla com o aluno, o que prejudica o seu contato com seus pares e dificulta, assim, a interação entre eles. Além disso, quando o estudante não se senta com seus colegas, não é possível que troquem conhecimentos, pois, em muitas situações, uma criança aprende observando o comportamento e a atitude da outra.

De acordo com Ferreira (2009, p. 28), “a limitação de oportunidades para desenvolver autonomia cria gradualmente prejuízos sociais e de aprendizagem para a vida desta criança, porque a torna cada vez mais dependente". Essa colocação corrobora claramente com o que ocorrerá com o estudante Alisson, caso a discriminação velada continue a ocorrer. O aluno não conseguirá desenvolver as suas potencialidades e haverá sempre uma dependência em executar atividades diárias por não ter sido estimulado. Concordando com Orrú (2012, p. 198), "para que o [aluno] seja um sujeito ativo de sua aprendizagem, é necessário que faça parte do grupo, que se relacione, que participe e compartilhe de todas as atividades desenvolvidas". Assim, caso isso não ocorra, a sua aprendizagem e seu desenvolvimento serão prejudicados em todas as áreas: cognitiva, afetiva e social.

Em consonância com o pensamento de Lunardi (2006, p. 13), "no contexto da sala de aula, esses alunos [são] completamente invisíveis para os professores. Não [há] esforço para possibilitar-lhes aprendizagens, porque em função do seu diagnóstico declarado, os professores se [veem] autorizados a não investir neles". De fato, essa invisibilidade ocorre com o estudante Alisson, a partir do momento em que o professor o deixa excluído do restante da turma e por não tratar a sua aprendizagem tão significativa quanto a do restante da classe.

\subsection{Os estudantes}

O professor Antônio possui em sua classe 17 alunos. Apenas nove crianças entregaram a autorização para participar do grupo focal. No dia do grupo, as crianças já chegaram à escola bastante agitadas. $\mathrm{O}$ docente solicitou que o grupo focal com as crianças 
fosse realizado antes que o aluno autista chegasse à escola. Não foi apresentado pelo docente nenhum motivo específico para que o estudante não participasse da discussão. As demais crianças que não entregaram a autorização foram para o pátio desenvolver uma atividade de matemática com o professor. Por meio do pedido do professor Antônio, ficou subentendido que ele não gostaria que o aluno com autismo participasse do grupo focal com as crianças. Essa atitude também é uma forma de exclusão do estudante das demais atividades que os outros desenvolvem. De acordo com Ferreira (2009, p. 33), ao apresentar alguns artigos da Convenção dos Direitos da Criança - CDC, ele escreve que

Artigo 12 - Aos Estados partes cabe assegurar à criança o direito de exprimir suas opiniões livremente, levando-se em conta sua idade e maturidade. Será dada à criança a oportunidade de ser ouvida em qualquer procedimento judicial e administrativo que lhe diga respeito em conformidade com as regras processuais do direito nacional (FERREIRA, 2009, p. 33).

Por meio desse artigo, fica assegurado à criança o direito de exprimir a sua opinião acerca de determinado tema ou assunto, caso essa seja a sua vontade. Esse direito não foi assegurado ao estudante Alisson na turma do professor Antônio. A partir do momento que ele pediu que a execução do grupo focal ocorresse antes que o aluno chegasse à sala, ele suprimiu o direito de ele participar. Uma das hipóteses para que isso tenha ocorrido é o receio de o aluno relatar alguma situação que o professor não estivesse preparado para explicar em relação às situações que ocorrem em sala de aula.

O grupo focal com as crianças foi iniciado com a leitura da revistinha da Turma da Mônica (Anexo V) referente à Inclusão Social. Os estudantes estavam bastante agitados e foi difícil conseguir obter um diálogo com as crianças acerca dos temas que seriam tratados naquele espaço. Essa dispersão das crianças representou, em parte, reflexo do trabalho do professor Antônio em sala de aula durante as observações e durante o ano. O docente não conseguiu que os alunos respeitassem momentos de diálogos com outras pessoas.

Com bastante dificuldade, foi possível identificar que os estudantes entenderam que inclusão é quando todas as pessoas fazem parte da sociedade, sem preconceito e discriminação: "Inclusão é a pessoa fazer parte da sociedade" (Amanda, 2015); "Não ter preconceito" (Ângelo, 2015) e "Sem preconceito com pessoas gordas, altas, baixas, negras, brancas ou com quem quer que seja" (Amauri, 2015). Por intermédio dessas falas, foi possível verificar que, apesar de não conseguirem aprofundar conceito, as crianças conseguem, após a história, identificar que a inclusão modifica toda a sociedade e que todos fazem parte desse processo inclusivo. 
Outro ponto que foi possível identificar é que elas conseguem visualizar situações de exclusão sérias dentro da própria escola. Os estudantes relatam um episódio ocorrido na Escola Parque com o estudante com autismo de sua classe. Eles expuseram que a criança começou a chorar em sala de aula e o professor gritou com o estudante e o expulsou de sala. As crianças informaram que, somente após esse episódio, o professor soube que a criança era autista: "Uma vez, na Escola Parque, o Alisson estava chorando muito na aula de música e a professora gritou com ele no microfone o expulsando de sala. Somente depois que ela o retirou de sala que soube que ele era especial" (Artur, 2015). A fala do estudante demonstra uma total falta de diálogo entre a escola da Asa Norte e a Escola Parque. De acordo com Fleuri (2009), a fragmentação entre os espaços de ensino e a falta de articulação entre eles dificulta o acolhimento e o tratamento das pessoas com deficiência. Sendo assim, nesse caso, não houve um trabalho de colaboração e troca entre as escolas, principalmente em informar que eles estariam recebendo um estudante com autismo que necessitaria de atendimento diferenciado. Esta carência de diálogo dificulta e prejudica o aprendizado do aluno, além de comprovar que escolas e professores não estão preparados para receberem estudantes em situação de inclusão.

Outra situação de exclusão está relacionada à própria postura dos estudantes da sala de aula do professor Antônio em relação ao estudante Alisson. Alguns discentes relataram que muitos dos meninos ficam imitando quando o estudante chora ou está realizando comportamentos estereotipados: "Foi igual ontem quando o Alberto e o Alfredo ficaram imitando quando o Alisson estava chorando. Esta não é uma atitude certa, isto é preconceito" (Ângelo, 2015). Essa atitude dos estudantes reflete diretamente no ofício do docente Antônio, porque é papel do professor repreender esses comportamentos e realizar um trabalho de conscientização a respeito da diversidade presente em sala de aula. Assim, fica visível que esse trabalho não foi realizado pelo professor durante o ano com a turma.

Foi relatada por um dos estudantes uma situação de solidariedade que ocorre durante o intervalo, quando os próprios estudantes cuidam do aluno Alisson para que outras crianças não batam nele durante o intervalo: "Ficavam duas pessoas na hora do recreio cuidando das crianças especiais. Às vezes o monitor não vinha para ficar olhando o Alisson no recreio, com isso o Tio pedia para que ficássemos com ele para as outras crianças não baterem nele" (Artur, 2015). Os estudantes demonstram que, apesar de não ser uma situação corriqueira, elas têm um cuidado diferenciado para que os outros alunos não agridam o estudante que tem autismo. Foi pedido que as crianças desenhassem ou escrevesse a respeito da inclusão. 

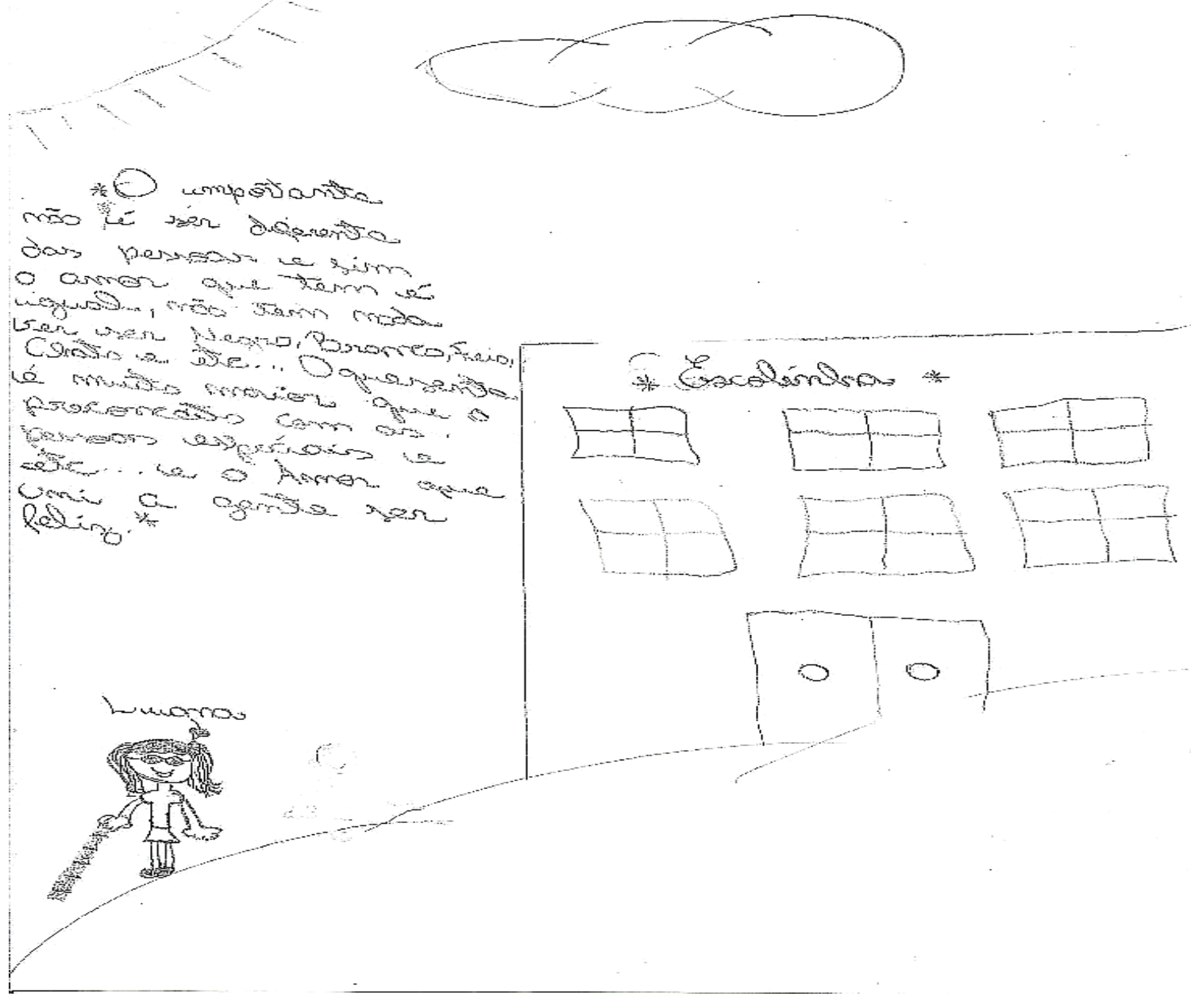

Figura 6 - Amanda

A aluna compreende que não deve existir preconceito de nenhum tipo, pois nós todos somos iguais. Apesar de o texto conter muitos erros ortográficos, a mensagem de que o mais importante é o amor retrata que não importa a deficiência, a diferença física entre os seres humanos, o mais importante é o amor que deve existir entrar eles. Quando a estudante escreve amor, podemos entender com solidariedade, empatia, inclusão. A escola nesse desenho retrata uma vitória para a criança com deficiência, pois é nesse espaço que ela se sentirá incluída e amada. 


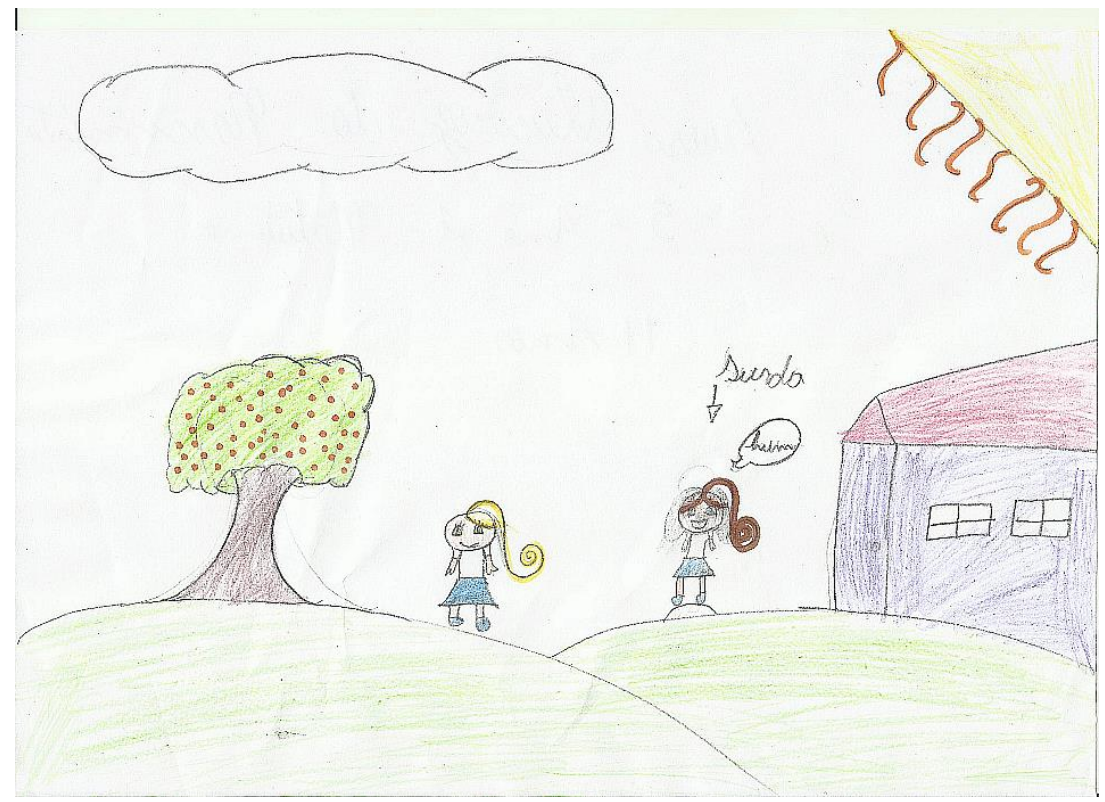

Figura 7 - Aline

Nesse desenho, são apresentadas duas crianças: uma sem deficiência (aparentemente) e outra com deficiência auditiva. Aline, ao escrever a palavra surda em cima da criança, deixa evidente que quer que todos entendam que a criança tem uma deficiência. Um detalhe interessante é que a aluna desenhou a personagem surda em cima de uma pedra, então fica subentendido que ela está buscando uma interação com a outra personagem que está um pouco distante e está tentando chamar a sua atenção. 


\section{CONSIDERAÇÕES FINAIS}

De acordo com a Declaração de Salamanca (1994), a escolarização de estudantes com deficiência deveria ocorrer em classes regulares, onde fossem disponibilizados ao aluno todas as condições de acesso e permanência ao ambiente escolar. O que foi observado é a falta de preparo das escolas em receber a diversidade de alunos, seja pela falta de adequação arquitetônica, espacial seja pela carência comunicacional e atitudinal.

A escola de Ceilândia tentou realizar adaptações arquitetônicas e espaciais em sua estrutura, por meio da instalação de pisos táteis e da construção de algumas rampas. Contudo essas adaptações não chegaram até a quadra de esportes, a qual é utilizada também pelos estudantes com deficiência. Foi identificado que os servidores da escola tratam todos com respeito e não foi possível saber se houve uma formação prévia para essas pessoas.

A escola da Asa Norte, apesar de ser considerada uma escola modelo na inclusão de estudantes com autismo, não está adequada para receber nenhuma outra deficiência, pois não existem pisos táteis na escola e a única adaptação encontrada é a dos banheiros. A acessibilidade atitudinal não ficou visível. A impressão que fica da escola é que nem o professor da sala observada, nem os outros servidores estão preparados para a inclusão. A postura do professor em sala e o seu tratamento diferenciado para com o aluno com autismo demonstra que ele ainda está na época da integração, quando o aluno era apenas inserido em sala de aula, sem que ocorresse uma mudança de atitude e postura do professor para que ele fizesse parte da turma. A falta de interesse da escola para com as necessidades do aluno também corrobora para esse fato. Essa ausência de interesse é explícita pelo fato de a escola não priorizar o atendimento especializado para os estudantes que necessitam disso.

$\mathrm{O}$ atendimento educacional especializado contemplado pela Constituição Federal de 1988 é bem observado pela escola de Ceilândia. Nela os estudantes que necessitam desse atendimento são acompanhados pela sala de recursos, pela Pedagoga e pela Psicóloga. Essa escola é diferenciada por apresentar uma sala de recursos específica para altas habilidades, o que não é muito usual nas demais unidades escolares. A escola da Asa Norte não observa esse artigo da CF de 1988 nem a LDB de 1996 que estabelece que "haverá, quando necessário, serviços de apoio especializado, na escola regular, para atender as peculiaridades da clientela de educação especial" (BRASIL, 2013, p. 124). Desse modo, ao não observar e compreender a importância do serviço especializado, a escola deixa o aluno que necessita sem o 
atendimento de que precisa, porque seus dirigentes consideram os cargos de direção mais importantes que a aprendizagem e o desenvolvimento dos seus estudantes.

De acordo com o Decreto Legislativo a respeito do direito da pessoa com deficiência $n^{\circ} 186 / 2008$, é preciso “combater os estereótipos, preconceitos e práticas nocivas em relação à pessoa com deficiência, inclusive aquelas relacionadas ao sexo e idade, em todas as áreas da vida" (BRASIL, 2013, p. 30). À luz da legislação, todas as escolas devem combater esse tipo de discriminação que é tão nociva ao desenvolvimento dos estudantes. Nas escolas analisadas, fica evidente que ainda existem muitas crianças preconceituosas, que reproduzem o que é vivenciado no interior de suas casas. O professor Carlos, da escola de Ceilândia, tenta combater isso de todos os modos, para que essa atitude não ocorra em sua sala de aula nem diante de seus olhos no interior da escola. Diferente dessa atitude, na Asa Norte, não é realizado nenhum trabalho pelo professor Antônio para combater essa forma de discriminação. As crianças de sua turma, por intermédio do grupo focal, relatam que é frequente que algumas crianças da sala de aula possuem essa postura de bullying para com os estudantes com deficiência.

Conforme apresentado pela Lei de Diretrizes e Bases da Educação, é exigido que o professor de turmas inclusivas possua um curso de especialização nessa área do conhecimento (BRASIL, 2013). Essa determinação é cumprida na escola de Ceilândia, mas não é observada na escola da Asa Norte, visto que o professor Antônio não possui nenhuma especialização, apenas está cursando uma segunda graduação desconexa à sua área de atuação com estudantes com deficiência. É necessário lembrar que o professor trabalha com um estudante com autismo clássico e alguns outros transtornos que não estão no quadro de deficiências. Desse modo, seria extremamente válido que a Secretaria de Educação, juntamente com a direção da escola, verificasse a necessidade de esse docente realizar cursos de aperfeiçoamento e especialização. A SEDF oferece vários cursos na EAPE acerca do tema e possui parcerias e programas de incentivo, para que o professor se especialize, contudo esse professor ainda não foi estimulado a realizar a sua formação continuada na área.

A Lei Brasileira de Inclusão - LBI (2015), em seu artigo 28, inciso III, deixa evidente que deve estar explícito no Projeto Político Pedagógico das escolas o atendimento educacional especializado. Esse artigo ainda não está sendo cumprido pela escola de Ceilândia, mas como a lei entra em vigor em 2016, neste ano a escola já deve deixar claro esse atendimento em seu PPP. Na Asa Norte, existe uma citação a respeito da sala de recursos e do atendimento especializado, mas, por falta de pessoal especializado, esse artigo é apenas uma teoria, não sendo cumprido na prática. 
Conforme o Currículo em Movimento da Educação Básica: Educação Especial (2014), a sala de aula regular deve ser o espaço real de inclusão. Por intermédio das observações de campo, foi possível identificar que a sala de aula da Asa Norte ainda não conseguiu compreender esse conceito. Nesse espaço ainda existe uma exclusão velada ou pseudoinclusão do aluno com autismo, por meio do posicionamento de sua carteira ao fundo da sala de aula, pela falta de troca entre o estudante e seus pares, quando ele fica condicionado ao diálogo somente com o Monitor que o acompanha.

A pseudoinclusão ou a exclusão velada prejudica o estudante que está na inclusão, pois o desmotiva a crescer e aprender junto com os demais estudantes da turma. $\mathrm{O}$ aluno torna-se apenas mais um dentro da sala de aula e o professor o esquece e faz da sua presença naquele espaço apenas como acessória.

Em 2009, foi criado o cargo de Monitor na Secretaria de Educação, quando foi instituída a função de Técnicos de Assuntos Educacionais - Monitor. Esse cargo é amparado pela Lei no 5106, de 2013 e pela portaria número 38, de 2013. Fica expresso nesses documentos que as atribuições do Monitor são de "suporte operacional às atividades de cuidado, higiene e estímulo de crianças no âmbito de competência da Secretaria de Estado de Educação" (GDF, 2013, p. 2). Esse detalhamento de funções gera uma grande falha na legislação, pois não deixa evidente, de fato, qual o papel do Monitor em sala de aula.

Conforme o que é apresentado na legislação, o Monitor fica sujeito apenas à função de cuidado do estudante, para que ele não se machuque e/ou machuque os outros, sendo responsável por sua higiene e seu estímulo. O que gera a brecha na legislação é a palavra estímulo, pois não fica evidente em quais situações e como ele ocorrerá. De acordo com o dicionário Michaelis online, estímulo é um incentivo, um reflexo condicionado (2016), isso manifesta que o papel do monitor no estímulo do aluno está apenas em proferir palavras de autoestima, de superação e autoconfiança; não ficando a cargo desse profissional qualquer atividade que tenha objetivos pedagógicos. Dessa forma, os Monitores ficam sujeitos a serem apenas acompanhantes do aluno em sala de aula, não podendo desenvolver com eles nenhuma atividade de cunho pedagógico. Sendo assim, o que o professor Antônio, da Asa Norte, relata, em sua entrevista e durante a observação, que o Monitor acompanha, de fato, o estudante com autismo em todas as suas atividades em sala de aula, apenas incentivando-o a realizá-las.

É preciso esclarecer que o Monitor não é um professor Bidocente. Desse modo, não é sua atribuição o ensino do aluno nem o acompanhamento de sua aprendizagem, devendo esta ficar a cargo do professor de sala ou do bidocente. 
O documento Saberes e Práticas da Inclusão do MEC (2006) apresenta algumas intensidades de apoio que podem ser ofertadas aos estudantes com deficiências, sendo elas: Iminentes, Limitado, Extensivo e Pervasivo. Foi observado nas escolas que as que ocorrem com mais frequência em seu interior são as Iminentes, as Extensivas e as Pervasivas. O apoio Iminente, por ser transitório, é verificado no apoio do professor ou Monitor ao aluno nos momentos de crise ou em alguma situação específica. O apoio Extensivo ocorre de modo regular em um ambiente específico e ele é observado com clareza nas salas de recurso generalistas e específicas da escola de Ceilândia e por meio do atendimento da Pedagoga aos estudantes. O Pervasivo é observado, mas não ocorre no interior das escolas, mas, sim, por meio do acompanhamento de médicos, fonoaudiólogos, psicólogos e fisioterapeutas.

A Educação Inclusiva ainda necessita de muitos estudos e investigações para ocorrer de fato em todas as escolas brasileiras. Dessa forma, este trabalho possibilitou a abertura de caminhos que ainda não estavam sendo percorridos na educação do Distrito Federal. O debate acerca da inclusão e a sua ligação com a formação inicial na Universidade de Brasília ainda não havia sido explorada por outros autores. Diante disso, esse trabalho possibilita a abertura para uma série de diálogos que necessitam estar presentes nas unidades escolares: como ocorre a inclusão de nossos alunos com deficiência, transtorno global do desenvolvimento e altas habilidades? Como podemos melhorar tal situação? Como adotar práticas diferenciadas para atender as necessidades individuais de nossos estudantes? Quais as mudanças necessárias na formação inicial que contribuem para o desenvolvimento profissional em salas de aula inclusivas? Esses são apenas alguns questionamentos que ainda não puderam ser respondidos apenas com esse trabalho e merecem novas pesquisas para encontrar respostas.

Percebemos que hoje, apesar de o Currículo em Movimento da Educação Básica de 2014 atestar que todas as escolas públicas são inclusivas, percebemos que o que ocorre não é a inclusão, e sim a integração. Não devemos nem podemos colocar a "culpa" nos professores, mas em todas as instituições de ensino que não oferecem suporte para que todos os estudantes sejam atendidos em suas especificidades e não apenas aqueles que possuem alguma deficiência.

A formação inicial ofertada pela Universidade de Brasília é deficitária, mas outras universidades pelo Brasil também apresentam o mesmo problema, de acordo com estudos apresentados por Martins (2012) e Góes (2013). Assim, medidas advindas do Ministério da Educação devem ser elaboradas para uma reestruturação das disciplinas ofertadas, da apresentação de um número mínimo de conteúdos a serem trabalhados, e um maior percentual 
de atividades práticas que permitam ao estudante vivenciar na prática o debatido em sala de aula.

A prática pedagógica do Pedagogo formado na Universidade de Brasília em classes inclusivas não ocorre de forma semelhante. Cada profissional tem sua forma de trabalho, não fazendo que seja a formação recebida na universidade um diferencial em seu trabalho. Conforme observado, o professor da Asa Norte recebeu a mesma formação inicial do professor de Ceilândia, mas ambos os docentes lidam com a diversidade em sala de aula de formas distintas. O primeiro até mesmo executando uma pseudoinclusão em sua sala de aula.

O que ficou notório é que o empenho e a dedicação em construir novos conhecimentos, por meio da formação continuada, ocorrem com a identificação, na prática, de situações de um possível despreparo do docente. Por meio dessa necessidade, a busca e o incentivo por formação continuada determinam a diferença na forma de trabalho dos professores que estão em sala de aula.

A proposta do Projeto Acadêmico do curso de Pedagogia ainda não consegue atender as necessidades de formação inicial de qualidade de todos os estudantes, pois esquecem-se, em muitos momentos, que a prática deve estar ligada à teoria em todas as disciplinas e nos projetos do curso. Esse deficit de formação prática permite que o estudante seja formado apenas teoricamente em seu curso. Conforme observado e constatado, são poucos e insuficientes os momentos de prática presentes no curso de Pedagogia.

As disciplinas "O Educando com Necessidades Educacionais Especiais" e "Aprendizagem e desenvolvimento do PNEE" apresentam ementas que apenas contextualizam a deficiência de uma forma geral, assim como as suas formas de aprendizagem. Foi observado que existe uma lacuna a ser preenchida no curso de formação inicial, onde deveria ser discutida a inclusão em sala de aula e como executar as práticas diferenciadas para atender a todos os estudantes.

As práticas pedagógicas observadas em sala de aula são significativas, principalmente as empregadas na sala de aula de Ceilândia, porque, por meio delas, os estudantes vão percebendo e compreendendo que, em todos os espaços, existe a diversidade e que ela deve ser respeitada. Além disso, eles compreendem que o potencial de cada um deve ser estimulado, não permitindo que existam discriminações e preconceitos.

O grupo focal com as crianças foi significativo, pois, por intermédio dele, foi possível depreender que, apesar de elas não terem domínio da palavra inclusão, elas conseguem visualizar situações onde a inclusão ocorre ou não. Em muitos momentos, ficou 
evidente a exclusão, mas também foi identificada, pelos próprios estudantes, a necessidade de compreender o outro da forma como é ele.

Diante disso, entende-se que é necessário que ocorra uma mudança significativa no curso de Pedagogia da Universidade de Brasília, sendo diminuído o quantitativo de disciplinas optativas. Essa diminuição é relevante para que sejam incorporadas a disciplinas obrigatórias algumas que hoje são optativas, mas que são essenciais para a formação do futuro Pedagogo, como: educação infantil, educação de jovens e adultos, avaliação escolar e a incorporação da disciplina educação inclusiva. Essa mudança estrutural é significativa para o Pedagogo que está sendo formado para atuar na docência, que é o principal objetivo do curso (UnB 2002). A elaboração de um novo Projeto Acadêmico de Curso é a solução encontrada para a reestruturação do curso de Pedagogia, que também necessita incorporar em suas disciplinas mais momentos de prática.

Por meio da elaboração deste trabalho, foi possível compreender que apenas a formação inicial ofertada pela Universidade não é capaz de suprir todas as necessidades de formação indispensáveis para a atuação em sala de aula. Desse modo, a formação continuada é essencial para suprir os questionamentos e as dúvidas que surgem ao longo do trabalho docente em sala de aula. É fundamental que as instituições de ensino incentivem o professor que está em classe a realizar cursos de capacitação, aperfeiçoamento e especializações. A divulgação dos cursos ofertados pela EAPE, a todo semestre, no interior das escolas também é importante para que o professor se atualize a cada semestre.

Por todo o exposto, conclui-se que muitas discussões ainda precisam ser realizadas acerca do tema de formação de professores para a inclusão. Apenas essa dissertação não consegue suprir a necessidade de informações, dados e mudanças que necessitam ser realizadas na educação brasileira, para que a inclusão ocorra plenamente em todas as escolas. 


\section{REFERENCIAS}

AINSCOW, M. Tornar a educação inclusiva: como esta tarefa deve ser conceituada? In: FÁVERO, O., et al. Tornar a educação inclusiva. Brasília: UNESCO, 2009. Cap. 1, p. 1123.

ALVES, F. Inclusão: muitos olhares, vários caminhos e um grande desafio. 5.ed. Rio de Janeiro: Wak Editora, 2012.

ANDRÉ, M. E. D. A. D. Etnografia da prática escolar. 15ª edição. ed. Campinas: Papirus, 2008.

ARMAZÉM, C. M. Lei Ordinária nº. CM 0004/2015. Câmara Armazém, 2015. Disponivel em: <http://www.camaraarmazem.sc.gov.br/softcam/proposicao_print_pdf.php?item=28>. Acesso em: 05 janeiro 2016.

BEYER, H. O. Inclusão e avaliação na escola: de alunos com necessidades. Porto Alegre: Mediação, 2005.

BRASIL. Legislação brasileira sobre pessoas com deficiência. $7^{\mathrm{a}}$. ed. Brasília: Câmara dos Deputados, 2013.

Orientações para implementação da Política de Educação Especial na perspectiva da Educação Inclusiva, Brasília, 2015. Disponivel em: $<$ http://portal.mec.gov.br/index.php?option=com_docman\&view=download\&alias=17237secadi-documento-subsidiario-2015\&Itemid=30192 > . Acesso em: 10 Dezembro 2015.

Plano Nacional de Educação 2014- 2024: Lei no 13.005 , de junho de 2014, que aprova o Plano Nacional de Educaão (PNE) e dá outras providências. Brasília: Edições Câmara, 2014.

2001.

Diretrizes nacionais para a educação especial na educação básica. MEC; SEESP,

Parecer CNE/CP n9/2001 - Diretrizes Curriculares Nacionais para a Formação de Professores da Educação. Ministério da Educação. DF, p. 70. 2001.

. Lei no 9394, de 20 de dezembro de 1996. In: DEPUTADOS, C. D. Legislação sobre Pessoas com Deficiência. 7.ed. ed. Brasília: Edições Cãmara, 2013. p. 124-125.

DECRETO No 5.296 DE 2 DE DEZEMBRO DE 2004. Planalto, 2015. Disponivel em: <http://www.planalto.gov.br/ccivil_03/_ato2004-2006/2004/decreto/d5296.htm>. Acesso em: 06 Janeiro 2016.

. LEI N ${ }^{\circ}$ 9.394, DE 20 DE DEZEMBRO DE 1996. Planalto, 2016. Disponivel em: <http://www.planalto.gov.br/ccivil_03/Leis/L9394.htm>. Acesso em: 17 fevereiro 2016.

Lei Brasileira de Inclusão da pessoa com deficiência: lei no 13146 , de 6 de julho de 2015. Edições Câmara. ed. Brasília: Câmara dos Deputados, 2015.

BRASÍLIA, U. D. Cursos de Graduação. Disponivel em: <http://fce.unb.br/graduacao〉. Acesso em: 16 Novembro 2014. 
CAMARGO, R. G.; SARZI, L. Z. INCLUSÃO E INTERAÇÃO: PESQUISA SOBRE ATUAÇÃO DO PROFESSOR DE EDUCAÇÃO ESPECIAL EM BIDOCÊNCIA. Revista Educere Et Educare, v. Vol. 7, p. 103- 123, 2012. ISSN ISSN 1981-4712.

CARNEIRO, M. S. C. Adultos com síndrome de down. Campinas: Papirus, 2008.

CAVALLEIRO, E. D. S. Considerações sobre a etnografia na escola e prática investigativa sobre as relações raciais e de gênero. In: WELLER, W.; PFAFF, N. Metodologia da pesquisa qualitativa em Educação. Petrópolis, RJ: Vozes, 2013. p. 271-278.

CEILÂNDIA, A. R. D. Conheça a Ceilância RA IX. Disponivel em:

<http://www.ceilandia.df.gov.br/sobre-a-ra-ix/conheca-ceilandia-ra-ix.html>. Acesso em: 16 Novembro 2014.

CNE, C. N. D. E. Diretrizes Curriculares Nacionais para o Curso de Pedagogia, 2005. Disponivel em: <http://portal.mec.gov.br/cne/arquivos/pdf/pcp05_05.pdf >. Acesso em: 12 Novembro 2015.

Reexame do Parecer CNE/CP n ${ }^{\circ}$ 5/2005, que trata das Diretrizes Curriculares Nacionais para o Curso de Pedagogia, 2006. Disponivel em:

<http://portal.mec.gov.br/cne/arquivos/pdf/pcp003_06.pdf>. Acesso em: 12 Novembro 2015.

RESOLUÇÃO CNE/CP N 1, DE 15 DE MAIO DE 2006. MEC- Ministério da

Educação, 2015. Disponivel em: <http://portal.mec.gov.br/cne/arquivos/pdf/rcp01_06.pdf>. Acesso em: 12 Novembro 2015.

. Resolução nº 2, de $1^{\text {o }}$ de julho de 2015. MEC- Ministério da Educação, 2015.

Disponivel em:

$<$ http://portal.mec.gov.br/index.php?option=com_docman\&view=download\&alias=17719-

res-cne-cp-002-03072015\&category_slug=julho-2015-pdf\&Itemid=30192 > . Acesso em: 06 Janeiro 2016.

CROCHÍK, J. L. Educação inclusiva e preconceito: desafios para a prática pedagógica. In: MIRANDA, T.; FILHO, T. A. G. O professor e a educação inclusiva. Salvador: EDUFBA, 2012. p. 39-60.

CUNHA, C. M. D.; SIEBERT, E. C. Bidocência: Inclusão ou Exclusão dos alunos com necessidades especiais? IX Congresso Nacional de Educação - EDUCERE E III Encontro Sul brasileiro de Psicopedagogia, Paraná, 26 a 29 outubro 2009. 2152- 2159.

DEPUTADOS, C. D. LDB: Lei de Diretrizes e Bases da Educação Nacional. 11ª . ed. Brasília: Edições Câmara, 2015.

FE, F. D. E. I encontro da comunidade da faculdade de educação da unb: ressignificando o projeto acadêmico do curso de pedagogia. Brasília, p. 59, 2011. Disponivel em: $<$ http://www.fe.unb.br/images/graduacao/reformulacao-curriculo/relatorio-1.pdf >. Acesso em: 6 Janeiro 2015.

Faculdade de Educação. Disponivel em:

<http://www.fe.unb.br/images/graduacao/reformulacao-curriculo/mudanca-curricular-fe.pdf >. Acesso em: 6 Janeiro 2015. 
FERREIRA, J. R. Financiamento da educação básica: o público e o privado na educação especial brasileira. In: FÁVERO, O., et al. Tornar a educação inclusiva. Brasília: UNESCO, 2012. p. 55-64.

FERREIRA, M. C. C.; FERREIRA, J. R. Sobre inclusão, políticas públicas e práticas pedagógicas. In: GÓES, M. C. R. D.; LAPLANE, A. L. F. D. Políticas e Práticas de Educação Inclusiva. $4^{\text {a }}$. ed. Campinas: Autores Associados, 2013. p. 21-46.

FERREIRA, W. B. Entendendo a discriminação contra estudantes com deficiência na escola. In: FÁVERO, O., et al. Tornar a educação inclusiva. Brasília: UNESCO, 2009. p. 25-54.

FLEITH, D. D. S. Mitos e fatos sobre os superdotados. In: FÁVERO, O., et al. Tornar a educação inclusiva. Brasília: UNESCO, 2009. p. 199-212.

FLEURI, R. M. Complexidade e interculturalidade: desafios emergentes para a formação de educadores em processos inclusivos. In: FÁVERO, O., et al. Tornar a educação inclusiva. Brasília: UNESCO, 2009. p. 65-88.

FONTANA, R. A. C.; FURGERI, D. K. P.; PASSOS, L. V. L. Cenas cotidianas de inclusão: sentidos em jogo. In: GÓES, M. C. R. D.; LAPLANE, A. L. F. D. Políticas e Práticas de Educação Inclusiva. 4 ${ }^{\text {}}$. ed. Campinas: Autores Associados, 2013. p. 139-153.

GATTI, B.; ANDRÉ, M. A relevância dos métodos de pesquisa qualitativa em Educação no Brasil. In: WELLER, W.; PFAFF, N. Metodologias da Pesquisa Qualitativa em Educação: Teoria e Prática. $3^{\text {a }}$ Edição. ed. Petrópolis, RJ: Vozes, 2013. p. 29-38.

GDF. Currículo em movimento da educação básica: pressupostos teóricos. Brasília: [s.n.], 2014.

Conheça Brasília RA I. Disponivel em: <http://www.brasilia.df.gov.br/sobre-a-rai/conheca-brasilia-ra-i.html>. Acesso em: 16 Novembro 2014.

Orientação Pedagógica: Educação Especial. Brasília, 2010.

LEI Nº 5.106, DE 3 DE MAIO DE 2013. Brasília, 2013.

PORTARIA Nº 38, DE 7 DE FEVEREIRO DE 2013. Brasília, 2013.

Orientação Pedagógica: Projeto Político- Pedagógico e coordenação Pedagógica nas escolas. Brasília, 2014.

2014.

Currículo em Movimento da Educação Básica: Educação Especial. Brasília. v. 7,

GIL, A. C. Métodos e técnicas de pesquisa social. $4^{\text {a }}$ ed. São Paulo: Atlas, 1995.

GLAT, R.; PLETSCH, M. D. Inclusão Escolar de alunos com necessidades especiais. $2^{\mathrm{a}}$. ed. Rio de Janeiro: Eduerj, 2012.

GÓES, M. C. R. D. Desafios da inclusão de alunos especiais: a escolarização do aprendiz e sua constituição como pessoa. In: GÓES, M. C. R. D.; LAPLANE, A. L. F. D. Políticas e Práticas de Educação Inclusiva. $4^{\text {a }}$. ed. Campinas: Autores Associados, 2013. p. 65-84. 
GUARÁ, A. Apresentação Guará RA X. Disponivel em:

<http://www.guara.df.gov.br/sobre-a-secretaria/conheca-guara-ra-x.html>. Acesso em: 16 Novembro 2014.

Governo do Distrito Federal. Disponivel em:

<http://www.cre.se.df.gov.br/ascom/documentos/2013_Cad_End_CRE_Publica_GUAR\%C3 \%81.pdf $>$. Acesso em: 16 Novembro 2014.

IMBERNÓN, F. Formação Docente e Profissional: formar-se para a mudança e a incerteza. 6 ${ }^{\text {. }}$ ed. São Paulo: Cortez Editora, 2006.

KASSAR, M. D. C. M. Matrículas de crianças com necessidades educacionais especiais na rede de ensino regular: do que e de quem se fala? In: GÓES, M. C. R. D.; LAPLANE, A. L. F. D. Políticas e Práticas de Educação Inclusiva. Campinas: Autores Associados, 2013. p. 47-64.

LUNARDI, G. M. As práticas curriculares de sala de aula e a constituição das diferenças dos alunos no processo de ensino e aprendizagem. XXVIII Reunião anula da ANPEd, 2006. Disponivel em: <www.28reuniao.anped.org.br/textos/gt15/gt151363int.rtf>. Acesso em: 02 Março 2016.

MANTOAN, M. T. E. Inclusão escolar: o que é? por quê? como fazer? São Paulo: Moderna, 2003.

O direito de ser, sendo diferente, na escola. Brasília, 2004.

MARQUEZAN, R. O deficiente no discurso da legislação. Campinas: Papirus, 2009.

MARTINS, L. D. A. R. A visão de licenciados sobre a formação inicial com vistas à atuação com a diversidade dos alunos. In: CAIADO, K. R. M.; JESUS, D. M. D.; BAPTISTA, C. R. Professores e educação especial: formação em foco. Porto Alegre: Editora Mediação, v. 1, 2011. Cap. 3, p. 51-63.

Reflexões sobre a formação de professores com vistas à educação inclusiva. In:

MIRANDA, T. G.; FILHO, T. A. G. O professor e a educação inclusiva: formação, práticas e lugares. Salvador: EDUFBA, 2012. p. 25-38.

MEC, M. D. E. Saberes e práticas da Inclusão: dificuldades de comunicação e sinalização Deficiência física. Brasília, 2006.

Saberes e práticas da inclusão: recomendações para a construção de escolas inclusivas. Brasília, 2006.

Declaração Internacional de Montreal sobre Inclusão, 2015. Disponivel em: <http://portal.mec.gov.br/seesp/arquivos/pdf/dec_inclu.pdf〉. Acesso em: 10 Dezembro 2015.

Declaração de Salamanca: Sobre princípios, políticas e práticas na área das necessidades educativas especiais, 2015. Disponivel em:

<http://portal.mec.gov.br/seesp/arquivos/pdf/salamanca.pdf>. Acesso em: 10 Dezembro 2015.

Declaração dos Direitos das Pessoas Deficientes, 2015. Disponivel em:

<http://portal.mec.gov.br/seesp/arquivos/pdf/dec_def.pdf>. Acesso em: 10 Dezembro 2015. 
Carta para o Terceiro Milênio, 2015. Disponivel em:

<http://portal.mec.gov.br/seesp/arquivos/pdf/carta_milenio.pdf>. Acesso em: 10 Dezembro 2015 .

Convenção da Organização dos Estados Americanos, 2015. Disponivel em:

<http://portal.mec.gov.br/seesp/arquivos/pdf/guatemala.pdf >. Acesso em: 10 Dezembro 2015.

Instrumento de Avaliação de Cursos de Graduação. Instituto Nacional de Estudos e Pesquisas Educacionais Anísio Teixeira - INEP. Brasília. 2015.

MEC, M. D. E.; INEP, I. N. D. E. E. P. E. A. T. Instrumento de Avaliação de Cursos Superiores de Pedagogia (subsidia o ato de Reconhecimento, 2011. Disponivel em: <http://download.inep.gov.br/download/superior/condicoesdeensino/2010/instrumento_recon hecimento_curso_pedagogia2.pdf>. Acesso em: 6 Janeiro 2016.

MEC/SEESP. Política Nacional de Educação Especial na Perspectiva da Educação Inclusiva, 2007. Disponivel em:

$<$ http://portal.mec.gov.br/index.php?option=com_docman\&view=download\&alias=16690politica-nacional-de-educacao-especial-na-perspectiva-da-educacao-inclusiva05122014\&Itemid=30192> . Acesso em: 10 Dezembro 2015.

MEINERZ, C. B. Grupos de Discussão: uma opção metodológica na pesquisa em educação. Educação e Realidade, Porto Alegre, v. 36, p. 485-504, maio/ agosto 2011.

MICHAELIS. Michaelis. Michaelis UOL. Disponivel em:

$<$ http://michaelis.uol.com.br/moderno/portugues/index.php?lingua=portuguesportugues\&palavra=est\%EDmulo >. Acesso em: 16 fev. 2016.

MITTLER, P. Educação inclusiva: contextos sociais. Porto Alegre: Artmed, 2003.

OLIVEIRA, M. K. D. Vygotsky: Aprendizado e desenvolvimento um processo sóciohistórico. $4^{\text {a }}$. ed. São Paulo: Scipione, 1997.

ORRÚ, S. E. Trajetória, avanços e desafios na concepção e educação de educandos com autismo. In: ORRÚ, S. E. Estudantes com necessidades especiais: singularidades e desafios na prática pedagógica inclusiva. Rio de Janeiro: Wak editora, 2012. p. 177-204.

PADILHA, A. M. L. Práticas Pedagógicas na Educação Especial: a capacidade de significar o mundo e a inserção cultural do deficiente mental. $4^{\mathrm{a}}$. ed. Campinas: Autores Associados, 2007.

PÉREZ, S. G. P. B. O estudante com altas habilidades/ superdotação: o que é, o que não é e como vir a ser. In: ORRÚ, S. E. Estudantes com necessidades especiais: singularidades e desafios na prática pedagógica inclusiva. Rio de Janeiro: Wak Editora, 2012. p. 237-268.

PFAFF, N. Etnografia em contextos escolares: pressupostos gerais e experiências interculturais no Brasil e na Alemanha. In: WELLER, W.; PFAFF, N. Metodologia da pesquisa qualitativa em Educação. Petrópolis, RJ: Vozes, 2013. p. 254- 270.

PIMENTEL, S. C. Formação de professores para a inclusão: Saberes necessários e percuros formativos. In: MIRANDA, T. G.; FILHO, T. A. G. O professor e a educação inclusiva: formação, práticas e lugares. Salvador: EDUFBA, 2012. p. 139-155. 
PLETSCH, M. D. Repensando a inclusão escolar: diretrizes políticas, práticas curriculares e deficiência intelectual. Rio de Janeiro: NAU, 2010.

REPÚBLICA, P. Convenção sobre os Direitos das Pessoas com Deficiência: protocolo facultativo à Convenção sobre os direitos das pessoas com deficiência. Tradução de Tradução Oficial/ Brasil. Brasília: [s.n.], 2007.

SÁNCHEZ, P. A. A educação inclusiva na Espanha. In: FÁ VERO, O., et al. Tornar a educação inclusiva. Brasília: UNESCO, 2009. p. 89-103.

Educação inclusiva na Espanha. In: FÁVERO, O., et al. Tornar a educação inclusiva. Brasília: UNESCO, 2012. p. 89-104.

SEDF, S. D. E. E. D. D. F. Diretrizes de Avaliação Educacional: aprendizagem, instituicional e de larga escola 2014- 2016. Brasília, 2014.

SILVA, L.; CONRADO, R. M. Experiências e dinâmicas de inclusão: um olhar comprometido e afetivo. Rio de Janeiro: Wak Editora, 2013.

SOARES, M. A. L.; CARVALHO, M. D. F. O professor e o aluno com deficiência. São Paulo: Cortez Editora, 2012.

SOUSA, S. B.; SILVA, R. V. D. S. E. Inclusão escolar e a pessoa com deficiência nas aulas de educação física das redes municipal e estadual de uberlândia/mg, 2005. Disponivel em: <28reuniao.anped.org.br/textos/gt15/gt15280int.rtf>. Acesso em: 02 Março 2016.

STRAUSS, A.; CORBIN, J. Pesquisa Qualitativa: Técnicas e procedimentos para o desenvolvimento de teoria fundamentada. Tradução de Luciane de Oliveira Rocha. $2^{\text {a }}$ edição. ed. Porto Alegre: Artmed, 2008.

UNB, U. D. B. Projeto Acadêmico do Curso de Pedagogia. Brasília: Faculdade de Educação, 2002.

. Matrícula Web. Universidade de Brasilia, 2015. Disponivel em:

$<$ https://matriculaweb.unb.br/matriculaweb/graduacao/disciplina.aspx?cod=197947>. Acesso em: 06 Janeiro 2015.

. Matrícula Web. Universidade de Brasília, 2015. Disponivel em:

$<$ https://matriculaweb.unb.br/matriculaweb/graduacao/disciplina.aspx?cod=193283>. Acesso em: 06 Janeiro 2015.

Curso de pedagogia para professores em exercício. Disponivel em:

<http://www.lite.fe.unicamp.br/grupos/formac/proposta/unb.htm>. Acesso em: 17 janeiro 2016.

VEIGA, I. P. A. Professor: Tecnólogo do ensino ou agente social? In: VEIGA, I. P. A.; AMARAL, A. L. (. ). Formação de Professores: políticas e debates. Campinas: Papirus, 2002. p. 65-93.

Educação básica e educação superior: projeto político- pedagógico. $3^{\mathrm{a}}$. ed.

Campinas: Papirus, 2008. 
VILLAS BOAS, B. M. D. F. Virando a escola do avesso por meio da avaliação. Campinas: Papirus, 2008.

WELLER, W. Grupos de discussão na pesquisa com adolescentes e jovens: aportes teóricometodológicos e análise de uma experiência com o método. Educação e Pesquisa, São Paulo, p. 241-260, maio/agosto 2006.

WELLER, W.; PFAFF, N. Pesquisa qualitativa em educação: origens e desenvolvimentos. In: WELLER, W.; PFAFF, N. Metodologias da Pesquisa Qualitativa em Educação: Teoria e Prática. $3^{\text {a }}$ Edição. ed. 3. ed. Petrópolis, RJ: Vozes, 2013. p. 12-28. 


\section{Apêndice I - Questionário}

Universidade de Brasília - UnB

Faculdade de Educação - FE

Programa de Pós- Graduação em Educação - PPGE

Mestranda Thalita Andressa Barbosa Paes Landim

Orientadora Dr ${ }^{\mathrm{a}}$ Ilma Passos Alencastro Veiga

Este questionário faz parte dos instrumentos de pesquisa utilizados para a obtenção de dados a serem analisados na dissertação situada na linha de pesquisa: Profissão Docente, Currículo e Avaliação. Este questionário tem por objetivo traçar um perfil identidário dos profissionais que estão atuando na Educação Inclusiva. Em nenhuma hipótese, será divulgada a identidade dos sujeitos a serem entrevistados.

\section{Questionário}

\section{Identificação}

1- Nome:

2- Idade:

3- Sexo:

Formação Acadêmica

4- Instituição que cursou a Graduação:

( ) Pública

( ) Privada

5- Nome da Instituição:

6- Curso:

7- Localidade:

8- U.F:

9- País:

10- Modalidade:

( ) Presencial

( ) À distância

11- Ano de conclusão de curso:

12- Possui Especialização:
( ) $\mathrm{Sim}$
( ) Não

13- Nome da Instituição:

14- Nome da Especialização:

Atuação Profissional

15- Ano de ingresso na Secretaria de Educação:

16- Cargo/ Função:

17- Regional em que atua:

18-Regime de trabalho:

( ) Dedicação exclusiva

( ) $40 \mathrm{~h}$

( ) $20 \mathrm{~h}$

19- Série em que atua:

20- Atende alunos com deficiência? Se sim, quais deficiências atende? 


\section{Outras Questões}

21-Quando realizou o curso de Graduação teve disciplinas na área de educação especial? Quais?

22- Para você, o que é a deficiência?

23- O que é a inclusão?

24- O que é integração?

25- A sua formação inicial lhe deu suporte teórico e metodológico para trabalhar com alunos com deficiência?

26- Em qual momento da sua atuação profissional você sentiu necessidade de uma formação continuada para atuar com alunos em inclusão? 


\section{APÊNDICE II - TERMO DE CONSENTIMENTO CRIANÇAS}

Universidade de Brasília - UnB

Faculdade de Educação - FE

Programa de Pós- Graduação em Educação -

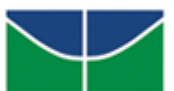

Universidade de Brasília

PPGE

Linha de pesquisa: Profissão Docente, Currículo e Avaliação.

TERMO DE CONSENTIMENTO LIVRE E ESCLARECIDO

MENORES DE 16 ANOS

Seu filho está sendo convidado (a) como voluntário (a) a participar do estudo "Formação do Pedagogo na UnB e a sua prática com a Educação Inclusiva" e que tem como objetivo compreender como o Pedagogo egresso do curso de Pedagogia da UnB desenvolve a sua prática pedagógica em escolas inclusivas nos anos iniciais do ensino fundamental. Acreditamos que ela seja importante porque existem poucos estudos na área de formação de professores para a inclusão.

\section{COMO OCORRERÁ À PARTICIPAÇÃO NO ESTUDO?}

A participação no referido estudo será através de um grupo focal com as crianças da turma. $\mathrm{O}$ grupo focal é uma espécie de entrevista em grupo, onde todos os participantes terão oportunidade de se expressar caso essa seja a sua vontade. Os estudantes também realizarão um desenho com o objetivo de expressarem o seu entendimento sobre o tema da pesquisa. $\mathrm{O}$ grupo focal e o desenho serão realizados no dia 20/08/2015, no período normal de aula e terá duração de 1 h a 1:30.

\section{SIGILO E PRIVACIDADE}

Estou ciente da privacidade de meu representado será respeitada, ou seja, seu nome ou qualquer outro dado ou elemento que possa, de qualquer forma, identificá-lo, será mantido em sigilo. A pesquisadora se responsabiliza pela guarda e confidencialidade dos dados, bem como a não exposição dos dados de pesquisa.

\section{CONTATO}

A pesquisadora envolvida com o referido projeto é mestranda Thalita Andressa Barbosa Paes Landim da Universidade de Brasília - UnB e poderei manter contato pelos telefones

ou pelo e-mail: thalitaandressa@gmail.com

\section{DECLARAÇÂO}

Declaro que li e entendi todas as informações presentes neste Termo de Consentimento Livre e Esclarecido. Enfim, tendo sido orientado quanto ao teor de todo o aqui mencionado e compreendido a natureza e o objetivo do já referido estudo, manifesto meu livre consentimento em meu filho participar da pesquisa.

\begin{tabular}{|r|r|}
\hline \multicolumn{2}{|l|}{ Dados do participante da pesquisa } \\
\hline Nome: & \\
\hline Idade: & \\
\hline
\end{tabular}

\begin{tabular}{|r|}
\hline Dados do responsável pelo participante da pesquisa \\
\hline Nome: \\
\hline Telefone: \\
\hline
\end{tabular}

Brasília, de agosto de 2015. 


\section{Apêndice III - Perguntas para a entrevista Semi - Estruturada}

\section{Entrevista Semi- Estruturada}

1- Este é o seu primeiro ano trabalhando com alunos que estão na inclusão?

2- Quando surgiu o interesse em trabalhar com crianças que estão na inclusão?

3- Quais as maiores dificuldades encontradas no trabalho com crianças com deficiência?

4- Existe um apoio, para o seu trabalho em sala, da direção da escola? A coordenação te fornece suporte com propostas de atividades diferenciadas para as crianças em inclusão?

5- A escola trabalha com adequação curricular para os alunos com deficiência?

6- O senhor percebe/ percebeu como as disciplinas cursadas na faculdade de educação sobre ensino especial possam ter influenciado na sua maneira de trabalhar com os alunos em inclusão?

7- Em que aspecto deve haver uma mudança nas disciplinas ofertadas pela FE?

8- Em qual momento o senhor sentiu a necessidade de realizar a pós- graduação? Existiu alguma motivação específica?

9- O senhor acredita que as escolas públicas do DF estão preparadas para receberem crianças com deficiência ou altas habilidades? Existe adequação física, espacial e pedagógica?

10- Para o senhor, qual a postura que um professor inclusivo deve ter?

11-O senhor já se deparou realizando alguma estratégia de inclusão inadequada, e depois verificou que aquele procedimento não condizia com a proposta da inclusão?

12-Geralmente, quais as estratégias de inclusão que o senhor utiliza?

13- Os alunos com que o senhor está trabalhando esse ano já apresentaram algum caso de agressividade?

14- Existe interação/ apoio da família na escola?

15-O senhor percebe se os pais veem crescimento dos filhos?

16-Como é o atendimento das crianças em inclusão na sala de recursos? Na sala de altas habilidades e com a pedagoga/ psicóloga? 


\section{Apêndice IV - Questões para o grupo focal com crianças}

\section{Questões para debate}

- O que chamou mais a atenção de vocês na história que lemos juntos?

- Diante disso, o que vocês entendem por Inclusão?

- Vocês percebem que aqui na escola existe a inclusão?

- Em algum momento, vocês já viveram ou presenciaram momento de exclusão? Me conte um pouco sobre isso.

- Vocês percebem que o professor de vocês, o professor Marcos, tem atitudes inclusivas? Nas séries anteriores que vocês já estudaram os professores tinham atitudes de inclusão?

Desenho sobre o que vocês entendem sobre inclusão ou como ela acontece na escola. Se quiserem, podem escrever um pequeno texto falando sobre o tema. 


\section{ANEXO I - FLUXO CURRÍCULAR DO CURSO DE PEDAGOGIA}

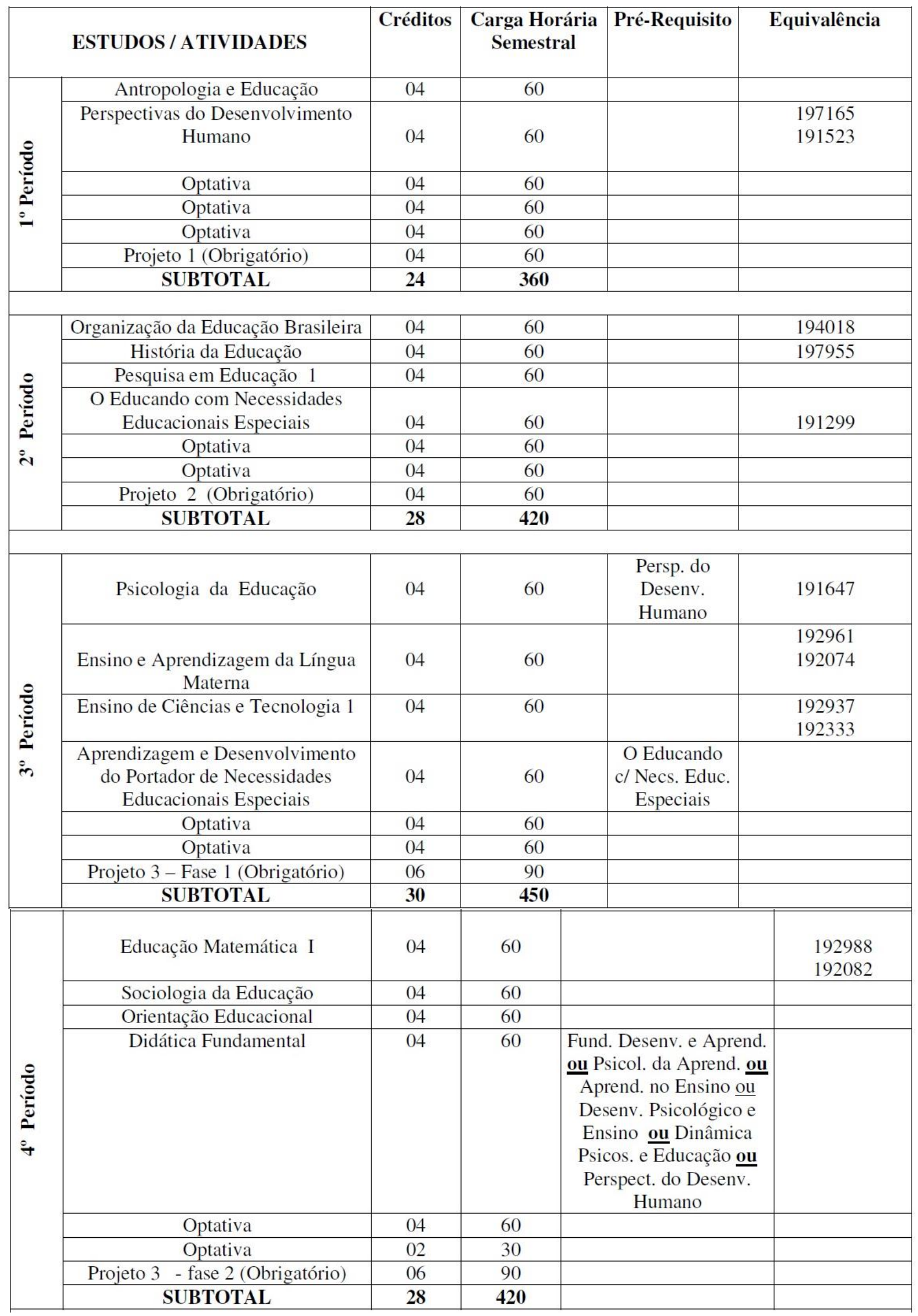




\begin{tabular}{|c|c|c|c|c|c|}
\hline \multirow{7}{*}{$\begin{array}{l}\frac{0}{0} \\
\text { in } \\
\text { in } \\
\text { in }\end{array}$} & História da Educação Brasileira & 04 & 60 & $\begin{array}{c}\text { Org. da Edu. Brasileira - } \\
\text { OEB }\end{array}$ & 191086 \\
\hline & $\begin{array}{c}\text { Administração das Organizações } \\
\text { Educativas }\end{array}$ & 04 & 60 & & 194247 \\
\hline & Processo de Alfabetização & 04 & 60 & & \\
\hline & Optativa & 04 & 60 & & \\
\hline & Libras & 04 & 60 & & \\
\hline & Projeto 3 - fase 3 (Optativo) & 06 & 90 & & \\
\hline & SUBTOTAL & 26 & 390 & & \\
\hline \multirow{7}{*}{ 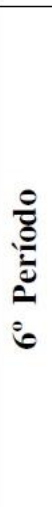 } & Políticas Públicas de Educação & 04 & 60 & & 202444 \\
\hline & Educação e Geografia & 04 & 60 & & $\begin{array}{l}192317 \\
192953\end{array}$ \\
\hline & Orientação Vocacional/Profissional & 04 & 60 & & $\begin{array}{l}191221 \\
191540 \\
207365 \\
\end{array}$ \\
\hline & Optativa & 04 & 60 & & \\
\hline & Optativa & 04 & 60 & & \\
\hline & Projeto 4 - fase 1 (Obrigatório) & 08 & 120 & & \\
\hline & SUBTOTAL & 28 & 420 & & \\
\hline \multirow{7}{*}{ 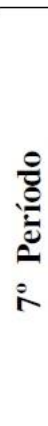 } & Filosofia da Educação & 04 & 60 & & 195651 \\
\hline & $\begin{array}{c}\text { Ensino de História, Identidade e } \\
\text { Cidadania }\end{array}$ & 04 & 60 & & $\begin{array}{l}192317 \\
192945\end{array}$ \\
\hline & Optativa & 04 & 60 & & \\
\hline & Optativa & 04 & 60 & & \\
\hline & Optativa & 04 & 60 & & \\
\hline & Projeto 4 - fase 2 (Obrigatório) & 08 & 120 & & \\
\hline & SUBTOTAL & 28 & 420 & & \\
\hline \multirow{7}{*}{ م) } & & & & & \\
\hline & Avaliação das Org. Educativas & 04 & 60 & & 194409 \\
\hline & $\begin{array}{l}\text { Projeto 5: Trabalho Final de Curso } \\
\text { (TFC) (Obrigatório) }\end{array}$ & 08 & 120 & & \\
\hline & Seminário: TFC (Optativo) & 04 & 60 & & \\
\hline & Optativa & 04 & 60 & & \\
\hline & Optativa & 02 & 30 & & \\
\hline & SUBTOTAL & 22 & 330 & & \\
\hline & TOTAL & 214 & 3210 & & \\
\hline
\end{tabular}




\section{Anexo II - Relações de Espaços Curriculares Optativas no curso}

\section{Primeiro Período}

Oficina Vivencial

Investigação Filosófica na Educação

Prática Docente e Linguagens Corporais

Atividades Lúdicas em Início de Escolarização

Fundamentos Multiculturais e Simbólicos da Educação

\section{Segundo Período}

Fundamentos da Educação Ambiental (em vias de se tornar obrigatório)

Antropologia das Organizações e Educação

Práticas Mediáticas na Educação

\section{Terceiro Período}

Educação e Trabalho (em vias de substituir O. V. P. como obrigatória)

Cultura Organizacional

Linguagens Audiovisuais na Educação

\section{Quarto Período}

Educação de Adultos

Organização da Educação no Distrito Federal

Desafios na Formação do Educador

Educação das Relações Étnicos Raciais (em vias de se tornar obrigatória)

\section{Quinto Período}

Educação infantil

Filosofia com Crianças

Educação Matemática 2

Avaliação Escolar

\section{Sexto Período}

Educação e Multiculturalismo na Contemporaneidade

Avaliação Educacional do Portador de Necessidades Educacionais Especiais

Pensamento Educacional no Brasil

\section{Sétimo Período}

Ensino de Ciência e Tecnologia 2

Planejamento Educacional

Psicologia Social na Educação 
Educação Ambiental e Práticas Comunitárias

\section{Oitavo Período}

Educação, Estética e Cultura

Gestão de Programas e Projetos Educativos

Seminários sobre Trabalho Final de Curso

Educação na Saúde

Oficinas de Textos Acadêmicos 


\section{Anexo III - Formação, Gestão e Orientação Acadêmica}

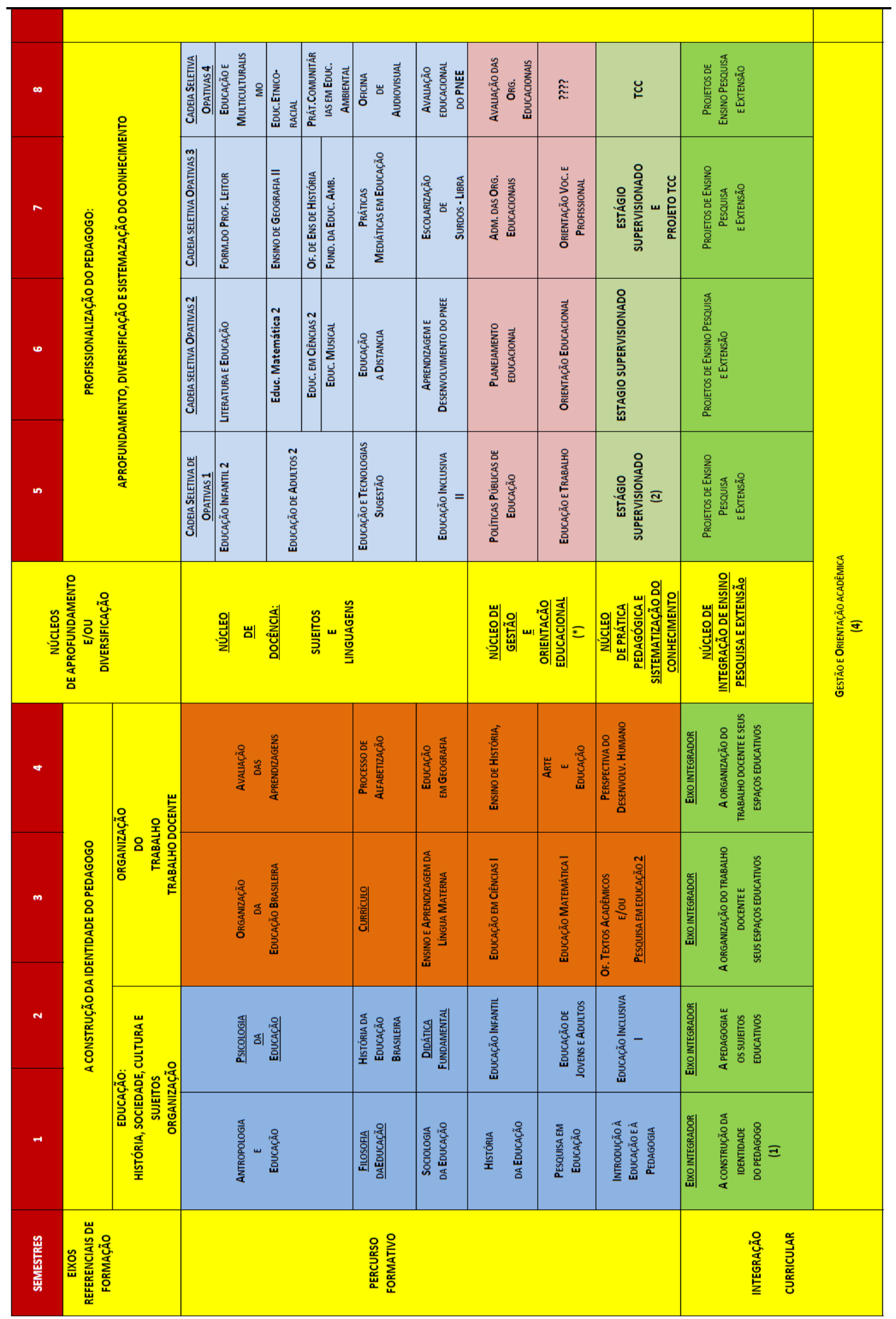




\section{Anexo IV - Ementa das Disciplinas}

\section{Universidade de Brasília \\ Secretaria de Administração Academica Listagem de Ementa/Programa}

Página Emissão: $10 / 04 / 2015$ 14:0

Órgão: FE - Faculdade de Educação

Nome da Disciplina: Aprendizagem e Desenvolvimento do PNEE

Código: 193283

Nivel: Graduação

Vigência: 2015/1

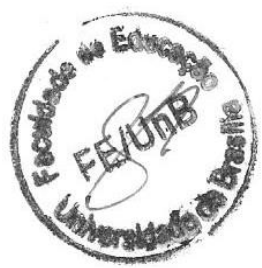

\section{EMENTA}

Estudo das caracteristicas do desenvolvimento e aprendizagem das pessoas com necessidades educacionais especiais, visando propostas educacionais Conhecer as diferentes perspectivas históricas da aprendizagem e do desenvolvimento das pessoas com necessidades educacionais especiais, possibilitando uma análise critica do contexto sócio-educacional; Compreender o processo de desenvolvimento das pessoas com necessidades educacionais especiais, como forma especifica do desenvolvimento humano; Compreensão dos principais fatores que interferem na aprendizagem das pessoas com necessidades educacionais especiais.

BIBLIOGRAFIA

Gomes, Maria de Fátima Cardoso. Relações entre desenvolvimento e aprendizagem: Consequências na Sala de Aula. Reveista Presença Pedagógica. v. 08 - n. 45,2002

Vygotski, L. S. Aprendizagem e desenvolvimento intelectual na idade escolar. Em: L. S. Vygotski; A. R. Luria e A. N. Leontiev: Linguagem, Desenvolvimento e Aprendizagem. São Paulo: İcone, 1988

Fernandes, M. L. C. N. e Magalhães, S. M. C. A. A deficiência mental na perspectiva de Piaget e Vygotski. Em R. C. Magalhães (Org.): Reflexões sobre a diferença: uma introdução à Educação Especial. Fortaleza: Demócrito Rocha, 2003

Maciel, I. M. Vygostski e a construção sócio-histórica do desenvolvimento. Em: I. M. Maciel (Org.): Psicologia e Educação: novos caminhos para a formação. Rio de Janeiro: Ciência Moderna, 2001, p. 59-77.

Valdés, M. T. M. A Educação Especial na perspectiva de Vygostski. In.: R. C. Magalhães (Org.): Reflexões sobre a diferença: uma introdução a Educação Especial. Fortaleza: Demócrito Rocha, 2003

R. C. Magalhães (Org.), Reflexões sobre a diferença: uma introdução à Educação Especial. Fortaleza: Demócrito Rocha.

REILY L. Escola Inclusiva, Linguagem e Mediação, Campinas, SP: Papirus Ed. 2004

TACCA, M.C.V.R. Aprendizagem e Trabalho Pedagógico, Campinas, SP: Alinea Ed, 2006

\section{PROGRAMA}

Módulo 1 - Perspectivas teóricas do desenvolvimento das pessoas com necessidades educacionais especiais

Semana 2 e 3

${ }^{\star}$ A Educação e o binômio aprendizagem e desenvolvimento

*Aprendizagem e desenvolvimento: diferentes abordagens teóricas

Semana 4 e 5 :

*Orientações teóricas: desenvolvimento e aprendizagem das pessoas com Necessidades educacionais especiais

${ }^{*}$ A perspectiva histórico-cultural: concepçōes teóricas sobre a relação desenvolvimento/aprendizagem das pessoas com necessidades educacionais especiais.

Módulo 2- A unidade do Desenvolvimento Infantil: compreensão do desenvolvimento das pessoas com necessidades educacionais especiais

\section{Semana 7,8 e 9}

*Os fundamentos da Defectologia de Vygotsky. Principios e conceitos básicos para a compreensão do desenvolvimento das pessoas com deficiências

*Contextos de desenvolvimento do aluno com necessidades educacionais especiais : a família e a escola

Módulo 3 - Os processos de aprendizagem dos alunos com necessidades educacionais especiais

Semana 11,12 e 13

*Processo de ensino-aprendizagem e relação professor-aluno. Elaboração de estratégiâs de ensino e aprendizagem. aprendizagem e dificuldades de ensino: o trabalho pedagógico na Educação Inclusiva.

*Criatividade no trabalho pedagógico e criatividade na aprendizagem. 
Universidade de Brasilia

Secretaria de Administração Academica Listagem de Ementa/Programa
Página $\quad 1$ de

Emissão: 10/04/2015 14:

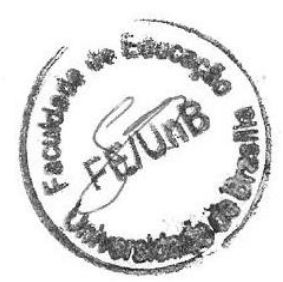

Nome da Disciplina: Educando com Necessidades Educacionais Especiais

Código: 197947

Nivel: Graduação

Vigência: 2015/1

EMENTA

O ensino especial face ao contexto histórico sócio político cultural e educacional atual; o conceito de diversidade e categorias de necessidades

educacionais especiais para fins de atendimento a alunos com deficiência: mental, fisica, visual, auditiva, múltipla, altas habilidades, dificuldades de

aprendizagem e outras minorias na realidade da escola inclusiva. Análise das especificidades educacionais e das potencialidades destes alunos. O papel e a preparação do professor.

BIBLIOGRAFIA

MBRASIL. Parâmetros Curriculares Nacionais. Adaptações Curriculares

- Estratégias para a Educação de Alunos com Necessidades Educacionais Especiais. Brasília: 1999

BRASIL. Diretrizes Nacionais para a Educação Especial na Educação Básica. Ministério da Educação - Conselho Nacional de Educação, nº 177 - Seção 1 , sexta-feira, 14 de Setembro. Brasília, Diário Oficial, 2001.

CARVALHO, Rosita Edler. Diferença, deficiência e necessidades educacionais especiais. Mimes, 1996.

DECLARAÇÃO DE GUATEMALA. Guatemala, 2001. Disponivel em: http://wnw. oas.org/juridico/portuguese/treaties/A-65.htm

DECLARAÇÃO DE SALAMANCA. Espanha, 1994.Disponivel em: http://

portal.mec.gov.br/seesp/arquivos/pdf/salamanca.pdf

DECLARACCÃO MUNDIAL SOBRE EDUCAÇÃO PARA TODOS. Tailândia, 1990. Disponivel em: http://www. pitangui.uepg.br/nep/documentos/Declaracao $\% 20-\% 20$ jomtien $\% 20-\% 20$ tailandia.pdf

FONTES, Rejane de S; LANDI, Maria de L F. (1997). MEC - Estigmas: Uma Prisão sem Grade. Revista: Integração. Educação Especial. Brasília.

FONTES, Rejane de S.(2002). Inclusão escolar - Boa para quem? Revista Presença Pedagógica, v. $8 n^{\circ} 43$ - jan./ fev.

JUNIOR, Renato P. (2001). Avaliação e desigualdades escolares. Revista Presença Pedagógica, v.7 nº 42, novidez.

PÁEZ,Stella C. De.A diversidade como valor: uma estratégia para a integração escolar. Projeto - Revista de educação: Inclusão. Porto Alegre, v.5, $n^{\circ} 7$, 2003.

SOUZA, Vânia M. de C. B. de; MARTINS, Maria C. (2001). Avaliação a partir do potencial do aluno. Revista Psicopedagógica $19 / 58-54-58$ dezembro.

TUNES, Elizabete. Por que falamos de inclusão? Linhas Críticas. Universidade de Brasília, Faculdade de Educação. Vol. 9 n 16 (janeiro a junho 2003). Brasilia, DF: UnB.

PROGRAMA
O conteúdo foi detalhado em 3 unidades, que apresentam uma visão panorâmica - a perspectiva histórica, o estado atual, os desafios e as potencialidades - sobre os aspectos do ensino inclusivo.

Unidade 1 - Educação Especial.

- Fundamentos sócio-históricos e filosóficos da educação especial: evolução do conceito e do atendimento em educação especial e sua caracterização histórica.

- A educação especial contextualizada na educação geral e suas interrelações para a educação das pessoas com necessidades especiais

• Educação especial no Brasil: políticas públicas e organização.

Unidade 2 - Educação inclusiva.

- Bases legais, principios e conceitos axiológicos da educação inclusiva.

- A sociedade e as necessidades especiais: discriminação, estigma, exclusão e inclusão social e educacional.

- Significação atual dos conceitos de necessidades especiais, diversidade, diferença, deficiência e preconceito

- Perspectivas das redes de apoio da educação inclusiva: familia, escola e comunidade.

Unidade 3 - Necessidades educacionais especiais e prática

pedagógica.

- Educandos com necessidades educacionais especiais

- Práticas pedagógicas, programas e serviços educacionais na escola inclusiva.

- Características e competências do professor para educação

inclusiva. 
Universidade de Brasília

Secretaria de Administração Academica Listagem de Ementa/Programa

Órgão: TEF - Departamento de Teoria e Fundamentos Nome da Disciplina: Escolarização de Surdos e LIBRAS Código: 100749

Nivel: Graduação

Vigência: 2015/1
Página

1 de

Emissão: 10/04/2015

\section{EMENTA}

Nada Consta

BIBLIOGRAFIA

Nada Consta

PROGRAMA

Nada Consta 
Anexo V- Turma da Mônica em Inclusão Social

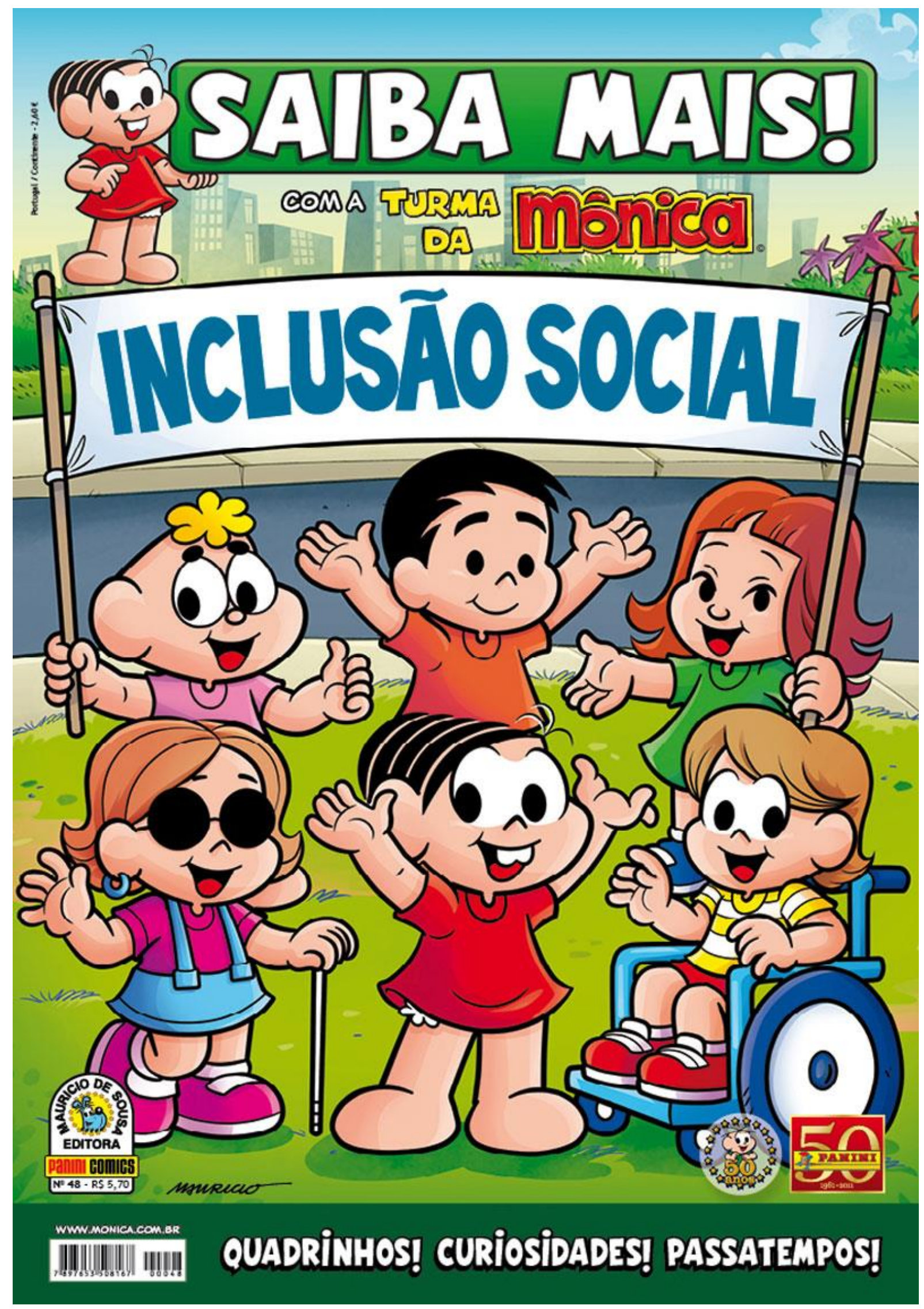



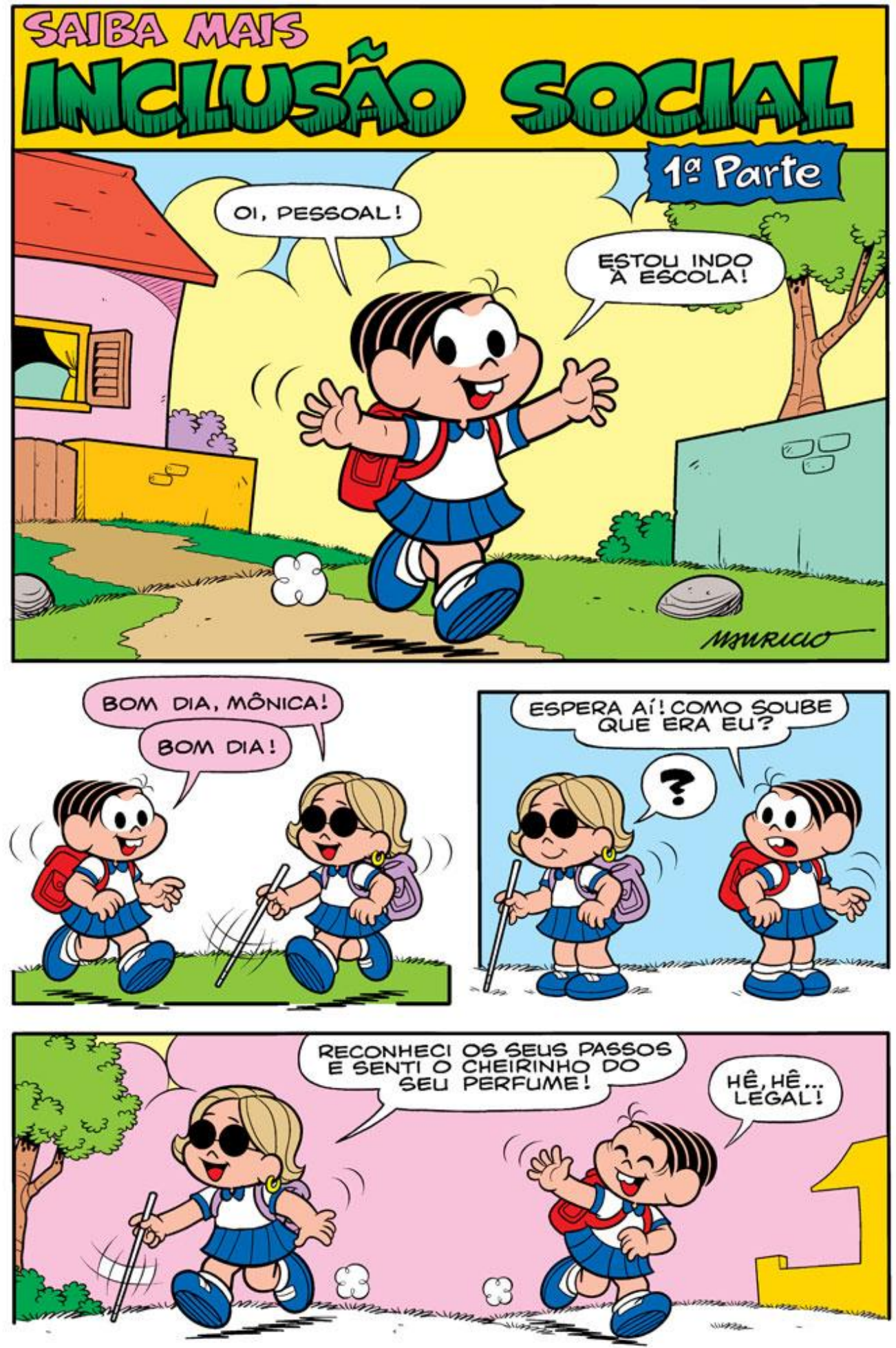


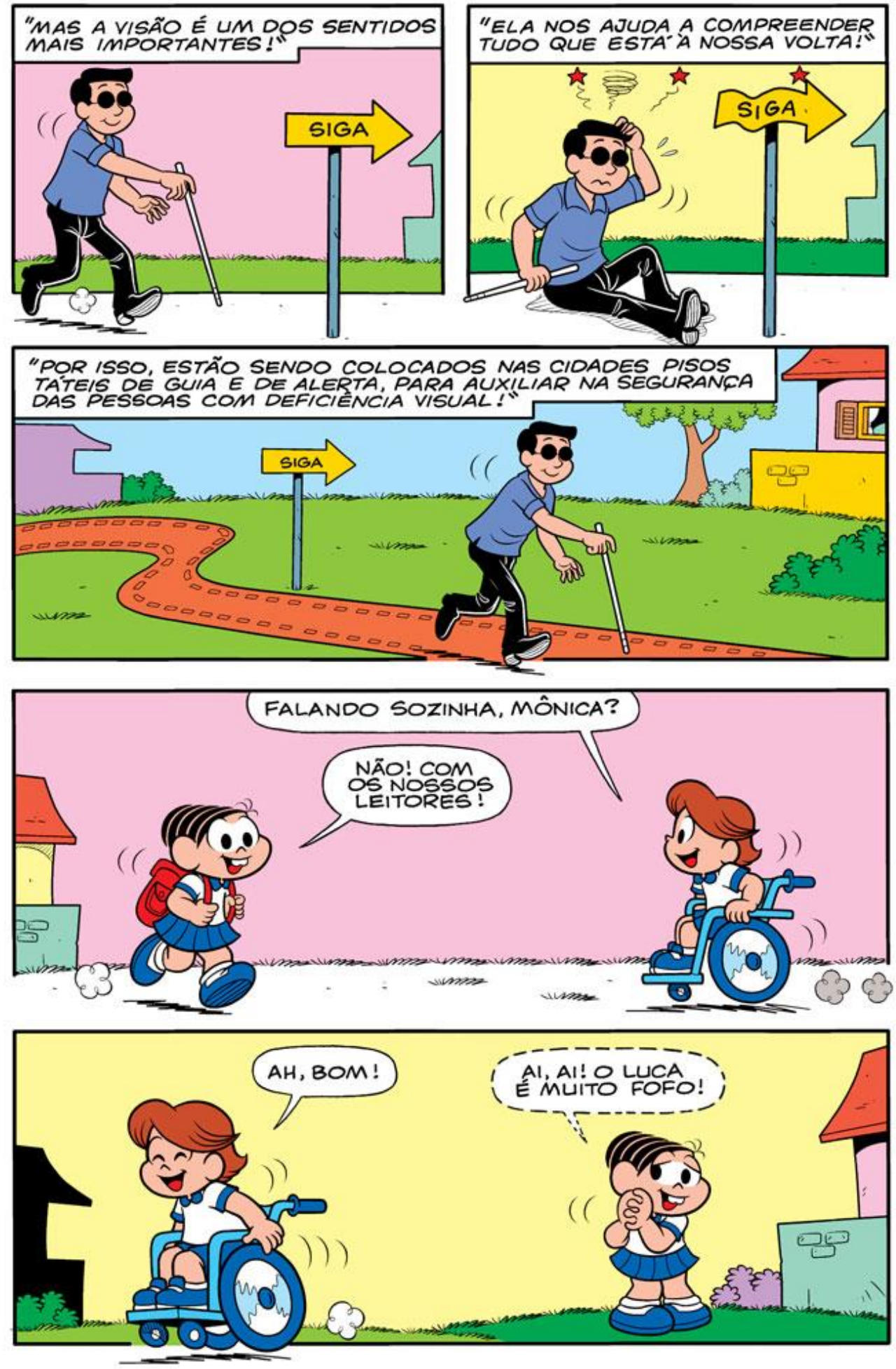

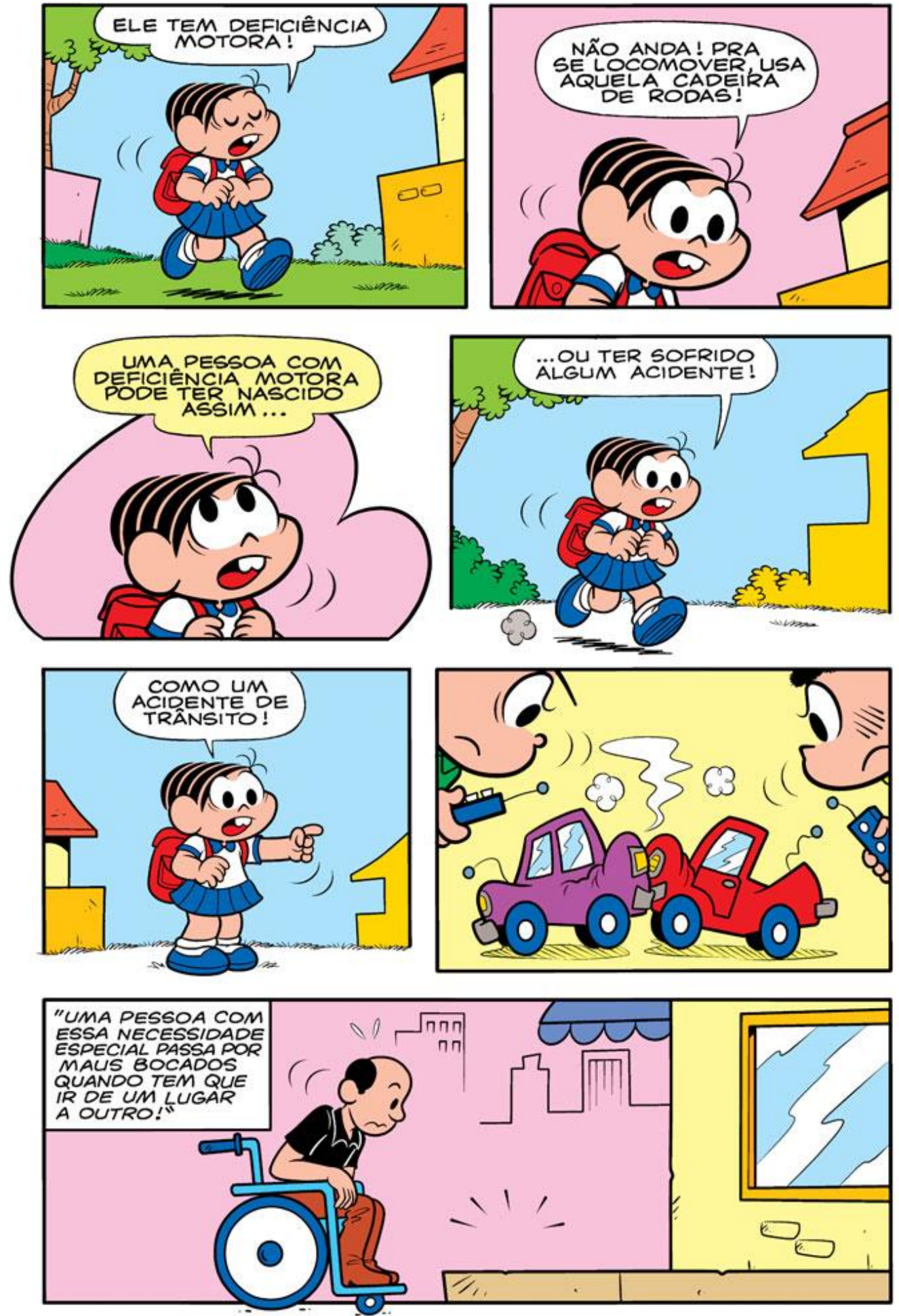

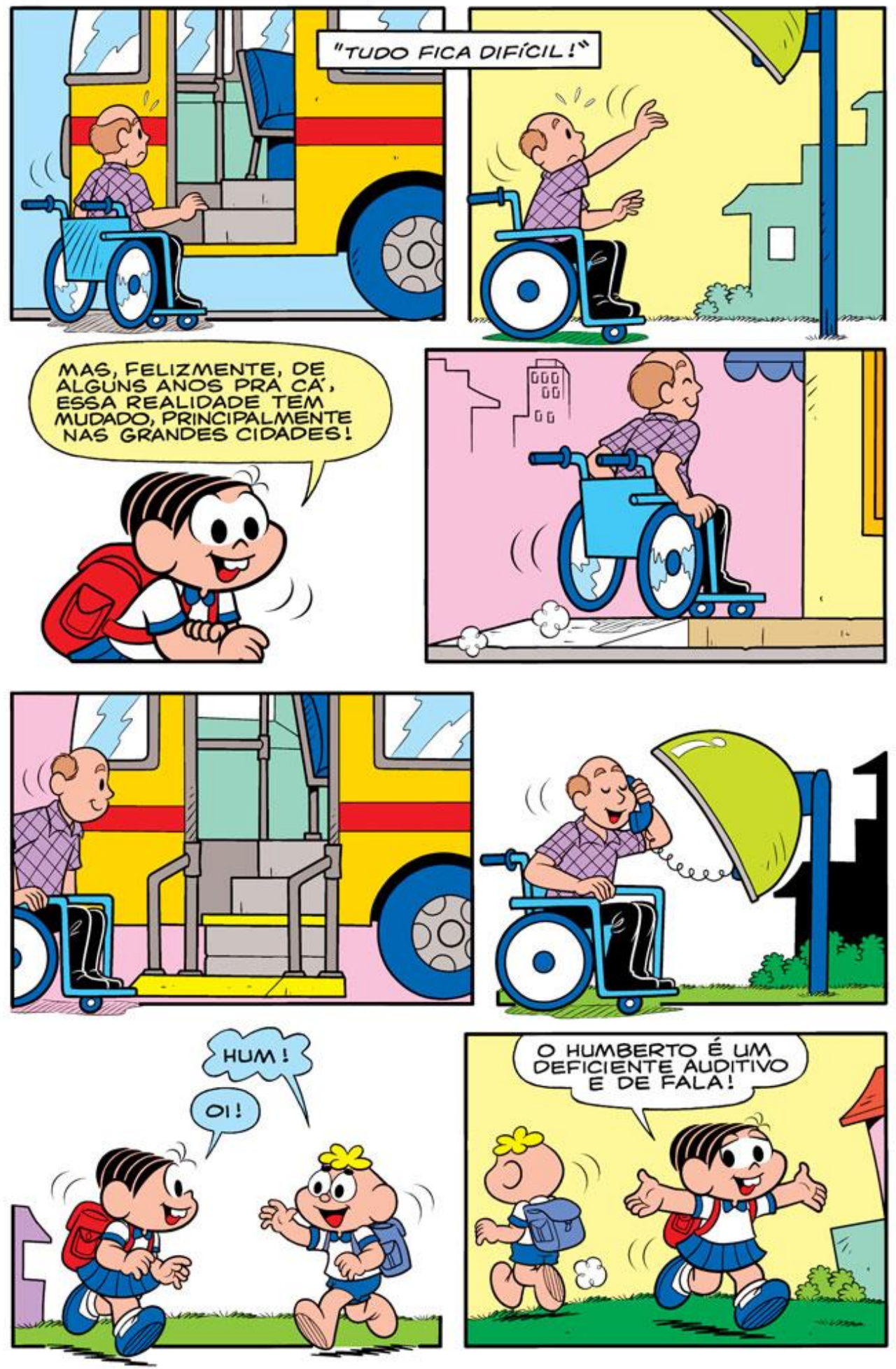

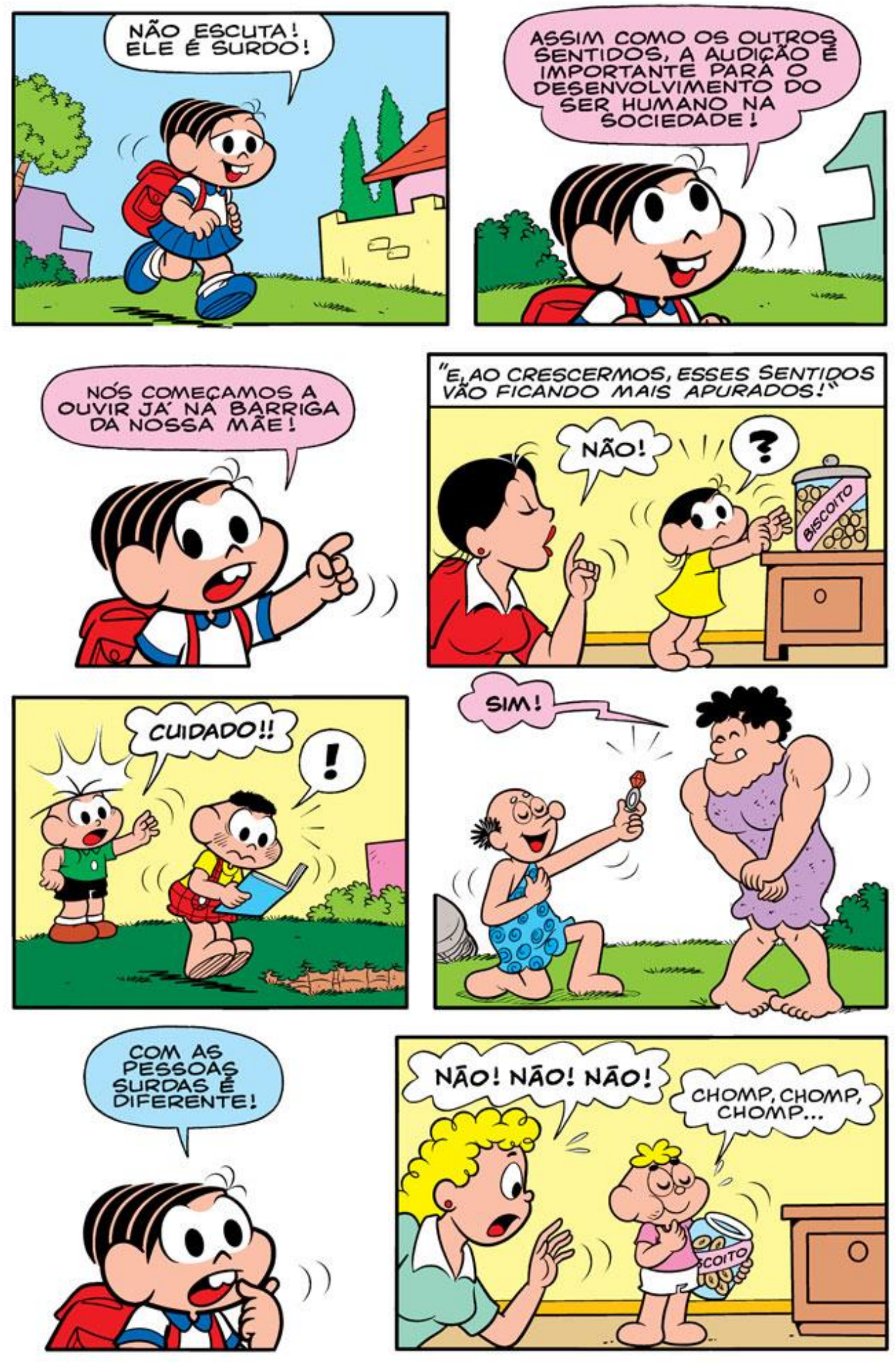

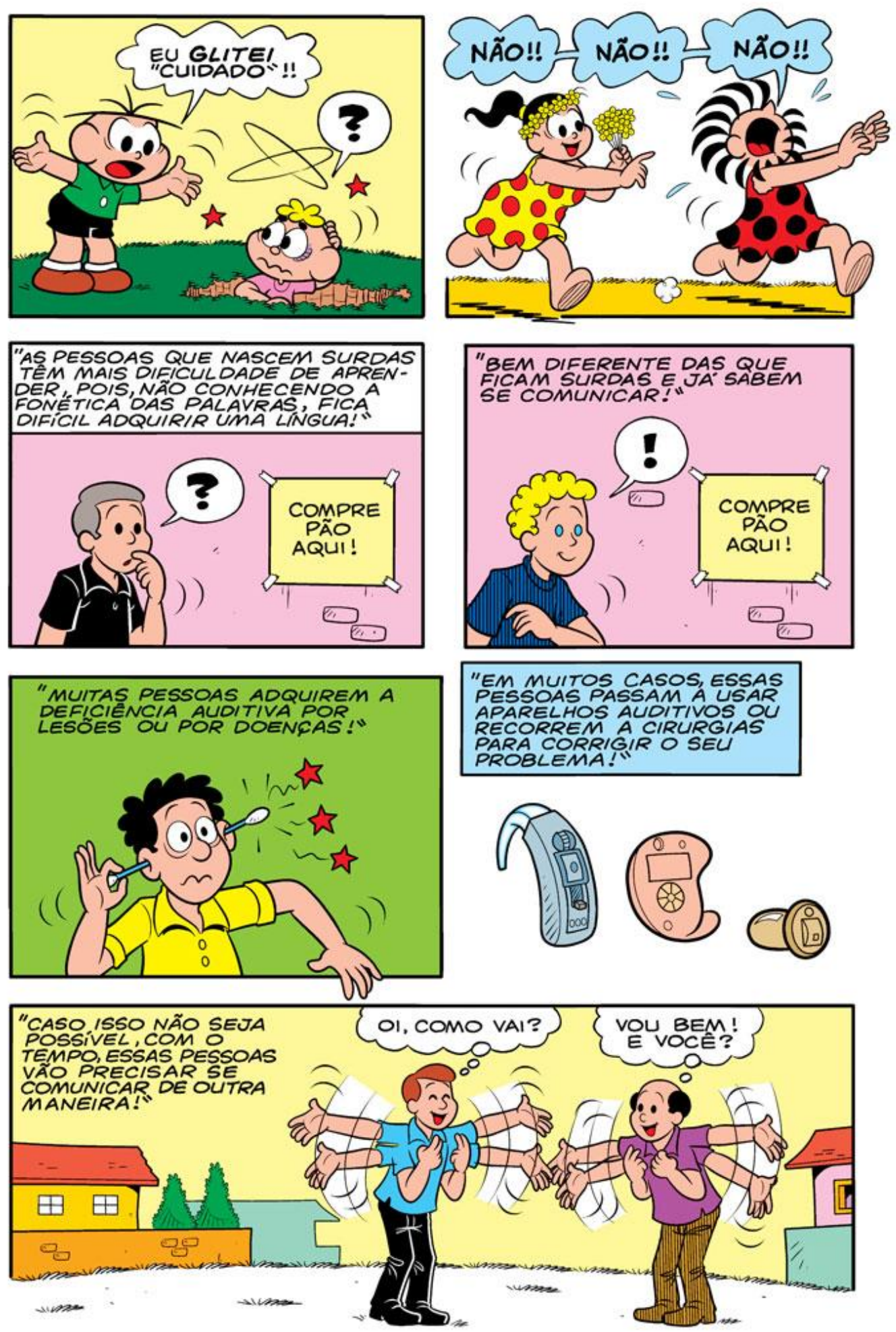


\section{ALFABETO DOS SINNAISS}

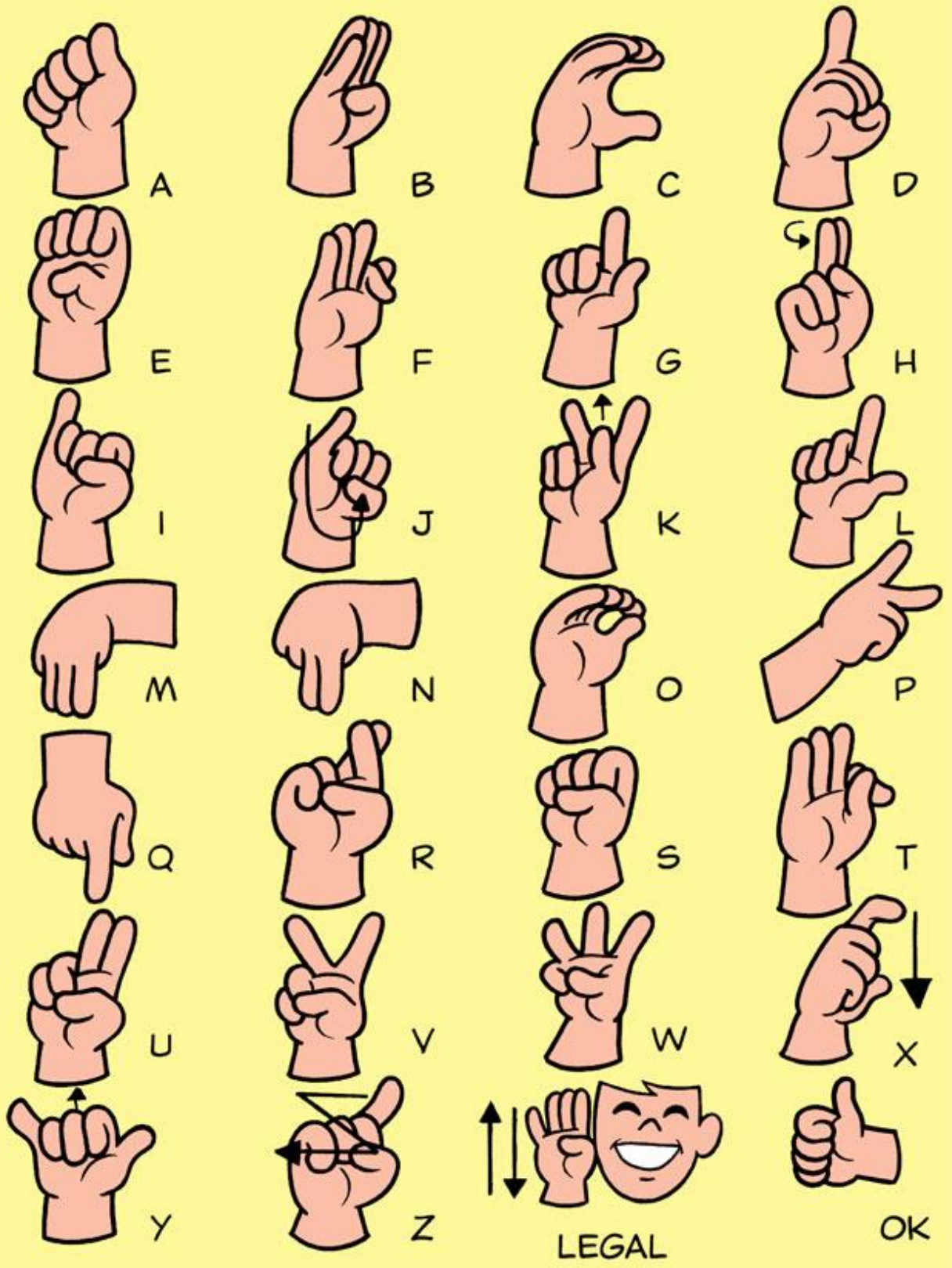



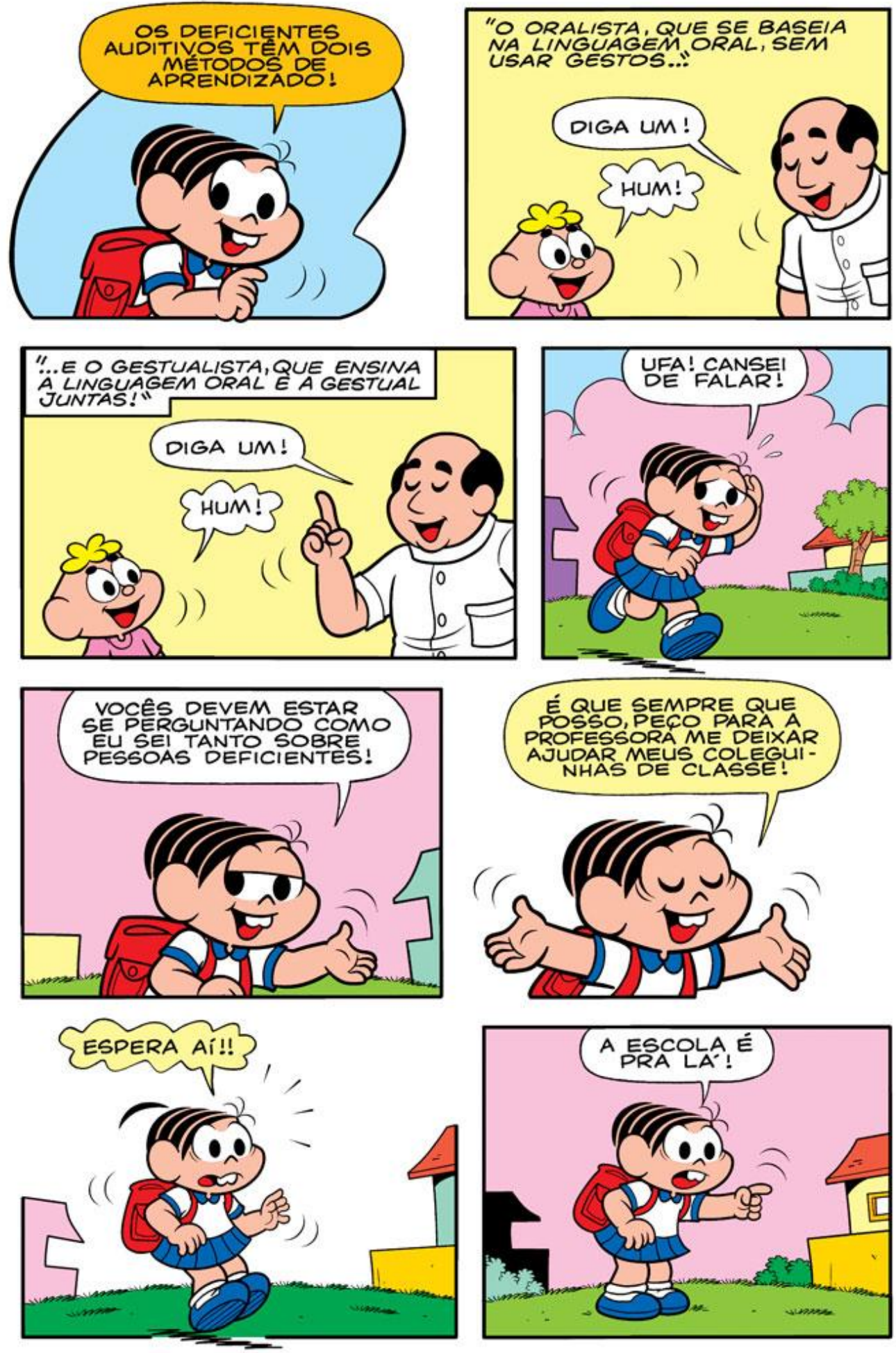

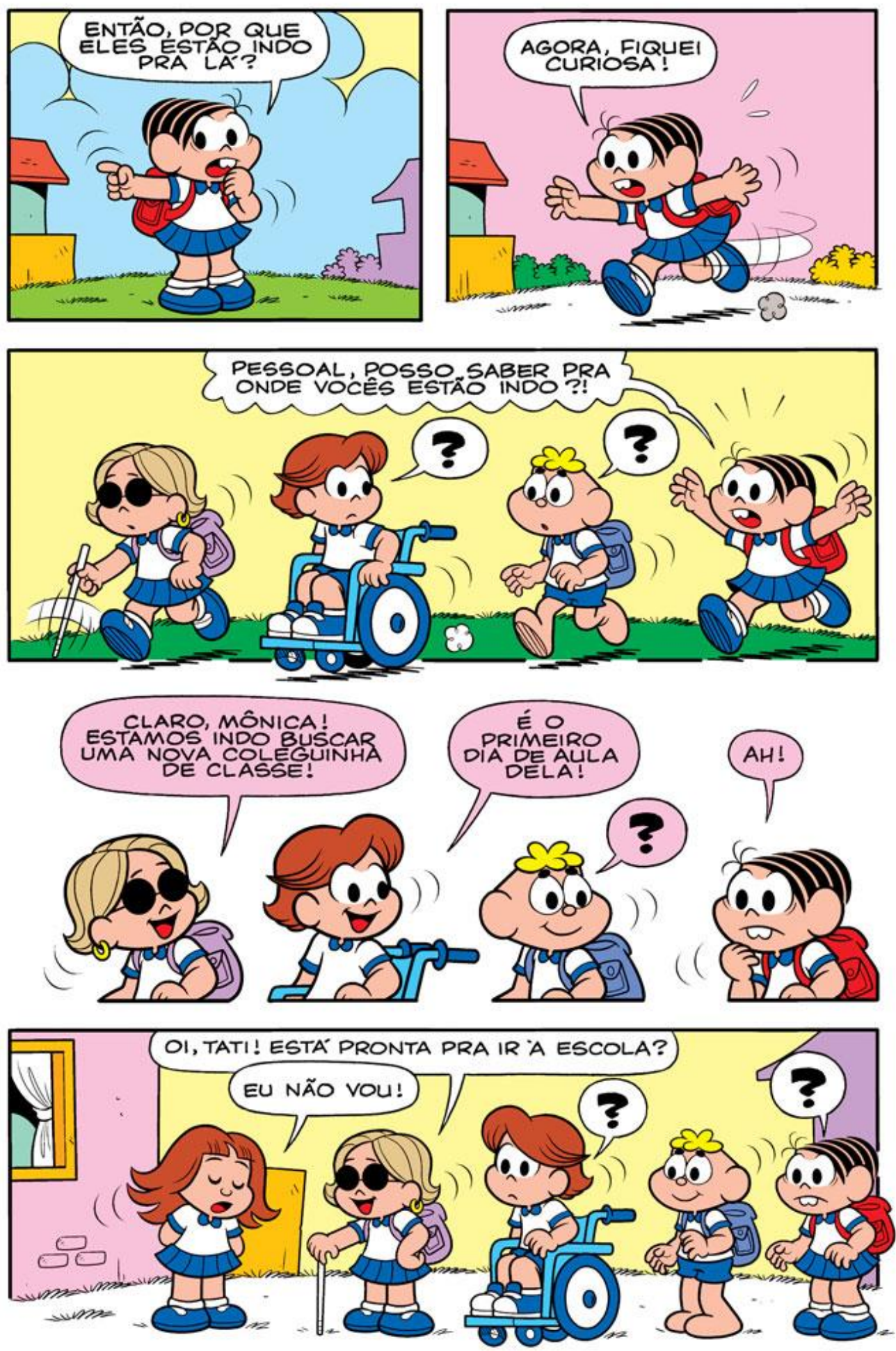

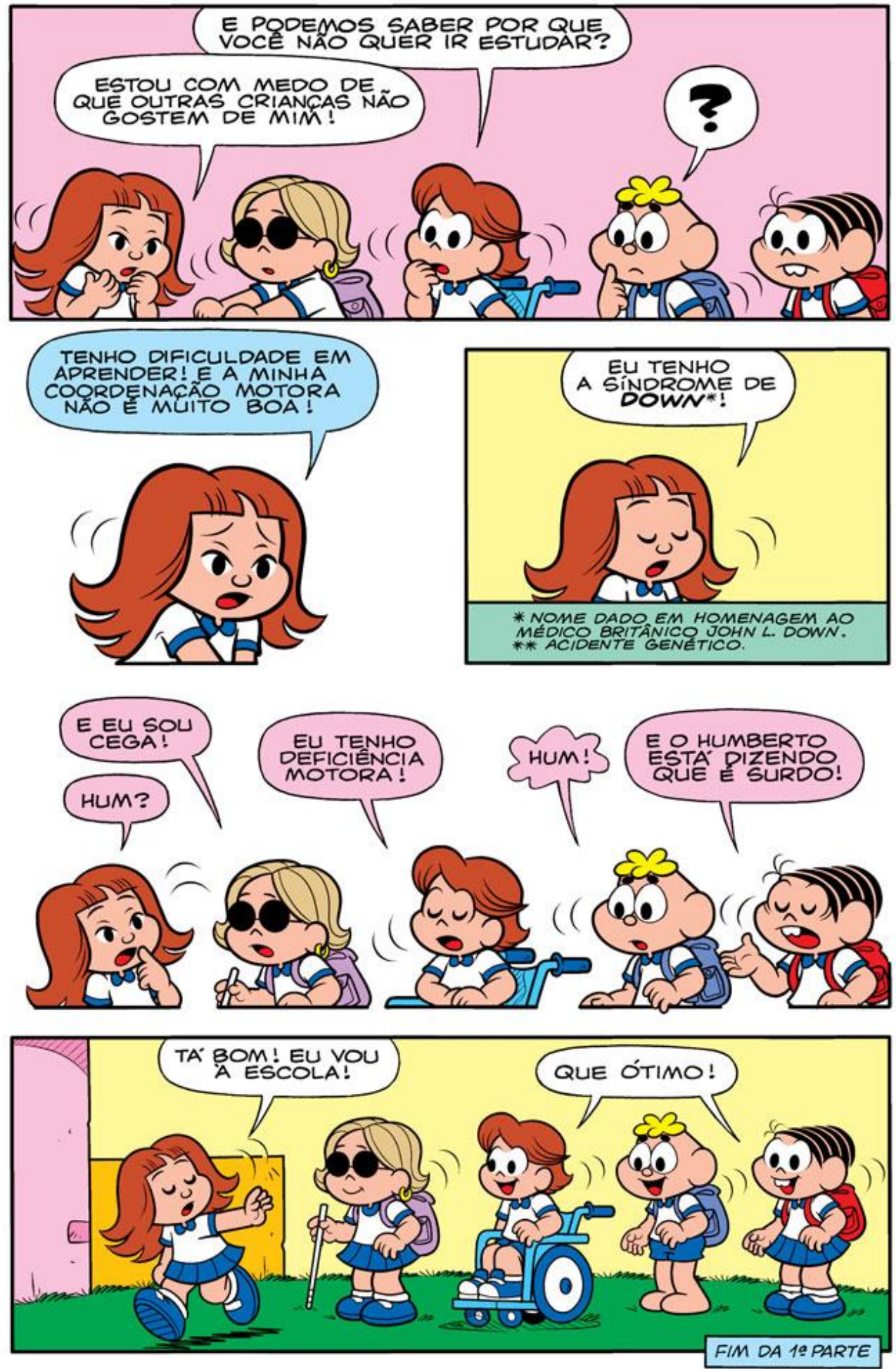


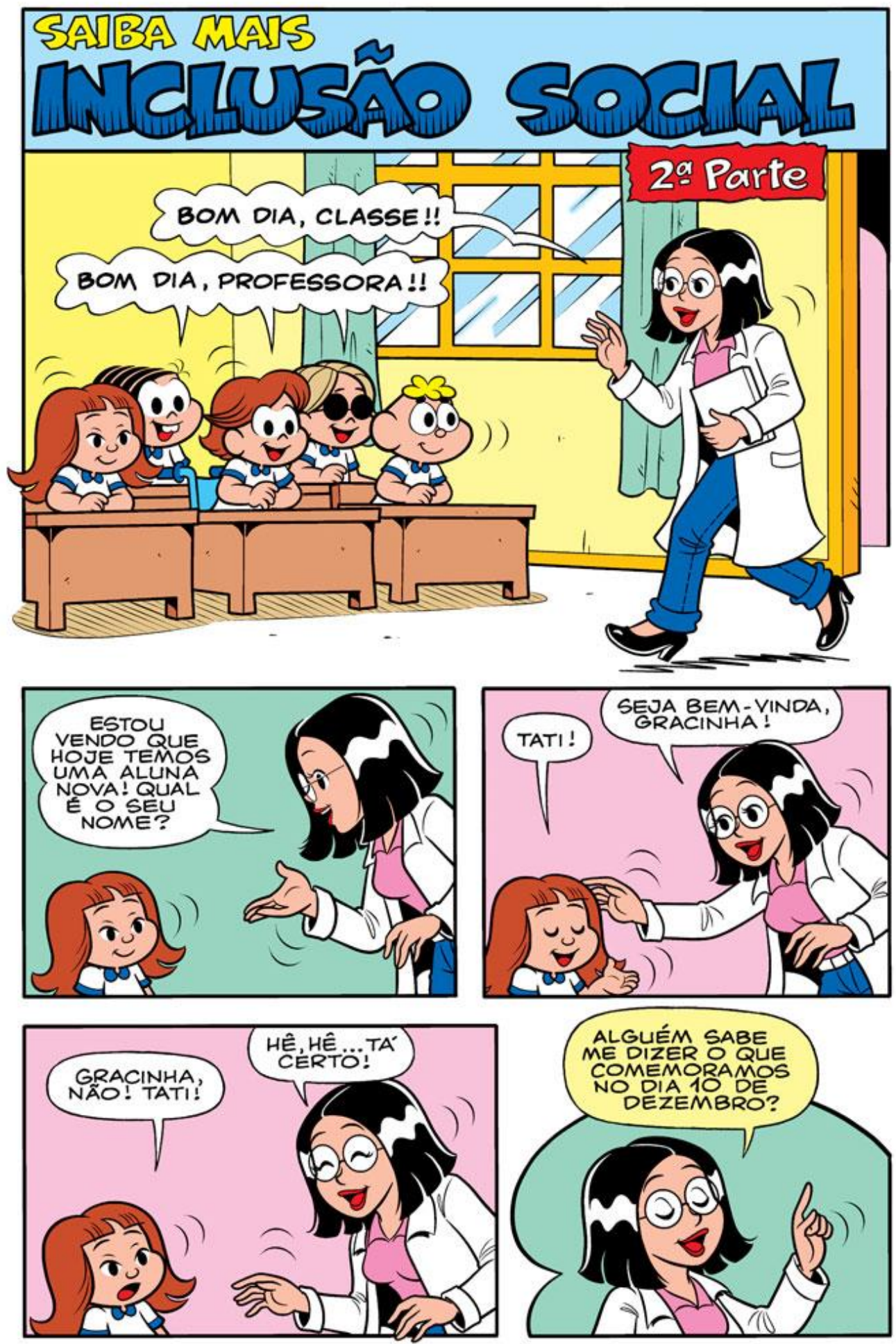



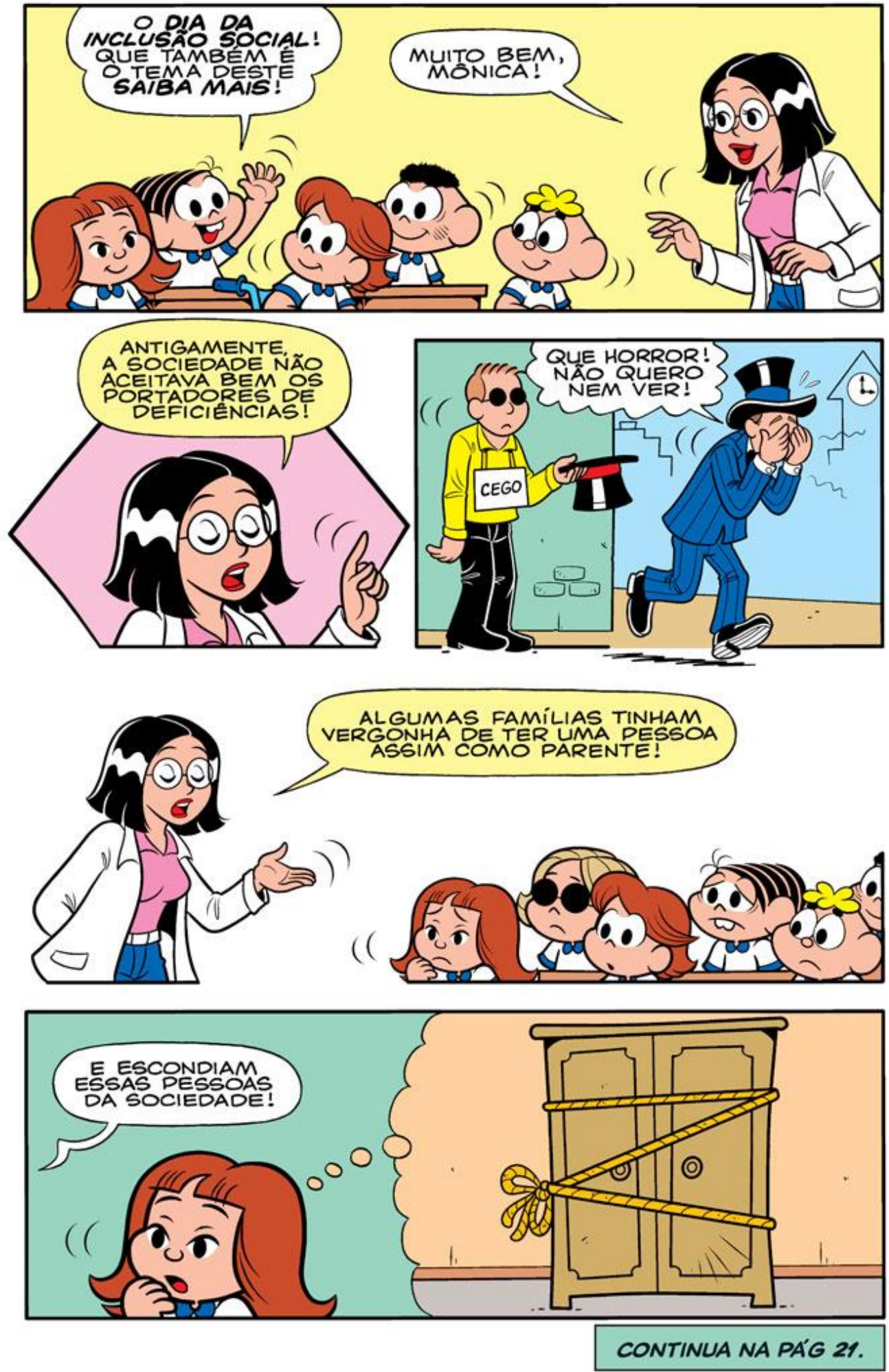

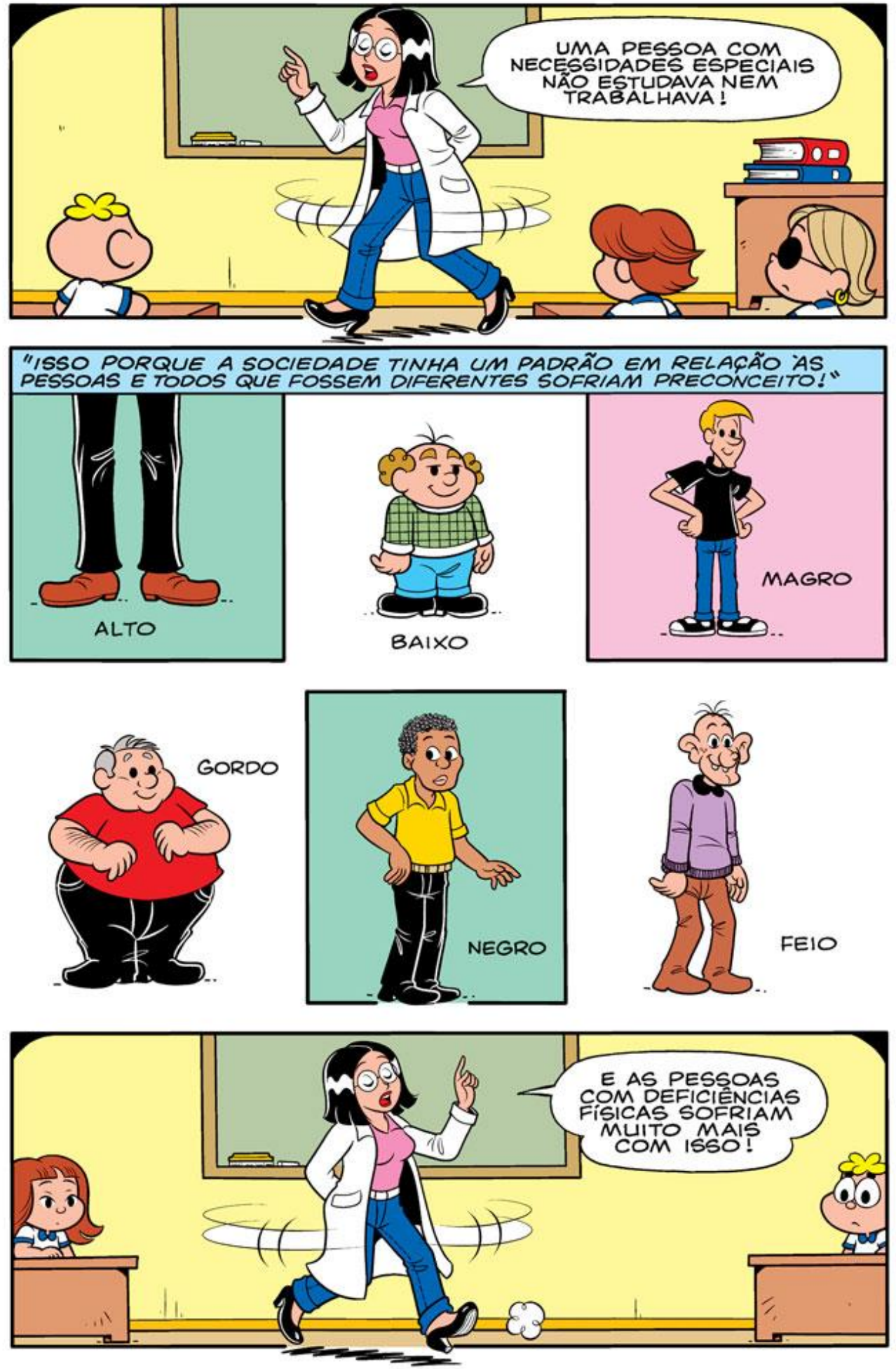

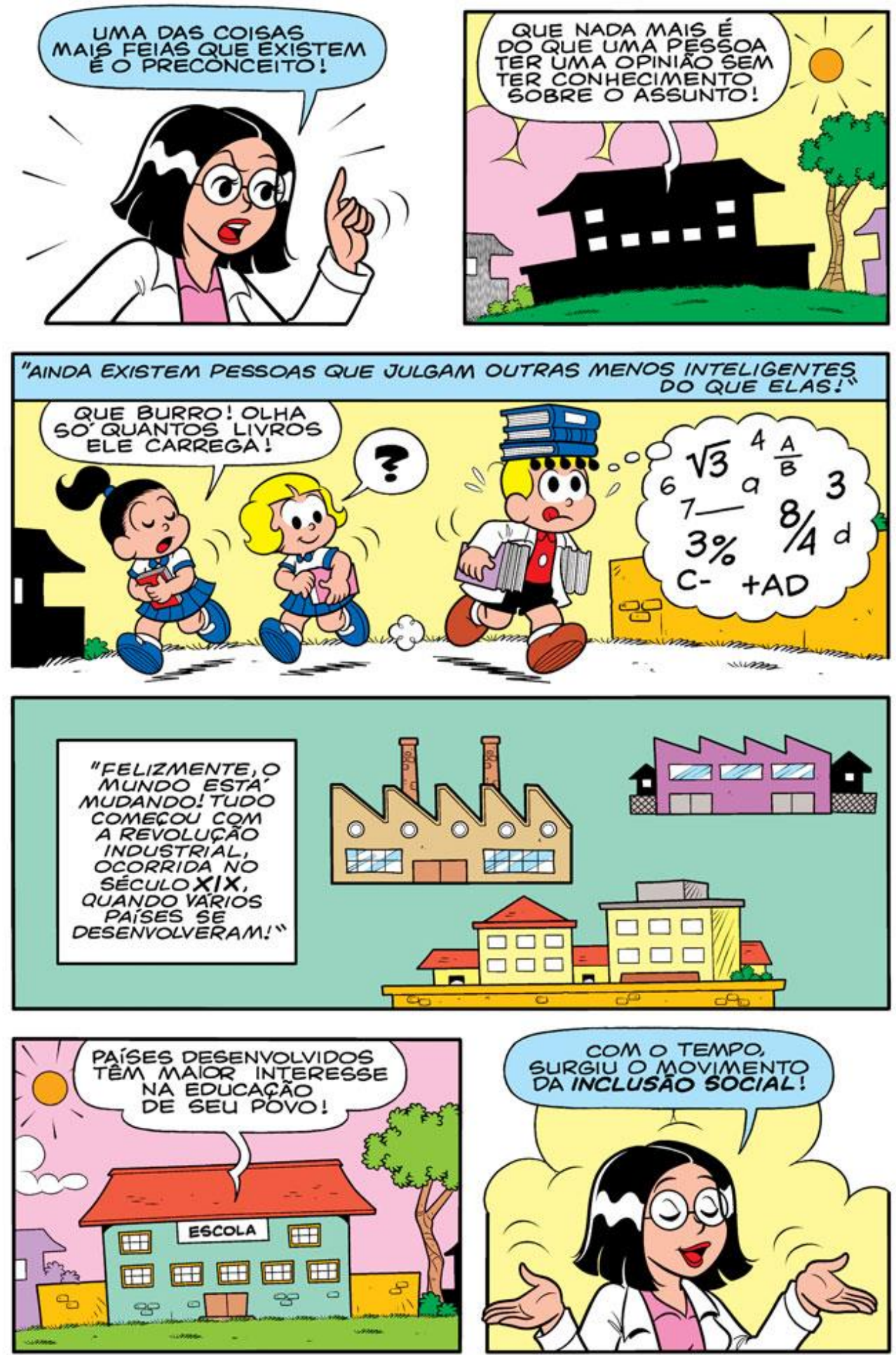

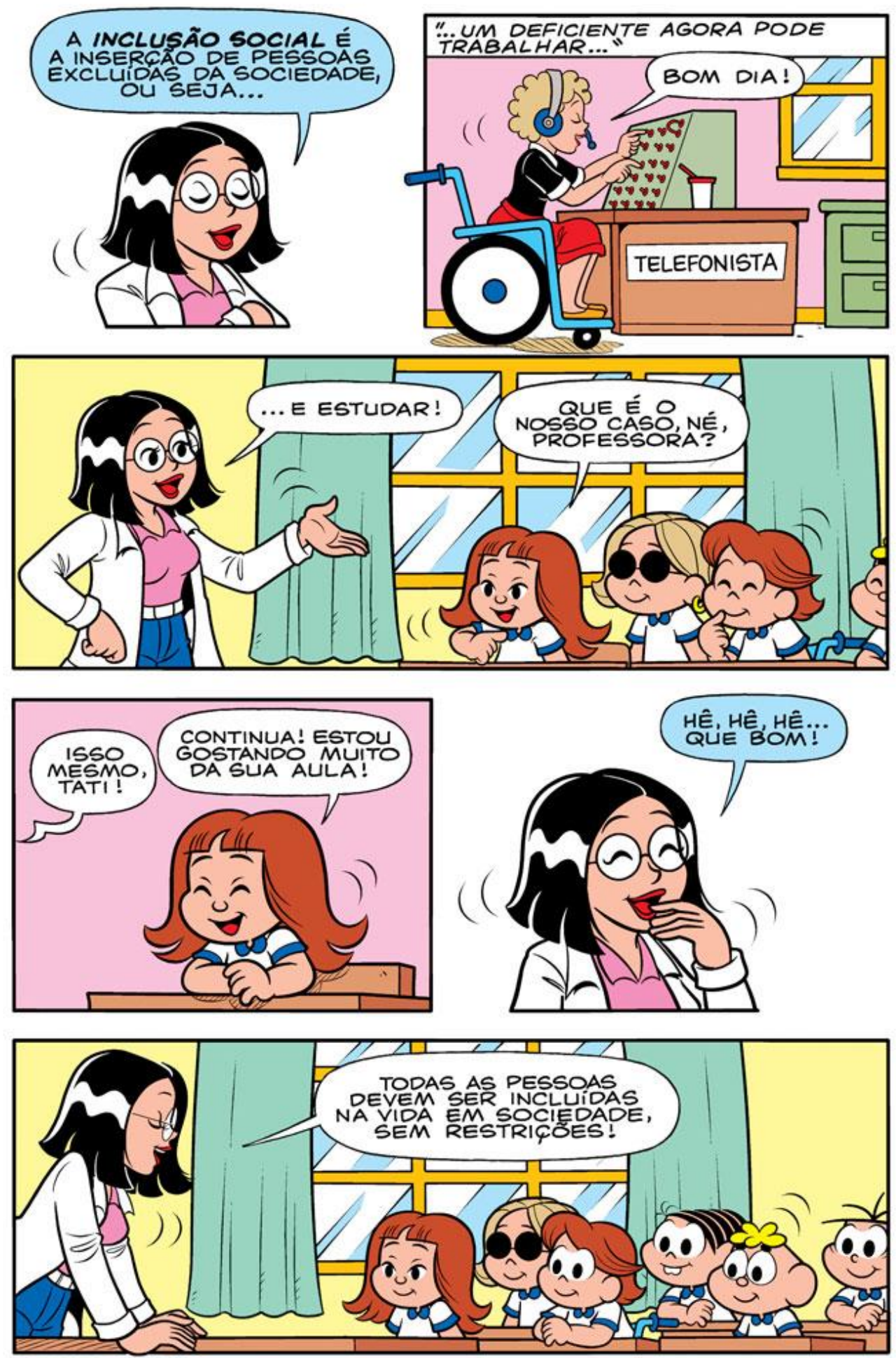


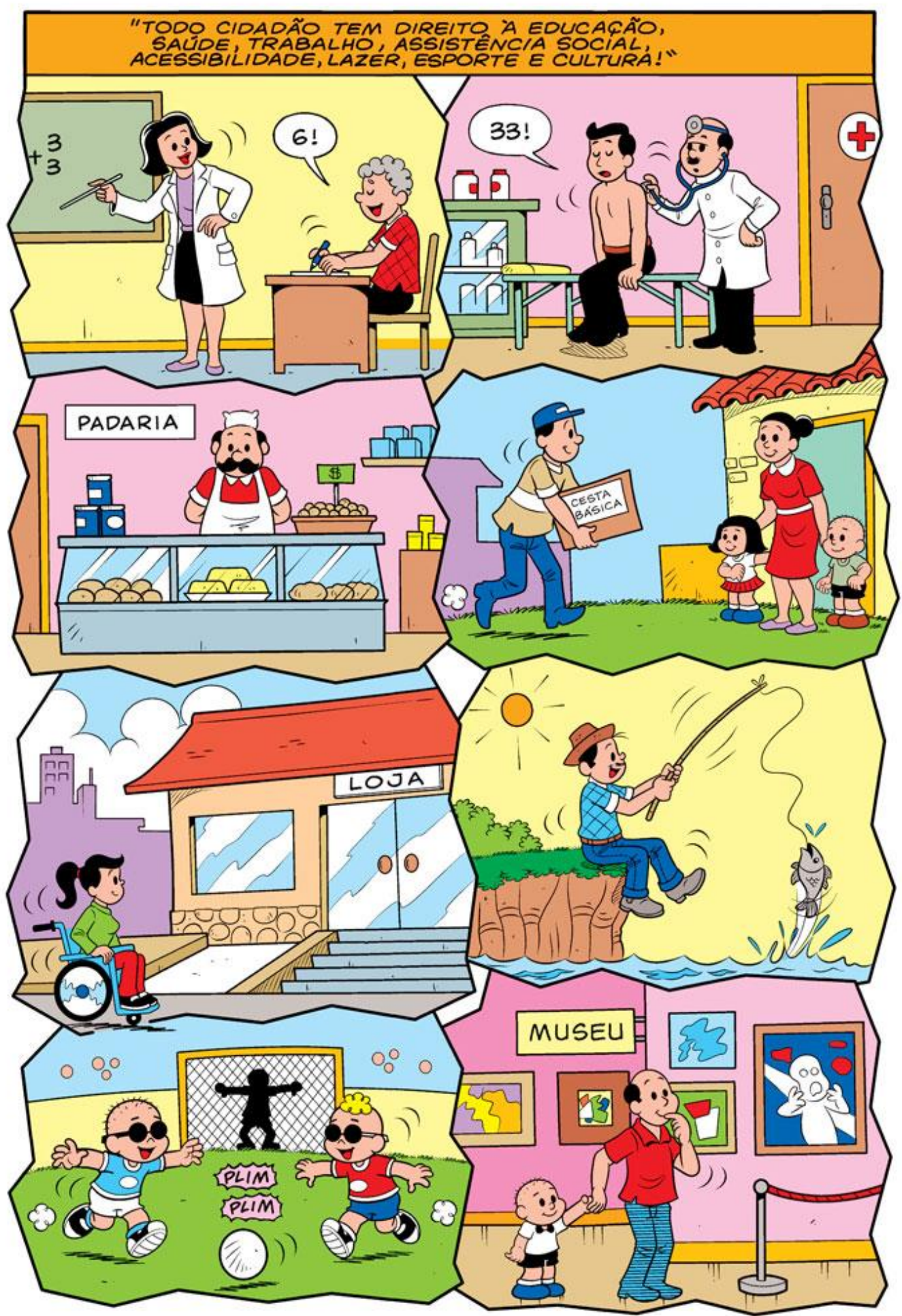



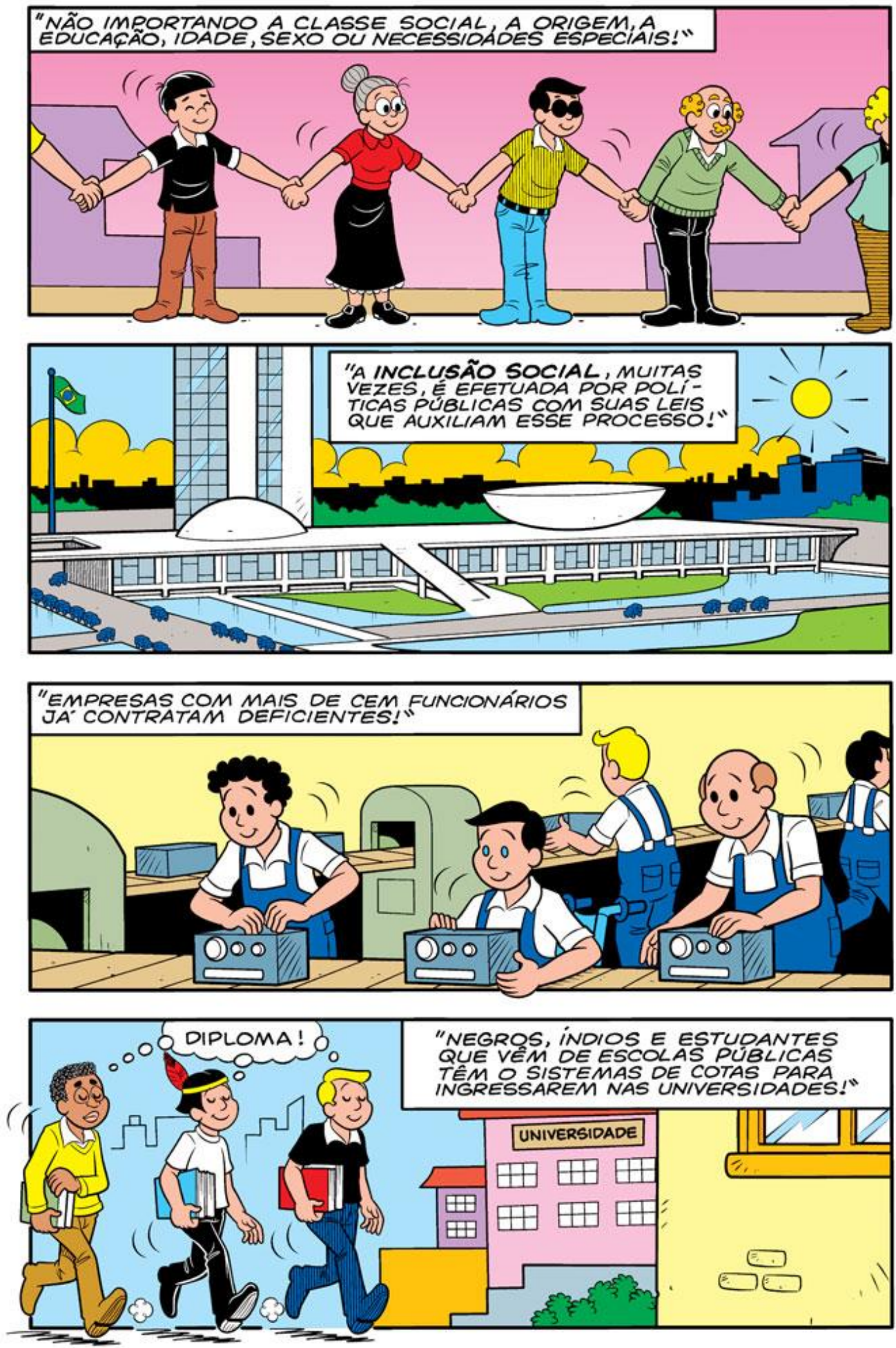

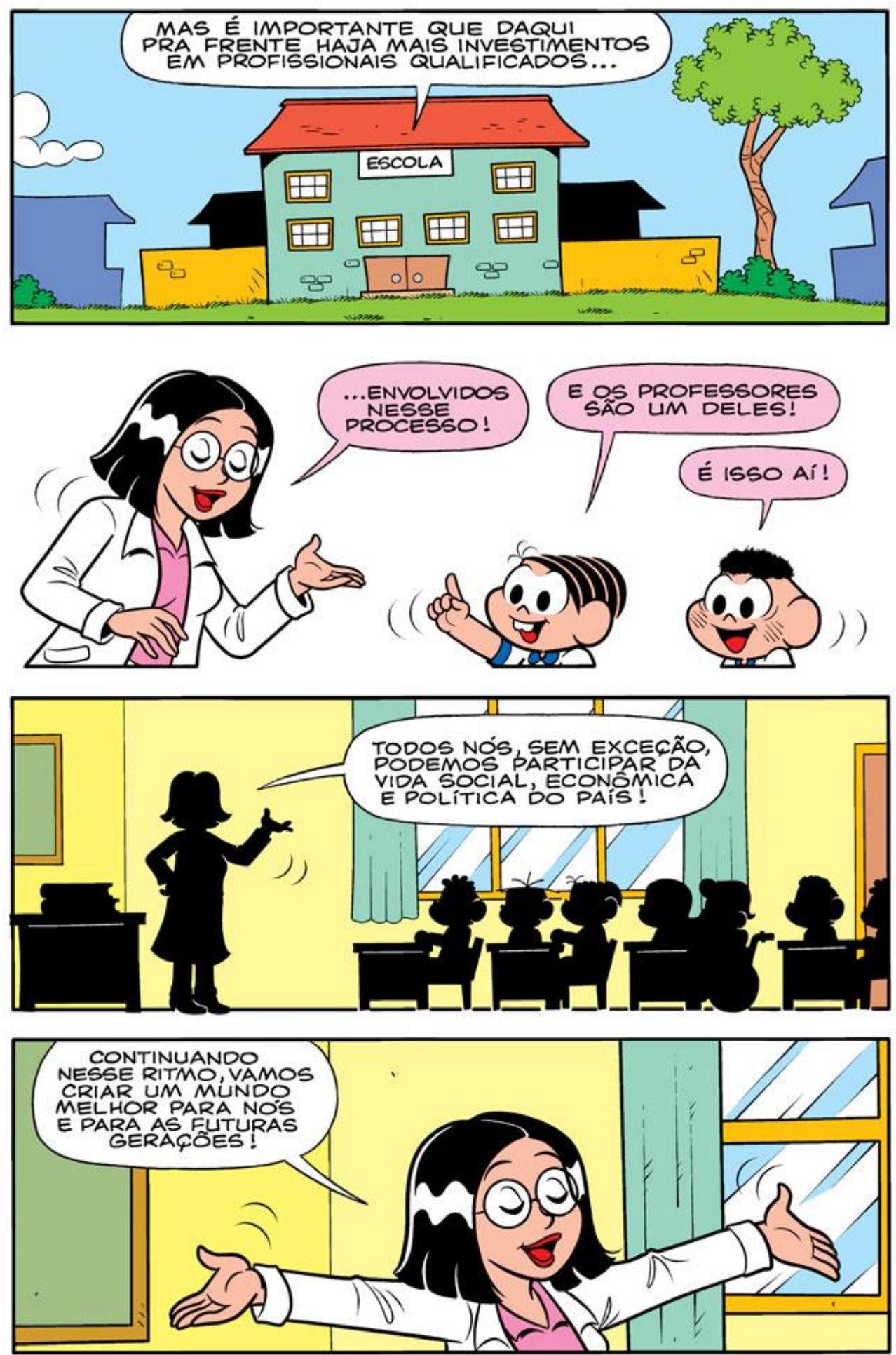

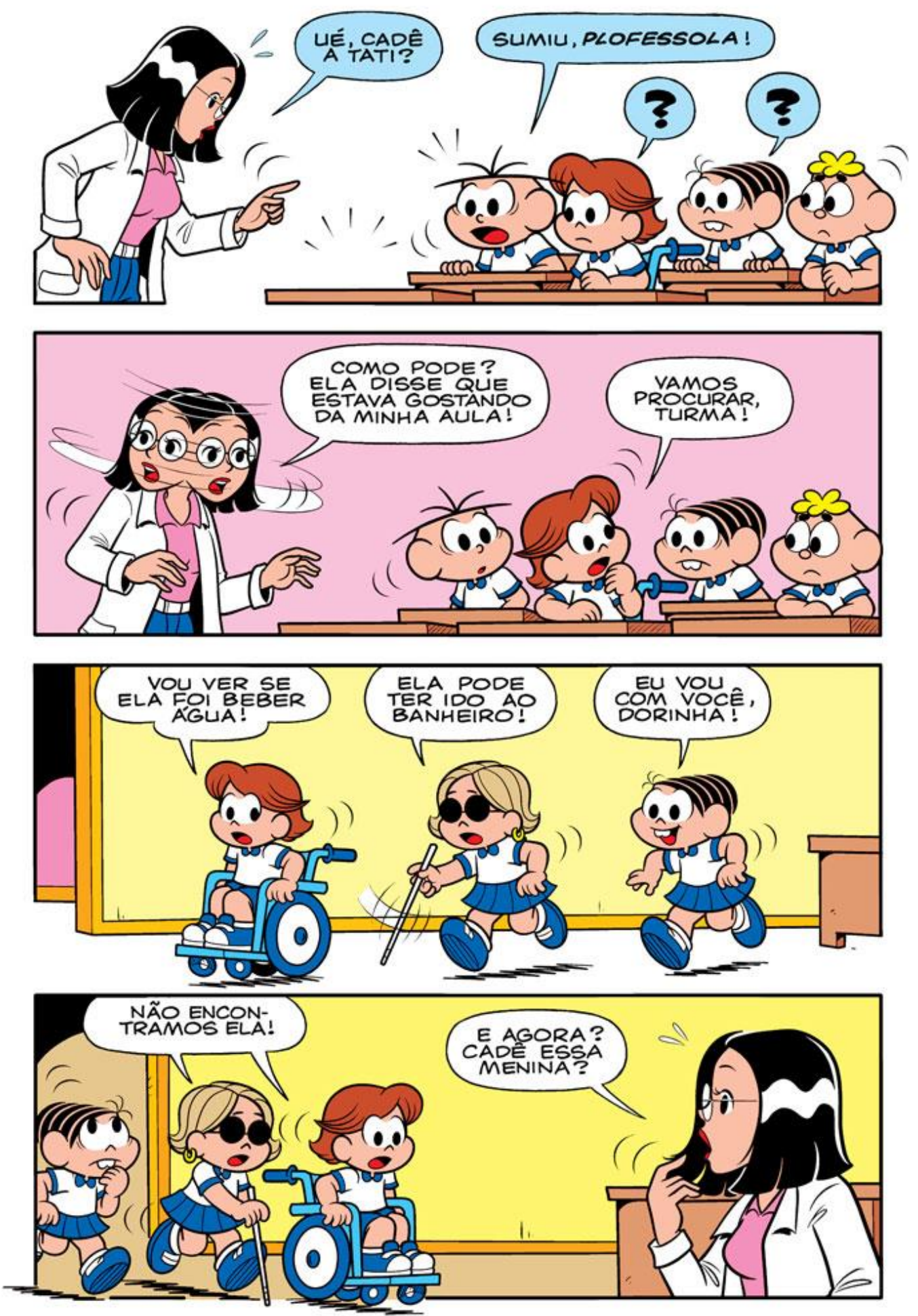

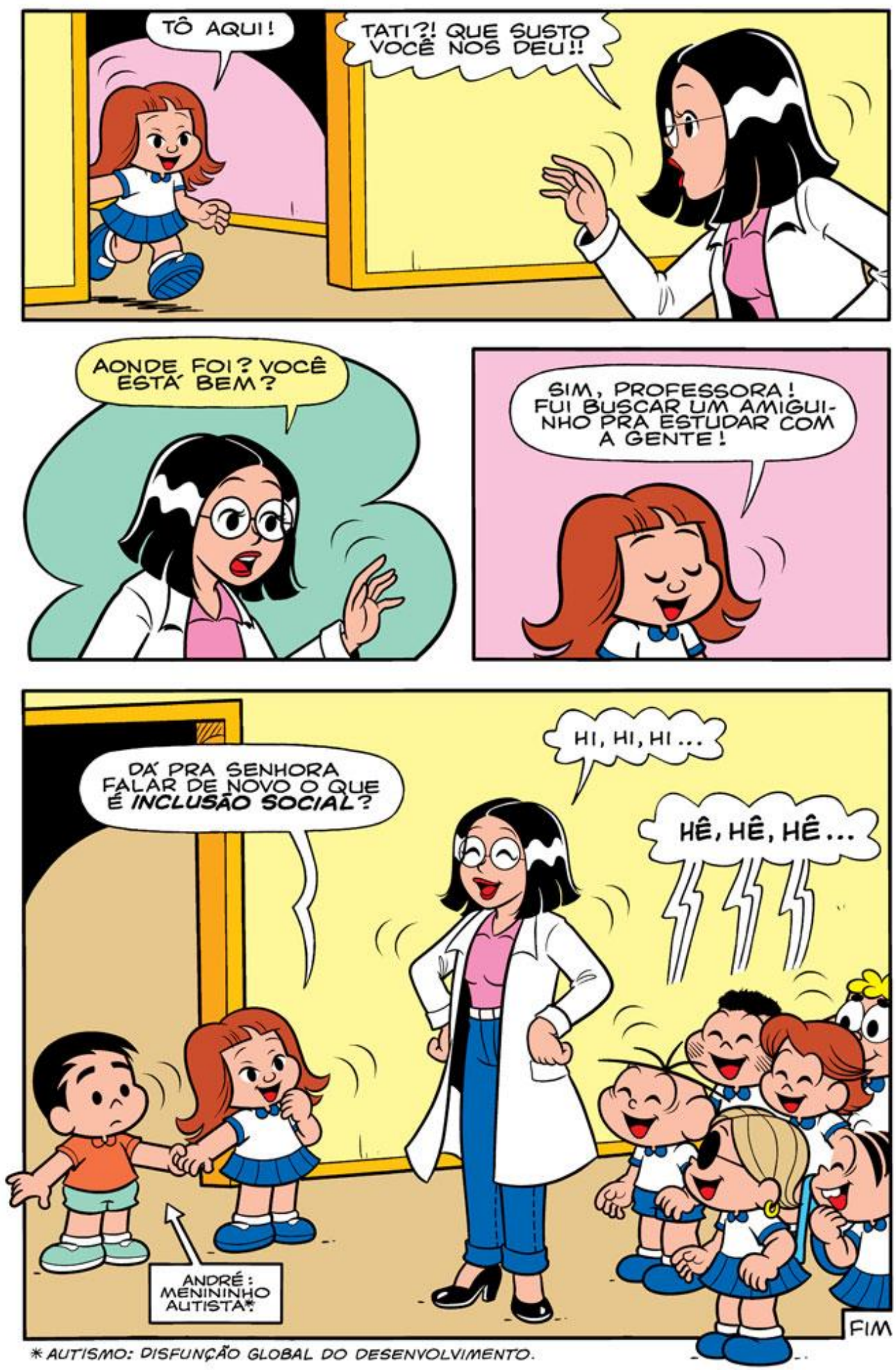

Disponível em: Acesso em: 14 de setembro de 2015. 